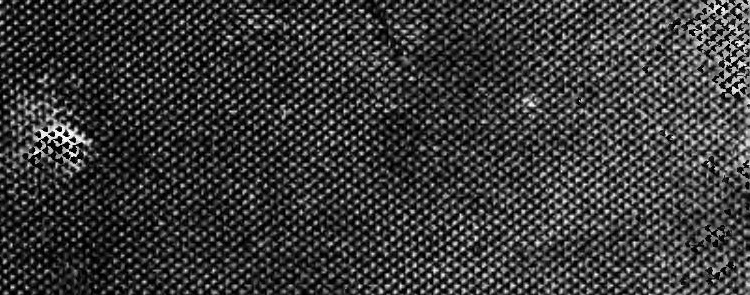

\% $8 \%$ \% $8 \%$

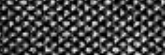

80

$$
\text { \% }
$$

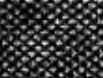




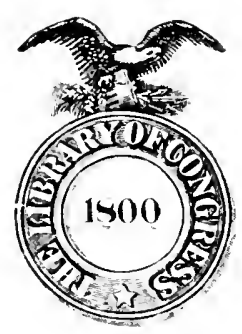

Class

Book

Copyright ג?

COYRIGIT DEPOSIT. 

THE INFLUENCE OF MONARCHS 


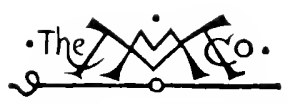

THE MACMILLAN COMPANY

NEW YORK - BOSTON - CHICAGO - DALLAS ATLANTA - SAN FRANCISCO

MAC.MILLAN \& CO., Limited

LONDON - BOMBAY - CALCUTIA MELBOLRNE

THE MACMILLAN CO. OF CANADA, LtD.

TORONTO 


\title{
THE
}

\section{INFLUENCE OF MONARCHS}

\author{
STEPS IN A NEW SCIENCE \\ OF HISTORY
}

\begin{abstract}
BY
FREDERICK ADAMS WOODS, M.D.

LECTERER IN BIOLOGY IN THE MASSACHCSETTS INSTITUTE OF TECHNOLOGY ; AUTHOR OF "MEXTAL ANI MORAL IIEREDITY IN ROYALTY"
\end{abstract}

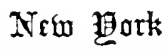 \\ THE MACMILLAN COMPANY \\ 1913 \\ All rights reserved
}


Coprpight, 1913 ,

BY THE MACILLAN COMPANY.

Set up and electrotyped. Published May, $\mathbf{1}_{9} \mathbf{1}_{3}$.

J. S. Cushing (n. - Berwick \& Smith Co. Nirwool. Mass., [..S.A. 
TO THE MEMORY

OF

MY MO'THER 



\section{PREFACE}

Is 1902, I brought together and rearranged, under a single interrelated group, the main historical statements concerning some three thousand members of royal and noble families, with the double purpose of measuring the force of heredity against circumstances, and of making a begimning in the systematic analysis of historical causation. The summary of that research was published in twelve papers under the title, "Mental and Moral Heredity in Royalty," which appeared in the Popular Science Monthly, August, 1902, to April, 1903, and afterwards (New York, H. Holt \& Co., 1906) in book form, somewhat amplified and reënforced.

The present volume is the first application of the methods of historical measurement (historiometry) to the larger questions of national growth and decline. It has long been recognized, in a general way, that many nations have had their eras of splendour and decay, but these transformations have never before been represented with definiteness and completeness. One could never place one's finger upon a specific date and say that about here the decline began in such and such a special feature, or that at another point a minor wave of progress rose upon a downward slope, or at some other point there was a pause in a general advance. For this reason, the mere tabulation of economic and political movements in modern Europe has a value of its own. This forms a line of departure from which journeys can be made into the more fascinating domain of historical causation; and whether such explorations do or do not meet their goal, discussions of this nature must always proceed from some such widely collected series of simple and easily verified facts.

Beginning from the tenth to the sixteenth centuries and carrying the study as far as the time of the French Revolution, there are two series of historical changes presented in this work. The 
first concerns itself with the snceessive alterations in the material conditions of the fourteen European countries which have been made the subject of comparative stuly; the second concerns itself with the personalities of the monarchs themselves; whose mental and moral charateristies are here summarized in brief. The history of these fonteen comtries furnishes 368 reigns or periods. These are matched against the personalities of the monarehs, and parallel columns are formed. Only very rarely has a nation progressed in its political and conomic aspects, save under the leadership of a strong sovereign. It is indeed strange that so plain and simple a truth has never been dwelt mpon before. There are, moreover, conent rasons for bulieving that the monarehs have, to a very larese cxtent, caused the ehanging conclitions and not the reverse - that the monarehs have been the product of the enviromment in which the y lived.

If the differences among the lings of history, whose varying types rance all the way from imberility to genius and from bestiality to heroism, are in their essence caused by qualities contained in, and carriol by, the germ-plasm from which they have been engendered; and if these differences among rnlers have been of such transcendent importance, then the master key of history is hereality.

That the genealogical methor shonil furnish the clew to the successful interpretation of listory is not at all surprising, since the genealogical interprotation is the only correct interpretation for natural history; i.e. all classifications of animals and plants are based $"$ prom descent. In the metagenesis of human affairs, neither herelity nor leersonality are everything, but they go so far towatis being everything that they may well be made the first forces to be measmed; and, as the extent of these ceaseless and ommipresent forces is apreciated, the presence of contrary forees can also be ascertainerl.

This, the second volume, has methods and aims, on the whole, different from the first: it loes not deal with precisely the same manches of royal genealogical trees, though some dynasties appear in both studies. This las given an opportunity to here ${ }^{1}$ See p. 196, 239, Chapter XVI. 
and there remould a personal characterization. Each of these researches has been made thoroughly inclusive as far as it has gone, with definite limits as to outlying dates. The outposts once fixed, every individual possible and every reign possible has been included in the judgments. Thus the first and most elementary necessity for the avoidance of self-deception is at once achieved; and to pick instances favourable to a preconceived theory becomes impossible. Whatever difficulties may lie ahead in the way of successful conviction, one chief difficulty is avoided. This error, arising from conscious or unconscious bias towards a personal a priori point of view, is, I believe, the principal reason why the philosophers of history have left no heritage to their successors and have thereby forfeited a general respect.

Even though the limits of time (the date outposts) are rigidly fixed and all instances are considered one after another in systematic succession, there still remains some danger of fallacy from bias. The interpreter may pervert each individual instance, and also he cannot escape the deviation from strict truth incidental to historical record, even in the sources themselves. But any scheme which is able to override a good portion of these difliculties can claim the name of science, since science is a relative term, and many of the so-called exact sciences are only approximations. Even the measurements of astronomy are only approximately correct, and the classification of organic species is being constantly shifted. The most exact natural seiences of to-day were once very inexact, but as soon as they began to show the spirit of science they deserved its name; and their early efforts, which to-dlay seem crude, are just as willingly given a place when the history of its development is reviewed. The present attempt to make history scientific, to fiml correlations, and to weigh causes, must he measured by what has preceled it; and, so measured, it will be found that no forerumner exists for which it can either feel envy, or from which it can receive aid. ${ }^{1}$

In the present volume, I have kept on the safe side by conceding to the opposed point of view the doubtful cases. In this way I have measured not so much the full influence of monarchs as 
their lower limit of influence. History at its best is teeming with minor errors. No method is needed to prove this; but any assertion that history is too full of error to lend itself to scientitic treatment is a gratuitous assmption unsupported by proof. The coördinated results of this rolume and of its earlier companion are themselves the proof that such an assertion is ill-founded, for if it were well-fomded, then orderly, reciprocal, and interlocking results could not be ohtained. What I have been able to get, I have got in spite of the errors of history : and the grasping of this principle, which is explained at length in the second chapter, is the sine gree nom of any intelligent criticism of the method I have called historiometry, and which I hope will more and more furnish a hetter-balanced judgment of historial values. Sociology, psychology, and eugenies, as well as ecommics and political seience, need all the aid they can gret from that long-established laboratory of experimental polution known as hman life, and that aceount of individual and national experience known as history.

FREDERICK ADAMS WUOBS.

Brookline, Miseichisetts.

February, 1913. 


\section{CONTENTS}

\section{CHAPTER I}

\section{INTRODUCTGRY}

Need of a new interpretation of history - The problem stated The relative importance of "great men" as factors in history Need of new methods - Methods here used for eolleeting the evidence-Seope of the work - The intluence of individual monarchs - The signiticance of regencies and minorities.

\section{CHAPTER II}

Pinlosopiy of IIstory aye llistomionetry . . . . .

Failures of the philosophers of history - $\mathrm{N} \mathrm{e}^{2} \mathrm{w}$ methol needed - Measurements in anthropulogy and psychology-Central idea of historionctry - Errors in history, random and otherwiseRandom errors nay, under some cireumstanees, be innored - Fxamples from " Heredity in Ruyalty," and from the eity birth of notable Amerieans - A paradox in historionetry - The need for aecuracy in historical details - Dogmatic opinion permissible in historieal details - Also for the evaluation of traits of character and condition of countries - For the interpretation of causes, methods of proof must be derised.

\section{CIIAPTER III}

France. A Scimanizen History . . . . . . . . . . 37

\section{CHAPTER IV}

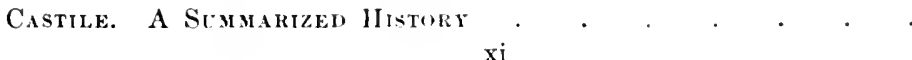




\section{CIIAPTER V}

Aragon A summarized History

$$
\text { ('HATTER VI }
$$

United Spain. A Stmarizei, History

\section{CIHAPTER VII}

Portugal. A Scmmakized hintury . . . . . . . . 87

('HAYTER VIII

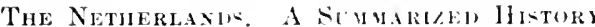

('HAP'TER IX

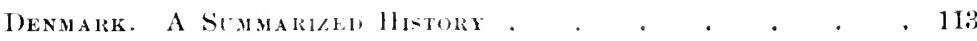

$$
\text { CHAPTER } x
$$

Swedex, A simuarizel, hletory . . . . . . . I23

\section{CHAPTER XI}

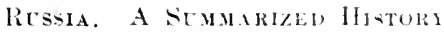

189

CHAPTER XII

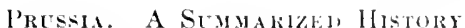

CIIAPTER XIH

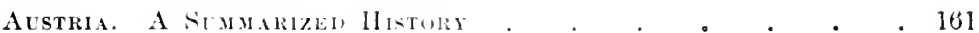

CHAPTER XIV

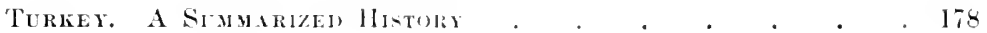

CHAPTER IV

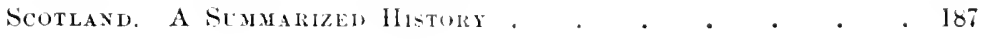

CHAPTER XVI

ENGLaNd, A ScMMARIZED Hiotolix . . . . . . . 196 


\section{CHAPTER XVII}

Interpretition of the Results.

The parallelism between rulers and the condition of their countries - This correlation is very high except in modern Fngland Three arguments which prove that the rulers influenced the conditions, and not vice vers $a$ : (1) Suddenness of the changes; (2) The evidence from minorities ; (3) The evidence from the pedigrees Natural ability of royalty compared with other social classes Eight reasons for believing their natural ability to be high - General and special characteristics of royalty - Sovereigns reputed chaste and not cruel were common even in the earlier ages - Such contrasted types are expected from modern views regarding heredity - The a priori point of view and the way the facts fit into it The question of false bias - Reasons for holding this error slight :

(1) Early, compared to later history ; (2) Nations much studied, compared with those but little studied; (3) Estimates have been but rarely reversed; (4) Perhaps as often raised as lowered; (5) General survey of the whole distribution of the material - Definition of the "gametic interpretation of history" - Hereditary influences (gametic) can be separated from environmental, by making the problem a problem of differences.

\section{CHAPTER XVIII}

\section{Cacsation in Histort.}

Prussia in the seventeenth and eighteenth centuries an example for the study of causation - Some ifs in history are pertinent, others not - Complexity of history and the question of unravelling causes - "Method of differences" may be tried - The time element in history is helpful - The "great-man" view of history Graphic curves to represent class differences - Five conditions which lead to the form of curre typical of the monarchies of antiquity - Modern dynasties formed in the same way - These five forces are working at the present day towards the production of castes and an aristocracy of wealth.

Appendix (1) Bibliography and Grading . . . . . . 305

Appendix (2) A New Name for a New Science. . . . 404

Appendix (3) Historiometry as an Exact Science . . . . 407 



\section{THE INFLUENCE OF MONARCHS}

\section{CHAPTER I}

\section{INTRODUCTORY}

No subject of speculation lies more in odium, confusion, and neglect than the philosophy of history, and yet no questions arouse more heated discussion than those concerning the causes of human action or the reasons for a nation's fate. Here every one speaks with the utmost assurance; and the same man who would contend that the record of history is unique, and that the human drama has been too complicated ever to be interpreted into a science, is the first to advance his cause as the cause, and the last to see the many alternatives which indeed do inhere, and are the warp and woof of its complexity.

It is more than two thousand years since the saying "The proper study of mankind is man" was accepted as a safe remark, and in its passage through the ages this oft-quoted phrase has not been seriously contradicted. If, then, man is apparently interested in his own welfare beyond the concrete needs of the hour, and does for some reason crave a rational account of why some succeed and others fail, he will always in some way turn to the records of the past. Even if his desires be entirely utilitarian, he cannot avoid it. His knowledge of the past may not be more than the records written in his own brain, impressions of his contact with his fellowmen, they may not be reënforced by memories of what he has read beyond the vague impressions gained from the daily press, yet in the formation of his judgments he has used the human record. He has been obliged to weigh probabilities 
and not certainties, and measure men in terms of a standard which has come to him as the composite resultant of his worldly wisdom. If, then, man takes recourse nolens volens to records of the past, how much more wisely in the game of life the play must unfold under the hand of the person who remembers what he has read as well as what he has seen; and if to the usual reading of history and biography, some scheme can be devised which can compel that printed record to divulge even a fraction of its deeper meanings, then by so much the knowledge of mankind, for mankind, will progress.

There is a fascinating interest in explaining the decline of the great civilizations of the past, and there is always much that is superficial in such explanations, from the failure to take into account causes of growth which acted prior to the beginning of the decline - factors which were at one time present but were afterwards withdrawn; and no factor of such a character is more important than the dynastic factor, and indeed the whole aristocratic element of which royalty is but the top and crown. Because Egypt, Greece, Rome, the Italian cities, Spain, and Portugal all declined, there is no reason why other nations should follow in the same track. The new western nations may be built upon entirely different foundations; they may have been evolved in such a way that great masses of people have become elevated, and able to govern themselves, whereas the earlier civilizations may have been dependent for their life and growth on a very few people, who formed an aristocratic class far superior to the masses whom they governed. A knowledge of the relative intellectual differences between royalty, nobility, and commoners becomes, therefore, a desideratum for each nation and each age. The present research makes a beginning towards such an appreciation of class differences.

No historian will deny that monarchs have had at least some importance in moulding the course of ancient, mediæval, and modern history. No complicated and exhaustive research like the present is needed to arrive at an agreement on this 
point. But as soon as one asks, how much, when, and where, the answers can be given only by systematic comparisons and quantitative tests. There are several reasons why an accurate knowledge of the personal influence of sovereigns is among the first desiderata in a true science of historical interpretation, and not the least significant among these reasons is the fact that in some countries, and especially within modern times, this factor becomes reduced to a minimum. By indicating all the points at which regal influence has been at its maximum, one at the same time marks out those periods when the same factor has had little importance, and these periods, once isolated, may well become the objects of further investigation. One can then see if these democratic or anti-monarchical periods have elements common to all, or if they can be in any way classified or better understood.

If the monarchs themselves have had great weight in directing the course of history, how did they get this importance, how did they utilize it, how and when did they lose it? These become historical questions of unsurpassed interest. The present book will have something to say as to the first and last of these queries, the origin and decline of royal power, but its chief concern will be to describe the uses which these privileged persons have made of their exceptional positions, or, more exactly, the personal influences of monarchs on political and economic history.

This research will be almost entirely objective and will at the start make no assumptions whatever, unless it be an assumption that a book is a book and a printed word is a printed word. It is important to note that I do not assume that any book tells the truth or that any statement is correct. While a statement in a book of history need not be a fact, it is at least a fact that the book says so, and it is with such facts that I begin. In collecting the printed statements of history I am just as much dealing with objectivity and reality as if I were picking up pebbles on a beach. I have made a rearrangement of historical statements under a new classification, 
and am ready to show that when such a rearrangement is made, then certain conclusions follow as the most probable interpretation of the observations.

The next step in the process will be readily granted. Whatever one may think of kings as a whole, some kings have certainly been more able than others. It is also a fact that the amount of admiration shown by historians for the intellectuality of some kings is greater than for others. It is also a fact that some periods of national history are more generally recognized as progressive than others. We are, therefore, justified in attempting to express these differences by means of common methods of classification. Of all methods of classification the threefold is the commonest and the most promising. We do not commonly find that men are either good or bad, or all men can be divided into two classes, the successful and the unsuccessful. What we do see on every hand is that out of large groups, some few stand out as distinctly superior, some few as distinctly deficient, and between the two a mediocre class which blends gradually into the two extremes. If any large group of kings be divided into three classes, and the names pigeonholed as superior, inferior, and doubtful (according to reputed ability) a fair proportion will fall inevitably into the superior or inevitably into the inferior category, no matter who makes the classification. The point is that, comparing them with each other, some must go in these extreme classes, as there are sure to be some who stand out from the average. The middle grade may then be reserved for those who do not easily fall into one of the two extreme classes.

Following the threefold method, I have graded each ruler in one of three classes except where information has seemed too meagre. The symbols +, "plus"; t, "plus or minus"; and -, "minus," are placed at the left of each name in the tables found in the Appendix." They refer to three

1 Occasionally a doubt is expressed by the use of two symbols ( \pm , or + ) $( \pm$, or -$)$. 
grades of rating for intellectual qualities. Moral traits are, as far as possible, left out of consideration while making up the classification for intellect. The reader may wonder if it is possible sharply to separate intellectual from moral attributes. Without going into the psychology of the question, and conceding that there is a border line in which these two commonly employed terms blend and become indistinguishable, it is nevertheless undeniable that for every day purposes we all do classify and distinguish between goodness and brilliancy, wickedness and stupidity. Experience proves that it is usually easy to place adjectives qualifying psychic differences either into the class called mental or the class called moral. By looking over the summaries for the characteristics of rulers, one can see that only a few of the adjectives employed fail to fit one or the other of these arbitrary psychic categories. The words courage, bravery, and perseverance seem to divide their significance. I have let these words carry a partial weight.

I have not followed any mechanical or objective scheme in weighing the value of adjectives, not because of any inherent difficulty, ${ }^{1}$ but simply because it is not necessary for the purposes of my conclusions. Indeed, even by the dictates of strict science I am not beholden to describe any part of the method by which I have obtained these summaries under the parallel columns "Ruler" and "Condition of Country." These tabular columns are formed of 736 elements or miniature histories. Three hundred and sixty-eight of these are descriptions of the chief economic and political changes during the years of 368 different monarchs, regents, or other rulers, royal or non-royal. The 368 elements which form the left-hand columns are my own descriptions of the traits of character of the rulers, formed, it is true, out of materials collected in a systematic way, but presentable as they stand, without the need of further justification. It is only necessary that each of these scparate elements (condition of

${ }^{1}$ See Appendix (3). " Historiometry as an Exact Science." 
country and characteristics of ruler) shall be sufficiently accurate to be assigned rightly to its proper grade. As there are only three grades, and the doubtful cases are allotted in a way to give the benefit of the doubt to an opponent of the conclusions, my position in the matter is a very safe one, and the asisinment of grades becomes very easy. That is, on presenting the elements, with their grade-symbols attached, I am realy to ask - who will challenge more than a very small pere cent of these assigmments? If most of the elements go mobliblenged and are acepted, then any conchusion afterwards male must be accopted, providing the subsequent reasoming be correct. That is to say, I start fresh, from a new position.

This is one way of developing the thesis. Those qualified as sperialists on the history of the various countries will, I hope, pass as sufferently farourable verdict upon the judgments I have made, to allow the dat a to serve as a basis for the antplifiation. The unfarourable eritic must remember that it is not sufficiont to indicate places where my own judgments fail to corresponel to his own historieal opinions. Ho must, if he discrestits the value of the rescarch as a whole, show that the orrors which I have made tend falsely and improperly to farour subsequent conclusions. If, for instanee, a ruler whom I have graded as "minus" is in his opinion "plus," unless tho erade-symbol which I have made for the "conditions" is also minus, it would not lessen the weight of my conclusions if the smmbol mark for the ruler were changed. Suppose the "ronditions" were "plus," then it would actually strengthen my conelusion to raise the grading of the ruler. If the conditions we t, "plus or minus," then it would not make any difference one way or the other whether the ruler were in grade "minus" or grade "plus," as each of the extreme grades is at an rqual distance from the medium grade. So, from the standpoint of strict logic, I might hold myself entirely aloof from mentioning any authorities, and say: These statements about historical characters and 
historical events are so well known and agreed upon that any justification is unnecessary, or even if they are not entirely so, the remark applies to a sufficiently large percentage of the statements, and I will rest on this.

It may be worth while, however, for some purposes to give an account of the method used in making up the gracles and tabulations. Such details have a technical interest and may be serviceable later on. It has been my aim to rely on the usual or standard authorities, - histories which are well known and cover a considerable portion of the life of the nation. These are perhaps just as uscoful and reliable in this particular research as a large collection of special monographs. I have purposely omited biographies of individual sovereigns and special works on short periods, because, first it would take a much longer time to complete such a research, and even then it is a question if the advantages would outweigh the disadvantages. It is presumable that special histories are more correct in recording facts and details, but it is not likely that the historian who has dealt with only a short period of time or with the bjography of a single ruler will have as good judgment of comparative values - changes in national welfare, or degrees of clifference among royalty - as one whose field has been more extensive.

Some might suppose that in looking up material of this sort, biographical, political, and economic, one would find many disagreements in expressions of opinion, but this is not so. Historians may and do disagree upon minor points, but not often upon essentials. This is one of the facts that I have already found to be certainly true as regards individuals, and the whole material of this work shows that this statement is equally true for political and economic conditions.

Sometimes the more detailed histories have also been consulted and according to the following plan. Usually

1 For evidence that encyclopxdias agree with high authorities, see page 407 of Appendix. 
such specialized works are unnecessary. A sufficiently clear idea can be gained at once as to the intellectual rank of the sovereign and the tendencies of his reign even from the most generalized aceounts. The eneyclopedias alone contain sufficient data to fix the extreme examples - those which deviate the widest from the loubtful or median grades. For instance, if only three grades are employed, no detailed reading is needed to decide the intellectual grades for Frederick the Great or Peter the Great, or, as an antithesis for Charles II of Spain, or for the eonditions during the reigns of these monarchs; and so on from the extreme deviations toward mediocrity where the decision becomes more difficult. It is not necessary to go to specialized sources in cases like Frederick the Groat and Peter the Great; ${ }^{1}$ no amount of subsequent reading would remove them from the "plus" grade for mentality. They might be shifted up or down within the grade, but surh would not affect this research. The rulers and reigns that deviate far from the mean are fortunately easy to place; they are also fortunately the ones which affect the weight of the conclusions most; just as any weight on a halancing beam tends to tip the beam more, the farther out it is from the centre. If the grading of the ruler and the crading of the conditions cannot be satisfactorily decided upon at once, then one naturally looks to more specialized sources. A considerable number will even then not be assignable with precision, but these will

IEven the epithets, which hy popular consent have been attached to the names of sovereigns, are not often misleading summations of their eharacter. We may find a John "the Good" of France really bad, or a Ferdinand "the Saint" to have won encomiun through extravagant patronage of the church; there are exceptions, of course, but far more often than otherwise these adjectives seem to give as gord a picture of their traits as it would be easy to concentrate in a single word. In the confusion of genealogical nomenclature and the balel lists of dynasties, it is helpful to the eye and memory to find Bayezid "the Thunderbolt" and Alfonso "the Noble," Peter "the Cruel" and Martin "the Humane," Charles "the simple" and Frederick "the Great." I shall make use of these terms, but will note whenever they appear incongruous or confliet with the estimates of modern scholars. 
affect the conclusions least, owing to their median position in the scale, and, as before stated, they are so placed as to weaken the conclusion to which I have come.

The bibliographies printed in the Appendix are made up of such works of reference as one secs mentioned at the close of the special articles in the standard English, French, and German encyclopædias. These articles on the history of European countries are signed articles written by wellknown scholars and ought, therefore, to be valuable as a starting-point, not only for their references, but also for their own statements of fact and judgment. Under the condensed summaries in the Appendix the letters A, B, C, D, etc., ${ }^{1}$ refer back by volume and page to the books that have been consulted.

It may be noticed that some of the authorities are either out of date or notoriously partial. Such criticism might be direeted against Dunham, Coxe, or Motley, but I have not used these when their statements conflict with others. The great majority of the historians relied upon are modern, and have the reputation of being impartial. Even if their impartiality be questioned, the general effect of their partialities would not lead me to a spurious conclusion unless they tend in one direction. This possibility will be reconsidered in the next chapter.

The history which I am analyzing concerns itself almost entirely with political or economic affairs, - the side of history which may be called material, in contradistinction to the spiritual or intellectual. Although it is not possible, from one point of view, to separate these two factors in history, it is nevertheless easy, in practice, to place under the term "material affairs" all changes which have to do with certain stated features of national life.

${ }^{1}$ In the choice of authorities I have also been aided by the personal advice of a number of historians, whose special knowledge in their various fields has made their suggestions very helpful. The order in which these works are arranged $-\mathrm{A}, \mathrm{B}, \mathrm{C}, \mathrm{D}$, etc. - is not intended to have any signifieance. 
This research will note all the important statements on the following topias: finances, army, navy, commerce, agriculture, manufacture, public building, territorial changes, rondition of law and order, general condition of the people as a whole, growth and decline of political liberty, and the diplomatic position of the nation, or its prestige when viewed internationally. No attempt is made to include literary, educational, scoentifice or artistic activities. The monarehs as patrons, doubtless, wore not uninfluential here, and also it would be interesting to compare eras of intellectual and artistic growth with political and material inplendor, especially as many bedicre in the influence of the lat ter upon the development of higher culture. Such a researeh is alreacly hatf completed, if the politice-ceonomic tabulation which I here present be sufficiontly correcet.

The question of political liberty and how far this is to be considered a matrial and how far a spiritual advantage, sometimes, though mot often, enters in a way to ratue perplexity. Ono frepuently finds that undor strong kings the country flourisbed in almost ary way oxerpt that the people wore opperesced. It is naturally difficult to woigh the value of political and porsonal liberty against prosperity in commercial, inclustrial, or other materialistic affars; but the quostion which I am doaling with is as far as possible the economic or material sicle apart from the intellectual or cthical. Noarly all the statements in history are found to fall naturally into one or the other of the two classifications, materialistic or idcalistic. It is just the same in dealing with the traits of an inclivichal. Most asperts fall naturally to either the intellectual site or the moral side. Some few, like courage or perseverance, might well be thought to belong to both. It would not he a had first approximation to divide in halves these middling attributes. In any erent a certain amount of individual judgment or personal equation is unaroilable, or is perhaps even advantageous, in work of this sort. If I have succeeded in eliminating by 
my methods a great mass of preconceived notions and $a$ priori dogmatisms, I shall not be disturbed if a few are found to remain.

It is better to divide the intellectual, moral, and artistic conditions from the materialistic and correlate them separately with monarchs, or with whatever series one wishes, than it is to mix all the national conditions together. Sometimes one set of conditions is "minus," and the other is "plus," and so they would confuse each other, and mask a corrclation which might be truly present. For instance, the literary and scientific conditions are "plus" for the reign of Alfonso X of Castile (1252-12St), while the material conditions are "minus." Both are highly associated with the strength and woakness of this monareh, who was scholarly, though unpractical. Even as it stands there is at times a masking of true correlation by putting all the "material" conditions together; as, for example, when the nation is successful in warfare, though declining internally (financially and otherwise) under the loalership of a warlike sovereign who is both brilliant and reckless. Therefore, as far as this source of error is concernel, the real parallelism is higher than I have found it, and would be proved higher if the separate factors which fall under the general heading "material conditions" were each correlated separately with the peculiarities of the rulers.

Sometimes the activities of one king were not realized during his own reign and beeame manifest only during that of his suecessor. Sometimes a country has been devastated by uncontrollable forees of nature, earthquakes, famines, or plagues. The general effect of all such chance happenings is, of course, to reduce still further the parallelisms which have been found in spite of all sueh happenings.

There is one souree of error which would work in the opposite direction. Sinee it would illegitimately raise the correlation and so lead to an overestimate of the influence of monarchs, a consideration of its probable magnitude 
becomes of the first importance. This arises from the possibility that historians, especially the earlier historians, the chroniclers, and contemporary writers were wont to panegyrize such kings as were fortunate, or ruled when the conditions were favourable, and at the same time unjustly condemned those who, through no fault of their own, suffered reverses or lost their crowns. The answering of this objection is a long story. Its importance will be constantly kept in mind, and the arguments reunited in Chapter XVII, where the whole question is gone into in detail. I need only say, for the present, that this source of error is shown to be slight when viewed in its bearing on the entirety of this research. It is not a general danger associated with the entire research, but is rather a special danger eoexisting with certain specific periods.

Fourteen national histories in all are analyzed in this volume. Most of the aceounts cover a period of about five hundred years; and for some of the countries, England, France, Spain, and Portugal, it has been found feasible to extend the study into earlier centuries, so that about eight hundred years can be given. Each account begins at as early a date as the exigencies of the case permit, the special reasons for which are given at the beginning of each chapter, and eloses with the reign approximating the French Revolution and the last part of the eighteenth century. Thus the anterior and posterior date limits are systematically fixed.

The territorial outlines include all the lands actually under the monarch in question, except occasionally when the territories are too much separated geographically to be treated as one country. These fourteen countries cover the greater portion of the map of Europe as it is to-day. They are representative of various races and climatic surroundings. They are, in general, the nations that have succeeded in maintaining their entities, being on the whole successful politically, having grown at the expense of surrounding areas. For this reason more "plus" periods are found than 
would be the case if one studied the areas which, from the international political standpoint, have disintegrated and diminished in importance.

The monarehs themselves are not representative of the stock of the nation over which they happen to rule. They are, from the standpoint of race, an international breed, and (with the exception of the house of Osman, which still rules in Turkey) an interrelated and biologically segregated group of persons of ultimate Germanie-Scandinavian origin.

In addition to the monarchs themselves, the personal influence of prime ministers and other leading statesmen is naturally an important question, and while I have not laboured with the same definiteness to eorrelate their personalities with national political and economic conditions, I have nevertheless noted in each country these non-royal leaders, and their entrances and exits, historical distribution, and presumable effects on national ehanges, and I do not hesitate to suggest that they constitute a force second only in importance to the monarchs themselves. These nonroyal rulers appear upon the scene frequently during the minorities of sovereigns. Frequently, also, a far-seeing sovereign appoints a great statesman to a post of extreme leadership. How frequent, when and where, is a question, and this will be answered in the course of the text as well as summarized among the conclusions.

When a regeney is in non-royal hands, - whether under a single regent or divided in form of a couneil, - I shall treat the period as if it were a period in which the monarchs were "minus," that is, absent or weak. If the conditions are favourable or "plus" when the monarehical rule is absent, it counts so much against the influence of monarchs. If disaster and decline set in under non-royal rule, then there is that amount of indication that monarehical rule was needed. It is sometimes difficult to say just when a minority ends and when the debit and credit aceount should be taken out in the name of the young king himself. I have frequently 
taken this at the date when the king reached the age of twenty-one, but very often the youthful sovereign has been in actual and practical control of affairs, and indeed making revolutionary changes, much earlier than this age, so that each case must be treated on its own merits.

In a way similar to a minority, there is another form of government, which lends important aid in unravelling complicated questions. This is the existence of an interregnum. These definite interludes have much of the experimental method about them, and although some of the debatable questions of history are neessiarily interwoven, they are especially valuable because of the undehatable material which they contain. An interregnum has a definite beginning and end, and, the royal authority being completely withdrawn, this influence becomes for a time nil. The amounts and kinds of progresis made during minerities and interregna, their distribution in place and time, are among the most instructive of the tabulated facts, and an inquiry into the causes of the same serves to throw light on several other historiological problems not directly involved. Many points like this have been taken advantage of in developing the conclusions. The mothods of historiometry differ so fundamentally from the older "philosophies of history" that it will be necessary to give considerable account both of the history of historical speculation and of the ideas and aims of the newer science. 


\section{CHAPTER II}

\section{PHILOSOPHY OF HISTORY AND HISTORIOMETRY}

THE present indifference to any systematic outlook on history is not hard to understand. Although the most brilliant and gifted minds have worked in the field of historical interpretation, it is not surprising that little advance has been made. The famous ehampions lie well in the past. They could hardly have been expected to have any clear coneeption of human development if they lived and died before the days of Darwin, Wallace, and Spencer. Evolution in some form was, it is true, already the conviction of nearly every great thinker from Thales to Goethe. They guessed at the continuity from general considerations, but they did not know it until the naturalists proved it; and, furthermore, the ideas of natural selection, survival of the fittest, heredity, and modification from the environment were practieally non-existent, or at least not utilizable as they are to-day.

Not only did the pre-Darwinian philosophers of history lack assuranee for the correct genetic point of view in regard to the development of human society, but, more baneful still, their systems were developed in a way to give free rein to the most rampant theories. Never once did the preconvinced, if earnest and erudite, apostles of historico-political doctrinaires devise any check to curb their waywardness, or recognize the dangers of the personal equation. The result has been that the well-known writers who have attempted to interpret historical meaning are always found unconvincing. They have been one-sided in their devotions, or narrow in their scope, and always deficient in scientific method. The partisanship of each famous writer is so evident that it is 
worth while to go over a list of the leading philosophers of history very quickly, and show that each ean be associated at once with some particular presumption.

It is unnecessary to begin as early as the ancients. Neither the Greeks nor the Romans regarded history as a subject for special philosophy. Political science and political experience occupied much of their attention, and here they were the great pioneers; but the world had then but a brief historical past to look to, and was not much interested in gazing backward. Perhaps the earliest contribution to the philosophy of history is the "De Civitate Dei" of Saint Augustine. It reeognizes historical unity and the progress of mankind, but it subordinates all things to the Church, is essentially a theological discourse, and ignores secular eulture and the ordinary human interests.

It was more than nine hundred years after the death of the great Latin father before another considerable attempt was made to interpret the record of the past. Ibn Khaldinn, the Arab historian, wrote during the last part of the fourteenth century a so-called "Eniversal History," the first volume of which (Muquaddama, or preface) is devoted to discussion of causation. Although the Arab race has produced few original thinkers, the Muquaddama, whatever its defects may be, is certainly an original work. Ibn Khaldūn was the first to treat history as a proper object of a special science, and, considering the age in which he lived, the Arabic philosopher was indeed remarkable in the depth and keenness of his observations and in his numerous anticipations of modern theories. By him we first hear sounded the wellknown themes, taken up by Montesquieu, Draper, Buckle, and scores of others, - a nation's life is like the life of an individual, with youth, maturity, and decay; a civilization is determined by its geographic, climatic, and personal entourage. Soil, rivers, moisture, mountains, desert, seas, all come in as factors in his reckoning, nor are the psychological causes entirely overlooked, - luxury and town-life 
enervate the native vigour of nomad tribes. Adequate proofs of cause and effect are of course lacking, but the mere suggestion of so many naturalistic factors in civilization was a wonderful thing in itself ; and, more than this, Ibn Khaldūn appears to have been the first historian to appreciate, not only human adaptation, but also progress, - he went far beyond any of the Christian chroniclers of the Middle Ages; they were quite unconscious that history had been unfolding successive stages of development. Ibn Khaldūn was the earliest devotee of what may be called the "environmental" school of historical philosophers. He had, of course, no idea of the force of heredity, or of natural selection, sexual selection, or many other intermal causes recognized to-day as important factors in the rise and fall of nations.

Bodin (1530-1596) and Montesquieu (1689-1755) show much the same bias. Vico (1668-1744), great in his understanding of the evolution of Roman law, put into history his own law, the "law of eycles," and then forced facts to conform. Bossuet wrote around a theological centrum, and his eye never wandered far from the focus. Rousseau made a paradox of history and did not even recognize the truth of the general progress of humanity. He, more than any of the others, excelled in the arts of the speeial pleader, and whatever service this eccentric genius may have rendered the cause of liberty, his effect on the philosophy of history was to introduce even greater confusion.

Hegel, with his universal interests and own theory of the universe, plunged into history, but not until he had already developed his philosophical system. Hegel reduced everything to his formula "the development of the Idee." His "Philosophy of History" is his most popular work, has been much translated and recently reprinted as part of a popular science series, in English. It is unsatisfactory to historians, not on account of its metaphysical point of view, but because so many of its chief subsidiary theories are in defiance of the facts of history. For instance, according to Hegel, man in 
his primitive condition lived in the mountainous regions of the globe, next in the plains and valleys, lastly by the coasts and mouths of rivers. The first form of government which we see in history is Despotism, the second Democracy and Aristocracy, the third Monarchy. All-powerful is "the spirit of the age." The Great Man is merely its incarnation. Hegel has no place for the opposite view, - that the Great Man may be the accidental resultant of favourable inherent qualities and himself the moulder of his age.

Frederick von Schlegel also wrote from the metaphysical point of view. Man was created free, - two courses lay before him, upward towards God or "downward to the abyss." The "Lectures on the Philosophy of History," first published in 1829 , still maintain a certain popularity and are included in Bohn's Standard Library; but they show the same general fault of all philosophies of history, written from a premeditated position. Schlegel's desire is to glorify the Catholic Church. He was opposed to principles of political and religious freedom.

Auguste Comte, from an entirely different though equally a priori conception, tried to make the statements of history fit his theory of the law of the Three States. The earliest or most primitive stage of human evolution was the Theological, next came the Metaphysical, and finally the Positive or scientific. Whether his generalization be true or not when viewed in its widest interpretation, it is certain that Comte strained the facts of history in his handling, and was partial in the selection of only such materials as attracted his eye and would decorate a handiwork to which he had pledged his life's devotion. Scientific knowledge has advanced since man dwelt in the sarage state, and seemingly at the expense of Theology and Metaphysics. Comte did not realize that the sources of Theology and Metaphysics are infinite, and their reservoirs feel not the loss. Take something from infinity and infinity remains. Theology and Metaphysics continually expand anew from higher and higher levels. 
This depreciation of religious and spiritual forces is generally considered a primary defect in the writings of Buckle. From the biological standpoint his theory of history is very one-sided. Environment is extolled and heredity decried. Moral forces, so neglected by Comte and Buckle, became for Droysen the one important consideration. "Historical things have their truth in the moral foree, as natural things have theirs in natural laws. Historical things are the perpetual actualization of these moral forces. To think historically means to see their truth in the actualities resulting from that moral energy." 1

The names of many other less notable philosophers of history might be eited, and it would be easy to show that they, like their more famous brethren, generally can be at once associated with some particular theory. More often than otherwise, their writings are biased, usually notoriously so, but even when their views are many-sided and their discrimination is fine, as with Guizot and Turgot, no method is taken to insure objectivity. The interpretations, excellent as they may seem to one reader, may not suit another reader, for the very fact that they do not stress that particular reader's private fancy, and so even here again, all go out the same door where they went in, and nothing permanent is gained.

All these considerations make it increasingly elear that a new method is needed in historical interpretation, one that shall make the investigator able in some way to take cognizanee of contrary forces and contrary explanations at the same time that he is testing his own working hypothesis. The business of science is to get eoncerted agreement. About the only ideas on which the great majority of historical philosophers may be said to agree, are the ideas of progress, of humanity, and of freedom. ${ }^{2}$ The last two are embodied in the first, so that there is not much more agreed upon by his-

1 "Outline of the Principles of History," Boston, 1893, p. 16.

2I am indebted to Flint's "History of the Philosophy of History," for much of the above concerning the particular beliefs of various writers. 
torians than the general conception that somehow, and on the whole, there has been a progress, an increase of the store of human knowledge and an adrance to more complex levels of what we call eivilization. The economic interpretation, the geographical, the anthropo-geographical, the Kultur geschichte, the individualistic, the political and the ideologieal are all current. It is not advancing very far or a proof of any great discernment to adopt the view of the "autonomie" or sociologieal school and sec that there is some truth in each of these one-sided interpretations. Of course there is something to be said for each set of opinions. The question is, how much?

The method I propose has for its chief aim just this quantitative valuation. We have had enough of idle argument, of a priori dogmatism, of free generalizations from half-truths and eternally conflicting conclusions. The time is now ripe for the introduction into the study of history of the methods which have so much improved the conditions of human life through advancing the scienees of physics, chemistry, electricity, medicine, and public hygiene, - inductive methods, methods of the laboratory, methods of experimentation. No objection can be raised, because you cannot set up governments merely in order to see how well they work, or place races in new surroundings, or control the breeding of man as man controls the breeling of domestic animals. All objections of this sort are swept away by the simple reply: the experiments have been performed. History is their record.

It is estimated that 400,000 books have been written on the subject of human history. All, or the greater part of these writings, have been read and re-read, culled over, rearranged, eritieised, and utilized by other historians, and the whole concentrated into text-books, standard histories, and encyclopædias. This great mass of knowledge may be likened to a pyramid in which the sources lie at the base; and the few books that are often read by many people (not the merely popular but the standard and authoritative works) 
lie somewhere towards the apex. Their statements are drawn from the material which lies beneath. They are fewer in number and their material is more concentrated. Resting upon these standard works and taking support from the broad nether strueture lie the most concentrated of all, the brief historical articles written by the special experts and bound up with other quintessential matter in the modern encyelopædias. Can it be that all this information is useless, that there is no lesson to be learned except the bare narrative, no prime causes to be demonstrated as more important than other eauses in determining the destinies of nations?

Considering the importance of the subject and the great advances made by objective investigations in the organic and inorganic sciences, it is not only high time that a beginning be made, but there are many reasons for thinking that now and only now all things favour a successful issue. After the theory of evolution became established and the excitement of the fray had dwindled on the great primary problem, there still remained the question how evolution had taken place, and questions centring around modes and manners of inheritance. This led to the introduction of new methods as an adjunct to mere observation, the propounding of numerieal laws governing heredity, and the bringing over into psychology, and sociology, as well as biology, of systems of grades and measurements.

Quetlet was the first to apply on a large scale quantitative expression to human attributes. He worked from 1823 onward. Galton took up the idea and developed it further, and especially applied it to heredity and eugenies. The total number of investigators who in one way or another have used methods of measurement in psychology and biology is certainly in the hundreds if not in the thousands; but it is only since about 1895 that this movement has been well under way. The recentness of this development is one explanation why no attempt has so far been made to quantitate historical movements. A very few (not more than a dozen 
persons at most) have made some more or less objective analysis of groups of persons mentioned in history, chiefly historical celebrities with the idea of discovering the qualities of such men and explaining the origin and psychology of genius. These researches have not as yet been applied to historical eriticism or historical interpretation, but their results are valuable as a line of departure in this direction. In the issue of Science for November 19, 1909, under the title of "A New Name for a New Seience," I published a brief bibliography of such rescarches and proposed the term historiometry for the same, i.e., any researches in which the statements of history have been subjected to some more or less objective method of measurement. In some of these researches the personal bias of the investigator is slight or negligible. In others the personal equation is higher, but all aim at proving something by means of counting historical instances pro and con. The advance which these scientifieally inclined writers have made over all carlier interpreters lies in the counting of the cons. But all this objectivity does not necessarily mean the attainment of even roughly satisfactory truth or the conviction of the properly critical. The criticism is at once raised that unless we can be sure of the accuracy of our sources and the truth of our data, it is unsafe to draw generalization and conclusions. Skepticism arises in the mind of the reader, and he is inclined to doubt the value of any and all such researches.

As I said before, such a general criticism is entirely unfounded. ${ }^{2}$ It is perfectly possible to proceed as if the sources were all verified and the original data correctly drawn, as if the errors were negligible. When the results are all in, and lic before the eye, it may turn out that the errors of the

1 Reprinted in the Appendix of the present book.

${ }^{2}$ I have already tested the accuracy of some of the methods already employed, and published the general justification for these methods in Science, April 14, 1911, under the title "Historiometry as an Exact Science." This paper is reprinted in the Appendix of this volume. 
original data are not negligible, or that nothing but confusion can be made of the original data; in other words, that the research is a failure; but, on the other hand, it may turn out that the results contain within themselves something which proves that the original data must have been of sufficient worth. In other words, the amount of approximate error which the original data contained may be grasped as the research proceeds, and its measurement made a part of the problem itself.

This concept which it is so necessary for the reader to get at the start, and which I have said is fundamental in the development of historiometry, is perhaps most easily attained by recourse to concrete examples.

In "Heredity in Royalty" I came to the conclusion that heredity is a very strong force, and that enviromment is not. Can this conclusion have been wrongly arrived at because of the errors which history and biography necessarily contain? What I did in this research was first to bring together, as one collection, all the easily available statements concerning the mental and moral characteristics of royalty; second, to arrange the individuals in the order of their reputed merit (two kinds, mental and moral); third, to rearrange the individuals according to reputed ancestry (genealogical arrangement); fourth, to measure mathematically the correlations between individuals, close of kin, or more strictly, close of reputed kin. ${ }^{1}$ I showed that, when this was done, it was found that correlations existed agreeing substantially with those already obtained in the anthropometric laboratory.

${ }^{1}$ On page 16 of "Heredity in Royalty," I discussed the bearing of the error introduced, arising from the possibility that sometimes the aseribed father is not the real father. My view as there expressed is merely a statement of my own judgment in the matter, which was, that any error arising from this source would be slight. I have no reason to alter that opinion, but whit I ought to have done would have been to have swept away the whole ohjection by simply saying: these errors tend to lower the correlation ratios. Therefore, the true results are (as far as this question is coneerned) certainly as high as $I$ have found them, and probably a little bigher. 
As I wrote in Science, April 14, 1911: "Such would not be the case if historians perverted the truth greatly, or if for any other reason the truth were largely unattainable. To make this clear it is only necessary to think what the result would be if history were merely' 'a pack of lies agreed upon' as the extreme vicw puts it. We should then fail to properly pick out our true intellectual giants and runts. The result would be nothing but confusion. A whole series of errors would be distributed at random. This would aet like rain on waves and flatten down to a common level the real differenees between the individuals. The correlation measurements would fall, and we should get no results comparable to those obtained from the delicate and accurate measurements of the anthropometric laboratory.

"Furthermore, any weakness in the method of grading, any failure to properly classify the great men in the high grades and the degenerates in their proper grades, would work in preeisely the same direction, - to lower the correlation coefficients. The supposed errors of history and the difficulties of grading act as two united strains of tension to pull the coeffieients down towards zero, which would be the coefficient for random distribution. If the coefficients can stand the strain without declining, then, roughly speaking, we may conclude both that the historical foundation is just and that the method of procedure is sound.'

Once this simple mathematical principle is comprehended, it becomes evident that several speeific criticisms that were directed against "Heredity in Royalty" were entirely beside the mark, and were due to the inability of the reviewer to understand the significance of the very objections which he raised. These pretended scientific eriticisms appeared exclusively in literary or historical reviews, or in the daily press, not in journals devoted to seience. Although the reviewers in scientifie journals did not fall into such errors as the following, they did not call the attention of their readers to the point that the random errors of history, in this particular 
series, had hereby been shown to be trivial and immeasurable.

False criticisms like the following were fairly common. Some complained that the authorities (works consulted) were out of date or meagre in material. My reply is that while it is perfectly true that I took authorities uncritically, I had at the same time proved that such a method apparently introduces no error commensurate with the truth which it somehow does attain, truth evidently sufficiently accurate for the needs of this particular study. The point is that the "out-of-date authorities" would not, in their separate descriptions of different individuals, have any conscious or unconscious bias towards a theory of heredity. On the contrary, there is reason to suppose that they would be especially free from such a bias, beeause they wrote long ago, before there was any general belief in the force of heredity. Yet even with such material, blurred and incomplete as it was, the heredity factor was unmistakable; the strongly contrasted traits of character could still be seen in the hazy and ill-defined ensemble of only partially authenticated history. How strong then heredity must be! That should be the nature of the mental reaction growing out of the observation that poor authorities had been used. The same kind of reply is to be made to those who criticise the use made of encyclopædias and the arbitrary use of Lippincott's Biographical Dictionary as one of the criteria of admission into the grade called "genius."

Some few critics (newspaper critics only) wished to throw overboard all the results because of the great differences of opinion in regard to some historical characters. One cited Loyola and Luther, and asked what the result would be if in their cases one tried to balanee opinions and strike an average out of such notorious discord. My reply is that I was not concerned, for the time being, with Loyola and Luther. I was concerned with showing, among other things, that any presupposed conflict of opinions which some persons might 
have supposed to permeate history cannot be great, in at least one department of history, because if it were, the sequences which I have uncovered could not possibly be found.

Another type of criticism was made (chiefly in historical journals) which had no bearing on the main conclusions of the work. A historian would here and there sce a character described, or graded not in accordance with his personal judgment. He would point out and name those kings, queens, or other personages whose characterizations he believed unjust, and would then argue that because a portion of the work contained crror the rest might not be above suspicion; whereas he should have tried to show that the particular specific errors which he had noticed were of such a nature as to learl me falsely to magnify heredity. That is, he should have done so had he wished to prove the errors vitiated my conclusions. It was perfectly proper for him as historian to suggest a different opinion regarding the classifying and grading. I should be glad to readjust and improve these assignments of grades; but the general effect of such improvement would be to strengthen the conclusions already obtained. At least, that is what the probabilitios indicate. These conclusions I had been able to demonstrate, as clear and certain enough for ordinary purposes, even though I used rough data. If the data had been absolutely fallacious, my correlation ratios for offspring and fathers would have been approximately $r=0$. As a matter of fact this correlation was found for intellectual qualities to be $r=.30 .^{1}$

The only way justly to attack the conchusion from "Heredity in Royalty," that the judgments of historians are now proved and known to be a fair approximation to the truth, would be to show a bias in the material constantly working towards raising the correlation ratios, or clse to attack the work at its only subjective point, namely the arrangement into grades.

" "Heredity in Royalty." pp. 2\$1-283. If I had used more extensive and more authoritative biographies, instead of to a considerable extent relying on the encyclopæedias and on Lippincott's Biographical Dietionary, I should have perhaps obtained a correlation ratio somewhat higher than $r=.30$. 
Here my own personal judgment to some extent entered. If it can be shown that I have on the average unjustly overrated the kinsmen of the individuals in the highest grades, (9) and (10), I should then spuriously have raised the correlation ratios. A critic should take a few sections of the book at random and see if this tendency ean be detected.

To summarize the situation: If one wishes to discover a correlation between two historical variables (deviations from random distribution, or from the average type), one should start with materials supposed to be good; beeause only with true statements as clata, can one detect the full force of the correlation; but having found some correlation it is not necessary to go back and justify the materials used. Except there be a bias of the whole material towards the conclusion, the correlation found (if it sufficiently exceeds the probable error) is guarantee that some correlation exists which is, in all probability, cren greater in reality than the measurement indicates.

Another example of a research based upon data known to carry some seattering errors, yet yielding a conclusion all the more certain on this account, is the following: In the year 1909 I happened to wish to know whether more leading Americans of the present generation had been born in the cities than in the rural communities. In other words, had more leading Americans come from the eities than their population would learl one to expect, or have the eities failed to produce their proper quota? As a convenient way of answering this question I turned to the latest number of "Who's Who in America." Arithmetical computation showed at once the cities leading, and only a little further investigation was needed to prove that according to this book the eities had done more than their share, and with a wide margin for aecidental crror. Whereas about 16 per cent was all that (in proportion to the population) could be expected from the cities, they had actually furnished about 32 per cent. 
There are then but two conclusions; either that the editors have been unjustly partial, indeed doubly biassed towards men of eity birth, or that there is really something in city birth (either inheritance or cnvironment) that farours the achievement of notalility. It would be a valid criticism to suggest any was in which the list might supposedly be biassed towards those of city birth; but mless such specific criticism be made, any general criticism that the list contains seattering errors, contains names of doubtful merit, omits other names that ought to be included, is a eritieism that works in precisely the opposite direction from detracting from the belief that the eities have been the chicf birthplaces of notable Anericans.

To make this clear. lot us think of it in the following way : Unless the list hat heen made up of persons possessing some peculiarity, there would be no more and no less born in the eities than the population demanded. Some peculiarity in the list, some predilection on the part of the editors towards men not random samples of the citire population of the United States, is absolutely proved. Therefore, if the editors have not been biassed, the only other inference is that this olserved deriation in the birth ratios is associated with that quality which the book claims to select; namely, notability.

A list made up at random would show no greater number born in the cities than the total urban population demands. Next consicler what the result would be if a very bad list were used, one made up of only a fow of the real leaders, and almost entirely composed of mediocre or worthless names. Such a list could of course only give a very slight, perhaps doubtful, correlation between notability and eity birth.

Next consider what the result would be if a somewhat better list of names wore used. The truth of the matter would then begin to show itself more clearly. The better the list, the more the truth would stand out. In other words, if the list were worse (more full of error) than the one that 
I have used, it would bring out the fact less strongly; therefore, if the list of names were better (more ideally chosen) than the one that I have used, it would bring out the truth even more strongly than I have found it.

Two conclusions, then, are warranted: first, that a list which in any and every portion of its entirety shows twice the number born in the cities that random expectation calls for, must be worthy of being called a very good working list; and second, that the cities have produced probably more than twice their share of notables.

All this is said under the supposition that the list does not carry any prejudice in favour of the conclusion to which the investigator has come. This is a very important question, for if there be any special reasons why a constant, on the average unjust, bias enters, then the conclusion is in part artificially induced. It must be remembered that I have only said that if a general criticism is brought against the list of names (from random errors), this acts to strengthen the conclusion already obtained. If, on the other hand, a bias in favour of the conclusion is present in the original list, then it is a very different matter.

In this particular instance we start with the common-sense belief that the editors of this reference work have not compiled their list with the objeet of proving that eity-born boys reach a higher degree of leadership than non-urban. There may, however, be ways in which the list unconsciously and unjustly favours the eity born.

Criticisms of this sort are entirely proper, for it is part of the work of historiometry not only to avoid bias but to be able to detect it and measure it. Let it be suspected that part or the whole of the increase of eity-birth leadership is due to an excessive partiality towards professional men, and that the same result would not be found if business and practical types were considered. This is a fair criticism. The answer is, reinvestigate. Split the whole material into two parts, the practical business types and the learned, professional, then compare the two results. 
It is not to the point to discuss the possible special criticisms that might be raised à propos of this particular research. It is enough to say that any just criticism, raising the point of bias, should be answered. Any defect in the method which would in any way falsely magnify the conclusion ought to be asosly serutinized, but the general criticism that any and all sueh researches are rendered less solid and reliable on account of the ereneral errors of judgment which permeated the original material on which they rest, is an utterly false objection. The tendency of the random errors of history is to mask the true but hidden eauses, correlations, and other generalizations, which laws, though actually existing, are more or less buried or overlooked in the mass of historical detail. Any levice that can work out a general or contimous prineiple from the historieal elements floes so in spite of these rantom errors. This boing the ease, the random errors of history may be ignored (when generalized (atuses are sought), and the results camnot he wrong simply because the original material is known or supposed to carry some amount of random error.

The concrete example I have just given illustrates what may be aalled the paradox of historical generalization. The worse the material, the more certain is the generalized eonclusion, provided there be no bias in the selection of material towarels the conclusion reathed.

This statement does not apply to the usual types of historical investigation, and this, I take it, is the roasen why so many historians are unwilling, at first sight, to accept the truth of such a paradox. A typical problem for the historian is the measuring or juelging of some historieal detail. Take, for instance, the dispute concerning the real characteristics of Richard III of England. Surely it camot be that the worse our sourees the more certain we ean be of our eonclusions. The elifference is this: here there is no third point against which a triangulation is made and an overplus found which must be accepted as significant and taken as a lower 
limit of proof. In the case of city birth and leadership we measure these two elements over against a third element, namely, normal distribution of the population, and measure its deviation from this normal or random distribution.? In historiometric work there is this third element which is the novel and peculiar feature.

The case is quite different when we are dealing with details and not with generalizations and correlations. In dealing with the question of the real characteristics of Richard III of England an examination of the worth of each separate statement becomes necessary. The reason for this difference needs careful consideration. There is some assurance that the mere balancing or averaging of the opinions pro and con gives a good and true picture of any one king or prince specifically selected out of all royalty. This conclusion is drawn from the generalized conclusion that usually such a method must give fair approximation of the truth. But any one specific individual selected out of a group may be the very one to whom such a method of balancing opinions applies the least. What is true in the general is likely to be true in any special instance, provided we know nothing further about the particular instance. But as soon as we do know something about the particular instance the case may be altered. The same sort of reasoning applies in our ordinary human social relations and in our everyday knowledge of mankind. For some purposes we may wish to know as much as possible about some individual person. In default of special knowledge of the individual, any general knowledge as to his age, race, class, profession, or education, would help us to form an opinion about him, but a particular and intimate knowledge of the individual would be more to be desired, as long as our interest centres on the individual. On the other hand, for some purposes of generalization, as in anthropology, sociology, life insurance, etc., our interest may be general, not special. So our interest in history may be special and detailed, or it may be directed to discovering general principles, correlations, and causes. 
In studying the life of Richard III a few original documents may be worth a great deal more than the multitudinous statements of later historians, emanating as far as one can see from the writers under the patronage of Henry VII, Richard's rival and enemy. If an historian disbelieves the older and unfavourable verdict of history, he makes use of the reliance on probabilities, but his reliance is essentially subjective and personal, and a part of his general judgment and common-sense, as a result of his contact with men and with books. He knows, or thinks he knows, the probability of human ranity, the probability that certain documents found in certain places are likely to be genuine. He thinks that certain contemporary writers are more likely to be trustworthy than others, which ideas are based on other probabilities; he puts the whole together and gives what to his mind is the most probable view of the whole situation. The reader accepts, in so far as it fits in with his own judgment, but he never is obliged to do so in the way one is obliged to accept a mathematical demonstration.

It does not seem possible in the present state of knowledge to devise a method which shall give objective proof in problems of isolated periods or in questions of historical detail. Nor does it seem desirable to do so. We do not wish to eliminate the personal equation from the specialist of historical details. The personal equation is the best thing about him; or at least should be. It ought to represent advanced knowledge from advanced experience. But the historian who goes in for explaining general causes or even the special causes of limited periods is in a very different position. No excuse can be offered for the self-satisfied historian who plumes himself for the gratuitous task of confidently supplying the reader with the reasons why this or that has taken place. The difference is this. Many a man has been able to handle the purely descriptive side of history in a way to give fair satisfaction to the great majority of his intelligent critics. The world of scholarship as a whole is satisfied 
with most if not all of his statements; therefore something definite has been accomplished, something permanently worth while has been done when a specialist publishes a book or memoir of descriptive history and confines himself to facts and judgments.

But no one has ever gone high enough in subjective judgment to settle questions of historical causation. This is evidenced by the great diversity of interpretations, both major and minor, and the dissatisfaction, on every hand, which such attempts have always met. And even if there should arise a superhuman being whose subjective judgments were so perfect that he allotted all causes correctly, ordinary mortals would still need the proofs; otherwise, how should we know that he was right? The orthodox methods may suffice for those who seek to weigh documentary evidence and reconstruct the past. In so far as historians are unearthing Mss. and comparing sources and deciding in their own minds what evidence is genuine and what is false, no slurs can be cast at the modern school; their methods are scientific and their aims are in the majority of cases sincerely directed to the discovery of the truth. Nor are such specialists merely worthy of being called into court as witnesses of facts. They are also entitled to qualify as experts on questions involving opinions.

History as we commonly find it in the printed accounts must approximate sufficiently to what actually happened, to meet the need of ordinary purposes, both of scientific analysis and superstructure. Historians must have already sifted facts and reported judgments with a high degree of sanity and completeness (at least for some departments of history), otherwise the interlocking results of historiometry which I have found could most emphatically not be found. The phrase "report of judgments" I use to cover all expressions of evaluation of the traits of historical characters, good or bad, the general use of adjectives of praise and dispraise, and also the giving of opinions concerning the condition of a 
nation's army, navy, treasury, trade, and commerce, or other direct statements which historians make involving the use of judgment, but stopping short of questions of cause. It is very easy to say that George IV of England was immoral. It is not only easy to say, but it is easy to find agreement in the sources and to get agreement among the readers; to bring everything together and to arrive at this one conclusion and no other. It may be (judging from the naïve way in which some historians write) very easy for them to say why George IV was immoral, but it is not so easy for them to make other people believe it. ${ }^{1}$

An author who says "commeree declined" assumes a very different kind of responsibility from one who says "commerce declined because," etc. It is the unfounded, I might say confounded, introduction of the word because against which I protest. There may be a few obvious causes of broad historic movements for which general agreement can be reached without any specially arranged eontrivance for compelling the proof, but I do not happen to think of any for the moment. Even the classical assumptions that Rome declined beeause of its luxury, and Greece was injured through the rivalries of petty states, are open to serious objections, and to many counter-arguments; and even if it be agreed that these factors enter somewhat into the problem, unless we have some kind of a notion of how deeply they enter in, unless through some scientific scheme we have arranged the many contributing eauses somewhat in the order of their importance, what is the use?

Dogmatic statements do not and will not satisfy, so complicated are the problems of historical causation. The historian who glibly says, because of, and then trips lightly on

${ }_{1}$ My own belief that George IV was immoral primarily on account of his heredity is derived from scientific induetion. All the faets concerning the moral deviation of royalty can be explained only on the theory of gametic heredity. They can, on the whole, best be explained by leaving the influence of environment out. Therefore, what is true of the general is most probably true of any particular instance taken at random. 
his way to deal with some other political cataclysm or human enigma, and satisfy a psychology or political philosophy as superficial in the reader as it is in him, should be ridiculed out of existence.

Although the methods of objectivity and induction seem slow at first, results will multiply as time goes on, and one well-grounded research makes another that much easier. The paradox of historiometry, which I have explained at such length, is a mathematical concept which gives great encouragement to ventures in the domain of historical interpretation, especially because it shows that it may not be necessary for the investigator to spend a great deal of time deciding upon the reliability of the sources he proposes to use. He should start with authorities supposed to be good, because good authorities contain fewer random errors than do poor ones, and, therefore, any previously hidden truth will be forced to show itself more distinctly. He should, on beginning the research, consider the question of constant errors (bias towards the hypothesis which he has in mind) and before closing the researeh he should consider this question again, either to prove its triviality or measure its importance; but he need not concern himself again with the seattering errors. The random or scattering errors become important only should he wish special refinement of measurement. For instance, in the present research my conclusion is that monarehs have influenced history; moreover, that monarchs have influenced European history from the eleventh to the nineteenth century very much, and that the characteristics of monarchs are correlated with the conditions of their countries to at least a probable $r=.60 .^{1}$ None of these conclusions could have been falsely induced by the random or seattering errors. Consideration of random errors is necessary only when measuring the full correlation.

In all attempts to unravel causation in history, the comparative method is needed, and reliable results ean only be

11.00 being perfect correlation, .0 being no correlation. 
obtained after a wide range of historical reading has been methodically systematized. We must discover correlations, and after finding that $\mathrm{A}$ is correlated with $\mathrm{B}$ we must then devise ways of determining how much $\mathrm{A}$ is the cause of $\mathrm{B}$, or how much $\mathrm{B}$ is the cause of $\mathrm{A}$, or: if both are caused by still another force. We can only have a science of history by comparing facts drawn from a great many countries. We must not ignore the evidence from the smaller nations. A knowledge of the history of Holland, Denmark, Spain, Portugal, or even Mecklenburg, and Reuss may be, for some purposes, just as valuable as a knowledge of the history of Rome, or Greece, or England. The fourteen countries here studied are widely representative of the various people of Europe. I should like to have included Hungary, Poland, Grecee, Saxony, and Bavaria and several other countries. Indeed, the Italian cities might very profitably be studied in relation to the Sforzas, the Viscontis, and the Medicis. As every reader must imagine, the labour is considerable in bringing together all the relevant materials covering several centuries for any one country. But it would not have done to have stopped without a sufficiently large collection of elementary data. The number of elementary parts (miniature histories) which I have constructed (368) being large enough to meet statistical demands and to answer nearly all the questions which I had in mind at the start, I have stopped with this number.

The following fourteen chapters give a summary, as briefly as possible, of the history of the fourteen countries studied. They discuss the more concentrated tabulations found in the Appendix. If a monotonous story is thus presented, the reader must remember that it is only the repetition of observations that compels the surety of science. Probably no other single factor will be found as important as the one here emphasized; and if this be true, then the key to this section of European history is to be found in the material which lies ahead, the disclosure of which certainly merits the most careful scrutiny. 


\section{CHAPTER III}

\section{FRANCE}

Wiтh Hugh Capet (987-996) commences the history of the real and lasting French nation, as distinct from the Germanic Empire of Charlemagne, and therefore there is here, in many ways, a point of departure, clear cut and convenient. Yet there are drawbacks to beginning at so early a date The small nucleus, then called France, continued to grow as such. The era is near the beginning of the eleventh century (the approximate date from which I would wish to trace the histories of the various countries of Europe), and we here begin a new dynasty; but records of some periods are still very meagre, and the pen-portraits of certain sovereigns far from satisfactory. However, concerning a number of reigns, even for this early period, interesting and well-known facts are sufficiently authenticated for the main purpose of this inquiry, though it may be best to treat some sovereigns with less assurance, such as Henry I, Louis VII, Louis VIII, Philip IV, Louis X, Philip V, Charles IV. Even for Hugh Capet, famous though his name certainly is, material is lacking for a proper estimate of his personality and influence.

Hugh Capet was probably not a very great man, though more than a mediocre one. He possessed the art of managing the turbulent men who surrounded him, and often by subtle or conciliatory means adapted himself to the needs of his times. One must remember that the claims of Hugh were recognized by only a fraction of the entire population, and his rival, Charles of Lorraine, needed to be vanquished. One must also consider how circumscribed in domain and power 
the country was over which he held the title of king, a title which had long since failed to carry any especial dignity or influence. The lawless barons were strong. To them Hugh was scarcely more than an equal, and thus to gain his ends the new king felt himself obliged to make many handsome grants of territory, so that at the elose of his reign he had less land than when he began. Yet against all the warring interests of this troubled time, Hugh Capet held his own. He beat in battle the Carlovingian elaimant, maintained his dignity in the face of the Papacy and the Empire, gave a certain meaning to the sovereign power, and had his son and successor erowned during his own lifetime. In fact, the grand France of Richelieu and Louis XIV made its modest start.

Unfortunately for this embryonic nation the next king, Robert, was not cast in the ancestral mould. For three generations the vigour of Robert the Strong had been bequeathed to the male deseendants of that redoubtable warrior. Now a mentally weak, though kindly and pious, prince came upon the throne. The reign of Robert (996-1031) was long and inglorious. "A ceaseless struggle against the barons... The rising of the servile population ended in a sad slaughter of the peasants." A weak king in those days had always his own houschold to fear. Robert's latter years were beset with civil wars forced upon him by his own queen, and only son Henry, and Robert of Burgundy. "Burgundy and the duchy of Franee suffered under the ills which formed the sum of war in those days."

The conditions were not improved under Henry I, who ruled during the twenty-nine years following 1031. With petty wars, eivil wars, frontier wars, devastating invasion by the Normans, who eame within twenty miles of Paris, France stood for nothing and the kingly power was the same. Unfortunately our perception of the personal character of Henry I is extremely vague. Contemporary chronicles have left nothing of value, and later historians have de- 
scribed his traits in conflicting terms. It will be best to pass over this era entirely, for it cannot enlighten the present problem.

When Henry I died, his son Philip was then a child of seven years of age. The crown was of so little importance by this time that no one wanted it. Perhaps this is why no usurper seized the reins, and until Philip came of age, his brother-in-law, Count Baldwin of Flanders, was willingly given the regency, which he so ably maintained. Baldwin is credited with wisdom, energy, and prudence, and he soon brought about a decided ehange in the affairs of France. He curbed the nobles and suppressed sedition. The country enjoyed a seven years' breathing spell, and his untimely death was regretted by all. It is true that Baldwin's regency was luckily favoured by the Norman conquest of England, which diverted the foes of France towards other plunder. Baldwin's title of "Count" was virtually as good as that of king. He had, moreover, married a daughter of the late king. Therefore, Baldwin is entitled to rank among "royalty," and this period must be taken as the second example in favour of our thesis. Robert, the son of Hugh Capet, furnished the first, though in quite the opposite way.

The good influence of Baldwin lasted only during his lifetime, for his royal pupil Philip did not follow the excellent example set by his kinsman. Philip had a good education and was not deficient in natural aptitude, yet this promising young prince developed into one of the very worst of all the early kings, and the unhappy country had soon to know the terrors of misrule. Philip was not only weak and self-indulgent, but also devoid of any virtues. He was false, honourless, and grasping, lacking in judgment and courage, a dissolute libertine of the most extreme type. Under him France again became the scene of interminable petty warfare, dreariness, and desolation. The Normans again invaded the territory of the French. Mantes-sur-Seine was taken and burned, and the victors were pressing on, even to the gates of Paris, 
when, fortunately for France, the Norman leader, William the Conqueror, died.

When Philip was forty-seven years of age he retired into obscurity, - the most praiseworthy act of his life. His son Louis VI, then but a mere lad of nineteen, was called upon to assume the uneasy, and likewise unmeaning, sovereignty. Here was a man of different mettle. With him came a sudden and momentous change when viewed in the light of the entire history of the French nation, for only now did France as a true power begin.

When Louis VI took upon himself the burdens of government, the limits of the royal domain were very narrow. The pretended extent did not amount to one tenth of the present territory of France. In reality there was little more than the cities of Paris, Orleans, Étampes, Melun, and Compiegne; for the land between was held by the robber barons at war with each other or with the king. Almost within sight of Paris itself, the enemies of France could be seen. Five miles to the north stood the lord of Montmorency with his army. Fifteen miles to the south Montlhéry cut the royal domain in two by blocking the way to Orleans. There were many other rebellious chiefs on all sides. The valiant lad mustered what forces he could, and by dint of real genius for war, and ability to bring the forces of the clergy and the populace over to his side, subdued and humbled the rebels one by one. The frontiers were rendered secure, the poor found a protector, and one even sees the faint beginnings of independent commune life. All authorities agree that Louis VI was a man of very superior ability, and they likewise never fail to praise his many virtues and noble qualities. The change which came about was sudden, and a great contrast to the reigns of his predecessors. It is true that the Crusades lent their aid by diverting the attention of some of his enemies away to other lands, but aside from this, everything was against him. Louis VI had at the beginning the same feeble resources and the same lawless barons; yet he 
overcame all obstacles, and died one of the great men of his time.

Another notable figure of the period was the Abbé Suger, whom Louis VI prudently chose as his counsellor, and to whom much of the great work accomplished during his reign is said to be due. Fortunately for France the influence of this shrewd and politic churchman was equally great in the reign of Louis VII, at least during its early years, while this king was away on chimerical crusades. Under Suger the country enjoyed the blessings of peace and security. The foreign policy was strong. The finances were well administered. The royal power expanded and its revenues increased. Churches sprang up, cities renewed their franchises, and moreover something of liberty and justice was accorded to common men who glorified the name of the great prelate, and called him "Pater Patriæ."

Here was a country prospering without a great king, for Louis VII was at most mediocre. He was weak and pious, easily under the domination of the church, which fortunately had so good a leader. Louis was gentle, well-meaning, and virtuous, and indeed rather learned for the times. He may be placed in the doubtful or inferior grade intellectually, while the material conditions must be classified under the general term "progress." Louis VII might be placed in the middle grade, but to be on the safe side I grant this reign to count against my thesis, - the importance of royalty. I do not, however, grant it against the broad theory of the preponderant influence of a certain few individual personalities, for in Suger we find our notable man.

We now come to the second of the great French kings, Philip Augustus (1180-1223). When he began to reign alone he was but a lad of fifteen. The vassals and barons, on account of the youth of the king, thought that now was the time to make merry with the crown. They were considerably disappointed. What certain boy-kings have done in the way of dignified and successful leadership, immediately 
after coming into their own, is extraordinary. In the maturity of after life, these royal prodigies have always, as far as I recall, developed into superior or indeed extremely illustrious rulers.' They have, during their lives, time and time again been called upon personally to lead and direct their armies against the best generals of foreign realms, or to meet some rising tide of plotting factions within their own domestic circles. Judging by the record of their latter years, it would seem that these precocious princes must truly have been geniuses in embryo, and that their early triumphs could not have been the outcome of mere fortunate circumstances.

Philip Augustus at once began to show the mettle he was made of and the characteristic policy of his reign. $\mathrm{He}$ demanded subjection from all and took orders from no man. His untiring ambition was to get for himself and the monarchy which he represented, as much as he possibly could of that power and dominion which the great feudatory chiefs had so insolently and lawlessly administered. Being but a lad, his mother and uncles expected to keep him still in leading strings, but with the help of Henry of England and a following of young men of the realm, free lances, and paid men (Brabaçons) he showed his would-be repressors that he was indeed already a king. "Within five years and before he was twenty-one years old, this proud stripling grandson of the able Louis VI had won sixty-five chateaux in Vermandois, also the important city of Amiens, had vanquished Flanders and seized parts of it and had reduced to docile. servitude the prince of Champagne." 2

It is said that he had dreams of restoring the Empire of Charlemagne, and the story goes that about this time he was seen one day by his courtiers gnawing a green bough, and glaring about him wildly. One of them asked him boldly what he was thinking of, and he replied, "I am wondering

1 Richard II of England is an exception.

2 Lavisse, "Histoire de France," vol. iii, pt. i, p. 89. 
whether God will grant me or my heirs grace to raise France once more to the heights she reached in the days of Charlemagne."1 A few years later he had conquered Maine and Touraine, but much of this was restored.

The chief work of Philip Augustus was the conquest of Normandy. This he easily brought about because its ruler, John of England (of Magna Charta notoriety), was both weak in nature and resources, and had no proper following. John's subjects having turned against him, outraged at the murder of the little Prince Arthur, Philip found an open road in taking upon himself the burden of vengeance for the lad's death. Chateau Gaillard held out for a time against the French, but John himself did nothing save fly to England. When this famous castle fell and Rouen had been taken, all Normandy readily accepted the mastery of the French king, - feeling no doubt that Philip could not be worse than John. Thus a large and important territory was permanently added to the French monarchy. It was a question of kings; but it was brought about more through the weakness of one king than through the strength of another.

With Normandy came also those other possessions of the English crown, - Touraine, Anjou, Maine, and Poitou. France was opened to the sea from the Seine to the north, and its territory was more than doubled in extent. The other great event of Philip Augustus' life was his signal defeat of the triple alliance formed against the French by the English, Flemings, and Germans. At the battle of Bouvines in 1214 he worsted the Emperor Otto IV and won the first great French victory. After this, Philip lived in comparative tranquillity and devoted himself to the consolidation and improvement of his country. He encouraged the growth of cities, paved Paris, increased the efficiency of the army, and managed the finances well. Industry and commerce took new life and France was again on the upward road. Thus a period of marked national progress is synchronous with the 
presence of a remarkable personality. Philip Augustus was certainly a great king. As a conqueror and administrator he stands forth one of the most striking figures in early French history. His intellect was of the clear, cold, and crafty type. Ambition and force formed the most conspicuous traits of his character. Further analysis of his virtues and vices must be rather uncertain owing to the dearth of contemporary records. Some say he was hard on the lower classes, some say not. It can scarcely be supposed that he was a man of tender heart or super-refined scruples. "He loved wine and women," and "was sometimes given to angry fits of passion, but soon recovered himself." I Whether Philip Augustus was, strictly speaking, popular or not, we cannot say, but certainly his subjects believed in him and unquestionably followed him in the great work which he laid down for himself in early life, the realization of which he in such a great measure achieved.

After the reign of Philip Augustus there follows the brief period of three years, when Louis VIII sat upon the throne. The chief events of this reign were the submission of Lower Poitou, Limousin, and Perigord, a successful but costly crusade against the Albigenses, and the granting of freedom to the serfs in the fife of Etampes. All together it seems to have been a rather prosperous period. However, we know too little of the personal traits of Louis VIII to estimate his own position in the events of the time. Authorities differ as to his ability, some crediting him with vigour and understanding, others calling him weak, and attributing his activity to the promptings of his queen (the famous Blanche of Castile), about whom none differ, all praising her superior qualities. He appears to have been at least pious and chaste.

Louis VIII died in his fortieth year and was succeeded by his son Louis IX, then a boy eleven years old. Again the barons thought their time had come, but again, as in the early

${ }^{1}$ Lavisse, vol. iii, pt. i, p. 284. 
days of Philip Augustus, they were doomed to bitter disappointment. This time it was a woman who came to the fore, Blanche of Castile, daughter of Alfonso the Noble, and maternal granddaughter of one of England's greatest kings, Henry II.

Blanche, by her powers of fascination, won over the leader of the barons, Theobald of Champagne, and then by dint of rapid action and by securing the burghers of Paris for the royal side brought victory out of languid wars, until at last she found the country pacified and had even in the meanwhile actually extended the royal domains. The long quarrel with the Count of Toulouse came to an end with marked advantage to France, and thus the way was paved for the gradual absorption of the South. Beaucaire, Carcassonne, Béziers, Narbonne, Nîmes, Velay, and Albigeois were added to the territory of the crown; most worth while was the condition of tranquillity which Queen Blanche established as a foundation for the great work of her son Louis IX.

There seems to be no question about the high ability of Blanche, and the son was worthy of the mother, as she in her turn had been an honour to her own illustrious forebears. Blanche came of remarkable stock, and her sister Berengaria was one of the greatest and best of Spanish queens. Thus Louis IX, being a grandson of Philip Augustus, had, considering both sides of the house, a pedigree such as is seldom met with. The expectations of heredity did not fail, for Louis IX became one of the greatest and best of French kings, and all in all, one of the best and noblest characters of his time.

After her son reached his majority, and even up to the time of her death, the queen-mother did not cease to lend her councils and take an important part in the affairs of state. The whole period of Louis IX is forty-four years of signal prosperity. The chivalrous and pious king must needs (following the craze of the times) make two unprofitable and futile crusades, yet even such mistakes wore not serious 
and he reaped a certain glory. During the first of these crusades, the queen-mother successfully managed affairs at home. The second was of brief duration. It lasted but a few months, when the king contracted the fever which cost him his life. On the side of progress there is a great deal to more than outweigh these two ill-timed expeditions. Most important of all, the country remained within its own borders in a state of quietude while justice was well administered. Population, commerce, and industry increased; and with it the total wealth of the land. This is especially shown by the great number of public buildings such as hospitals, asylums, churches, and abbeys which sprang up. In addition to his great work of quieting feudal hostility and of destroying the strongholds of feudal independence, he added largely to the actual domain of the crown. Louis IX, who in his day was "King of Kings," the idol of his people, has lost no lustre in the passing centuries. He was canonized shortly after his death. For long ages his anniversary was solemnly kept by the French people, and to this day the name of Saint Louis stands among the very foremost in French history. He was not a great general; he was perhaps too scrupulously conscientious for that; but as an example of what one man may accomplish when the highest moral purposes are united to a steadfast aim, the patron saint of the French illustrates in the strongest way the force which springs from personal character.

Philip III (1270-1285) was a weak, ignorant, though pious prince, guided entirely by his counsellors. These were mostly lawyers, and seem to have known how to maintain the royal authority now that it was so well established. Internal tranquillity remained, and this is the most that can be said to its advantage. The actual territory of the crown was increased, but this came through inheritance and not by conquest. Languedoc, Vivarais, and Rouergue fell to Philip through the extinction of the House of St. Gilles, with the deaths of his uncle and wife. France received, in her external 
relations, a distinct check in two serious disasters, the "Sicilian Vespers," and the victory of Roger de Laria, which deprived Charles of Anjou (uncle of Philip III) of the throne of Naples. Furthermore, an expedition led into Aragon by Philip III himself met with poor success and cost the king his life.

Philip III was followed by Philip IV, Louis X, Philip V, and Charles IV. We know too little about the personal traits of these kings to bring their history into this discussion. The whole generation (1285-1328) was one of confusion, and in general one of decline. It is natural to feel that if these kings had been distinctly able, the records concerning them would not be so meagre.

After the death of Charles IV we come upon firmer ground. The character of Philip VI is very clearly drawn. He was brave and headstrong and as ambitious for military fame as he was for the idle glory of pomp and tournament; but he was totally lacking in most of the qualities needful in a king. Moderation and ideas of justice were far removed from his mind. Though pious and possessed of some generous impulses, he was vain, false, heartless, and violent, and worst of all for France, no high ability compensated. "His reign must be marked as a great beginning of woes to his nation. Philip tampered with the coin of the realm, and by vexatious restrictions interfered with and in fact almost stopped the course of trade throughout France. Thus he alienated the merchants and burghers, and at the same time dried up the sources of revenue. . . Commerce ceased to pass through France. ... France was in a state of desolate barbarism, her people sunk in misery. In one respect alone did the kingdom seem to gain. Philip bought Vienne and the district and city of Montpellier, to pay for which he debased the coin. Thus ended a dark and melancholy reign. All things seemed to be evil in France, oppression, war, pestilence, faithlessness in king and people, days of shame and distress." 1 It was during the reign of Philip VI that

1 Kitchin, vol. i, pp. 394,422 . 
the overwhelming French defeat at Crécy occurred and the beginning of the hundred years which placed France in chaos.

Another king almost exactly like Philip VI follows, and also a similar reign. John II, the son, appears to have inherited his traits exclusively from his father, Philip VI. $\mathrm{He}$ is described as rash, ignorant, obstinate, incapable, passionate, cruel, self-indulgent, gay, and luxurious. He was called "le bon" because he loved tournaments and dances. Affairs of state were left to weak administrators. France suffered the great defeat at Poitiers (1356). Everything went wrong. Finances were wasted. Taxes were excessive. Bands of lawless soldiery ranged the land. Anarchy was alone supreme. John himself was taken captive into England (little of a prize that he was), and his son Charles, afterwards known as Charles the Wise, ruled as regent during the four years' absence of this monarch. Charles, at the beginning of his regency, was but nineteen years of age, and although in later life he well merited the epithet which history has bestowed on him, at that period of his career Charles was anything but "the Wise." He was only a foolish, extravagant youth, rather indifferent to the seriousness of the situation. During the absence of John, darkness and confusion continued throughout France. The Jacquerie, an organization of the peasantry, made an unsuccessful attempt to govern Paris and wreak revenge upon the nobles. There was a further financial decline; and at the end, France had to submit to the humiliating Peace of Brétigny (1360), by which she gave up to England a vast extent of territory and agreed to pay a ransom for their king of $3,000,000$ francs. France was now smaller than she had been under Philip Augustus.

No clearer picture of the miseries of the times, and the utter dejection into which the nation had fallen, can be drawn than in the words of the unfortunate and pernicious King John himself. This oft-quoted passage appeared in connection with a certain ordinance which he issued about this time, 
in which the king takes occasion to excuse the shame of the Peace of Brétigny. "By the space of four years and over have we and this our people ever sustained and suffered many ills, discomfitures and griefs; for as these grew daily worse and worse, tidings come to us how that the people of our realm were divided, and were slaying and destroying each other and giving themselves up to rebellion and disobedience, and were committing divers horrible and enormous crimes, such as made it plain that had such things gone on, our realm and people would have been utterly destroyed, with perdition of all they had. Wherefore, all things considered, we made the aforesaid peace; for we have found that in our own realm there have been divisions and rebellions, robbery, pillage, arson, larcenies, seizures, violence, oppressions, exactions, extortions, and many other cruel misdeeds and excesses, justice ill-administered, many new taxes levied, and much scizing, carrying off and putting to ransom of personages, stores, horses, beasts and other goods, whereby all industry is at an end." It would seem that the king imagined that this woful state of affairs was somehow associated with his own enforced absence. He had indeed little ground for such a vain belief.

King John returned to France for a brief space and then went back again into English captivity. During these years of John's return to France (1360-1364) Charles also acted as regent; but he had not yet begun to show the exceptional strength and practical wisdom for which he became famous after the death of his father, who, fortunately for France, was taken off in 1364. These four years were years of disorder and misery, without a soul to hold the anarehy in check. The "free companies" ranged the land, and want and pestilence added to the awful scene.

With the actual reign of Charles $\mathrm{V}$ occurred a remarkable change, both in the character of the king himself and in the visible conditions of the country. Charles was now twentyseven years of age. He had always been crafty in furthering 
his aims and not devoid of natural ability, but he had shown himself indifferent to affairs of state, - a spendthrift in his habits and a poor and cowardly soldier in the ficld. Now he took to work and directed everything. He worked hard in his own methodical, mysterious, and scheming way, shut up in his closet, a sinister figure not unlike Philip II of Spain, with all the strings of government leading from his own person. Charles $\mathrm{V}$ never himself took the field, but he knew how to choose the ablest commanders to do the fighting for him, and found in Du Guesclin and others, men to carry out his most pressing needs, - the abolition of the roving "free companies" and the expulsion of the English from French soil. The king shrewdly turned the one against the other, and sent the "free companies" to fight the English, who were then with the Black Prince in Spain.

It is not necessary to go into details regarding all the warfare of this reign. It is sufficient to say that Charles' policy was successful, that the tottering monarchy again became powerful, and that law and order were reëstablished. The English were gradually driven back to their island, until at the close of his reign scarcely anything of importance remained to them within the confines of present France.

In addition to accomplishing this weighty task, general peace and order led to an increase in the general prosperity of all classes. The internal administration was good and the financial condition improved. "The taxation was no doubt heavy and enforced on clergy and lay folk alike, but in return there was peace and security during which men could work."

Charles $V$ was unquestionably a very able sovereign, and the true fountain-head from which the various beneficial measures sprang. Thus the fourth important period of French growth, 1364-1380, was under the leadership of the fourth distinctly superior king; the other three being Louis VI, 1100-1137, Philip Augustus, 1180-1223, and Louis IX, 1263-1270. 
The brilliant reign of Charles $\mathrm{V}$ was followed by the minority of Charles VI, - some eight miserable years, until this half-witted youth came to his legal majority. Years of diseretion Charles VI never attained. The guidance of the government was intrusted to his three uncles, a worthless trio. Each worked for his selfish interests. The ruling power was so much divided that it is difficult to correlate the traits of any one, or all of them, with the condition of times. The period illustrates the rapid cessation of progress and order as soon as a rugged king was removed by death, and no other suitable person was on hand to take his place. The rule of the uncles was disastrous for France; "no good government seemed possible for that unhappy land."

Charles VI was feeble-minded even as a youth. Before he reached full manhood his mind gave way entirely, influenced partly by debauchery; and he was ever after, except for lucid periods of short duration, a mad king. The same dismal political and economic conditions returned to France as in the reign of the weak and useless John. Since the death of Edward III and the Black Prince, England had been falling back under her own weak king, Richard II, while France had been steadily rising under the leadership of Charles the Wise. Now, under Charles the Mad, the reverse was to take place, and there is no more gloomy period in French history than the coming fifty years.

France lost at Agincourt. Rouen was taken by the English. To add to this were burdens from excessive taxation, and riots and turbulence of civil wars, as the country was torn asunder under various factions. Moreover, Burgundy, under a line of able dukes, was gradually overshadowing the Freneh monarchy. This inglorious period lasted all through the reign of Charles VI and continued unabated for about seven years into the reign of his successor, Charles VII. The turn in the tide is again synchronous with the appearance of a remarkable personality, but this time it is no royal will that stems the onrushing current of disso- 
lution. It is a poor peasant girl of Domrémy whose inspired leadership is to rouse the French nation and turn defeat into victory and mark an epoch in the upbuilding of France.

With the siege of Orleans, in 1429, the fortunes of the French were at their lowest ebb. The city was about to surrender. Joan of Arc personally led and inspired the troops and raised the siege. Whatever may have been the secret of her mysterious power, the years which followed demonstrated that the relief of Orleans was indeed the end of the long period of decline which, broken only by the reign of Charles the Wise, had been dragging on in France for more than a hundred years. The Maid of Orleans was not permitted to serve long in the deliverance of her country, but before her death the English were already broken.

Charles VII did nothing to save the incomparable heroine, to whom he owed his throne, and in fact did little at any time that can evoke the historian's praise. He was a shallow, lazy, self-indulgent prince, temporarily rousing himself, but ever sinking back in debauchery. His end was wretched in the extreme, and he died beset by terrors and delusions, almost as insane as his father, Charles VI. Charles VII, however, was not without prudence, patience, and judgment, and in the choice of servants he was particularly fortunate. $\mathrm{He}$ was indeed the "well-served," sometimes also called Charles "the victorious," but his victories were the victories of others, to which Joan of Arc, the able Dunois, and the Dauphin (afterwards the crafty and celebrated Louis XI) contributed. During the reign of Charles VII the English were driven out of all France, save three seacoast towns. Taxation was regulated, a standing army was organized and well established, lawlessness was suppressed and finances were reformed; yet this reign cannot be taken as counting to the credit of royalty. Charles VII may belong in the doubtful class of "plus or minus," as far as mental qualities are concerned, or he may belong to the inferior group; it is diffi- 
cult to say. The general misery which accompanied the Hundred Years' War did not by any means disappear, yet all in all, the condition of France was clearly one of progress; and we shall take the king at "minus" to be on the safe side, and let this reign stand as an exception.

The son of Charles VII had rendered great assistance to his father, but he had also turned in rebellion against him. He had filled his father's mind with strange terrors until, his besotten intellect giving way, he died of starvation, fearful lest the son should poison him. This son became one of the best known kings in history, - the notorious old schemer, Louis XI. We think of him as a sly, suspicious, heartless creature, a rat-like contriver of mischief. It is hard to find his personal moral virtues; yet France grew notably stronger in many ways under this silent, sinister, despotic ruler. Perhaps Louis XI really had the good of his country at heart when on his death-bed he expressed his only wish that he might live to put the affairs of state in a little better order. As it was, a great work had been accomplished. In the first place, the actual territory of France was greatly enlarged. Furthermore, it was unified and strengthened, and rendered a compact and powerful entity. With security within its borders, trade and commerce (especially the cities, the corporations, and the silk and mining industries) made rapid advance. The country grew richer, and although the taxes were heavy, they could well be borne. There was an undoubted progress on the economic side during this reign. The only serious point against the administration of Louis XI was that the strongly centralized government seriously undermined the personal liberties of the people. It is said to have prepared the way for the France of Richelieu and Louis XIV. Be that as it may, the marks of territorial and economic growth are so noteworthy, and the ambition, industry, and ability of the king so well acknowledged that the reign affords a clear example of marked progress under an exceptionally able, though morally deformed, ruler. 
The next period, a regency during the minority of Charles VIII, was intrusted to his sister Anne, who proved exceptionally gifted. She was energetic and well-informed, firm, wise, and prudent. Like her father, her virtues were not her strong point. She was of an austere and haughty temperament, selfish, perhaps unscrupulous in her methods; but as far as the results of her rule of eight years were concerned they were all on the favourable side. Intrigues and revolts were suppressed. France triumphed over the rivalry of Austria. The allies were defeated. Brittany was forced to submission. There was even one important internal reform, - a new method of election of the States General.

Charles VIII unfortunately did not resemble his elder sister and inherit the superior ability of their father. No contrast could be greater than that between Louis XI and Charles VIII, called "the Affable," who in 1491 married and began to rule independent of the regent. He was then twenty-one years of age, a self-willed prince, deformed in body and weak in mind. He was indeed amiable and gracious, and filled with romantic ambition, but lacked judgment, and his education had been seriously neglected. To ignorance he added debauchery, so there is little to be said in his praise. Foolish and quixotic, the story of his reign reflects the character of the man. The chief event was the Italian campaign, part of that ill-advised and useless chain of events in which the princes of France laid claim to the throne of Naples and Sicily. What Charles VIII conquered he soon lost, and the wars only wasted the resources of France and brought no advantage. During the reign of Charles VIII, France also lost Cerdagne, Rousillon, Burgundy, and Artois. Trade and industry remained about the same, but the reign as a whole was certainly a weak one, and the king both mentally and morally a minus quantity.

During the reign of Louis XII (1498-1515) there are a number of points which definitely count on the side of progress. The finances were, brought into good order. There was an 
improvement in the army, as well as in the condition of agriculture, and in the administration of justice. The arts from Italy, especially architecture, made a notable advance. It does not appear that the king himself was strongly influential in this upward movement, except in so far as he relied on able ministers (chiefly d'Amboise), though perhaps he had the good of the people at heart. Louis XII is altogether a puzzling character to understand. Undoubtedly a bon enfant, a humane king, except in war, when he was correspondingly cruel, Louis XII was far too lazy and self-indulgent, and of too narrow a mind to bring about the marked improvements of his reign. A leading authority says that his intellect was superior to that of Charles VIII, but not above mediocrity. His lack of judgment allowed him to be drawn into Italian affairs, and this foreign policy was always weak. Yet on the whole this period must be considered one of progress; and although the ability of Louis XII may properly belong in the middle grade, for the sake of being in a secure position I will place him in the minus or inferior category. This is the third and last example in French history in which the intellectual rating of the king and the conditions of the country fall in diametrically conflicting grades.

Much may be said on both sides concerning the reign of Francis I, and also there is much to be said pro and con in regard to the mental endowments of the king himself. He was brilliant and accomplished, called "the king of culture," brave and ambitious, but his gifts were superficial and his chivalry a mockery. Though shallow in brain and heart, Francis was undoubtedly an exceptional man and played a great figure in his day. The marked advance in wealth, industries, agriculture, and internal trade, the increase in population (especially the new skilled artisans from Florence), and the judicial reforms may be taken as offsetting the high taxation, and the wasting of resources in foreign wars. These wars were, on the whole, neither successful nor unsuccessful. They brought no new territory, yet France, beset as she was 
by many powerful enemies, held her own, and in the end remained intact.

The wars eontinued through the reign of Henry II (15471559), ending in the Peace of Cateau-Cambrésis. The terms of this treaty showed the indecisive result of the long confliet waged chiefly against the House of Hapsburg. Financial resources suffered a further deeline, and likewise, as in the period of Francis I, industry continued to advance. The reign of Henry II falls in the doubtful grade. Henry himself had little influence on the affairs of his time. It was really the reign of the Constable Anne of Montmoreney, Diana of Poitiers, and the Duke of Guise. Henry was of medioere or inferior intelligenee, dull, gloomy, and obstinate. He was perhaps honest, and not evil in his intentions, but his character lacked strength and he was much under the influence of his aged mistress, Diana of Poitiers.

Francis II was sixteen years old at the time of his father's death. Being a feeble, siekly, backward youth, the government of the nation fell naturally into the hands of others. In a divided regency they intrigued for power, until the king died, a year and a half after his accession. The Dukes of Guise, Charles and Francis, had charge of the civil and military affairs, respectively, while Catherine de' Medici was regent in title but without influence. This divided state of the regency is reflected in the conditions of the times. Violence, party factions, civil and religious strife, make up the story of France during these sorry months. This condition eontinued during the minority of Charles IX, younger brother of the late king. The religious wars injured mereantile and industrial aetivity, but there are several points on the favourable side. Catherine de' Medici was now sole regent. This remarkable and gifted woman, so notorious for her unscrupulous eareer, had the good sense to appoint as prime minister Michel de L'Hôpital. To him are ascribed the measures taken to reduce the debt and to place the finanees in a better condition, and also the reforms in the administration of 
justice. To the credit of France we may add that Havre was retaken in 1563 . Thus the minority of Charles IX, so troubled by the religious wars, is not a period of frank decline. Whether these favourable aspects outweigh the unfavourable, it is impossible to say. I shall allow this regency to rest in the doubtful elass. At the head of affairs was a woman of indisputable ability, devoid of moral sense.

In 1571 Charles IX became twenty-one years old, therefore the next three years must be charged to him, although his personal influence was very slight. He was a poor, weak, vacillating creature, diseased in mind and body, immoral and dishonourable, completely under the control of Italian partisans. The religious wars and party struggles plunged France deeper still in ruin and destitution. Taxes became heavier, trade and industry made further decline. Nor did the debacle cease under Henry III, - idle, childish, and dissipated, one of the weakest of kings both mentally and morally. France reached her lowest point since the Hundred Years' War. National decadence can go no farther than the condition pictured in the single word "anarchy." Either a foreign power takes control or a great man arises in the realm. ${ }^{1}$

Now under the White Plume of Navarre came forward another Henry of the royal blood of France, who was destined to bring an end to all the civil wars. Henry of Navarre, afterwards Henry the Great, or Fourth, of France, found a way to solve the difficulties of his time. We need not enter into the question of the motives which led to abjuration of his religion for the sake of the crown, or into the details of the wars which ended in a triumph for reason and toleration. It is sufficient to recognize first that, whatever may have been the faults of Henry IV, he was a king of decidedly superior ability, and second that during his régime France prospered immensely. The founder of the Bourbon dynasty was not a man of good education or high moral character,

\footnotetext{
1 Franee never lacked great men; in faet, she has been, more than any other nation, fertile in most forms of genius; but her specialty has not been statesmen.
} 
but he possessed, nevertheless, in a conspicuous degree, certain qualities which enabled him to shine, first and always as a leader of men, and to live even to this day as the great hero of the French people, Henri Quatre, their beau-ideal of a warrior, a statesman, and a king. Gifted with tremendous energy, dauntless courage, and an intellectual fervour at once vigorous and sane, his example and eloquence inspired every one. France had long needed a master. The master had at last arrived. We see in his later life, selfishness, sensuality, light-hearted ingratitude, but all through his reign we cannot fail to admire the outward marks of his great achievements, and a glorious change in the condition of France.

First of all, peace and order were secured and maintained. Then in 1597 the king took the Lord of Rosny, afterwards famous as the Duke of Sully, as his right-hand man, and the Herculean reforms began. France advanced in practically every way that a country's material interests can advance. Financial reforms, improvement in the army, better roads, more bridges, the beginnings of canals, the remodelling of Paris, - advance in agriculture, increase in trade and industry, and the acquisition of new and important territory, are the marks of the reign of Henry IV. He was one of the four greatest kings of France, and it was in his reign that France experienced one of her four greatest periods of material progress.

An abrupt change took place in 1610, with the assassination of Henry IV. Now a "great man" had gone, and a scheming, capricious woman found her way to the helm of state. Marie de Medici (who acted as regent during the uninspiring years when Louis XIII was a youth) has little to recommend her in the eyes of the historian. Her methods were petty, her ideals low, and her capacity was of a narrow and inferior order. Her government being always in a state of indecision and feebleness, the foreign prestige of France was considerably weakened. Industry experienced a sudden 
check, and the burdens of taxation increased, while various grandees depleted the treasury. The royal power did not diminish, but it passed into acknowledgedly weak hands, and the regency of Marie de Medici became a period of frank decline.

In 1617 the influence of this woman came to an end, and her favourites, the Concini, were put to death. Louis XIII was then sixteen years of age. From this time until December, 1621, another incompetent and unscrupulous person, de Luynes, held the chief control. Conditions continued as before, with no glory to record for these four years of confusion and intrigue. The Huguenots took heart and organized themselves very strongly, threatening even complete political severance from France. The attack in Languedoc was unsuccessful and cost the lives of many French soldiers, among others de Luynes himself. He died of malignant fever December 21, 1621.

This seems a suitable date to consider as beginning the true reign of Louis XIII, although he had been declared officially of age in 1614, when only thirteen years old. He was now nearly twenty-one, and must be considered the sovereign ruler of France, just as if Richelieu (who from this time on did in fact control everything) had not at all existed. No example of a weak king made glorious by a great minister is better known or more quickly cited than that of Louis XIII, who was so completely overshadowed by the personality of Richelieu. But if the internal conditions of the country are examined in the light of modern opinions, it is questionable if, even here, France made genuine progress under non-royal leadership. There are excellent examples of incontestable growth under feeble kings, but this does not happen to be one of them. Of the outward splendour, there can be no doubt; nor will any one question the enhanced political prestige which made France the centre of the political stage and kept her in the lime-light during all the world movements of that century. 
The policy of Richelieu may be summarized under three heads, - humiliation of the house of Austria, centralization and aggrandizement of the monarchial power, and suppression of the Huguenots. In all this he was eminently successful. The armies of France were, in the end, everywhere victorious, and all parties and powers bowed to Richelieu's will. Even some new territories, like Sedan, Roussillon, and Catalonia, were added to the crown. Yet there are several serious charges brought against the administration of the great cardinal, a régime which, in point of time, coincides almost exactly with the reign of Louis XIII. The great wars could not be carried on except at an equal financial cost; and the absolute centralization could not be instituted save at the expense of personal liberty and civic independence. While the taxes increased, the lavishness of the government augmented beyond all bounds, and the deficit steadily grew. Internal discord and conspiracies were common. Although the manufacture of eertain luxuries, like silk and tapestries, increased (especially in Paris), trade and industry made on the whole but little advance. Commerce with the Levant and with the North American colonies declined; and furthermore, the common people as a whole were impoverished rather than enriched during this famous period of outward glory. The king himself was unquestionably a weak man. The period itself must be placed in the middle grade.

On the death of Louis XIII, Anne of Austria became regent. Her intellect was of the narrow, intriguing type, lacking in depth and political capacity. Neither in virtues nor in vices was she a striking figure. The eight years of her regency resemble very closely the reign of Louis XIII. France gained outwardly and politically. The treaty of Westphalia brought prestige and territory, but the strictly internal conditions continued on the downward road. Taxes became more burdensome, while public and private wealth declined, as did commerce and agriculture.

We now come to the famous reign of Louis XIV, which, 
long and complicated as it was, may be judged and described in a very few words. The first portion, up to 1683 , was a period of progress, the last portion was just as eertainly one of decline. This is so generally agreed upon, relates to and includes such a eomplete summary of all conditions of political and material affairs, that further detail is unnecessary. France first progressed, and then in turn degenerated. It does not seem possible to satisfy oneself whether at the end of the reign the nation was actually better off or worse off than it was at the start. The personal eharacteristics of the sovereign were well marked, and few monarchs have left a better defined or more generally remembered portrait of themselves in the pages of history than Louis XIV. The vain and egotistical figure, with the high heels, the great wig, and the walking-stick, the admired eentre of all things, goes strutting through the dazzling but artificial age. Yet the very fact that Louis XIV was able to keep so much power and command so mueh glory speaks something for the personality of the man. The "Sun King" was eertainly no ordinary mortal. He had a great eapacity for work, an unbounded ambition, a good knowledge of men and of methods to gain his ends, and had what was perhaps more essential in enabling him to play his part with such selfish sueeess, an unconquerable will which seldom bowed to another's wishes.

The long reign of Louis XIV was followed by the regency of the brilliant and dissolute Duke of Orleans, 1715-1723. The eonditions here belong also to the middle grade, - on the one hand weak diplomaey and finaneial disorder, on the other improvements in agriculture, road, canals, trade, and industry. ${ }^{1}$

The regeney of the Duke of Orleans was followed by that of the Duke of Bourbon, 1723-1726. This brief period

1 These last four periods are not particularly illuminating to the measurer of royal influences, because no one of them, as far as conditions of the country are concerned, belongs definitely on either side of the scale. Their effect is to slightly lower the final correlation figures. 
appears to have been weak, both from the financial and diplomatic standpoint. For Bourbon himself there is no good word. His mind was brutal, his character greedy and debauched. He was completely under the influence of his mistress, the Marquise de Prie.

Five years' ministry of the cardinal de Fleury brings us to 1731 , the time when Louis $\mathrm{XV}$ was twenty-one years of age. For the sake of being consistent, I will charge these five ycars to non-royal rule, and the years after to the king himself. Fleury's rule "was not strong for good or for evil; if no great reforms mark it, still it was free from exacting tyranny." 1 The picture on the whole, however, as gained from the consensus of opinion is rather favourable than otherwise. The government of Fleury extended twelve years further into the reign of Louis $\mathrm{XV}$, and its total value in the end may be somewhat problematical, but I shall take these first five years, which alone concern us here, as beneficial or "plus" in the rating.

Louis XV, who held the throne until 1774, proved himself, both as man and king, among the weakest and most despicable of all royalty. He had little capacity and is ouly famous as a libertine. Timid, indolent, and sensuous, he was at the same time cold-blooded and indifferent to the sufferings of others. One finds nothing good in his make-up. His long reign, covering the half of the eighteenth century, is one of the least glorious in the anmals of France. The Seven Years' War was a great disaster and Canala was lost. The political and military affairs of the country took on a most decadent aspect. Commerce and agriculture declined. The financial condition approached bankruptey, while taxes became more and more burdensome, until the peasantry were reduced to the most extreme misery. The wretched conditions multiplied until even the dull wit of the king saw ahead the deluge which was so soon to swcep away a rotten structure and bring an end to his ancient line.

${ }^{1}$ Kitchin, vol. iii, p. $393 . \quad$ Ed. 1894. 
Following the death of Louis $\mathrm{XV}$, the conditions improved for a time, in the reign of Louis XVI. Under Turgot, 17741776 , financial and agrieultural betterment is apparent, and during the American Revolution, France grew stronger through her vietories on land and sea, and through her diplomatic success. But the latter half of the reign of Louis XVI, presenting as it does one of the most frightful pictures in European history, must be held to more than outweigh the earlier years of moderate improvement. Whatever may be thought of the ultimate effects of the French Revolution on the progress of France, and on the world as a whole, the actual ten years preceding the execution of the king were years of marked decline. The national finances were so depleted that the country found itself again on the verge of bankruptcy. The army reached a stage of utter confusion. Famine and misery increased among the lower classes until the reign ended in the anarehy of the Revolution. The intellectual standing of Louis XVI himself is not particularly easy to fix, for he seems to belong somewhere between medioerity and marked defieiency. Probably he more justly belongs to the lower grade. He was undoubtedly weak and vacillating, and timid at times, although courageous enough at the last. All his acts appear to have been governed by ill-timed obstinaey and a general lack of judgment. He was truly well-meaning and had many private virtues, but as a king he was certainly a complete failure.

Looking backward over the entire range of French history from the time of Hugh Capet to the Revolution, the summaries in the Appendix show that the correlation is very high between rulers and political and economic changes. There are forty-five periods, twenty-seven of which give identical symbols (i.e., ruler + paralleled by + conditions, ete.). There are only three cases of conflict. The first of these exceptional instances is the progress under the weak Louis VII, which seems in part due to the leadership of Suger, and in part the expression of a social change which invigorated town growth during this era. Again during the fifteenth century, 
in the age of Joan of Arc, France progressed though under a weak king. This continued after the death of the maid, and does not seem ascribable to any one person. Various and general causes again seem contributory in the reign of Louis XII. On the whole it is somewhat surprising that only three cases of conflict can be found in the forty-five periods. France has had a large population for a very long time. For centuries prior to the Revolution the population of France was many times as great as that of Great Britain. In most forms of genius France has not been behind her ancient rival, but in the kind of genius which makes a statesman, all historiometric research shows France to be deficient. The French as a people have never shown any great ability in government; their history from the tenth to the nineteenth century proves that little material or political progress was made by the Latin race except under the guidance of a royal stock essentially Germanic-Scandinavian in its origin. 


\section{CHAPTER IV}

\section{CASTILE}

Modern Christian Spain, like France, took a modest beginning. In and about the northern mountains of the Peninsula, in rugged fastnesses, or inaccessible valleys, a few unconquered tribes lived on during the centuries of Moslem domination. From these narrow territories developed the independent kingdoms of Leon, Castile, Navarre, Aragon, and the province of Catalonia, which, sometimes in part uniting and often again separating, finally coalesced in the early part of the sixteenth century into the grand Spanish monarchy of world-wide influence. The early history of these separate kingdoms is very complicated. Genealogical accidents, or family feuds, often brought two or more regions under the rule of one king, only to be parcelled out again to his several heirs, as was the custom among Germanic peoples, and the royal families were Northerners in origin.

It is best for the purposes of the present analysis to confine ourselves to tracing first the growth of Castile and then of Aragon, for most of the remaining territory was soon united to one or other of these crowns. Navarre played a part of little importance, and was for a time under the administration of the kings of France.

It is difficult to know just where to begin an analysis of early Spanish history. Facts come but slowly out of the mists of obscurity and romance, and, moreover, there is said to have been a tendency on the part of the early chroniclers to distort the truth, to exaggerate the prowess and virtues of their greater rulers, and at the same time to indulge in 
unwarranted censure were the kings unsuccessful in their time. If such be the case, of course a spurious importance would be given the sceptre of royalty. I wish, however, to begin with as remote a period as possible because it is interesting to trace the development of the earliest germs of what was afterwards a great growth. Furthermore, an impartial survey of this very age throws some light on the question of the probable validity of the historical evidence itself. There are at least two points, which I shall discuss later on, which seem to make good reasons for thinking that the estimates concerning these early sovereigns, as we find them to-day in modern histories, are not so far out of the way after all.

Sancho el Mayor, a descendant of the counts and kings of Navarre, became also count or first king of Castile in right of his wife, Nuña Elvira. He consolidated his dominions and extended them by conquest and became in time virtual master of all Christian Spain with the exception of Catalonia. His appellation "el Mayor" or "the Great" may have referred to the greatness of his sway, or may have been given for personal qualities. Beyond this epithet we have no characterizations by which to estimate his ability. At his death in 1035 the kingdom was reclivided in accordance with earlier territorial limits. Aragon was left to his natural son Ramiro. Castile fell to Ferdinand, and the accession of this monarch is a good point at which to commence the discussion.

Ferdinand (1035-1065), the first of that name in Castile, stands out in the pages of history, in spite of the comparative darkness of the period, as a clear-cut and distinctive character, a great and on the whole a good king. The chief events of his reign were certainly all on the sicle of growth, consolidation, and progress. Important achievements were: the successful government of the kingdom of Leon, which came by marriage, granting of fueros to the people of the towns, frustration of the dastardly attempt against Navarre, the king- 
dom of his brother Garcia, and the wide conquests of cities and territories at the expense of Mohammedan power. Both Ferdinand and his father are blamed for lack of foresight in dividing their domains among their several sons, but there seems no point in blaming them; they were merely following a general custom.

At the death of Ferdinand, Castile passed to the elder son Sancho, while Leon went to Alfonso, who afterwards gained the greater country as well. The reign of Sancho II was brief and ignoble. It illustrates nothing save the unrewarded cupidity of a typically villainous king. The whole period is obscure, but it is stated that Sancho provoked an unwarranted war against his brother Alfonso, and was himself treacherously murdered outside the gate of Zamora, in 1072 .

The brother Alfonso then came into undisputed possession of both Leon and Castile. The reign of this monarch lasted thirty-seven years and is replete with heroic annals which picture "the dawn of Christian prosperity in Spain" with thirty-nine victories against the Mohammedans and only two defeats. The towns received further privileges, but the signal fact is the great extension of territory to the south, and the capture of the important city of Toledo to crown and set it off. Alfonso himself is described in terms of praise for his strength and wisdom, his activity and his heroism. Be that as it may, we at least have here an undoubted advance occurring during a long reign of a single king and during the period of a supposedly vigorous personality. Alfonso the Brave appears to have been a fierce, relentless master-spirit. He was much eulogized by the troubadours of the time, who doubtless idealized him as a hero and a knight; but it is interesting to note that even the Arabs admitted that Alfonso was true to his word.

Alfonso the Brave died in 1109, and Castile fell suddenly into a period of great confusion, civil wars, party strife, and general lawlessness. The Christians waged constant war against each other, but never once advanced the cross at the 
expense of the crescent. The seventeen years of this ignoble reign were under the notorious Urraca, one of the most severely condemned queens in European history. She was greedy, reckless, and supposedly incompetent, as well as vicious from every point of view.

At her death in 1126, her son Alfonso "the Emperor" came upon the throne. Events then took a different turn, and compared with the previous period Castile was fortunate. The turbulent nobles were silenced and the forces of the country unified. Much of this strength was uselessly expended in fighting Aragon and Portugal, but, on the contrary, successful wars which Alfonso carried on against the Mohammedans resulted in such important and extensive conquests that the reign must count for progress. One does not get a very clear idea of the personal qualities of this Alfonso, who so ostentatiously assumed that title of "Emperor," but from what records there are, he seems to have been an exceptionally brave and ambitious warrior and at least above mediocrity in intellectual vigour.

The reign of his son Sancho III (1157-1158) contains a successful war against Navarre and some further triumphs over the Moors; but since we know nothing of the character of this king, who died about a year after his accession, we may omit this brief period from cliscussion. It was followed by one of those unfortunate minorities which occurred so often in early European history, and which serve in such a clear way to strengthen the contention I am making, the general importance of royal leadership. This minority lasted twelve years under a divided and contentious control, and was characterized by the usual anarchy, intrigues, and family feuds. No victories were gained over the Moors.

This condition of turmoil and retrogression again ceased with the assumption of authority by Alfonso VIII, the Noble, concerning whom we have unanimous testimony of praise, both for his intellectual and his moral qualities. Brave and skilful as a warrior, he was also an astute diplomat. To 
religious enthusiasm he united amiable and generous qualities, and his right to the name of "the Noble" appears to be undisputed. Civil order was promptly restored and maintained during the long reign of forty-four years; the great event associated with his name was the famous victory of Las Navas de Tolosa in 1212, which brought about the virtual ruination of Mohammedan power in western Europe.

With the death of Alfonso the Noble we are brought to a minority of three years' duration (1214-1217). The government was first placed in the hands of the queen-mother, Eleanor of England. She died within twenty-five days. Berengaria, the sister of the young king, next held the regency, but resigned the post in the following year in favour of a nonroyal regent, Alvaro Nuñez de Lara. The conditions under de Lara were insupportable. Violences and injustices were perpetrated on every hand. The clergy, the nobility, and the common people were all sufferers, and it is probable that a rising of the persecuted, which was in progress, would speedily have overthrown the regent had not the accidental death of the young king changed the face of affairs. Since the parts played by the royal women were of such short duration, they can hardly be expected to have established important influences. The good queen, Berengaria, having renounced her claim to Castile in favour of her son Ferdinand of Leon, these two countries soon after became united and were never again separated. The extensive power theoretically established by the union of Castile and Leon then fell into the hands of Ferdinand III.

The military events of this reign $(1217-1252)$ were extremely important. It was then that the two great centres of Moorish civilization, Cordova and Seville, were lost forever to the infidel, together with many of the lesser cities and much of the best of Andalusia. This advance of the Christians was not maintained during the subsequent reign. All things taken together make it seem probable that Fer- 
dinand III was a real genius along the lines of government and warfare.

Alfonso $\mathrm{X}$, who succeeded to the throne, was also a very remarkable character, but an entirely different kind of a man. Being one of the most learned and enlightened men of the thirteenth century, he would naturally be classified among kings of a superior grade were his entire intellectual achievements taken into consideration. He was the founder of Castilian prose and the first monarch of modern Europe who was also a man of letters, the first to see the need of a continuous history of his own country, and the first to unify and codify her laws. Of all men in his kingdom he seems to have been the most interested in science, history, poetry, law, or theology, the one bright intellectual light in a dark age, a man far in advance of his time and little appreciated by his contemporaries. Alfonso the Sage was undoubtedly a man of genius, but like many such was developed on one side only. In all practical affairs he was childish and incompetent: but he was deep and far seeing in science and learned lore. Often likened to James I of England, he appears to have been far more worthy of interest and respect, for Alfonso the Wise was a genuine pioneer. As my object is to trace the wares of national progress and decline on material and economic sides alone, this badly managed and confused reign cannot count as one of advance. It was not, however, marked by any distinct retrogression, such as anarchy and loss of territory. The civil conflict consisted more of threatened revolts than of actual warfare. The continuously bad financial condition was due to debasement of the coinage and excessive taxation. The king spent large sums of money on foreign potentates in a vain attempt to obtain the sceptre of the Holy Roman Empire. On the other hand. the advance in legislation is of some importance. On the whole, the material affairs may be taken as "minus," but certainily no reign in any country can better illustrate the characteristics of a monarch reflected in the conditions 
of his land. All lines of achievement in which the king was gifted made a distinct advance.

The next period (1281-1295), which covers the reign of Sancho IV, is somewhat difficult to judge, as the sources are unsatisfactory and there are some differences of opinion among modern historians. The presumption is that Sancho IV was both brave and active, a king above the average in mental rating though decidedly deficient in moral qualities. He was tyrannical, cruel, and false to his word. There had been a great division of the nation on the question of Sancho's right to the throne, even before the death of his father, Alfonso the Sage. This trouble continued and occupied most of the eleven years of his reign. Sancho triumphed over the opposing faction who wished the crown to pass by strict primogeniture to the son of his elder brother. $\mathrm{He}$ seems to have got the better of the Moors in the few engagements which took place, but the capture of Tarifa on the African coast in 1292 is the only actual acquirement of new territory. Commerce increased, yet the finances remained unsatisfactory. All together, the reign of Sancho IV is not one of importance or decisive trend.

The next period (1295-1302) was a minority, yet the conditions were creditable. All the disturbances which usually accompanied a minority were there in full force, at the start, the difficulties were great both from within and without, but by the end of five years the rebellions had been suppressed and the foreign enemies frustrated. Our vigorous royal personage in this instance was a woman, Doña Maria, the queenmother. She was doubtless greatly aided by the famous Don Alfonso de Guzman "the Good." "The Hermandad, or association of free citizens who had banded themselves together into a brotherhood in 1295 to defend themselves from the depredations of the nobles, were protected by the prudent policy of Doña Maria. Not a single year of her regency was suffered to pass without a regular session of the Cortes. Thus she prevailed over the enemies of Cas- 
tile abroad, and withstood traitors within the realm, not by assassination and tyranny, but by encouraging the party of order and promoting good government at home." 1 But it was only after about five years, and at the close of the regency, that order became established. Thus, for a time, circumstances made themselves more potent than personalities.

About 1302 her son Ferdinand IV became of age, but proved himself a weak, headstrong, incompetent man, much under the influence of his favourites. His moral qualities appear to have been deficient, and we may be at least sure that he was no great man, and also that the reign was one of interminable dissension, revolts, and confusion, in fact, "one of the most disgraceful in the annals of Castile." 2

A divided regency followed, which obliged the country to wait twelve years longer for the coming of a strong king. Civil wars and desolation filled this period. "The central authority ceased to exist, both nobles and towns had to protect themselves as best they could." ${ }_{3}$ Minorities have sometimes been harmful merely because they were minorities; that is to say, the circumstances of the situation gave free scope to rival princes who divided the country in civil wars. This minority appears to be a case in point.

With Alfonso XI (1324-1350) the conditions changed for the better. Many of the lawless grandees were reduced to obedience and their castles razed to the ground. Complete order was not, however, established, but it was the great victory of Salado which gives the reign of Alfonso XI importance in the annals of the Christian recovery of Spain. This battle ranks second only to Las Navas de Tolosa in leading to the final expulsion of the Moors from the Peninsula. Algeciras, which had served as a valuable landingplace for the Moors on their way from Africa, was also captured. The character of this Alfonso appears to bave been

1 Burke.

2 Ibid.

3 Encyclopxedia Britannica. 9th Edition. 
harsh, tyrannical, and licentious, but mentally he is considered a superior man, thus making the twelfth instance in Spain of a good correlation between royalty and the conditions of the country; the two minorities just cited being exceptions.

The reign of Peter the Cruel (1350-1369) may be characterized as one of extreme turbulence. There was an almost continual though desultory struggle with Aragon, the results of which were indecisive. During the last half of this period occurred the civil wars, in which Henry of Trastamara sought to depose his half-brother, the king, - wars seemingly brought about by Peter's own acts of barbarity and folly. Advantages were gained first by one party and then another, until Peter was treacherously betrayed into the tent of Henry, and there slain by the hand of his rival kinsman. The disordered conditions are clearly associated with the actions of the king himself, but the correlation with the strictly intellectual qualities of the king is not so strong; for Peter, though a moral degenerate, was no fool.

Under the reign of Henry II (1369-1379) law and order were soon established, and the enemies of the state subdued. The pretentions of Portugal were successfully opposed. Added to these primary marks of progress there are evidences of excellent legislation. King Henry II of Trastamara is accounted a strong king. Though far from tenderhearted, he appears forceful and active and surely a superior sovereign from the standpoint of mental endowment as well as a successful and indeed a desirable one in those stormy days. He died in 1379, leaving his kingdom in peace to his son John.

The favourable turn of affairs did not, however, continue under the son. The reign is signalized by unsuccessful warfare with the Portuguese, the most notable event being the battle of Aljubarrota in which the Spaniards were severely beaten, and the independence of Portugal substantially secured. In other affairs no changes are to be noticed. John I 
was a man of inferior mental capacity in comparison to the majority of kings, though, perhaps, his intentions were good. He suffered from bodily infirmity, which interfered with his success as a soldier. His disposition was mild and amiable, and he is accredited with a generous and a just nature.

Henry III, his son and heir, was a mere lad of eleven at the time of his accession. The government was placed in the hands of a council and the usual events ensued, - discords in the court, civil warfare, and general disorder. Henry developed many strong qualities as he grew to manhood. From the time he was twenty years old until he died aged twenty-seven, in 1406, the period shows the greatest contrast to the embroiled and retrograding minority. Not only was internal order restored but wise laws were enacted which served to restrain the rapacity of the judges and bring many unjust tax extortioners to account. Henry was essentially a diplomat, and did not neglect to strengthen his foreign relationships. All praise was given the young sovereign, and all, save the lawless, lamented his early death.

Fortunately the regency for young John II (1406-1416) came into the hands of a prudent and able man, Ferdinand, uncle to the king, who ruled ten years with signal success. This favourable state of affairs did not last long. The young king, in contrast to his uncle, had almost no qualities suitable for leadership. Though possessed of some accomplishments and fond of literature, John II was so lacking in ambition, force of character, and practical insight, that he must rank among the weakest of royalty. It is said that on his deathbed he lamented he had not been born the son of a mechanic instead of a king of Castile. The business of government was under the dictatorship of Alvaro de Luna, and his work was very pernicious indeed. The long reign is nothing but the story of intrigues and disturbances, meaningless civil wars, and occasional inroads by the Moors.

Castile continued to decline under John's successor, Henry 
IV (1454-1474). In fact, the conditions were even worse. Henry was "weak even to helplessness" and "addicted from his earliest youth to debauchery." He was indolent and cowardly, and altogether a pitiable specimen of a king.

After some sixty years of retrogression and disintegration a great change came over the land. A country which a few years before had been but the wretched arena of internecine warfare and selfish struggles soon appeared among the great powers of the world and took a leading part in the important events of modern history. Both externally and internally there is here an abrupt and remarkable transformation. We know that Isabella came upon the throne of Castile in 1474, and almost at once and before the union with Aragon in 1479 establishment of law and order and improvement in the finances marked her accession. We know that all historians of that time, or of our time, agree in considering Isabella a remarkable personality. How can we conclude otherwise than that it was the advent of this woman that constituted the prime cause of the change? It is not likely that after sixty years of darkness and decline, the complex interplay of forces, which we call circumstances, should happen to be favourable again, and that these same favourable circumstances should chance to occur just at the same time that a new ruler came upon the throne; and then furthermore, that these circumstances should continue to happen to be favourable cach succeeding year.

A certain amount of union existed between Aragon and Castile after 1479, and from this date one may conveniently treat of both countries under the name of Spain; but before tracing the more massive outlines it is necessary to go back to the early history of Aragon and bring this down to 1479 and see if the lesson from Castile is supported by the annals of its neighbour. Castile furnishes twenty-four periods of sufficient historical clearness for the purposes of this study. Twenty-two of these show an almost perfect correlation between the characteristics of the royal leaders and the polit- 
ical and economic changes. It is to be observed that this correlation is almost invariably associated with the mental rather than moral qualities. In the reign of Peter the Cruel alone is the decline associated with moral defects. Two of the minorities were filled with conflict and disruption, with retrograding movements which seem the result of moral deficiencies (overambition and lack of patriotism) on the part of those high in the councils of state. It is to be noted that the correlation is as high in the first half of Castile's history, the first twelve periods, as it is in the last twelve, thus indicating that there is no great tendency for the historian of the earlier and less authenticated period to overpraise and overblame the kings. This does not prove the entire absence of such a tendency, but it suggests the factor of error from this source is slight and not one to seriously invalidate the conclusions. It goes towards proving that the estimates for the earlier kings are not so very far out of the way, even if they are necessarily based on scanty material. 


\section{CHAPTER V}

\section{ARAGON}

THE history of Aragon as an independent kingdom begins in 1035, when Sancho el Mayor divided his extended possessions among his several sons. Aragon, at that time but a weak and unimportant territory within narrow confines, fell to the bastard Ramiro. The next hundred years comprised the reigns of Ramiro I, Sancho I, Peter I, and Alfonso I. Each of these periods is signalized by important victories over the Moslems and an almost constant growth in the area governed by its kings, each of whom is described as a vigorous character, - bold, ambitious, and enterprising.

After a century of progress, events occurred of a three years' duration which are very suggestive. Alfonso I, called the Battler, died in 1134. Before the end of 1137 Navarre had thrown off the Aragonese yoke, and Castile had won back from Aragon the best cities which she had previously lost. The "Empire," so-called, which Alfonso and the previous kings had formed, fell immediately. We may not know for a certainty that the new king, Ramiro II, was, as the historians pictured him, a modest, unambitious person of little courage or cleverness, but we do know that he had been a monk, and that in three years he retired again to a monastery. If we conclude that he really was, either by training or nature, unfitted to the task of kingship, and that this sudden break in the continuity of Aragon's growth was a question of personalities, then we can understand all the connected facts. But if we ignore or depreciate in any way the force of personalities, we cannot then explain why 
this brief retrogression occurred after a century of progress, just at the death of Alfonso I in 1134.

After the voluntary retirement of Ramiro the Monk, Raymond Berenger of Catalonia exercised sway over Aragon by right of his wife, Queen Petronilla. This reign and the next were very successful, gave sixty years of victory and growth, while the whole of Catalonia was permanently freed from Mohammedan control, and many important cities were taken in the new territory to the south. Both Raymond Berenger and his son, Alfonso II, were considered strong and able leaders.

The years 1196 to 1213 brought no suecial prosperity or progress and no marked deeline. Peter II is clearly delineated by historians as a romantic, impulsive character with the virtues and vices supposed to be associated with the age of chivalry. He was not a great king in any sense. His reign also belongs in a grade between mediocrity and weakness.

In the year 1213 Aragon arrived at her second retrograding period, the first since about seventy-five yours before, when the monk Ramiro sat for a short time upon the throne. We know that the serond period, just as we know that the first, or Ramiro, period, was a distinct pause in the onwarel march of a nation which afterwards carried its name and influence to every quarter of the world. We also know that in the first case a monk unberomingly held the sceptre, and in this second case a regency existed, the power being divided between screral of the nobles. Now we may not be as absolutely assured that all our characterizations of early peninsular sovereigns are correct, lrawn as they have been from estimates based ultimately on the early chronieles; but we can here see that the logical supposition is that the so-called weak kings really were weak, and, vice versa, the strong ones strong, and if we so assume them, then we can in that way satisfactorily fit all the facts together, both those well known and the less well attested.

The young king early showed promise of exceptional 
qualities and very soon took matters into his own hands. He became one of the most celebrated figures in early Spanish history, and is generally known as James the Conqueror and stands out both physically and mentally as a giant among his subjects, - a Teutonic type of hero, tall, fair-haired, impetuous; generous or cruel, tender-hearted or sensual, as the mood impelled, but always a king among men. James the Conqueror was also a pioneer in the literature of his country, and wrote a valuable chronicle of his own times. He and his son Peter III, called "the Great," are the two sovereigns of Aragon whom any one would pick out as the foremost. They reigned from 1228 to 1285 , covering the period of most important conquests, legislative, financial, and commereial progress which this country made at any time from the beginning of its eareer until the union with Castile in 1479.

Alfonso III follows this heroic era with a short and colourless reign (1285-1291). He was a very young and presumably inefficient person, about whom little is known. The fact that the Cortes increased in importance, through the Privilege of Union in 1287, must not be overlooked.

Again, in the administration of James II, eame a time of relative progress, as is attested by the peaceful and prosperous conditions at home. Foreign affairs in Corsica, Sardinia, and Sicily are not so easy to determine. The king himself was probably above the average in ability. He was called "the Justice." It appears that an excessive penchant for vice and debauchery caused him to renounce the throne before his death. Then follows nearly a decade under the feeble Alfonso IV, which is characterized by no advance and no very notable decline. Aragon's commerce suffered from war with Genoa, which brought to either of these maritime rivals nothing but wasted fury.

From 1336 to 1410 we find a long series of contrary currents, and it is not quite clear which way the stream flows. Legislative advance, commercial decline, wars both suc- 
cessful and unsuccessful, chiefly over Sardinia and Sicily, island conquests, which were the chief concern during this era, make, on the whole, a doubtful trend. Peter the Ceremonious, John the Careless, and Martin the Humane held sway. The first of these was vigorous, the second weak, and the third mediocre. Though the parallelism here between the king and country is not perfect, there is no departure of any significance. On the death of Martin the Humane in 1410 , two years of decline set in, characterized by civil warfare, internal disorders, and troubles in sicily. It was an interregnum.

Ferdinand I established peace and order during the short reign (1412-1416), and this is the same vigorous prince who, as regent of Castile, showed that a minority need not be a period of decline. Again we have a long course of doubtful conditions, very similar to those between the years 1336 and 1410. Too much attention was given' to Italian affairs and conquests outside of Aragon; the best interests of the home country suffered in consequence. It was, however, far from being a period of decline, and was under a comparatively superior king, Alfonso the Magnanimous. John II, another strong king, closes the list of Aragonese rulers, with twenty-one years on the side of progress.

The correlation between the personnel of the Aragonese monarchs and the deviations in the conditions is very high indeed. For twenty-one periods there are no deviations which oppose each other, - i.e., ruler "minus," conditions "plus," or ruler "plus," conditions "minus," - and there are only three or four instances when the symbols of the two columns fail to parallel each other exactly. As in the case of Castile, the earlier half is no more made up of high correlation than is the latter half. 


\section{CHAPTER VI}

\section{SPAIN}

No chapter of history opens more gloriously than that of united Spain. Every one knows something of the reign of the famous Ferdinand of Aragon and the still more celebrated Isabella of Castile, - the conquest of Granada which meant the final expulsion of the Mohammedans from western Europe, the entrance of Spain among the powers, the beginnings of that growth in commerce and increase in wealth which followed the discovery of the new world. This era has been a favourite topic for historical research, but time has not diminished, in the perspective of the ages, the eminence of los Reyes Catolicos, who still dominate the panorama from every point of view. Ferdinand, whatever his failings may have been, was one of the cleverest statesmen of his age, and Isabella still stands among the great women of all time.

The death of Isabella was followed by a brief period, about a year and a half in duration, which, though not important in the totality of Spanish history, is suggestive nevertheless of what is probably a constantly recurring factor of some importance in ancient, mediæval, and to a less extent in modern, history. It is reaso nable to suppose that, generally speaking, the death of a strong sovereign is in itself an event predisposing towards disorganization and retrogression, even when this ruler is immediately followed by another of equal ability. It gives occasion and hope to the malcontents. One must believe, from all the facts, that the duration of such a condition has been determined chiefly by the qualities of 
the new ruler, but a certain amount of upheaval might naturally be expeeted before the new man had time to assert himself.

Here is a case in point. Isabella was followed in Castile by the able Ferdinand, who was to aet as regent for their daughter Joanna. A year and a half of unsettled political history was followed by the resignation of Ferdinand in favour of his son-in-law, Philip. This relinquishment was, aecording to Prescott, aceeded to by the regent "to extract himself from his perilous position and shield the country from the impending evils of a civil war." If Ferdinand had continued in power long enough, it is fair to suppose that he would have overome the exeited opposition. Subsequent events would lead us to conclude as much. However that may be, the inexperieneed and light-brained Philip was given a chance, but in two months he was out of it again. His reign was as disgraceful as it was brief.

Conditions were growing steadily worse when in $\mathbf{1 5 0 6}$ Ferdinand was again, and this time permanently, given the regency, which office he brilliantly filled for the next ten years. As usual, the form of investiture of power counts for little, the personality for much. "Before him insurrection quailed, the laws resumed their empire, and prosperity revisited the people." Both commeree and agrieulture made excellent progress, but of greater interest is the commencement of that lordship over foreign lands which was to give Spain her wide, though transient, world power. This uplift continued without interruption until the death of Ferdinand in 1516, when a year of doubtful signifieance ensued under the non-royal regent Cardinal Ximenes. Perhaps this brief term should be counted on the side of progress. At any rate, Ximenes was a great and remarkable man, and it should be noticed how few of his mould Spain ever produced except from royal stock.

Granting this regency as one of possible exception to the rule, we arrive at the date 1517 , which begins the important 
forty years' reign of the Emperor Charles V. This was the golden age for Spain in many ways, and in connection with the reign of his son, Philip II, covers nearly the whole of the sixteenth century, and carries us up and just a little over the crest of the wave of Spanish preëminence. Although these two reigns have been generally considered of unusual interest, they are not especially instructive in a bald and systematic comparison of conditions with sovereigns. The reason why these two reigns are not interesting in the present research, is because neither one of them is a clear case of progress or of decline. If the conditions should be split up into their strong and weak aspects, doubtless much sovereign influence could be rendered probable. Therefore there is really more monarchical influence at the present point than the systematic method which I am pursuing is able to bring out. As I have said all along, the method only pretends to measure approximately the lower limit of the personal influences.

The decline which was clearly manifest during the latter days of Philip II increased its pace enormously under the third Philip. The fourth of the same name saw matters go from bad to worse, while under Charles II (the last of the Hapsburgs) national demoralization reached its limit. The seventeenth century is synchronous with these four reigns, which are so much alike that a hasty composite of the four will serve as well as a detailed account of each. In fact, the the word "decline" covers the story of the material affairs in every department. As for the rulers, the single epithet, "weak," will suffice.

The notorious retrogression of the Spanish monarchy during the seventeenth century has been very extensively investigated. The warfare of that time has been fought over again in the controversies of historians, but no one denies the main fact that Spain did decline. The quarrel comes over the proportional share of the various causes. The following is a partial list showing the variety of causes 
assigned by different writers, each usually bent on emphasizing his own explanation:- depopulation on account of emigration to the new world, evil legislation relating to industries, laws against the exportation of gold and silver, revolt of the Netherlands, importation of negroes in the colonies, cost of the wars of Charles $V$, great power of the Church, "too much gold and too little liberty had demoralized the race," establishment of the Inquisition, expulsion of the Jews, heary taxes imposed on the mines in the new world, brutalizing tendency of the bull-fight, disaster of the Spanish Armada.

That most of these supposed eauses were really contributory to the general debacle is certainly a reasonable assumption, but the personal weakness of the sovereign is generally overlooked, and furthermore nearly all these injurious forces may well be directly traceable to royal initiative, - to the pernicious policies of Charles $\mathrm{V}$ or Philip II, not corrected under their degenerate successors. I do not claim that the unusual appearance here of four weak rulers is a more powerful eause in bringing about the downfall of Spain than the other causes taken together; but I do claim that we have here, by the comparative method, scientific proof that it is an important cause (while the acceptance or rejection of the other causes is gratuitous, in the present state of knowledge) and also that the other above-mentioned causes may have arisen from the mental defects of the kings.

As a result of the War of the Spanish Succession, Louis XIV of France established his grandson, Philip V, upon the throne of Spain. Conditions, though not satisfactory under this prince, were so much improved in comparison to what they had been under the last four Hapsburgs that we must count the reign in the "plus" direction. Philip was a weak and indifferent character and finally became insane. Such reforms as took place were initiated by the prime ministers, who were French, Italian, and Dutch in origin, and who were sent into Spain by Louis XIV. Here is an instance of prog- 
ress under a weak king, but the statesmen who directed the movement were not born in Spain.

In the history of the next reign one finds a rare instance of a king of mediocre, or perhaps inferior, capacity exercising a very favourable influence through a sincere desire for the welfare of his subjects. Ferdinand VI was called "the Wise," and he seems to have been both prudent and enlightened; but he became insane, and this may have something to do with the inferior rating which some historians give his intellectual capacity. The reign was peaceful, and reforms took place in agriculture, manufactures, commcrce, and the finances. The Marquis de la Ensenada was prime minister, and in him Spain enjoyed the third instance of a native Spanish statesman devoted to the best interests of his country.

The reign of Charles III was also successful. Charles III was himself a very superior ruler. Without being exactly brilliant he was generous, just, and enlightened, with a sound judgment for practical affairs. In connection with his ministers, de Aranda and Florida Blanca, an administration was given to Spain which brought improvement into every department of the government. Not only in military, financial, naval, and diplomatic affairs, but also in agricultural, commercial, and industrial life, solid advances had been made when Charles III dicd in 1788.

This is the last reign which can be discussed without becoming involved in the Napoleonic period with its gigantic political changes, which depended on a personality so great as to upset all the usual fluctuations in the evolution of nations. Thus the greater part of the eighteenth century gave a better promise in Spain than the nineteenth realized. There was a perceptible improvement during the reigns of Philip $V$ and Ferdinand VI, not readily ascribable to the kings themselves. But aside from this the whole history of more modern united Spain is not much different from ancient Castile and Aragon. Fourteen periods show only about four points of deviation 
from almost absolute correlation between sovereigns and conditions. Three of these four are associated with the names of exceptional statesmen (prime ministers), only two of whom were of Spanish birth. The history of spain bears a very strong similarity to the history of Portugal. There is no evilence anywhere of gradual cumulative parliamentary development, although all these peninsular countries, Castile, Aragon, Catalonia, Valencia, Navarre, and Portugal, had a very early start in representative government. The steps in the direction of constitutionalism came uncler strong not under weak kings; and it is a profoundly signifieant point that neither the nobles nor the commons were able to organize and make aipital out of the weaknesses of their kings. 


\title{
CHAPTER VII
}

\author{
PORTUGAL
}

THE history of Portugal has never been given the attention it deserves. Not only is the period of discovery and conquest an almost continuous epoch of expansion, replete with dramatic interest, but the long decay which this country underwent throws the second half of its history in vivid contrast to the earlier. Thus a splendid problem is presented in the field of historical causation. The Portuguese were the pioneers in modern geographical exploration. They prepared the way for the diseovery of America by systematically pushing forward the art of navigation and penetrating the limbo of the South Atlantic, - "the sea of darkness" of the ancients. They were the first to open up the sea route to India ; they were the initiators of the permanent colonial policy of Europe and the first to shoulder the treasure that comes with the "white man's burden." Lisbon was the city, of all eapitals of Europe, for life, adventure, intrigue, and profit, for one generation of men; and the king of Portugal (Emanuel the Fortunate) the richest and most influential monareh in the world.

The rise and fall of Portugal follow very closely the personnel of the monarchs; no more so than most nations, but more noticeably so than some, because here nearly all the early monarchs were strong while all the later were medioere or weak. Indeed, it was while investigating the history of ancient Portugal that I first hit upon the idea of monarehical influence, and that it might, on account of its evident importance, be made a first or central foree in historical measurement. The account which I have already published 
(Chapter XII of "Heredity in Royalty") need not be essentially altered, though a more extended reading has shown three or four estimates that require readjustment. The history of Portugal has been studied by so few people in England, America, France, and Germany that it is not possible to get adequate information except by going also to the Portuguese writers themselves. Not that the easily obtained information is so faulty, but it leaves much to be desired, because it is so meagre. I have personally collected some twelve hundred books and pamphlets, mostly in Portuguese, dealing with the heroic period, and so have gained some insight into the value of the sources.

It seems to me that one's opinions and judgments change more and more on minutia and less and less on essentials as one's studies extend from the usual towards the unusual, from the encyclopedias towards the Mss. The minutiæ seem more and more as if they were essontials, but this comes from a narrowing of the field of vision. As soon as one expands that vision again - as indece one must expand it if a broad problem be the goal, a problem covering several centuries of time - then the details vanish into an insignificant haze. The rigorous insistence of historians upon accuracy of detail is thus explained. As they work upon each segment of the historical curve they demand aceuracy for all the points upon that segment, an accuracy which is important if taken in terms of the size of segment, - that is, in relation to a brief duration of time. On each of the segments they devote the same accurate care. Having devoted so much research to each section of the country's history they thus grow to genuinely love each period separately, and will not endure the least tarnish of what they believe the truth. They do not then realize that if they would stand back far enough to see the general form and direction of the curve the minutiæ would become of very little importance.

In the history of Portugal one runs across a number of 
old legends now expurgated from the more critical modern accounts; but the remaining facts (or alleged facts if one likes) fit just as well into the theory which I am setting forth.

Some of the changes and additions which $I$ should wish to make were I rewriting the whole chapter would be the following: Sancho II (1127-1245) was not altogether so "weak and lazy," nor was his reign devoid of a progressive side. The reign of Ferdinand (1367-1383) also contained one important element of progress, - growth in the mercantile marine, - but there is nothing to off set the disruption in the government, decadence in agriculture, and a wretched fiscal policy. Ferdinand himself was lazy, frivolous, and soft, - distinctly below the average. On the other hand, I have taken John I too high. John I, the Great, so-called, was not exactly a genius, rather a man of gifts and judgment. He was undoubtedly aided by circumstances, by a popular movement, by his famous lieutenants, and perhaps chiefly by his own family. The period 1384-1433 which marks the beginning of Portugal's participation in the Renaissance is not much understood. At any rate, it was an era of prosperity, and John I, though probably not deserving the epithet "great," is at least worthy of being graded here as "plus."

Emanuel, often called the Fortunate, probably deserves much more credit for the direction of events during the culmination of the "heroic period" than the majority of writers have heretofore given him. The great discoveries were initiated by Prince Henry the Navigator, supported by the regent Dom Pedro, and furthered by John II, so that on the accession of Emanuel in 1495 the Cape of Good Hope had been rounded and preparation had already been made for the voyage of Vasco da Cama. Portugal's favourable maritime position and the training in seamanship which her people had long enjoyed were undeniably contributory to her great bonança; but if the fluctuations in the expansion in maritime discovery be considered, the personal influence comes again to the fore. 
That the systematic explorations under Henry the Navigator were really due to his own initiative and persistent direction is shown by the way exploration languished after his death. Alfonso V, always bent on crusading in Africa, neglected exploration. Only a comparatively small strip of new coast line was discovered between the death of Prince Henry in 1460 and 1481, the close of Alfonso's reign. John II (1481-1495) took up the work again and geographical knowledge augmented with renewed activity. It is not too much to say that the greatest single series of events in the geographical rearrangement of mankind, the discovery of half the world by the other half, would have been retarded many years had the heroic Portuguese princes (true Vikings in their blood and in their nature) never indeed existed.

From 1521 to 1788 not a single strong king fell to the lot of Portugal. Philip II of Spain (I of Portugal) cannot awaken our enthusiasm. The only ruler to claim rank with rulers surcly mentally superior would be Louisa de Guzman whose influence lasted from 1640 to 1662 . She must be rated very high among princesses, not so high among actual rulers, as their average standard is higher.

The only notable progressive period during all these generations of national demoralization was that under the Marquis of Pombal, the only man of genius to rise to the needs of the times.

The last half of Portugal's history is, just about as much as the first half, correlated with the character of her kings. Therefore, there is evidence that the early chroniclers were not so far out of the way after all. 


\section{CHAPTER VIII}

\section{THE NETHERLANDS}

Groningen, Friesland, Drenthe, Overyssel, Guelderland, Utrecht, North Holland, South Holland, Zealand, North Brabant, and Dutch Limburg are the names of the several provinces which lie north of Belgium and west of the Rhine, and to-day form the independent political entity known as the Netherlands, sometimes less correctly called Holland. South of these lie the provinces of Antwerp, Brabant, East Flanders, West Flanders, Hainault, Liège, Limburg, Luxembourg, and Namur which constitute the various elements of the kingdom of Belgium. Although the geographical significance attached to the names of these provinces has remained fairly constant, the political meaning of the term Netherlands, Pays Bas, or Nederland has often changed as the provinees have been united, separated, and united again in shifting combinations. Under Charlemagne all formed part of his vast empire. After the death of the great Emperor, there took place a parcelling out of minor territories according to the custom of a feudal age, so that many small countships and duchies became hereditary in the families of a new nobility. At the same time the cities achieved an early independence, and the vigour of their growth already indicated the quality of the commoner with whom the noblemen had to deal. From the beginning of the eleventh to the end of the thirteenth century, a strong line of counts of Holland aided in the development of the northern portion of the Netherlands. After the year 1299, a change took place, and the long struggle between Zealand and Holland seemed to paralyze the national life. 
It is not until Philip "the Good" appears upon the scene that the various territorial elements of the Netherlands are sufficiently united to constitute an important political aggregate, - a kingdom suitable for comparison and study side by side with other European nations.

Philip "the Good," so-called, of Burgundy, inherited Flanders and Artois from his mother. He bought Namur, seized Brabant, Antwerp, and Limburg. He laid claim to the inheritance of the northern provinces also, and his efforts in this direction were no less successful. Jacoba, the last heir of the old house of Hainault, was compelled to cede her rights over that territory as well as the counties of Holland, Zealand, and Friesland. Thus Philip of Burgundy became one of the most important sovereigns in Europe, chiefly because of the value of the Low Countries, which at that time could not be matched for the wealth of their manufactures and commerce. This was the beginning of the unification of the Netherlands. Two generations later they passed en bloc to the house of Hapsburg by the marriage of Maximilian with Mary of Burgundy. They continued to be united two generations longer, until the northern provinces, under the leadership of William the Silent, formed themselves into an independent republic known as the United Netherlands. The southern provinces remained a dependency of Spain.

At this parting of the ways I shall follow the fortunes of the northern division, because these formed a nation politically autonomous and these provinces represent virtually the same geographical area now included in the kingdom of the Netherlands. During a short period only, this summary must also treat of conditions found in the territories now called Belgium and Burgundy. Although the northern provinces were for a time theoretically a republic under stadtholders of the house of Orange, there seems no good reason for breaking the continuity of the tabulation on this account, even though it be my purpose to measure the 
influence of royalty. The princes of the house of Orange were virtually kings. Their origin, if not strictly royal, was nearly so. Their marriages were either with the most important noble families of that part of Europe, or with actual reigning sovereign lines. The title is nothing. The point is, that they formed a dynasty of rulers (stadtholders) allied by blood with other dynasties of Europe.

There are three periods when this quasi-royal line became broken. A republican form of government fills in three gaps which occupy the years 1650 to 1672,1702 to 1747 , and 1759 to 1776. Thus opportunity is afforded to see how well or how ill this portion of the world could carry on the experiment of taking care of itself without the royal leadership. Such definite republican interludes occurring in governments, for the most part monarchical, are of the highest value in a negative way to one interested in measuring the potency of the kings themselves.

Returning to a view of the Netherlands at the time of Philip of Burgundy (1419-1467), one sees a very flourishing state of affairs, a condition which had persisted in a general way for a number of centuries. Trade, commerce, fisheries, and the arts of fabrication here made an early start. There must have been a very high level of intelligence and industry in the make-up of the middle classes all through this section of Europe. Even from earliest historical times, a broad distribution of wealth had been enjoyed. Here the towns and cities soon achieved importance and independence. Not many nobles ruled over wide estates, or illustrious warriors conquered and built regal power at the expense of their neighbours and rivals. It is true that the nobility remained an important and powerful influence within its home limits, but there were no great governing families prior to the Burgundian rule, - nothing to be compared with the Plantagenets or the Hohenstaufens, or the sovereigns of Castile, Aragon, Portugal, and France.

Although Philip "the Good" of Burgundy found the Low 
Countries in a thriving condition, it is very certain that he left them even more so, and that these provinces derived much benefit from the astute policy which characterized the activities of this ambitious prince. Philip was called "the Good," an unfortunate epithet which every historian takes pains to notice. It is my general impression that the appellation which monarchs have received, given first by their contemporaries, and conserved through the ages, are usually very fair summarizations of their traits ; but Philip of Burgundy was not "the Good." He was a crafty, self-seeking tyrant who crushed the liberties of the people and overrode every one who came in his way. He had his good points, however; one of them was a genuine appreciation for the fine arts, which led to something far more important than mere luxurious display or pompous court functions. Philip le Bon always demanded and obtained the best, whatever the object might be, - a neat little fertile province or priceless altar-piece. One cannot help forgiving much to the man who patronized the brothers Van Eyck, founded the wonderful Burgundian library, and aided in so many ways the establishment of the early Flemish Renaissance; but these developments belong to a side of history that I am not attempting to discuss.

It is on account of the immense impetus to the industrial and architectural arts which this connoisseur-monarch gave, that his influence became important in its relations to strictly material matters. More and better public buildings, richer and more costly garments, paintings, statues, or books, belong of course in part to, and are indications of, material wealth. This side of history, during the reign of Philip, has a fine rare glow, with an atmosphere of alluring colour, - an aurora which reached for the first time the shores of western Europe. The loss of political and personal liberty which the commoners were forced to endure does not seem to outweigh, at least from the material standpoint, the many advantages which the Netherlands gained under this master tyrant. 
Philip was very clever in the diplomacy of his day, and cunningly played England against France: He constantly resisted Frederick III and the Holy Roman Empire, and had hoped to found a great and independent kingdom from Burgundy to the North Sea. The treaties which he brought about were favourable to the provinces and were followed by a marked increase in commerce and manufactures. Agricultural development was aided by a wise management of the dikes, - the building and care of which was naturally a most important department of public works. Not only was the financial position of the government strengthened, but the increase in wealth enabled the people to bear the heavy taxation with comparative ease, so that one contemporary author supposed that they were in fact more lightly taxed than the subjects of other princes. Philip le Bon never quite gained the ambition of his life, but he became at least a king in all but name; and certainly, in wealth and magnificence, outranked the king of France and the Holy Roman Emperor. Before and after the fall of Constantinople, it was Philip of Burgundy to whom the Pope and the western princes turned, when the repeated conquests of Mohammed II drove Christendom into hysterical fear. Neither Burgundy nor the other western powers offered much assistance when the crisis came; but the fact that Philip was looked upon as the natural champion shows that this prince had raised himself to an extremely exalted position. It would not be too much to say that from the strictly worldly standpoint Philip "the Good" was the ablest practical man of his own generation. A few more like him in the Burgundian line and there might have been no France, so-called, and we should to-day be reading in its place the history of Burgundy.

The majestic plans of the father for forming a great Burgundian kingdom were destined to be shattered by the career of his rash and impetuous, though brilliant, and in all ways interesting, son Charles. The epithet le Téméraire 
is usually translated as "the Bold," but it might, with better judgment and iner linguistic propriety, be rendered as "the Rash" or "the Foolhardy." Charles le Téméraire was no fifteenth-century diplomat. Louis XI of France was, and herein lay the difficulty for Burgundy. European politics were lashed into the maelstrom which finally ingulfed the Burgundian interests by the sinister and green-eyed conjurer of France, - that master of the fine art of dealing with enemies. It was a mighty duel between France and Burgundy, but it was, as even their contemporaries saw it, a battle between "the French spider and the Burgundian lion." The methods of Burgundy were as different from those of France as were the tempers of their potentates. Charles was always frank and chivalrous, impetuous and above deceit, grand and quixotic, self-reliant and beyond restraint. He fought valiantly for his life's idea, the reincarnation of the ancient kingdom of the Carlovingian Lothaire, which he would extend from the North Sea to the Mediterranean, and interpose a broad belt between France and the Empire. This was also the policy of his father, the foundation stones of which had been laid by his grandfather and great-grandfather. It is but little remembered to-day how near the Burgundian came to the realization of this dream. Philip the Bold, John the Fearless, Philip le Bon, and Charles le Téméraire all worked successively for a grand Burgundy. Charles overreached the mark and tried to accomplish everything at once; he had, furthermore, in Louis XI an extremely astute man to outwit, while his forebears had only the insane and weak Charles VI and the mediocre Charles VII for French opponents.

Still it is a question if the Netherlands, which form the true geographical region whose fortunes are the theme of this chapter, really lost more than they gained during the era of Charles the Rash. There is much to be said on the favourable side. Though the many wars were expensive and brought no advantage to the Low Countries, it is doubt- 
ful if the heavy taxes were borne with any great difficulty. The seat of action being chiefly in Switzerland, the Netherlands were left free to develop their own trades and industries; and the vigorous rule of Charles made impossible any chronic and bloody conflicts between the opposed political parties at home, - the Hooks and the Cods. During this reign the already flourishing eities grew in wealth and importance. The fisheries, however, suffered from interruptions and seizures oceasioned by French ships of war which Louis sent to the northward. But even this side of industry, if we are to accept the more modern view of Wenzelburger, progressed rather than declined during the days of Charles the Rash. It is but natural that the burgher classes should find their pretensions strongly opposed by such a dominating master, and that retrogression in political liberty should be the order of the day. As far as this goes, we must admit a backward tendency; but, all things considered, it would seem that the years 1467-1477 were favourable to the Netherlands.

It was otherwise with the fortunes of Burgundy. This country reached the apogee of its power about 1469, lost ground under the reckless career of its last duke, and when the naked body of Charles was taken from the iey shore of a Swiss lake, the last act of the Burgundian drama was over. The tragic death of Charles the Bold eaused a profound sensation throughout Europe. All anxiously awaited the fate of a country left without a master or male heir, and discussed the young and still unwed Mary, the sole inheritor of the wealth of Flanders and Holland. Would Burgundy and its attachments swing to France or towards the Empire? Eventually Mary married the young Maximilian, and so the house of Austria rose at once to the highest pinnacle of power and the history of the Netherlands became interwoven with the lives of the Hapsburgs.

Mary's rule was brief. She died five years after her father, in consequence of a fall from her horse; but already time 
enough had elapsed to show the effect of transferring the control of the government into the hands of a weak and inexperienced woman. "The internal dissensions in Holland which the iron hand of Charles had crushed for a time, again grew rank after his death, and the two parties of Hooks and Cods renewed their persecutions of each other with a rage and bitterness that reduced Holland to a state of extreme bitterness and desolation." The naval power of the Dutch also suffered a severe blow during this period, losing very heavily in conflict with the French. On the other hand, political liberty (whatever that may be worth) must be weighed on the other side of the scales. It was then that the "Great Privilege" or "Groot Privilegie" was founded. This restored parliamentary rights, gave the cities and provinces a voice in the government, especially in the levying of taxes and the declaration of war. Although in practice the Great Privilege soon fell in abeyance, and remained ineffectual for nearly a century, it is important as expressing the basic principles on which the Dutch republic was afterwards founded. The "Great Privilege" of 1477 is also interesting because it shows that the people of the Netherlands were, for once, able to take adrantage of a weak sovereign and obtain political advance by combined effort. It is difficult to weigh the value of the Creat Privilege against the internal commotion, so the reign of Mary of Burgundy has a doubtful entity.

Maximilian of Austria, husband of Mary, acted as regent for the Netherlands from 1482 to 1493 , a period of turbulence and decline. Maximilian was a strong character, or at least in after years proved himself to be, but there is little in his regency over the Netherlands to demonstrate royal efficiency. The only thing to be said in his favour is that in the end the rebellions were suppressed.

The reign of Philip the Handsome (1494-1506) was equally contradictory, though in precisely the opposite way. Philip was merely a pretty figurehead, never an important force. 
His country, however, enjoyed a distinctly progressive interval during the twelve years of this administration. In 1494 the states lost the Great Privilege, but this did not make any real difference. There had never been any good results from the democratic movement, experimentally shown to be a failure under Mary and Maximilian. The chief glory was a commercial one. Holland and Flanders were growing. Trade, especially with Spain and Portugal, forged ahead. Here much credit is due the people as a whole; good order was preserved and rival parties kept the peace. After the premature death of Philip the Handsome (1506) Maximilian again became regent and a year later this official position was relegated to his daughter Margaret.

For the next two generations, it is impossible to separate the rule of the emperors from that of their relatives, who, as special regents, were appointed to govern the Low Countries. Fortunately for the method here employed, this does not introduce any confusion, for the reason that both the emperor and the regents were definitely above the average; so when both are added together the composite must also be superior or "plus." Maximilian, Charles V, Margaret of Savoy, Mary of Hungary, and Emanuel Philibert of Savoy, together form a very strong group. Special consideration must, however, be taken of Philip II of Spain, whose influence begins only at the close of this cra. Philip II is an unusually difficult person to place satisfactorily in any scheme which distributes historical characters into grades for intellectual eminence. The case of Philip II will be given more detailed attention later. As far as the others are concerned, it will suffice, in a hasty survey like the present, to point out that coincident with this array of royal talent occurred il season of great productivity throughout the Low Countries. ${ }^{1}$ The

I I do not say the royal initiative produced this lively upgrowth, doubtless many eauses contriluted; but I do wish to emphasize an insufficiently observed phenomenon, here, as elsewhere, impossible to measure in its isolated occurrences; but by its frequeney of repetition compelling the recognition of 
more or less combined and interdependent government of the emperors Maximilian I and Charles $V$, with the regents Margaret of Savoy and Mary of Hungary, covers fifty years, and the era comes to a close with the abdication of Charles $\mathrm{V}$ in 1555. As far as the Netherlands are concerned, there can be no doubt but this age was one of great prosperity. All strictly material affairs joined in the forward movement. All such features of national life as industry, trade, agriculture, fisheries, finances, coinage, house-building, as well as the subtler forces which make for international prestige and importance, are found progressive. Antwerp became the first commercial city of the world. Ghent was so large and wealthy that the proud Charles declared jestingly to Francis I of France, "Je mettrais Paris dans mon gant." There is not much to say on the other side of the question except that the people were governed with rigour, and popular liberty necessarily suffered. It may be contended that by this beneficent tyranny the way was paved for the later atrocities, and the control of Philip II and Alva. Such may be the case, but even if the loss of political liberty be thought to outweigh the commercial and material advance, it does not alter the fact that the whole history of the Netherlands during this epoch is just what might be expected as an outcome of the management and expression of the characteristics of three or four people who were in the chief control.

Philip II at first appointed Emanuel Philibert of Savoy as regent for his Dutch and Flemish possessions. This distinguished prince did not continue in office except for the first few years (1555-1559). There were no important changes during his administration; but one sees the smouldering discontent and hatred toward the Spaniard which afterwards culminated in the great struggle for Dutch independence. The hand of Philip II is everywhere to be seen. His regents its own importance, not only as an abstract generalization but also for this concrete case. 
carried out his policy and formed a part of himself, an accentuation of that mysterious personality housed in its austere Spanish chamber, yet stretching its influence throughout the world. The character of Philip II is more difficult to grade than it is to understand. Extremely ambitious, industrious, strong-willed, and supplied with a great knowledge of details, all his acts and policies appear to have been in the wrong direction, and to have somehow brought, in proportion as they were carried out, just so much injury to that Church and State for which he so seriously laboured. The Spanish world-power, which had been developed and welded together in an unnatural fashion by a few great personalities, favoured by genealogical accidents, was bound to go to pieces except under the most masterly control. Holland and the northern provinces of Netherlands were the first to free themselves from the hated over-lordship. These form (from the racial standpoint) the district which, of all those under Spanish dominion, seems to have been included the most unnaturally. These provinces comprised almost the same territory as that now known as the Netherlands, so this chapter will follow their special conditions, and have little more concern with the southern provinces which remained long under Spanish and Austrian control.

The wars which resulted in the Dutch Republic were associated with the great religious questions and the horrors of the Inquisition; but the long procrastinated withdrawal of the Spanish soldiers, the burdens of taxation, and appointments of Spaniards to high offices must be counted among the grievances. The decade and a half which precedes this revolution presents a gloomy picture. It was a period of confusion, of persecutions, and uprisings. Thousands of the inhabitants were executed, thousands more left the country, and these were the industrious working classes. Commerce of course received a heavy blow and the wealth of the nation abruptly declined.

It is not easy to fix the exact date for the commencement of 
the Dutch Republic. Its independence was not acknowledged for a long time; but the year 1575 seems to mark its virtual, if not its formal, beginning; especially if we are interested in the relation of William of Orange to the foundation of political autonomy. It was in the summer of 1575 that Holland and Zealand drew up articles of union. By it, William "received supreme command in war and absolute authority in all matters of defence, the control of all money voted by the Estates, the maintenance of the laws as count, in the king's name, the ultimate appointment (after nomination by the Estates) of all judicial officers. These terms accepted, William became, in spite of their nominal recognition of Philip, the true prince of the two provinces." 1 This does not look like a republic, nor do we find such a form of government, except in name, either during the lifetime of William the Silent or under the régime of his sons, Maurice and Frederick Henry. From 1575 to 1578 the unsettled conditions continued in the north, as well as in the south; but after that and until the assassination of William in 1584 the northern provinces enjoyed tranquillity and were again prosperous, even gaining more ground on account of the continued decline which the southern or Spanish provinces were forced to endure.

Thus the period of William the Silent (1575-1584) was progressive even on the strictly material side. The greatness of its significance lies of course in another direction removed from the present inquiry. Great interest is felt in the history of the United Netherlands, not because by heroic action they formed a republic, for this they never did; but for the reason that they fought for freedom, and that here took place a great conception which has engendered a world-wide idea. It was here for the first time that a nation was constructed, founded on ideas of religious toleration. William the Silent was the first to conceive such an idea, and William the Silent must always remain the

${ }^{1}$ Holland (history), Encyclopædia Britannica. 9th Edition. 
pioneer in one of the greatest events of history. William was the soul of the movement. There seems to be no question about this. The delivery from Spanish atrocities and religious persecution could not have been brought about without his aid. They were fighting against tremendous odds. At one time it seemed impossible that the weakened Protestant party could escape annihilation in the revengeful grasp of the mightiest power in the world. But the heart of the great prince never faltered, even in the hours of darkness. William, wrongly called "the Silent," really the most eloquent man of his age, worked on, and by tongue and pen kept alive in others something of that unconquerable fire which was the essence of his own great nature. The ordinary mortal knows temporary exaltations, the crowd once set in motion grows enthusiastic over its own enthusiasm; but a perpetually exalted leader for a forlorn cause is a hard man to find, and men like William of Orange, men who combine, with such unusual strength of character, exceptional intellectual endowments, are so rare that there have been perhaps a hundred such among thousands of millions who were not.

Fortunately for the Dutch and for the liberties of the world, his second son Maurice, on whom the burden of leadership fell, was a descendant worthy of his father. Maurice was extremely precocious, much as his father had been, and although but seventeen and a student at Leyden at the time of his father's death, it was not a year before he was made governor of the United Provinces and stadtholder of Holland-Zealand. For forty years Maurice of Nassau was the military leader of the Dutch nation. They still had Spain to deal with, and Alexander Farnese was no weak general to match. Maurice had to overcome opposition within the ranks of his own people, as well as that directed by the ire of Spain. Historians consider this member of the family of Orange to belong among the greatest military geniuses who have ever lived. If we inquire the reasons for this signal admiration, we discover that, for more than any 
other reason, Maurice of Nassau takes first grade among the world's soldiers because he, like his father, was a pioneer. William founded a nation based on principles of religious toleration. Maurice initiated modern methods of military intrenchment and produced a revolution in the art of war. Like many other innovations in the military art, the changes which Maurice introduced were opposed to the current idea of what constituted heroism in a soldier. The old men ridiculed his plans, the enemy jeered at him as a mere boss of ditch labourers. But before Maurice was twenty-four he had formed the most efficient army in Europe and had made a new epoch. All must needs follow suit and learn his methods or be swept before the irresistible tide. He had formed a veritable school of warfare to which flocked the young nobility of France, England, and Germany.

Maurice was not a statesman. This side of his career was weak, but the Netherlands fortunately had in John of Oldenbarneveldt a man who grandly supplied this deficiency. Maurice became the uncrowned sovereign; Oldenbarneveldt was the States-Gencral itself. These two men brought the Netherlands to a celebrated degree of splendour; or at least we may say with certainty that a glorious epoch for the Dutch people occurred during the leadership (moreover, arbitrary leadership) of two very great men. The quarrel between the two, which finally cost the old statesman his life, stains indelibly the name of Maurice; but, taken as a whole, the impression which the son of the great William leaves on the ages, though not equal in moral grandeur to that of his father, is nevertheless that of a devoted and constant prince. Whether his motives were patriotic or personal (and human motives are very hard to fathom) his own extraordinary life was attended by a brilliant upbuilding of that country which in generosity we must feel that he loved.

The increased international prestige and expanding commerce which signalized this period, continued during the stadtholdership of Frederick Henry, the youngest of the 
children of William the Silent. This prince, less brilliant than either his father or his brother, was nevertheless very highly endowed, and if judged in relation to both war and statesmanship, perhaps better rounded than either. His singular moderation and well-balanced wisdom were of great benefit in reconciling religious factions. It was during his rule that the stadtholdership, already practically hereditary in the house of Orange, became such by written agreement.

The young prince, William II (1647-1650), on whom the mantle fell, was only twenty at the time of his accession. $\mathrm{He}$ was a youth of brilliant gifts, and gave promise of equaling in genius the illustrious members of his family. Like Maurice he was proud, warlike, and impatient of rebuke, and like Frederick Henry and William I his ideas were lofty and comprehensive. Precocious as the others, ambition seemed in him carried to an extreme. William II died aged twentyfour, but in one way history shows the effect of his dominating character. Already the popular voice had grown weak in the presence of such a regnant spirit. The Netherlands had become virtually an arbitrary monarchy. Aside from this, no important changes took place. Commercially and internationally the prestige remained about the same.

When William II died in 1650 there was no heir. Eight days afterwards, his widow, Mary of England, gave birth to a baby boy whose career in life was to be filled with glory, equal to that of any of the family; one who was to save, not only his father's land, but his mother's nation as well from the growing greed of France.

The overreaching methods of the late stadtholder had created much opposition and discontent, so that a reaction set in, and for a time the Dutch Netherlands came under the form of government called "the States," which fairly well represents the democratic idea. Without going into details as to the exact form of government, it is sufficient to say that from 1650 to 1672 there was no royal personal leadership; and there was much independent local control on the part 
of the separate provinces. This did not lead to disaster, or to a period of marked decline. Trade and industry continued as flourishing as before. But one side only of the national welfare suffered, and that was the diplomatic. The subtle work of Louis XIV gradually succeeded in placing the Netherlands in an isolated position, so that she could no longer count on friends or supporters. This was a serious matter in light of the formidable and constantly growing pretensions of France. Clouds began to hang darker and more threatening over the Netherlands. Without a leader her future seemed dubious.

It was young Prince William who saved the day. "In 1572 the storm broke: the English, without a declaration of war, tried unsuccessfully to intercept the Dutch Mediterranean fleet, and France at once set forth to conquer the hated tradesmen of the north. The States were ill-prepared on land, though their fleet was strong and ready; party spirit was exceedingly bitter, and the ruling party, well aware that the Prince of Orange was very popular with the land forces, had utterly neglected their army. On May 28, 1672, Ruyter fought a great naval battle in Southwold Bay (Solebay) against the Duke of York and Marshal d'Estrées: the French held aloof, pleased to see the Dutch and English destroy each other; the English suffered most, but as the Dutch withdrew to their own ports, the others claimed the victory. Meanwhile Louis XIV crossed the Rhine and threatened Amsterdam. The young Prince of Orange alone seemed to rise to the occasion: while others were panicstricken, sending embassies of submission to the haughty monarch, making preparations for a great fight by sea, William with his miserable army did his best, and aroused so strongly the feelings of the people, that Amsterdam, passing from dejection to despair and thence to reckless enthusiasm, rose against the De Witts, and foully murdered both in the streets. They had just before proclaimed William stadtholder of Holland with powers unlimited. And thus Louis 
XIV destroyed the proud republic, though in so doing he had raised up the most formidable enemy he was destined to encounter. His invasion did not prosper; other nations began to take up the Dutch cause; Germans and Spaniards threatened the embarrassed French army in the provinces, so that in 1674 France was on the defensive on every side." 1

After six years' struggle, the peace of Nijmwegen (1678) secured and recognized the independence of the Dutch. This was very advantageous to their commerce, which shows a creditable record during the time of William III (1672-1702). Although the wars depleted the exchequer, general wealth continued to grow, and at the close of the period of William III, the country's credit was good. The Netherlands and England as well were very favourably affected by the revocation of the Edict of Nantes, an individual and personal mistake on the part of the French king. As a result of this act the Protestant countries gained many desirable citizens, mostly of the upper middle class. They brought to their new homes wealth, initiative, and good blood. For this last transformation we cannot credit William III of Orange, but we can debit Louis XIV.

On the other hand, for the early days of William's career, we must give full praise to the man who saved his country from threatened extinction. Reading the descriptions of his exceedingly lofty traits of character and his extraordinary precociousness of mind seems but re-reading the lives of his four predecessors. As a type of the exact historian, Macaulay may not satisfy modern requirements, but inasmuch as opinion of his own hero has not been reversed, let his eloquent words still be quoted in his description of William III :

"Since Octavius the world has seen no such instance of precocious statesmanship. Skilful diplomatists were surprised to hear the weighty observations which at seventeen the prince made on public affairs, and still more surprised to see the lad, in situations in which he might have been ex-

1 G. W. Kitchin. 
pected to betray strong passion, preserve a composure as imperturbable as their own. At eighteen he sat among the fathers of the commonwealth, grave, discreet and judicious as the oldest among them. At twenty-one, in a day of gloom and terror, he was placed at the head of the administration. At twenty-three he was renowned throughout Europe as a soldier and a politician. He had put domestic factions under his feet; he was the soul of a mighty coalition; and he had contended with honour in the field against some of the greatest generals of the age... Courage in the degree which is necessary to carry a soldier through a campaign is possessed, or might, under proper training, be acquired by the majority of men; but courage like that of William is rare indeed. He was proved by every test; by war, by wounds, by painful and depressing maladies, by raging seas, by the imminent and constant risk of assassination, a risk which has shaken very strong nerves, a risk which severely tried even the adamantine fortitude of Cromwell; yet none could even discover what that thing was which the Prince of Orange feared."

However much, or however little, these avowedly extraordinary Princes of Orange may have contributed to the national glory of the Netherlands, it is at least a fact that synchronously with their sway the power of the Dutch reached world-wide proportions; and that immediately on their extinction (through the absence of male heirs), this nation began to decline.

Again the government fell to the States-General (17021747). The forty-five years under this régime do not make as good a showing as the twenty-two earlier years of republican government (1650-1672), which followed William II. It will be remembered that the earlier period was characterized by commercial prosperity, but also by diplomatic and military weakness, so that the international prestige of Holland became insignificant. This second period retrogrades on the commercial side as well as on the political. It heralds the remarkable and well-recognized downfall of the 
Dutch from that eminent position in world affairs which they had occupied during the seventeenth century. The tide turned rather suddenly, and appears to have commenced very shortly after William III's death. The change in method of government in 1747 which eame about because "the provinees had sunk so low that all men began to wish for a dictator," placed the old offices of captain and admiralgeneral of the whole union, and stadtholder of the Seven Provinces in the hands of William IV of Nassau-Dietz. A little later these offices were declared hereditary in both male and female lines. The people seemed to think that in any Prince of Orange, as of old, they ought to find a leader who would save them from the French and restore their prestige.

But William IV was only distantly related to the earlier illustrious branch of Nassau-Orange. There was a possibility of his having been engendered out of the wonderful germ-plasm of the former princes, but it was certainly slight. Roughly speaking and in the light of our present knowledge of heredity we might fairly say that the odds against it were greater than ten to one. ${ }^{1}$ At any rate he was but moderately endowed intellectually, aceording to all commentators. His intentions were good and a number of reforms were instituted, but it does not appear that any important consequences followed either during his own rule or during that of the subsequent regency of Anne, his consort. The period of William IV (1747-1751) is, however, too brief to draw any definite conclusions.

After the death of the stadtholder, the regeney was given to Anne, daughter of George II of England, a woman of a highly ambitious nature and imperious temper, who was not very successful in her headstrong and rather selfish aims. The Seven Years' War injured Dutch commeree, for their navy was no longer in a position to protect this important side of economic life. A shrewd diplomaey might have at least

1 Discussion of the cause of the mediocrity of the branch Nassau-Dietz may be found in "Heredity in Royalty," pp. 94 to 97. 
aided matters somewhat, but no one came forth to guide the fortunes of the little nation, now buffeted about among the more dominant powers. After the unregretted death of Anne in 1757, the States themselves exereised the power of stadtholder until 1766. These years do not reflect glory or indicate improvement. The commercial difficulties became greater than ever before. In 1763, a crisis which hat long been imminent brought down several of the leading mereantile houses of Amsterdam, followed by the usual panic and business stagnation. By degrees things righted themselves, but the Duteh merchants were obliged to content themselves with a business less influential and extended. The rule of William V (1766-1795) saw no changes for the better ; East Indian interests further declined. The diplomatio position continued weak and uncertain. The provinees quarrelled among themselves. The Orange party quarrelled with the people; and the weak, irresolute William I' eommanded no respect. The years 1766 to 1772 again brought failure to many of the old mercantile houses. By 1765 improvement was under way, but the American War of Independence now worked serious injury to the Dutch. The period ended in a revolution; Holland besame virtually a province of France.

Thus the Netherlands take their humiliated exit at the close of the pre-Napoleonic era. The whole eighteenth century had been a series of gradual and constant set-backs, especially national and political, though also commercial and economic. Yet the picture must not be overdrawn. It must not be supposed that there was no wealth and no industry remaining among the descendants of the doughty traders, pioneers of colonial enterprise. Their relative position in the world's trade had declined, other nations had arisen; yet there was nothing of that poverty among the masses, nothing of that picture of utter economic stagnation that characterized Spain and Portugal when their dynastic leadership was withdrawn. There are several other facts indicating a general racial superiority of the people of Hol- 
land, and a certain creditable if not exceptional ability to take care of themselves. The early prosperity of the cities, guilds, and eorporations prior to the fifteenth century shows this, though the same was true in Northern Spain, Northern Portugal, and Northern Italy. The obtainment by the people of the "Great Privilege" under Mary of Burgundy must be accredited to non-royal activity; but this charter remained in foree only for a short time. The progress under insignifieant Philip the Handsome must be counted to the credit of classes other than royal, and of course the modern prosperity of the Netherlands, since the close of the Napoleonic era, is proof that the people now have a very high average ability. On the whole it appears strange that a sturdy country like Holland should show a high correlation between its royalty and its political and economic prosperity, but the two parallel columns compel such a conelusion.

A rapid survey of the broad tendencies from the fifteenth to the nineteenth century shows a strong personal influence of the last two Burgundian princes, followed by a great rise under Charles $\mathrm{V}$ and his able regents, until the bigotry and lack of wistom of Philip II, aided by the evil genius of Alva, and other agents of this busy mischief-maker, turned the tide in a contrary direction. A rise again took place under the five great princes of the house of Orange. This ceased rather suddenly after the death of William III (1702) and did not again commenee within the next hundred years, - during which time royal leadership in Holland was eonspieuously absent.

The showing made by the people of the Netherlands in the direction of autonomous growth is not nearly so good as that of Great Britain during the same historieal epoch. It would seem as if the Dutch race must be lacking in certain qualities which are necessary to make statesmen. Surely their Hall of Fame is deficient in men of this calling, especially noticeable if compared with some other fields of activity, - art, for instance. Cireumstances can hardly explain the defi- 
ciency, since the very forees that might be expected to bring forth political leaders were active in the Netherlands to an exceptional degree. They had an early start in civic selfgovernment. Patriotism might well have been stimulated in the days of the Dutch Republic. The decline during the eighteenth century, with its national disruption, called loudly for great leaders, yet none appeared. On the other hand, a more mediocre frugality and an industry of a widely disseminated sort among the middle classes saved the country from any such cankerous decay as took place in Spain, Portugal, Sicily, or Greece; and the nineteenth century brought forth a flourishing growth in the Netherlands deep-rooted in the strength of the entire population. 


\section{CHAPTER IX}

\section{DENMARK}

IN analyzing the history of Denmark it is best to begin with the reign of Valdemar III (1340-1375). It is often difficult to get information concerning the characteristies of the early kings, and the general history of the nation is too dark and misty prior to the middle of the fourteenth century. A few strong royal figures stand out in the eleventh and twelfth centuries, such as Eric III, Valdemar I, Canute VI, and Valdemar II, and during their sway the country invariably progressed in strength and importance. Between these spasmodic bursts of vigour, weakness and confusion generally prevailed. A more detailed and systematic study of early Danish history (before Valdemar III) would be difficult, would require special research beyond the usual printed volumes, and would not, I should say, be particularly instructive.

Looking over the trend of Danish history from the middle of the fourteenth eentury to the beginning of the nineteenth, the comparatively few reigns which are progressive is a striking fact. From Valdemar III to Frederick VI there are only seven such periods out of twenty. This is a low proportion, and is related to the fact that Denmark happened to have few great sovereigns. At times she held sway outside her own narrow dominions, notably in Scandinavia, but this territorial growth and decline also followed the strength or weakness of the sovereigns.

Valdemar III commenced his reign in 1340 . In the beginning he possessed little more than the very restrieted area of North Jutland. There had been a long period of 
internal weakness: "No monarchy and no revenues, Scania and Halland were in the hands of the Swedes: Funen and Jutland were forcibly held by the counts of Holstein; Zealand and Laland obeyed another chief; and the rest of the isles had each its own ruler who regarded it as his own estate, to be inherited by his children. The anarehy of so many years had caused the laws to be forgotten, and the feeble were everywhere a prey to the strong, and the poor were at war with the rich, the native with the foreigner; and nobody thought of obedience to authority." 1 Yet with this troubled and unpromising beginning, Valdemar, by skilful administration, made Denmark the strongest country in that part of the globe, recovering, consolidating, and extending his dominions, - making his authority everywhere realized. He conferred great blessings on all classes except perhaps the nobility, whose rapaciousness had found a check.

Valdemar was succeeded by Olaf III, but this prince being a minor, the regency was given to Margaret, who afterwards ruled in her own right. This minority was not a weak one. Margaret triumphed over Albert of Sweden, twice bringing to naught his invasion of Denmark. The general administration was so well maintained that on the death of little Olaf in 1387 she was willingly aceorded the full sovereign power. This woman ranks as one of the most intellectual queens in history. The general state of Denmark was distinctly high during the reigns of Valdemar and Margaret. After this, there was no growth worth mentioning for one hundred and twenty years. A particularly sharp decline set in on the death of Margaret in 1412, and lasted through the reign of the weak Eric. Then Christopher III, Christian I, and John successively followed, - kings of a mediocre stamp, and paralleled by conditions likewise without interest. Denmark lost and won territory in the Swedish kingdom and then lost it again. The various long-drawn-out rivalries Bain.

${ }_{1}$ The picture here quoted from the older writer, Dunham, is confirmed by 
led to no advantage. The general march of events was slow and heavy.

An intellectual sovereign appeared in Christian II, but not a really wise and suitable one. His mind was bold, enterprising, and gifted, but his disposition was obstinate, capricious, and excessive. His successes and failures appear as a very natural outcome from a nature so brilliant but so ill-arranged. His was a character to suppress rebellions, and this he did with pitiless severity. The broad ideas of Christian II may be seen in such improvements in the legislature, the commerce, and the condition of the peasantry as make up the favourable side of this period. But the many wars with Sweden appear to have been of no advantage to Denmark. These wasting wars and the excessive cruelties towards clergy and nobles make his reign far from a golden age; but it would seem, everything considered, that more was gained than lost under this brilliant, half-mad king. Christian carried his tyranny too far; his downfall was plotted by nobles and senators alike, and a popular movement finally deposed him in favour of his uncle, Duke Frederick, a man of only ordinary capacity, but cautious and peaceloving.

Denmark was occupied during the reign of Frederick I (1523-1533) by the events of the Reformation. There is no special tendency in regard to political or material affairs.

The interregnum from 1533-1534 was a period of weakness, disruption, and violence. Religious questions had divided the kingdom into two warring parties. Roman Catholics had declared for John, a younger son of Frederick I. Protestants were in favour of the eldest son of Christian. The latter prince carried the day and within a year was well established in royal power as Christian III. His reign was strong, characterized by comparative peace and prosperity, commercial advanee, and judicial improvements.

The reign of Frederick II (1559-1588) was also prosperous, and more notable than that of his predecessor. He was a 
superior king, and also was served by a group of able statesmen. "With the assistance of these men Frederick succeeded in raising his kingdom to a rank of great power, prosperous at home and respected abroad. Never before had Denmark been so well governed, never before had she possessed so many political celebrities nobly emulous for the public good." 1 The public money was managed with great skill, so that the exchequer was enriched without the taxes becoming burdensome. Copenhagen's university was enlarged and more amply endowed, and many colleges and academies were founded in various parts of the kingdom, as well as schools in the towns and villages. Although this reign was followed by a regency of eight years during the minority of Christian IV, the conditions remained prosperous and orderly. "All four men were of great experience and aeknowl.. edged ability, and they exercised their trust in such a manner as to afford much satisfaction to the nation at large. Minorities have generally been seasons of trouble, and if the present was not, the honour might be awarded to the able government of the regents." 2

With Christian IV (1596-1648) we return again to conditions in which the personal influence of the sovereign is omnipotent. Christian IV is the best known king in Danish history. He approaches more closely to genius than any ruler since Margaret, but still is far from being a king of the first rank. The talents and defects of Christian IV are both elearly mirrored in the history of his reign. The early part shows a commercial and internal prosperity which seems a direet result of Christian's aetivities; the last part gives the picture of disastrous wars, the outcome of that same ambition now excessive and unrestrained. A few quotations from Bain and from the older writer, Dunham, will suffice to show how the events of the time followed naturally from the leadership of such a man as Christian IV. "Agile and ath-

1 Bain, "History of Scandinavia," p. 85.

2 Dunham, "History of Denmark," etc., iii, p. 139. 
letic, always extraordinarily energetic and tenacious. . . His writings and sketches testify to a sure hand and a sense of form. Everything decorative attracted him. He was a good linguist. Naturally cheerful and hospitable; he delighted and shone brilliantly in lively society, but he was also passionate and irritable, with strong sensual inclinations, of a plethoric and pleasure loving temperament. Yet he was not without the elements of many noble virtues. $\mathrm{He}$ possessed uncommon courage, a vivid sense of duty, and indefatigable love of every sort of work, and all the inquisitive zeal, all the inventive energy of a born reformer. Want of self-control ruined the fine qualities. He was of the stuff of which great princes are made, yet he never attained greatness ... in the decline of life the bitter fruits of his lack of stability became miserably obvious; and he sank into the grave a weary heart-broken old man." 1

"That Christian, without any great, had many useful, qualities is certain. He encouraged literature and commerce, and patronized literary and scientific men. $\mathrm{He}$ founded cities and fortresses. In all these respects he is deserving of high praise. Active, intrepid in danger, constant in adversity, he would have commanded our approbation had not his object been personal rather than national, had not self been his ruling passion." 2 As for his good works, "the harbours of Copenhagen, Elsinore and other towns were enlarged, a postal system for the whole of Denmark was established in 1624. Many decaying towns were abolished and new ones founded under more promising circumstances. On the national defences he also bestowed much care." 3 Christian IV was evidently a brilliant king, but he made the fatal mistake of attempting to conquer a far greater man, Gustavus Adolphus of Sweden. For this reason the last half of his reign is filled with disasters. To

1 Bain, "History of Scandinavia," p. 150.

2 Dunham, "History of Denmark," etc., iii, p. 160.

3 Bain, "History of Scandinavia," pp. 150-151. 
quote Bain again, "Impatience, ambition, an over-sangine confidence, and above all, jealousy of Sweden induced him to plunge into a war against the combined forces of the Emperor and the League without any guarantee of coöperation from albroad." 'These long wars, instituted to suit the personal ambition of Christian IV, brought lamentable misfortune to Denmark. The king lost the respect of his subjects and of foreign powers as well. The army was defeated, the navy annihilated. Three years before his death a humiliating peace was conchuded at Brömselro. "The peace of Brömsolro was the first of a long series of treaties extending down to our present day, which mark the progressive shrinkige of Danish territory into an irreducible minimum."

In the two raigns which follow, from 1648 to 1699 , the conditions are elifficult to estimate. Her continuous wars with sweden represent the weakest side of the era. These were either quite uscless, or brought territorial advantage not to the Dane but to the swedes, who at this time were under the strong rule of the house of Valsa. The monarehs Frederiek III and Christian V were not distinctive. Christian $V$ was, I should say, somewhat below the average, and Frederick slightly above. The period covered by these two kings is not especially important.

There is still one interesting point here to be noted on account of its hearing on questions of psychology and historical ausation. In the year 1670 , during the reign of Frederick III, there oceurred a sharp change in the form of government ant the constitutional position of the crown. Before that time Denmark was one of the most limited of monarchies. After 1670 until 1848, she was the most absolute in Europe. I have ahready referred in "Heredity in Royalty" (pp. 22.5-226) to this peculiar phenomenon, and have pointed out that this most absolute of monarchies failed to produce, as some might expect, arbitrary or tyrannical rulers. In fact, the kings of Denmark during this 
period were, as Weitemeyer says, "good-natured, upright, and not more than ordinarily gifted." In the earlier history of the country there came forward, as we remember, a rather unusual number of able statesmen originating from the commoners; later they were quite as conspicuous by their absence, - as absent in Denmark as they have ever been in Spain or Portugal.

There is one reign more in Danish history (prior to the Napoleonic period) which should be pointed out as being distinctly prosperous. This covers the years 1699-1730 under Frederiek IV. The acquisition of new territory (Schleswig), and also many inward improvements, financial, industrial, educational, and agricultural, mark the reign. Frederick IV was a rather striking character, extremely ambitious and well above mediocrity, perhaps unprineipled, but withal an amiable, popular, and well-meaning prince. He was one of the very few strong kings in Denmark, and we see the nation well responding.

The next reigns were also prosperous, though not as much so. The country enjoyed two generations of peace, a rare event in any nation. This period was characterized on its best side by conmereial and inclustrial adrance. There was one feature of national life, nevertheless, that bore a cloudy aspect. That was the state of agriculture and the condition of the peasantry. This passed through a severe erisis during the reign of Christian VI, and extended into that of his successor, Frederiek $V$, so that the first of these reigns has a doubtful merit, while the seeonel is a period in which growth somewhat outweighs decline. The personal influence of the sovereigns is quite marked during both reigns. Neither were great men, but both were well-intentioned, and lent their influenee in the right direction. The various treaties, acts, and laws which brought about the commereial and industrial, and later the agricultural, development appear to emanate from the sovereign will. Thus, from the beginning of the eighteenth century a period of about seventy years 
oecurred when Denmark, blessed with good rulers, made ereditable though not distinguished advance.

This suddenly came to an end with the aecession of Christian VII, a poor, degraded, half-witted creature, who had! neither the eapacity nor the desire to rule. The government came naturally into the hands of others. A young German doctor named Struensee, a man of brilliant gifts and insinuating ways, but with a character utterly selfish, brutal, and corrupt, gradually gained the leadership at court. He appears to have had some grand notions of raising the fame of Denmark and became imbued with the idea of changing the whole state of society, but his radieal and revolutionary reforms only led to a condition of chaos. Struensee's ascendency over the imbeeile king, and his notorious relations with Queen Caroline Matilda, together with his general overthrow of the rights of Danish nobles, fomented a conspiracy which ended in the arrest and execution of this extraordinary man, whose theatrical eareer still excites a peculiar interest. This portion of the reign of Christian VII, that is, from 1766 to 1772 , was not progressive; the reforms which fill its history are of doubtful merit, but the last part, on the eontrary, probably had success and value in spite of the weakness and imbeeility of the king. This was practically under the rule of Ove Hoegh-Guldberg, who overeame and reconstructed the evil work of struensee. In his desire to give liberty and importance to the lowest elasses, Struensce had actually crushed the upper classes and overturned valuable tratitional and conservative forees. Besides recovering from this upheaval, Denmark gained steadily in commercial importance, being especially favoured by the American Wrar of Independence.

A new period of sane reforms, especially in agrieulture and tariff legislation, began in 1784, directed towards ameliorating the unfortunate condition of the peasantry. The eighteenth century closed with Danish affairs running along in a fairly prosperous condition. There were three promi- 
nent names connected with this generation, the Crown Prince Frederick, Andreas Bernsdorff, and H. D. Reventlow.

To summarize, we may say, in a broad way, that Denmark was steadily, though rather mildly, progressive from the thirteenth to the nineteenth century. Out of eighteen periods twelve show a well-nigh perfect correlation between the kings and the conditions, and four of the other instances are not far from it. At least five minor or special oceasions are noticeable in which progress emanated from a non-royal source. The number of able, non-royal political leaders, and the number of times a country has progressed under weak kings, ought to be good measures of a nation's superiority. Looked at from this point of view, Denmark would have a position following elosely upon England and Seotland, and at least on a par with Sweden and the Netherlands.

One particularly important generalization from the history of Denmark is that, after the fourteenth century, this eountry had no great kings, and continually remained restricted in territorial and political importance. A comparison of the history of the various nations of modern Europe convinees me that the ehief reason why Denmark remained small was that she did not happen to have kings inherently great: and that if great kings had been born to the house of OIdenburg, Denmark would have expanded, at least for a time, as did Sweden. ${ }^{1}$ From the standpoint of heredity there is no expectation of anything more than mediocrity, or moderate talents in the Danish line of the Oldenburgs. The full pedigrees for each Danish king from 1559 to 1818 contain nothing in the way of genius, and are even curiously devoid of moderately illustrious names. By this I mean that one ean follow up all the ancestral branches (maternal included), until all the great-grandparents of each king have been searched out, and until 132 names have been found, and

1 For arguments which prove that the kings caused the conditions, and not the reverse, see page 280 of this work. 
yet not a single illustrious or eminent name will be encountered. ${ }^{1}$

Both the political history of Denmark and the pedigree of the Danish kings may be likened to several of the small Germanic principalities and duchies. These have drawn their blood-royal from many families in Teutonic Europe, yet they nerer grafted on to their main trunk any of those rare branches of genius that narrowly spread their way through the otherwise monotonous pages of genealogical folios.'

Thus these countries were foredoomed to play minor rôles in the erer-ehanging speetacle of history, yet this did not mean that a more gradual and more widely diffused progress might not take plares without the roval initiative. That it has taken place in most countries of northwestem Europe is well known; hut before one dogmatizes on the eauses of this morement or the direstion of its tendencies, let him first recognize the molermuess of its appearance and the untraditional nature of its atetivitics. Among those European cotates which can lay some clam to an early awakening of such a really national (non-royal) alctivity, Denmark must always have a crelitable place. For this reason its history merits far more attention than has been generally bestowed upon it.

3 Sero "Horedity in Royalty," pp. 225-226.

2 ('bristian II married a sister of the Emperor Charles $V$ from a stock containing much genius; but the subsequent Danish kings were not from this union. 


\section{CHAPTER X}

SWEDEN

The history of Sweden from 1060 to 1250 is one of transition, of long and severe internal religious and territorial conflicts. Gradually out of a rather homogeneous and free peasant population there evolved a class of land-owning nobles and influential families, who more and more got the wealth and political power into their own hands. Historical material for a knowledge of this period is unfortunately very limited. From remote times petty kings were elected by the people, but not until late do we find a considerable number of important rulers with extensive clominions.

One peculiar point is that Sweden slowly evolved her own nobility and did not import them ready made, in the form of Norman or Teutonie emigrants. She did not draw from the tap-roots of the great royal strains of the continent. This may be the reason why Sweden was slow in emerging from small separate kingdoms into a large united government. The extent of the territory and difficulty of communication are usually held to be the causes of this delay towards a wide monarchical sway, but we may advance with equal right this purely biological cause. It is a question whether such geographical facts as extent of territory and natural difficulty of communication have much to do with limiting a regal dominion. Perhaps; but when one thinks of the work of the Asiatic conquerors, of Charlemagne, and the vast sway of the Incas, one is at least entitled to doubts. In fact, all Scandinavia, including Denmark, Norway, and Sweden, was very successfully managed by the great queen, Margaret (1375-1412). 
There are in addition a few other notable figures from the thirteenth to the fifteenth centuries in Sweden (the noblemen Englebrekt and the Stures), but these were not members of royal families, so their study does not properly come within the scope of this work. A hasty inspection indicates that on further study evidence would be found of a rather high general level of character and intelligence on the part of the early swedish people.

For about a hundred years after the time of Margaret, Sweden was more or less under Danish rule and constantly struggling to free herself from the hated yoke. At times she seemed to suceeed, hut the independenee was only temporary. There were no great kings in Denmark during this era, nor were they, with the exception of Eric, distinctly weak. If the Danish kings had been frankly of one type or the other, the question of separate independence for Sweden might have been definitely decided before it actually was.

It turned out to be not so much the weakness of the Danish kings as the enenius of a single Swerlish nobleman, Gustarus Vasa, that gare political independence to his country. This nobleman was raised to the sovereign power in 1523, and from that time monarchical Sweden began as a united and independent nation. From then until the assassination of Gustarus III in 1792, there is a very clear course to swedish history, the ups and downs of which make excellent material for collocting and analyzing after a historiometric method. The annals of this country are unlike Denmark's in two important ways: first, there were many members of the royal family with rare mental gifts, in fact, royal figures of the greatest eminenee; and second, there was a time when Sweden played a very important rôle in European political history, something Denmark never did. The whole period (1525-1792) is easily divided into two subperiods, an age of growth and an age of decline, the beginning of the downward tendency being initiated by the mad 
ambition of Charles XII (1697-1718). In a broad way the two sub-periods outline the story, but there are many counter tendencies which show the personal influence by their sharp reversals in the general state of affairs, as the great leaders come and go.

The man who freed the Swedes and gave them a permanently separate national history was not of royal birth. His family connections were, however, high, being among the leading nobility. When Gustavus Vasa was finally elected king of Sweden, that country had, what is really rare in most monarehies (except the Germanie), a truly native sovereign, - that is, a sovereign whose matemal and paternal ancestry are both grounded in the land over which he rules. Gustavus Vasa must unquestionably be eonsidered a very marked personality. He had all the traits essential to a nation's liberator, - the magnetic enthusiasm, the untiring energy, and the single-minded devotion to a patriotie ideal. Even such faults as a passionate temper and tyrannical behaviour furthered the success of his career.

The most important work which the first Vasa aecomplished appears, however, not to have been the mere delivery of his native land (for this might have been temporary), but rather the internal improvements which oceupied his long reign. Gustavus Vasa was, says Bain, "the greatest constructive statesman of a dyuasty of empire makers. The whole burden of government weighed exelusively on the shoulders of the new king, a young man of seven and twenty. He had to see to everything personally and act on information which he could trust none to collect but himself. Half his time was taken up in travelling from one end of the kingdom to the other, and doing purely clerical work for the want of eompetent assistance. Gustavus was, in very deed, not merely Sweden's king, but Sweden's most overworked servant. His officers did literally nothing without first consulting him, and his care extended to everything, from the building of a smithy to the construction of a fleet, 
from the translation of the Scriptures to the reformation of the Church."

Under his personal direction there was first the establishment of a vastly more orderly and peaceful state of affairs than had existed before. The religious ferments, so universal at that time, were not without their expression in sweden, here taking the form of peasant rising. These called for and received rigorous repression. The next important requirement was to restore an exhausted exehequer, not an rasy task to accomplish in a country so long ill-managed by forrign overlords. It was a fatiguing, uphill task, but towards the rose of the reign, the public walth was well increased, and the taxes were rendered less burdensome. Even more than in these ways, this reign is famous as initiating the commereial and industrial progress of sweden, especially her agricultural and mining derelopments, which from this time began to be very important.

A turn in affairs promptly ensued and precipitated Sweden into a period of elecline as soon as Constarus Vasa died. Eric, who suceecedrel his father, had many of the brilliant mental gifts of the family, but was lacking in practical wistom and common-inse, so that as a sovereign he was utterly incompretent. He had no ability to command the situation. Eric was an orator, poet, musician, and painter, but these gifts wore not neceled. His nature was eruel, suspicious, changeable, and untrustworthy, and very soon he showed the signs of that insanity which attacked a considerable number of the brilliant family of Vasa. Fric XIV was undoubtedly insane at times. During the greater part of the year 1567 he became so deranged that a committee of senators had to be appointed to govern the kingdom. His conduct at best was insupportable either to his own family or to his subjects, and the result was that he was deposed in 1568 by his two brothers, John and Charles, backed by a popular morement. The whole reign of Eric was a dark one. The rebellions and disorder in the court and government 
were attended by an extravagant depletion of the public revenue which brought general discontent and misfortune to the masses.

The reign of John III shows the same general disorder, - popular discontent and extravagance on the part of the crown, and cessation of that material progress in industry and agriculture which made the period of the first Vasa so glorious. John III resembled his brother Eric XIV very closely. His mind was gifted, but chiefly in a theoretical or bookish way. He was an expert linguist and considered very learned, especially in religion. Like Eric, his mind was unstable and his character described as violent, eruel, and headstrong. It is difficult to grade such kings as Eric XIV and John III, and, moreover, the latter has been treated by historians in a partisan spirit. Support of the Catholic reaction has probably prejudiced the Swedes against John, but we can be reasonably sure that neither of these two men belong among the great kings of history or in a class with Gustavus Vasa or Gustarus Adolphus the Great. We also know that Sweden made no important progress during their rule. The reign of Eric was distinctly weak, and considered as a monarch he eannot be classed as more than mediocre. The reign of John, though internally unsatisfactory, contains important territorial conquests on the opposite shores of the Baltic, so that on the whole its totality is doubtful.

During the brief reign of the weak Sigismund, religious disturbances and unsettled conditions continued for a few years accompanied by a series of changes which make a page of reading not by any means peculiar to itself, except in the names of the actors and the details of the events. Time and again we find disorganization and decline under a weak monarch, a personal struggle with some close relative, usually a brother or uncle, and then after a "survival of the fittest" the nation again is seen to emerge from the discord and travel along the upward road. John had ousted Eric, and John was doubtless the more worthy of the two, but 
John was himself unfit, and the same was true of Sigismund, his son and successor.

On the contrary, the Duke Charles was, of all the sons of the first Custavus, the one to inherit not only the genius, but also the rugged practical wisdom, of his father. After five years' struggle, accentuated by religious bitterness, Charles eame off the victor, and Sigismund was formally deposed. The influence of Charles IX was immediately beneficial. Order was again established after thirty years of disruption, and once again the wheels of progress moved in those matters relating so directly to the welfare of the nation as a whole. "He laboured earnestly to improve the judicial system of Sweden, which had as yet no code. He reorganized local administration and the levying of taxes. He favoured commerce and industry with all his power." All writers agree in extolling the success of the brief but important reign of (harles IX. "As a ruler he is the link between his great father and his still greater son. He consolidated the work of (iustavus Visal, the creation of a great Protestant state; he prepared the way for the creation of the Protestant 'empire' of Cinstavus Adolphus. Swedish historians have been excusably inclulgent to the father of their greatest ruler. Indisputably Charles was cruel, ungenerous and vindictive; yet it is impossible not to respect a man who seems, at all hazards, strenuously to have endeavoured to do his duty as he understood it, during that most difficult of periods, a period of religious and political transition, and who, despite his fanaticism, possessed many of the qualities of a wise and courageous statesman. The nobility whom he depressed and persecuted were no doubt justified in regarding him as a tyrant; but the Swedish people frankly trusted and cheerfully obeyed a monarch under whose protection they felt happy and secure, and who loved his country in his own rough way, above all else." 1

This was the commencement of Sweden's famous and

$$
1 \text { Bain, "Scandinavia," p. } 142 .
$$


continuous rise to a position of importance in the world's politics. It began with the first years of the seventeenth century and coincided in point of time with that century almost exactly. The growth was remarkably uniform. There have been but few examples in these tables of European history of any national progress extending a full century without some serious set-backs. Turkey in the fourteenth and again in the fifteenth centuries, and England in the eighteenth, are examples of such long and steady advance. Here in Sweden there were two periods when it is rather difficult to say that the real welfare of the country was enhanced. The outward glory of Charles X's reign (1651-1660) may have cost too great a price, and the burden on the lower classes, in this and the succeeding period, needs to be taken into account; but we can very safely say that there was no time of true retrogression in Sweden during the seventeenth century, or at least until 1697 .

The great names of Charles IX, Gustavus Adolphus, the minister Oxenstjerna, Christina, Charles X, and Charles XI loom large in European history. The impulse from six able rulers falling in sequence ought to be considerable if my thesis be correct; and so it actually was, or at least the six are correlated to a great epoch. Sweden was not only raised to a diplomatic power of the first rank, but her commercial and industrial progress was no less noteworthy. A second inspection brings out the fact that her two greatest gains were made under the leadership of the two, of all the six, who would surely be given the highest rating; namely, Gustavus Adolphus and the minister Oxenstjerna.

The great work of Gustavus Adolphus as a champion of Protestantism is well known, but there are certain other facts in regard to his life which are sometimes overlooked, facts which make it perfectly elear that the man was a born genius, that he was a moulder of circumstances and not their creature. First, we should recall his precocity. He was only eighteen when he ascended the throne, and had already 
at sixteen distinguished himself in war against the Danes as the actual leader of a successful army. Then we should remember the great difficulties with which he was beset from the commencement of his reign. With a small army and an exhausted treasury, Gustavus came upon the throne at a time when his eountry was simultaneously at war with Russia, Poland, and Denmark, and when it seemed as if the Swedish nation would break to pieces in the hands of her united enemies; yet Gustavus not only gave them defeat but actually gained territory at the close of these wars. Afterwards he had Tilly and Wallenstein, both consummate generals, as opponents, and fought against great odds when he united the shattered Protestant party and led it against the great house of Austria.

Another direct proof of the genius of Ciustarus Adolphus is that he introduced entire changes in the methods of warfare. He discovered a more effective system than that in vogue before his time. These changes made possible the rapidity of movement and assault which characterized his victories. At that time the greatest reliance was placed in large, unwieldy masies of cavalry. These (iustavus arranged in small, rapilly moving detachments. At the same time he separated the batalions of infantry at a greater distance from each other, so as to give room for the play of the smaller units. The system of Gustavus was soon adopted by all the European countries and produced a revolution in the art of warfare. Gustavus also instituted reforms in the artillery, using lighter guns. He is said to have first established in modern Europe the true principles of eavalry tactics. ${ }^{1}$ The occupation of warfare did not by any means exlaust the energies of this "Lion of the North" or prevent, as was often the case with other monarchs, needful development of the country internally. The growth of old towns and the foundation of new ones, the increase of educational

${ }^{1}$ For the proof of the great influence which Gustavus Adolphus had on the art of war, sec his life by T. A. Dodge, in "Great Captains" series. 
facilities, of means of transportation, and the general improvement in the administration of justice were all remarkable. Much territory had been added, and Sweden had risen in a period of twenty years to a position of real grandeur among the nations of Europe. Gustavus Adolphus perished on the field of Lützen in 1632 when only thirty-eight years of age. What he might have accomplished had his life been spared.

During the minority of Christina there were twelve years of strength though the nation had no royal leader. At the head of affairs was the eminent Oxenstjerna, who had been valuable to Sweden in the reign of Gustavus Adolphus. The nation continued to play in general a successful rôle in the Thirty Years' War, and the internal conditions remained prosperous. That the good results really depended upon this one man appears evident enough. Thus Bain, in describing the administration of Oxenstjerna during the minority of Christina, says: "During his absence in Germany the policy of the other regents had been vaeillating to the verge of eowardice; but on his return all branches of the administration awoke to new life. . . Oxenstjerna always presided at the frequent meetings of the Rad, his strong hand and watchful eye influeneed every branch of the administration; and anything like slackness, disorder, or venality was impossible during his sway. Many useful reforms too were inaugurated. A committce of experienced jurists was appointed to improve and simplify the course of legal procedure. Trade and industry, especially the fabrication of iron and eopper wire, were vigorously promoted, and flourished exceedingly, so that Sweden held control of the estuaries of all the principal rivers of (iermany. The regular army was reorganized and raised to 40,000 men, an enormous force for a nation with a population of only 1,500,000; while the fleet in 1640 consisted of no fewer than 40 menof-war, and 40 galleys with 1300 guns, besides the skargardsflotta or skerry-flotilla of 150 galleys for special service among the fjords of Sweden and Finland." 
After Christina became of age, she assumed the chief direction of affairs, and the first portion of her reign was full of glory. In 1645 Sweden extorted from Denmark the humiliating peace of Brömsebro. "Henceforth for the next twenty-five years Sweden was justly regarded as the greatest military power in Europe." The peace of Brömsebro was the crowning work and final service of the great Oxenstjerna. In 1648 the peace of Westphalia gave Sweden the duchies of Bremen, Verden, and Western Pomerania. The last portion of this reign was not so successful. The results of Christina's strange individuality are everywhere to be seen. Though she had great wit, learning, and intellectual acumen, her gifts were rather more in nature of brilliancy of accomplishments than judgment and practical ability ; and added to this, her nature was so erratic, headstrong, and passionate, that she was not at all suited to be a successful ruler. Christina began her reign promisingly and encouraged trade, manufactures, industries, and also education, science, and scholarship; but her eccentricities increased and her attachments to unworthy favourites and the general extravagance and recklessness of her conduct brought about a very demoralized state of affairs. Christina herself became tired of ruling and the country tired of having her. The general discontent berame more and more marked, until her abdication, voluntary as it originally was, became absolutely necessary. It is a little difficult to estimate the tendency of Sweden during her ten years' sway. The early part of it was strong and made notable by the treaties of 1645 and 1648, and contained many inward marks of growth. The last part was clearly one of disintegration.

One of the best decisions which Christina made was to have her father's nephew, Charles of Zweibrücken, become her successor. Thus Sweden got another strong king. Under Charles $\mathrm{X}$ order and unity were restored ; the country maintained the high diplomatic prestige which she had won in former reigns. This monarch was a very able general. His 
wars with Denmark were successful, and the new territory acquired was extremely important to the future of Scandinavia. It was then that Sweden acquired Scania, Halland, and Blekinge, which together form the southern tip of the peninsula. The expenses of foreign campaigns under Charles $\mathrm{X}$ were very great, and perhaps the wars were not worth the price, but at least they extended the domain and enhanced the national prestige. This monarch died in his thirty-eighth year. If he had lived, he would probably have benefited the country in many lasting ways, since he seemed to be outgrowing the execssive martial spirit of his youth. Be that as it may, it is very clear that his reign exhibits a course of events entirely in keeping with the reputed traits of character of this ambitious and warlike sovereign.

Charles XI, his son and successor, being only four years old, a regency was appointed, composed of various mediocre characters, and the government sank into an extremely weak state. The finances were very badly managed. Sweden became a mereenary of France, and there was a sudden drop in her political status. Trade and industry, however, remained in a good condition, so that the total effect of the regency was not as harmful as might be expected. The period covered twelve years until Charles XI was considered to have reached his majority in 1672 . He was then but seventeen. His education had been entirely neglected, and at first he took no interest in affairs of state, which continued for the first few years in the same bad condition, and the foreign wars were unsuccessful. These years (1672-1679) cover about the first third of the reign of Charles XI, which portion was weak from every standpoint, but the remaining and more important part was correspondingly strong. By a vigorous and even tyrannical method of reform, which unjustly injured a few, yet benefited the nation as a whole, Charles brought about a restitution of financial strength; and so we find Sweden under this rude but vigorous monarch, again advancing, not only in finances, 
but also in agriculture, commerce, and manufactures, especially eloth and silk. Reforms in the army and navy strengthened the national defenee, making the major portion of the reign of Charles XI a time of peace and prosperity.

Another minority of less than a year's duration must be mentioned, just before the famous reign of Charles XII. The tendeney is not clarly marked, but it appears to be on the whole a successful regency. Cicijer states that the government was weakened by an unmited regeney, that there were disturbances and general discontent; but on the other hand, financial management remained good. Bain, in his history of Charles XII, thus comments upon the regency. It is worth quoting in full, hecause. picturing a considerable number of well-disposed gentlemen acting in a sensible manner for the general welfare of their eountry, it calls to mind one similar occurrence in Denmark, and the comparative rarity of this phenomenon in any country during this age. "The mombers of this regency, if not exactly great statesmen, wore yet at any rate practical hard-headed politicians who had not served under such a master as Charles XI in vain, and during the seren months that they held sway no blunders were made and no national interests were injured; which, eonsidering the diffirulties that eonfronted them at home and abroad, is salying a good deal."

But all the work of construction which sweden made in the last years of Charles XI was shattered to the ground by the career of one of the most extraordinary personalities of modern times, Charles XII, who showed what genius can do when "ambition is madness and valour is ferocity." It is not necessary to follow this monarch in his great war, the audacity of which made all Europe gasp, or to go into details regarding the inner condition of Sweden. It is enough to state that his policy brought disaster to his country, that the finances were exhausted, trade and industry declined, and Sweden "sank to a fourth-rate power."

The Swedish empire was never a homogeneous structure 
or a cohesive collection of similar racial elements with a natural basis for political unity. There were within its boundaries, besides the native population, Finns, Esthonians, Letts, Lapps, Slavs, and Germans. It could only be held together by force of arms. Charles directed this force of arms, and all his active attention, not towards the internal consolidation and management of this unwieldy mass, but spent his nation's resources in a foolhardy attempt to subdue overwhelmingly greater extemal powers. Intoxicated by his brilliant early suceesses, Charles never would listen to reasonable terms of peace, and in the end Sweden lost her lordship of the north. Russia, her ancient enemy, won it. The balance turned in farour of the country that was ruled by the greater man. Peter the Great, the inveterate rival of Charles XII, was as much a developer of Russia internally as he was a eonqueror in war. Charles XII, before the end of his mad career, found himself with exhausted resources, opposed not only by the Great Czar, but also by the neighbouring states, Denmark, Prussia, Hanover, Saxony, and England. Thus isolated and abandoned, Sweden was obliged to submit to such terms as were dictated by her combined opponents. The results of the Great Northern War were complete loss of the extensive provinces on the east of the Baltic, and at the same time, internal ruination and deepest humiliation. All this had been brought upon a land, so shortly before on the pinnacle of pride and power.

After the death of Charles, a drastic change took place in the methods of government so that the position and importance of the crown were entirely altered. It came about in the following manner. It so happened that the legitimate heir, Charles's nephew, the young Charles Frederick, Duke of Holstein, was a weak, irresolute person, and also that no other close relative of the deeensed monareh could command pretensions of leadership. Charles XII had no direct descendants. He had no brothers, and his two sisters were mediocre or mentally deficient. The elder of these was 
childless, the younger had but a one son, the above-named Duke of Holstein. It was natural, that Sweden after her experience under Charles XII, should have longed for some change, but it is improbable that a form of monarchy so very limited in powers could have been foreed upon the crown if it had not been for this aceidental paucity of royal material and absence of heirs in the male line. My belief is that, had there been many direct male heirs, some of them would have had the strength to maintain the old despotism. Chrarles' only surviving sister was elected queen by the Rilisdag, but only on condition that she should surrender the sovereignty to them. This gives us an opportunity to see how well or how ill Sweden could prosper from 1719 to 1771, directed by her own statesmen, and under an extremely democratic form of government. All three of the sovereigns of this era were merely figureheads whose duties consisted of signing such documents as were presented to them. In character and intellect, they were all either mediocre or inferior.

For the first twenty years affairs were very well directed and the work of restoration went on under the firm but cautious control of the chancellor, Count Arrid Bernhard Horn. This period was fairly characterized by peace and prosperity in which commerce, and especially iron, copper, and lumber industries, made creditable advances. This much must be accredited to the Swedish people themselves, or at least to non-royal persons.

That this progress depended more upon the chaneellor, Arvid Horn, than upon general forces, seems likely; since the following thirty-one years which complete the democratic era are quite the opposite in their tendencies. Peace and prosperity did not satisfy the nation. They must have the glories of war. A party of Jingoes, called the Hats, eame into power in 1738 . Horn was compelled to retire, and the new party was not long in bringing on a war with Russia on the most trivial pretext. The state of affairs in Europe and the complications caused by the Austrian suc- 
cession and the death of the Russian Empress Anne led these ambitious politicians to imagine that a war against their old enemy across the Baltic might give them an easy vietory. So far from this turning out as they expected, delays and mismanagements were such that no attack was made until six months after the war had been declared. Then the Russians dealt the first blow, which virtually settled the whole affair; and instead of winning anything, Sweden lost some more territory. Her position was ridiculous. Peace was patehed up, and the greater part of Finland was given back to Sweden on condition that a candidate acceptable to Russia (an insignificant cousin of the Russian Empress) should be elected to the throne once made famous by the Vasas.

During the reign of this mild and weak puppet, Adolphus Frederick (1751-1771), the conditions grew steadily worse. Internal commotions, and general discontent, alternated with a state of lethargy, in which manufactures declined so that only about half as many persons were so employed in 1770 as in 1754. This so-called "Age of Freedom" was not an age of improvement. It was rather an age of license for the nobles. They wheedled all the control away from the fourth estate, bought and sold their political influence, and even betrayed their country into the hands of foreigners. Towards the elose of the reign the corruption in Swedish polities beeame notorious all over Europe. The republican form of government had degenerated into a corrupt oligarchy. Thus after fifty years (that is, during the activities of fully two mature generations) Sweden proved herself unfit for democratic self-government. Under practice and experience, instead of improving, she went backwards and was worse at the end than she was at the start. There is every reason for thinking that these wretched conditions would not have developed, had Sweden been fortunate in having a statesman of the type of Axel Oxenstjerna or Arvid Horn. One sees a considerable number of 
first-rate statesmen before and after this time. There are several instances which show that Sweden had some ability to progress without royal aid, but everything indicates that this has been due to the chance appearance of isolated and exceptional statesmen. The revival of agriculture, industry, and commerce which took place during the yoars 1771-1792 bears out the same view. In this instance the statesman was also the king, Custavus III, the brilliant nephew of Frederick the Great and the last of a long line of illustrious princes.

Out of nineteen periods there are five deviations from strict parallelism between the grades for sovereigns and for conditions. Only two of these are in the form of opposed deviations. The minority of Christina (1632-1644) was very strong though devoid of royal leadership. The great statesman Oxenstjerna was at the head of affairs. In a similar way Arvid Horn appears responsible for the progressive conditions during the first part of the reign of the puppet king, Frederick I. The minority of Charles XI (1660-1672) and the seven months' regency for Charles XII were in some ways successful, and in so far as they were so, the force of inertia seems to be the cause; motion once well started remained in motion. Aside from these comparatively unimportant instances of departure, the kings themselves seem to be the entire story in Sweden. The beginning of the great movement of territorial expansion, the rise and fall, the minor fluctuations within the major wave, the crash from the Great Northern War under the half-mad Charles, and the reconstruction at the close under Gustavus III, - all mirror the remarkable personalities of the monarchs of Sweden, - the eccentricities, the absurdities, and the weaknesses of some, but above all the extraordinary energy and the idealized creative genius of others, who as prime movers in international events, brought a poor and backward country into a nation of the first rank, for a time unrivalled on the continent of Europe. 


\section{CHAPTER XI}

\section{RUSSIA}

Muscovite greatness begins with Ivan III in the latter part of the fifteenth century. Like several modern countries, France, Spain, Portugal, and Prussia, the territories which pass to-day under these names were at first very restrieted in area. For this reason the question of mere land expansion becomes here especially important in relation to national power. Russia was not only consolidated and founded by Ivan III, but also greatly extended under this ruler. The most eursory glance at Russian history makes it noticeable that the great territorial expansions, the most broad and striking facts in Russia's growth have taken place under her four greatest sovereigns, Ivan III, Ivan IV, Peter the Great, and Catherine II. Furthermore, the expansions practically tell the whole story because losses of territory have hardly to be considered.

Pomerania and Finland came in under Elizabeth, Smolensk and Chernigov under Alexis, otherwise no important territorial expansion took place, except under the four abovementioned rulers. This means that there were twenty periods of rule between Ivan III (1462) and the beginning of the nineteenth eentury in which territorial expansion did not take place. Thus a broad initial survey of Russian history shows a high correlation between conditions and rulers. Other important fluctuations of fortune, the questions of relative amount of law and order, condition of the army, treasury, commerce, agriculture, etc., also follow fairly elosely the royal influence, but there are here and there unexpeeted deviations which need to be observed and counted. 
For the first five periods (1462-1584) the whole trend is almost perfectly in accordance with the dynastic facts. Under Ivan the Great the land was almost doubled in extent, and the internal state of the country was also much improved. This continued in a less notable way during the reign of his son Vassili V, who followed the poliey of his father. He was more industrious and brilliant, was exceedingly tenacious of purpose, and succeeded in most of his undertakings.

Five years of minority (1533-1538) which are not "minus" in their tendency followed, but the nine years which close this minority are in every way disastrous. The first portion of the regency was in the hands of an able and resolute queen-mother, Helen Glinska, who kept the disruptive forces in rheck. The last part was devoid of royal control, was charaeterized by intrigues, murders, uprisings, and disorders, in which the Tatars again harried the empire. Russia's future at this time looked very dark.

Under Ivan the Terrible (1547-1584), who with all his marl excesses was an intellectual, energetic, and able statesman, another period of progress occurred. Ivan was no soldier and his suceesses were the result rather of astuteness than generalship. The conquest of Kazan in 1552 was very important, as it opened the whole Volga basin to the Russians. Ivan led his troops in person, but their victory was due more to overwhelming numbers than to merit. In the other direction, towards the Baltic, Ivan IV was not successful. Here he lost territory, though not to an important extent. On the other hand, the home region of the Cossacks was annexed, and also the first eonquest of Siberia must be noted as having taken place during this reign. This was accomplished by the Cossacks themselves, a mere handful of whom under their leader, Yermak, brought the country under their nominal subjection. Yermak then presented his conquest to the Czar, in exchange for which, he received full pardon for certain former offences. Previous to this he had carried his raids in the wrong direction, had been called a 
robber instead of a conqueror, and a price had been put on his head. Ivan had a considerable faculty for getting other people to take the burden of the risks. In this way part of the Crimea of the Tatars was conquered in 1555, and successful raids were made in this territory by the Polish Cossacks while Ivan remained at home. All these conquests appear to be due chiefly to the general weakness of the opponents. The Siberians were too primitive and widely scattered to offer any resistance. Kazan and Astrakhan, though important cities, were comparatively easy of subjugation owing to their location and poor defence. Ivan's merit was that he realized where the weakness lay and appreciated what could and what could not be done, and stopped there. Thus, against the advice of his counsellors, he refused to claim jurisdiction over the entire Crimea, the actual realization of which would have been very doubtful at that time. In all the wiles of statescraft Ivan IV showed himself very astute, and in spite of his fiendishly brutal character, his reign was in many respects beneficial to Russia. He put a stop to anarchical conditions. He strengthened the defence of the empire by building many fortresses. He favoured trade with foreign countries and welcomed foreigners, especially the English and Scotch, who came to Russia in great numbers. It was then that Russia first emerged from her northeastern isolation. Activity in' the arts and much building in Moscow, the capital, give some impression of an advancing civilization, where also for a very brief time a printing-press was set up.

The reign which follows counts one against sovereign rule strictly speaking, for it was in most respects favourable and progressive, yet the Czar Feodor was a roi fainéant, almost an imbecile. The empire was strengthened, the Tatars repulsed, Smolensk fortified, Archangel built, Swedes driven into Narva, and the Siberians still further subjugated. In addition to feats of arms the general commercial relations of the country were broadened, trade passing through new 
channels. The above picture is one to suggest the presence of some single vigorous personality. The real ruler is found in Boris Godunov, a Russian nobleman who later raised himself to the actual throne. This man had married a sister of the Czar, and was, at the death of Feodor, elected his successor. His actual reign (1598-1605) was a continuation of his efforts when merely the power behind the throne; yet it was an unprogressive period, - an instance of circumstances being too powerful. The famine of 1601-1603 is said to have killed a million people. The results were horrible in the extreme. Like so many famines in other countries during the Middle Ages, the inevitable sequences followed, - robberies, murders, pestilence, and even cannibalism. The Czar himself acted nobly and did what he could to alleviate the widespread sufferings, but neither in this, nor in other ways, did he succeed in making himself popular, either with the lower or upper classes. He was an upstart and a tyrant. That his rule was really beneficial to Russia as a whole was not appreciated either by the ignorant masses or the self-sceking nobles. There had always been a story that the younger brother of the late Czar Feodor had been poisoned, and that the parvenu Boris knew something about it.

The real fate of this prince, whose name was Demetrius, is still shrouded in mystery, though it has given rise to much interest and speculation on account of the various impostors who came forward in his guise. The first false Demetrius was a remarkable character. Of this we may be certain, although it does not appear clear just who he was, where he came from, or by whom he was first supported. It was his appearance upon the scene, in October, 160t, which occupied the last six months of Boris's rule in the disturbances of civil warfare. Before the rivalries were settled, Boris suddenly died, leaving a son, Feodor II, who was then but sixteen years of age. This lad ruled but seven weeks before he was put out of the way. Demetrius was crowned 
Czar and gave proofs of personal strength and wisdom, but his reign was brief, as he in turn was treacherously murdered before a year had passed. There was a temporary reëstablishment of a much more peaceful state of affairs. The impostor made himself very popular, both before and after his coronation. In fact the Czaritza Martha, the mother of the real Demetrius, did not dare do otherwise than pretend to identify him and acknowledge him as her own son, so great was the enthusiasm which he had created. All his measures were extremely just and humane. A number of beneficial laws were enacted. There was even in this short time evidence of a more flourishing condition of trade and commerce. "The diligence of the new Tzar was exemplary. He presided over the Council every day, and after listening for hours, with an indulgent smile, to the interminable and unprofitable debates of the boyars, would, in a few moments, unravel and elucidate the most complicated questions. Sometimes he gently reproached the boyars with their ignorance. 'I must send you abroad to learn things,' he would say. He attended to all petitions personally. When his friends the Poles warned him to beware of suspicious characters, he replied, 'There are two ways of ruling subjects, by tormenting or by encouraging them. I prefer the latter way.'" 1 A too great freedom from suspicion was, however, the cause of his untimely death at the hands of his rival Vassili Shuiski. We may well regret that history gives us so little certainty as to the antecedents of this extraordinary usurper, the first Demetrius, and so brief a measurement of his potential possibilities.

His rival obtained the object of his ambitions, and was for a short time theoretically Czar, but his position was always a disputed one. His reign (1606-1610) and the three years following form together the darkest period in Russian history. Vassili Shuiski must be credited with a certain amount of ability, especially in craftiness and intrigue, but his timid-

${ }^{1}$ Bain, "Scandinavia," pp. 173-174. 
ity and weakness forbid him a higher than mediocre rating. Bain gives a fair summary thus: "Vassili's peculiar vices tended to increase the general confusion. He was a nearsighted, nervous, little old man, very shrewd and very stingy, a firm believer in magic, averse from action, and with his ears ever open to spies and detractors. As if his authority was not already sufficiently limited by his character, he proceeded to limit it still further by swearing to punish nobody without the consent of his Council. At the same time he foolishly alienated his own partisans by withholding from them the promised rewards for their services, although they knew him to be rery wealthy. In these circumstances, a fresh crop of pretenders was only a matter of time."

Not only did three pseudo-Demetriuses appear upon the scene as instigators of lawlessness and rebellions, but in the general confusion and disintegration which ensued, all the old enemies of Moseow pounced upon her. Poles, Cossacks, and Tatars all invaded Russian territory, either separately or as allies of each other. The burning, slaughter, and pillage which Russia suffered at this time nearly reduced her to annihilation. Shuiski was defeated, captured, and sent away to Poland. Russia was finally saved from the Poles, and this particular national recovery eame about in a peculiar way. The end of the disintegration and the beginning of a brighter outlook took place under a national religious movement which was initiated by a certain monk, Dionysius. Three other leaders, Prince Pozharski, and Kuzma Minin, a butcher of Novgorod, and one of the gentry named Lyapunov should also be accredited with the work of expelling the Poles, which seems to be much more of a general than personal movement. There is one point, however, on the other side of the question; the king of Poland at this time was the weak Sigismund III. The victories over the Poles make a good count towards progress; but general disorder and lawlessness persisted. The Poles still held many districts, and also, as the national treasury was plun- 
dered, the period known as the interregnum is not more than of middle grade.

Sigismund III of Poland, though the candidate of one party for the throne of Russia, was either too feeble or too unlucky to meet with suceess. After that, the Russians looked about to find some one of their own countrymen on whom to confer the crown. The ehoice fell on a young prince of the noble family of Romanov, Michael by name, who as nearest heir to the old dynasty was elected boyar and received with acclamation by the people. This prince, then only sixteen years of age, owed his election, in part at least, to the great influence of his father, Philarete. The father was raised to a position of joint ruler along with the son. It does not appear that Michael was ever very vigorous. Certainly he was entirely a negative factor at the commencement of his reign. Both father and son were amiable characters, just and generous, and praised for their many virtues. Philarete, the father, is highly lauded for his energy and administrative ability, and the amelioration of Russia during this reign is usually attributed to him. Nothing extraordinary or revolutionary took place, but in comparison to the immediate past, the general tone was deeidedly favourable. There was a diminution of lawlessness and robbery and an improvement in the army. The reign is especially noticeable for an increased activity in trades, crafts, and arts, brought into Russia by Germans, who emigrated there at the instigation of the throne. After the death of Philarete in 1633, Michael earried on the government alone in a ereditable manner. "Michael was not perhaps a great, but he was certainly a good ruler. The universal belief in his honesty and conseientiousness was fully justified, and during his reign the down-trodden and overburdened Russian people looked to the throne alone for relief and justice, nor looked in vain." 1

During the five years' minority of Alexis (1654-1650) the

'Bain, "The First Romanovs," p. 67.

L 
government remained in strong hands. Boris Morosov (non-royal) was in control, and if he erred, it was on the side of too rigid severity. The army was strengthened and improved and there was also an important codification of the laws (16t8), but the value of this legislation is problematical. The chief points which count against this regeney are the numerous revolts and uprisings. Altogether this period is not a long or important one. It was a fairly reputably managed minority. The artual reign of Alexis was one of progress and importance. It paved the way for the greater period of Peter the (ireat. The character of Alexis was similar to that of his father and grandfather. He had an aetive, diligent, and well-balanced mind. The facts most worth noting are that he was extremely kind and affectionate, courtrous in his manners, not at all a tyrant, yet was able to rule sucesesfully over this wild and disorderly people. Save for occasional outbursts of passion (which appear to have been rather examples of righteous indignation) his character was almost saint-like in its mildness.

Alexis died in 1676. His son, Frodor III, followed upon the throne; but as he was only fourteen at that time, and died before he beame twenty-one, it is best to eonsider his reign $(1676-1652)$ is if it were a minority. ${ }^{1}$ There was some intrigue in settling the question of succession, but after that events are singularly farourable considering the state of rule. It is true that Feodor was granted his majority and thus became the titulary ruler in 1679. But as he was then but serenteen ind there is not suffieient evidence that he acted otherwise than under the direction of his favourites, ${ }^{2}$ it is more in keeping with the plan I have attempted to follow not to aceredit the events of $1679-1682$ to him per-

I Feodor was extremely weak physically but not mentally. The characterization "imbecile" in "Horedity in Royalty," pp. 219 and 221 is an error. This Feodor, 7.9, as he did not reach adult years, should not have been included in lists and grades.

2 Waliszewski Le Berceau d'une dynastie, p. 536. 
sonally. The reforms seem to be part of the general infiltration into Russia of western ideas. A more humane penal code was introduced, also better control of the pauper classes, but the most important change concerned the army and consisted in the abolition of the Myestnichestvo or "priority of place." This system of family precedence had been carried to a ridiculous extreme, all ranks both civil and military being determined by an appeal to pedigrees. The measure which led to its abolition is thus described by Bain: "The initiator of this salutary measure was Prince Vassili Vasilevich Golitsuin, sometimes called 'the great Golitsuin,' who now comes prominently forward for the first time. Golitsuin, who belonged to one of the most ancient families in Muscovy, was unusually well educated. He understood German and Greek as well as his mother-tongue, and could express himself fluently in Latin. Born in 1643, he entered the service of Alexis at an early age, and in 1676 was created in boyarin. Sent to the Ukraine to provide for its defenee against the incursions of the Turks and Tatars, he served with distinction during the famous Chigirin campaign, and returned to Moscow with the conviction that the Myestnichestvo was at the root of Muscovy's deplorable military inefficiency. The young Tzar was readily convinced by his arguments, and a special ukaz forthwith removed at one stroke an abuse which has so long appeared unassailable. The razryadnuiya knigi, or records of rank, to which the boyars had been wont to appeal as infallible authorities in all their elaims for preeedence, were at the same time destroyed. Henceforth all appointments to the eivil and military services were to be determined by merit and the will of the Gosudar. The fact that the dying Theodore (Feodor) could so easily remove so deep-lying and far-reaching an abuse is a striking testimony to the steady, if silent, advance of liberal ideas in Muscovite society, even since the death of Alexis. It is often too much taken for granted that Peter created modern 
Russia. The foundations of modern Russia were laid while he was still in the nursery." 1

After the death of Feodor the power was seized by his sister Sophia, a woman of great will and ambition, which she directed towards gaining her own selfish designs. Golitsuin became her paramour, and was openly acknowledged as such. Both were mentally gifted, but they did not sueceed in bringing about prosperity. General circumstances here appear to hold the sway. Golitsuin conducted an expedition of 150,000 Muscovites and Cossacks against the Tatars of the Crimea in 1687-1688, a disistrous undertaking, not because of the superiority of the enemy, but on account of the nature of the country and vast fires which obliged a retreat. Intrigues, plots, and insurrections fill the period.

The figure who next appeared upon the scene was an example, if ever there was one, which proved that circumstances may be the sport of men. In Peter the Great there is a royal personality whose genius is unquestioned. As a little boy he showed no precociousness and was rather backward than otherwise, but by seventeen his real qualities began to appear. It was at this early age that he first took matters into his own hands and became the actual ruler of his vast and turbulent country. His education had been grossly negleeted. Everything that he learned after he was eight years old was self-taught. He was extremely restless, inquisitive, and bent on vast schemes, the precise direction of which he scarcely at first knew. Russia must have a navy and a sea-door for her trade. No pains were spared to effect this gigantic work. Internally the nation needed to be aroused to western eivilization; no opposition could withstand his passion for reforms. The energy, the will, the courage, and above all, the magnetic enthusiasm of Peter the Great alone make him a gigantic figure in history. For purely intellectual qualities Peter does not perhaps 1 "First Romanovs," pp. 193-194. 
belong in the very highest grade of royalty, but there is no doubt but that his mental capacity was great; neither is there any doubt but that his long reign (1689-1725) was one of the greatest eras of progress for Russia. Important increase in territory at the expense of Sweden, especially the acquisition of a seaboard, and founding of St. Petersburg, the betterment of the army, and the creation of a navy, and increase in the trades, commerce, and arts, are the chief features. There is nothing of importance to record on the detracting side.

After the death of the great monarch his widow Catherine became Empress of all Russia, but as she had neither education nor the inclination to govern, the real control of affairs was divided and in the hands of a newly constituted bureau or Supreme Privy Council of eight or ten persons. The government was conducted in a very creditable manner, and, although a brief and unimportant period, must be counted, as far as it goes, in the "plus" direction. There are but two features worth mentioning, first the diplomatic policy, which was peaceful and cautious and sufficiently dignified to command respect, second a lightening of the poll-tax which had weighed heavily on the peasantry. Although Menshikov exercised the ascendency it does not appear that he, or any other one person, is to be accredited with this period of progress.

After the death of Catherine I the Supreme Privy Council acted for three years (1727-1730), but there is little to admire in their conduct, nor are the events of sufficient importance of definiteness to make worth while any comments on this brief period.

The reign of Anne Ivanovna (1730-1740) is more important, but its total value is difficult to estimate. If it be as Bain contends, a progressive period, then it must be accredited to some other cause than the direct influence of the Empress, who at least was not more than mediocre in capacity. For the sake of the argument we may count that 
much against royal influences, but it must be conceded with Morfill that, "the reign cannot be said to have added much lustre to the annals of Russia."

The next two periods occupy the minority of Ivan IV. They are very bricf (1740-1741), devoid of any interest other than court intrigues, and are if anything retrograding in their tendeney. Elizabeth, who reigned from 1741 to 1762 , though uncultivated and immoral, possessed a very keen mind. Russia made great gains during her period. Even if onc is reluetant to eredit much to the individuality of Elizabeth, the same cannot be said of Catherine the Great. The expansion of Russia under this woman's management (1762-1796) is as notable as the decline which followed under Paul (1796-1801).

On the whole Russia shows less identity between "ruler" and "conditions" than might be expected. There are six conflicts against ten parallolisms, but these conflicts do not appear very significant when looked into one by one. The progresive period (1584-1598), though under the titular rule of the weak-minded Feodor I, was really in the hands of Boris Ciodunov, who became an actual sovereign later. The minority of Alexis (1645-1650) was progressive, and its sueces may be aseribed to Boris Moroseov. The period of Feodor III is more diffieult to explain, but lasted only six years. The reign of Catherine I does not mean much, as this was terminated inside of two years (1725 to 1727). The reigns of Anne (1730-1740) and Sophia (1682-1689) on the contrary secm to have been much affected by general causes, one reign favourably and the other unfavourably. Still, the great epochs in Russia's expansion took place under her great sovereigns, and that this was not due to the absolutism of her form of government is proved by comparisons with the more democratie periods in Sweden and the Netherlands, early Spain, and early Portugal. 


\section{CHAPTER XII}

\section{PRUSSIA}

LookED at from the standpoint of eomparative history and in the light of a long range of time, no modern nation has been more uniformly and continuously progressive than Prussia. This progress is notable for its comparative freedom from temporary deelines; but until the middle of the seventeenth eentury it was not more than a dull growth, silent, loeal, and uninteresting; save that to-day this history happens to be the primitive history of what has actually become the leading state in one of the most formidable of the Creat Powers. The aetivity of the Hohenzollerns has been almost without rest. In warfare, in polities, in finance, in government, and in the royal marriage mart as well, the successive princes of this line have usually gained some advantage, - each added something, little though it may have been, to the work of his predecessor. On only two or perhaps three occasions did sloth or decay become manifest. Thirteen reigns show enhaneement of political power or national resources, though some of these, it must be said, do not more than barely turn the scales in the favourable direction.

The history of all that territory now comprised in the kingdom of Prussia would lead one far afield; but inasmuch as the main theme of the present investigation concerns itself with the relations of dynasties to national welfare, it will be suffieient to confine the early portion of this account to that small eircle of modern Prussia, the mark of Brandenburg, the nucleus of the larger State. The name Preussen (Prussia) was originally applied to territory on the shores of the Baltic adjacent to Lithuania, Courland, and Poland. 
This was for a long period under the control of the Teutonic knights, and came by degrees under the sway of the Hohenzollerns, as did also Pomerania, which lies to the west of Preussen and to the north of Brandenburg. These various unions were brought about during the seventeenth and eighteenth centuries. They came slowly into existence, so there is no elearly defined point at which to begin the history of the modern State. Specialists may dispute as to whether this starting-point be taken from the period of the Great Elector, from Frederick I, or Frederick the Great; but these differences do not bring confusion into the present inquiry because this survey shall consider the conditions of only such geographical areas as come under the direct primogeniture line of the present royal family. As soon as these accretions add scope and material to the earlier limits, the new and expanded nation shall be measured as a single entity.

The mark of Brandenburg was, during medi:pral times, an outpest of the empire, - an adrance line of defence for the Tenton against the Skav. In 1415 the Emperor Sigismund rewarded Frederick of Hohenzollern, burgrave of Nuremberg, with the government of the mark, as a return for services already rendered and as a pledge for a loan of 400,000 gulden. Frederick was made Markgraf (margrave) in 1415 and an olector of the empire in 1417 with permanent possession of the mark.

For a century previous to the arrival of the Hohenzollerns, the internal conditions in Brandenburg had been weak and declining. Sines the extinction of the Ascanian line in 1319, the eentral authority had become relaxed, lawlessness and rapine had reduced the country to the lowest state of misery. Robber barons fought with each other, and powerful neighbours took such portions of the territory of Brandenburg as they were able. Thus the dominion which the Hohenzollerns acquired was at first both small in extent (about 11,000 square miles) and very unpromising in future outlook. 
Frederick I of Brandenburg did not wholly succeed in restoring order and affluence, but he did bring about a decided improvement compared with conditions which had persisted for many years. He was much oceupied with the business of the Emperor, the Hussite wars, and affairs outside of Brandenburg; but in spite of manifold distractions, the new guardian of the frontier stemmed the rising tide of lawlessness within the mark, and started the country on its long career of growth and uplift. After many, not always successful, wars with Mecklenburg and Pomerania, he succeeded in uniting again the ukcrmark to Brandenburg, thus considerably extending his jurisdiction to the north. Frederick I was the wonder of his contemporaries. In the opinion of Ranke ${ }^{1}$ he was a genius of the first order. Though this rating seems too high, one may easily agree with Tuttle ${ }^{2}$ that "he was one of the first soldiers and one of the best scholars in Germany."

The improvement continued under Frederick I's son, Frederick II, though the changes were not so notable. The towns of Berlin and Cologne had suffered much during the lawlessness of the previous century. These had gladly welcomed Frederick I as a champion of law and order, but now that the burghers had grown richer they sought more prerogative. Instead of getting it, they were obliged to bow all the lower in submission, and Berlin saw a royal castle within its walls. It would be difficult to say whether this was good for the cities or not, but it is evident that the cities had not shown themselves competent to guide their own fortunes during the extended era of sovereign absence. During Frederick II's reign the neumark was added. Treaties were made with Mecklenburg, Saxony, and Hesse, - treaties advantageous to Brandenburg. The only point worth mentioning not on the favourable side was an increase in the national debt. Frederick II, though not as great as

1 "Preussische Geschichte," I, 104.

2 "History of Prussia," I, 67. 
his father, the founder, had many exceptional qualities, tenacity of purpose being the chief. He was called by his contemporaries "the Iron Man." He was equal to the average of rulers or perhaps superior.

The third of the Hohenzollerns to fill the post of elector became the most famous of the carlier members of the family, that is, the most famous of any from the tenth century to the 'Thirty Years' War. Albert, surnamed Achilles, was perhaps not greater than some of the others of his line who are loss remembered, but his type easily appeals to the imagination. A brilliant eavalier, active, adventurous, lavish in his display, his influence was not entirely for good but his personality was paramount everywhere. Wars and the burdens of wars, enemies humbled, but at a gigantic cost, - such were the natural happenings under the guidance of a ruler like Albert Achilles. There is little more to be said of this reign, except that a strong hand kept fair order, - the first essential of all prosperity. Albert Achilles was too much taken up with the business of the empire, too ambitious and self-secking, to do justies to the land of his home. At all events the mark of Brandenburg did not become weakened.

From 1486 to 1619 a long period elapsed during which the history of the IIohenzollern patrimony offers little to interest the general reader, and all this dull routine eame at a time when the history of many other European countrics is filled with the stirring events of the Renaissance and the Reformation. From 1619 to 1640 mediocrity gave way to disruption, and Brandenburg beeame interesting, but only on account of its disasters, caught as it was in the greater whirlpool of European wars and politics. From 1486 to 1619 , which carries the story as far as the accession of Frederick William, the Creat Elector, no master mind was born to the house of Hohenzollern. As stated at the beginning of the chapter, the efforts of the royal family of Prussia have been almost without rest, and their activities have been 
rewarded with a suceess both rare and remarkable. Even during the period of partial eelipse some very shrewd moves were made, some acts or innovations which looked to the future welfare of the land. But comparatively speaking, taken either in terms of their subsequent control, or measured against the progress made in other parts of Europe, this hundred and fifty ycars spells stagnation for the Prussian State. Seven princes ruled during this era, only two of whom rise a little out of the middle grade. Joachim I and John George were vigorous persons and strong of will. They seem the largest of the seven. The two periods which are frankly the most favourable and progressive oceurred under the rule of these two men.

This group of seven more or less medioere princes with concomitant period of medium conditions was brought to a close with the death of John Sigismund in 1619. Prussia then until 1640 took a very marked drop and then rose again after 1640 until 1685. This makes the reign of George William one of exeeptional interest, coming just before the towering period of the Great Elector and following after a long era of creditable though not remarkable conditions. Again, following the Great Ekector, another sharp downward break oceurred. One genuinely glorious reign is thus placed between two which are acknowledgedly retrogressive, furnishing the student of politico-historical movements a particularly fine opportunity for observation. For this reason I have made a critical study of this group of eharacters, and weighed carefully the various facts, in order to utilize to the fullest extent their important teaching. I have taken this period of history as a subject for analysis and dissection in Chapter XVII, in connection with the larger question of the possibilities of arranging historical eauses in the order of their weight or importance. The detailed diseussion of these well-known fluetuations in Prussian development ean there be seen.

The upturn of 1640 , which saved the State when at the 
point of seeming annihilation, was sudden in its beginnings. It began even in the confusion of the Thirty Years' War, and flowed out of, more than anything else, the young elector's genius for army organization. Afterwards the same master-mind made itself seen in every feature of national life. One European event which especially favoured Prussia was the expulsion of the Huguenots from France. The elector wisely offered the refugees asylum, but the coming of these desirable citizens, and the advantage which they brought to Prussia, may be as much the result of the folly of Louis XIV as the wisdom of Frederick William.

The defect of the reign of the Great Elector lay in its supreme concentration. It was a one-man power. All forces of a popular nature had been strenuously depressed. The estates had ceased to have any importance. Naturally with the death of the supreme head such a system would fall to pieces unless a strong successor followed. The elector has been blamed for carrying the arbitrary policy too far, and from this point of view, and this only, was his régime unprogressive. The reply is, that at this time, or up to this time, no other form of progress was possible save it hinged upon a more or less beneficent despotism. One must always look at history in something of a pragmatic and not in an idealized and Utopian way. Personal liberty is to be desired, but "the rights of man" cannot be counted as a national asset unless there be some assurance that the combined voice of the proletariat will work to the national and social advantage. It might be fairly contended that the Great Elector would have done better had he trained his people to self-government and his subordinates to selfreliance; but how was he to take on the additional task of teacher? We know that he worked a wonderful result and pursued autocratic methods. Is it not justifiable to suppose that his work would have been injured just in proportion as he delegated authority and decision to others beneath himself? We do not know and no one can assert whether 
or not a more liberal policy would have been more advisable.

After his death, affairs did go very much to pieces, and the criticism of his policy finds its chief justification here; but it must be remembered that Frederick I (1688-1713), the son and successor, was by nature a weak man, weaker than the average of rulers by all the indications that one can obtain. If he too, like his grandfather George William, is depreciated and blamed unjustly because of circumstances which no one could be expected to control, then how strange it is that these circumstances become uncontrollable during the years of Frederick I's tenure but were controllable from 1640 to 1688 ; and afterwards from 1713 to 1786 were again controllable.

The troubles during the reign of Frederick I seem to have sprung from corruption among those high in office, from loosening the bonds of discipline among those lower down, and from the lack of a determined and self-reliant policy in dealing with other nations; just the sort of rotting away to be expected from lack of leadership. The public treasure was squandered both by the king and by his corrupt favourites. The army did not deteriorate as much as some other departments, though it also lost rather than gained. Immigration continued to be encouraged. Some few thousand refugees entered Prussia during the reign of Frederick I, but the picture of the rural and agricultural conditions is a dark one. "When he died, desolation reigned everywhere; immense spaces remained uncultivated." 1 The one favourable happening, which proved of great advantage to Prussia, was the acquisition of the full royal title "kingdom" rendering the nation independent of the empire, and placing it on terms of equality with other nations of Europe. Much has been written of the importance of this step, - an advance which did come under a weak ruler. Yet this is never

${ }^{1}$ Lavisse, pp. 233-243. The refugees numbered less than 10,000; also 7000 came to Magdebourg. 
ascribed to other influences than the personal activities of Frederick himself. In fact, the success of Frederick in this line is sometimes cited as a proof of his regal ability. The truth appears to be that the three strongest traits of this ruler's nature were (in the more favourable and the less flattering wording) ambition or vanity ; amiability or supineness; persistence or doggedness. Frederick was determined at all costs to have the crown, and he got it. He toadied to the Emperor and spent a fortune for it. It is profitless to inquire into the motives which lay back of what proved to be a far more valuable acquisition than people supposed at the time.

It so happened that the two suecessors of Frederick I were ordained to add greatly to the national strength, to improve the finances, to expand the army, to inerease the domain, and consequently to vastly enhance Prussia's international prestige. So it happened that the title worked advantageously; but one might ask, did the rank of "kingdom" confer any advantage per se; would it have meant any real political advantage if the men who followed the first king had not been eminently construetive? Judged by analogy with other countries we must answer in the negative. Denmark, Portugal (after 1580), and Poland, though kingdoms, remained innocuous to their rivals. Holland under stadtholders gained a position among the first powers which under her kings she afterwards lost and never recovered. Though rank may count for something in international suceess, it is as yet unproved that any formal status, under which a nation is known, brings prestige and consideration without the actual and practical wherewithal to back up its elaims. Material resources, military strength, actual or potential, combined with ability on the part of the government to control the same, would seem to be the essentials.

It was fortunate for Prussia that the finaneial depletion should cease and that the next king, Frederick William I 
(1713-1740), should develop into a sovereign entirely different from his father. The contrast was complete. The father had amiability and generosity, - qualities which might have stood as virtues had not weakness and prodigality ruined the State. The son was devoid of anything bordering on generosity, - cold, suspicious, cruel, determined to have his own way in everything. His brutal and domineering policy, harsh as it was towards liberality and culture, worked well for the restitution of Prussia's then declining strength. According to Ranke, Frederick William I occupied a place beside Charles XII of Sweden and Peter the Great, equally original in his measures for the organization of his military administrative and rigorously independent state. At the outset of the reign, Frederick William introduced a system of conscription, which, however, had the effect of driving young men out of the country. Finding this to be the result, this measure was suspended at once. The king wisely considered the question of population and introduced foreign colonists. From 12,000 to 15,000 Salzburgers were drawn into Prussia, so that 60,000 miles of deserted land came again under the plough. Fifty-nine royal domains, three hundred and thirty villages, and six cities were repeopled. Training, collecting, and improving the army was a passion with Frederick William, who, in spite of his peppery temper, was a man of peace in international questions. The country enjoyed practically twenty-five years of peace, which was utilized in developing lrome industry, collecting the taxes, saving the money, reforming the judiciary and building up a well-organized despotism. Before the death of the king the revenue of Prussia had been doubled.

Thus Frederick the Great came into a rich inheritance. Yet the favourable circumstances do not in the least explain his great success. The position of the Great Frederick among royalty, reaching as he certainly does the first rank and comparing favourably with any of the picked military heroes of the world, makes it superfluous to more than point 
out this celebrated instance of a country coming into great importance under a great king.

Altogether, the history of the Hohenzollern dominions from 1415 to 1786 gives a correlation as high between conditions and rulers as the history of any European country, even the Spanish and Portuguese monarchies. In Prussia and Brandenburg there are no cases of "plus" ruler associated with "minus" conditions or of "minus" ruler associated with "plus" conditions. 


\section{CHAPTER XIII}

\section{A USTRIA}

The history of that portion of Europe which is now ruled by the house of Hapsburg, and spoken of as the AustroHungarian Empire, or sometimes less eorrectly as the Austrian Empire, contains, within its record of shifting events, much to complicate and render difficult the study and presentation of a unified national development. This country, like France, Spain, Portugal, Prussia, and Russia, has grown by aceretions of territory, but the new additions have been less well amalgamated by the Hapsburgs. Especially is this true in contrast to the three first-mentioned countries, where almost immediately the new lands became French, Spanish, or Portuguese in spirit and charaeter. The great diversity in race, language, religion, habits, and interests among the various elements included within the Austro-Hungarian limits, makes it inconvenient to treat this territory as if it were a single nation. Furthermore, large portions of the empire have been gained and lost from time to time by the Austrian house, gained and lost and finally reineorporated without this fluctuation having any significance at all commensurate with these outward titular changes. At times the same sovereign has ruled over Hungary, Bohemia, and Austria. At other times different members of the Hapsburg family have divided the larger patrimony. At times Hungary, or Bohemia, or minor districts have been ruled by sovereigns of other dynasties, while the extinction of a male line may have reinstated a Hapsburg by inheritance, marriage, or election. For these various reasons it will be simpler to confine this analysis of 
Austrian political and economic welfare, as far as possible, to that geographical area generally known as Austria proper; that is, Upper and Lower Austria together with the ciosely lying southern districts, Styria, Carinthia, Carniola, and the Tyrol. These form a fairly large, well-defined, continuous region, the fortunes of which, both geographically and politically, may be satisfactorily followed, analyzed, and tabulated.

All these possessions came to the Hapsburgs as early as the fourteenth century and have remained under the guidance of their descendants ever since. First and foremost among the progenitors of this august dynasty stands Rudolph the Emperor (1276-1291), whose single-handed effort raised his family from obscurity to consequence, and laid the real foundation for the Austrian growth. Rudolph was chosen Emperor, not on account of his wealth and power, but for the very reason that he lacked the resources which might make him dangerous in the eyes of the electors.

Just as Duke Hugh Capet was raised to the French throne when competition for that position was at its lowest, and no one thought the crown worth the taking, so the patriareh of the Hapsburgs acquired a title that for twenty years had been as valucless as it was high-sounding. Rudolph, like Hugh, took a bankrupt business, reorganized, and rehabilitated it. Although the Holy Roman Empire was never to be again what it was in the Middle Ages, the activities of Rudolph prevented a complete abandonment of the ideas and traditions which had for so long clung about this venerable institution. The period known as the Great Interregnum and the meaningless incumbencies of Richard, Earl of Cornwall, and Alfonso, king of Castile, had reduced the imperial dignity to a shadow. Rudolph directed his attention far more towards internal affairs than to the larger questions of empire. His great merit was that of an administrator, a ruthless suppressor of rebellion and anarchy. In addition to this, his fame has been chiefly enhanced through the successful series of wars which he carried for- 
ward; and all these wars added very materially to the total area of territory which henceforth became incorporated more or less closely under the dominion of Austria proper. Rudolph was a man of gigantic physical proportions, seven feet tall and wiry of muscle, and adamantine of will. $\mathrm{He}$ had a great sense of justice, a practical wisdom, and was greatly beloved by the people, over whom he ruled after the type of the beneficent despot. He is typical of a large class of early sovereigns.

Rudolph died in 1291, and the history of Austria for the next two hundred years is not particularly important. The general growth of Austria during these centuries, if not conspicuous, was nevertheless creditable, and there were not more than two or three periods, brief in duration, when forces of retrogression mastered the slowly moving train of progress. The work of Rudolph was continued under his son Albert (elected Emperor in 1298), who inherited a full share of the vigour, ambition, and ability of his father. Although mixed up in the affairs of the empire, and dominated by efforts to strengthen that disorganized institution, he did not neglect the ever-pressing exigency - the prime need during those ages - the quelling of lawless barons, the punishment of robber knights, and the protection of the weak against the strong; in a word, the maintenance of good governance.

Between Albert I, the Emperor, and Albert II, the Wise, lie twenty-two years of doubtful tendency under the joint rule of the mediocre dukes Frederick and Leopold (elder sons of Albert I), and then again from 1330 to 1359 eame a return to the positive conditions of the earlier reigns. There were territorial gains and judicial improvements of some importance during this period. The two younger sons of Albert I, grandsons of Rudolph the founder, now divided the government. Otto, the youngest, is historically obscure, but Albert seems to have been the one on whom the mantle of the father and grandsire fell. He was called "the Wise," 
able as a soldier and political organizer, learned for the times, and had the same magnanimity and sense of justice that characterized his grandfather in such a high degree. He was altogether a man useful to the best interests of his country and an important person in the long and gradual process of family aggrandizement.

Albert's reign was followed by another progressive period under Rudolph IV, which, though brief in duration, contains many events of importance in the development of the country. Chief among these may be mentioned the aequisition of the Tyrol, an event directly traceable to the personal negotiation of Rudolph IV, a youthful and ambitious sovereign whose picturesque activities leave a lasting impression. Rudolph IV appreeiated that, on the death of the widowed Margaret Maultasch without direct heirs, the Tyrol might revert to the house of Bavaria. Therefore, seizing the psychological moment, he erossed the Alps in the winter of 1363 , paid a visit to Margaret, and by adroit persuasion forestalled the Bavarian elaims and got immediate eontrol, inducing Margaret to renounce the burdens of government in exchange for the eare-free pleasures at the eourt of Vienna. Margaret returned to the Austrian eapital, and the Tyrol has since that time remained among the hereditary possessions of the Hapsburgs.

Rudolph then turned his attention to home affairs, and here also he succeeded in gaining practical results. He increased his income by levying taxes on wine and beer at the same time that regulations were promulgated favourable to other lines of trade and manufaeture, essentially more productive and economic in value. The public revenue was spent in useful directions, and his name is memorable as the builder of the great Cathedral of St. Stephen, and as founder of the University of Vienna, modelled after the University of Paris, to which were ealled distinguished men of learning from various parts of Europe. Rudolph IV came to the throne when only nineteen years of age, and died before he 
was twenty-six. Considering the maturity of his ideas, the soundness of his judgment, and the breadth of his plans, it seems fair to suppose that if Rudolph IV had lived he would have equalled in fame his namesake, the celebrated founder of the dynasty, and perhaps have risen even to the eminence of Frederick the Great or Peter of Russia.

Thirty years of doubtful value (1365-1395) followed his death. The younger brothers, Albert and Leopold, jointly held the government until 1376, when a division was made, Albert keeping Austria and allowing Styria, Carinthia, and the Tyrol to go to Leopold. Both the brothers, though differing in character, belong to the uninteresting, colourless, middle grade.

Albert the Patient, and William "der Freundliche" followed (1395-1406). The same remarks apply to them and to their period. From 1406 to 1411 occurred a distinct relapse into conditions of anarchy. This cannot be attributed to lack of ability on the part of the sovereign power, since one of the two brothers who governed at this time, Ernest, called "Iron," was from all accounts a superior person intellectually, and his appellation referred to his iron will. Ernest and Leopold were appointed joint regents until their nephew Albert should come of age. Both the uncles used every effort to enrich themselves at the general expense, and divided the country in a civil war. Though this weak reign is not connected with weak royal mentality, the behaviour of these two princes gives the clue to the events of the reign. The nation suffered bitterly between the savage rivalry of the uncles and lawless depredations of the barons, who, together with the robber knights and banditti, completed the devastation of the land.

These conditions were reversed under Albert V (14111439). A period of notable progress set in. The credit for all this good work is unhesitatingly given to Albert by all Austrian historians, who unite in praising a prince whom even the Bohemian chronicler admits was "Good for a Ger- 
man." This Albert, "the Magnanimous," as he is called, also rendered an important service to Christian Europe by checking for a time the then rising wave of Mussulman conquest, and defending the frontier kingdom of Hungary against the Turks. Albert was elected Emperor shortly before his death; this elevation and his marriage with Elizabeth, heiress of Hungary and Bohemia, contributed of course, in so far as those events had importance, that much towards increasing the prestige of the Hapsburgs and foscussing attention upon Austria proper.

The people lamented Albert's death and feared for the future. There were two daughters but no clirect male heir. The queen was, however, pregnant, for which reason all three countries, Austria, Hungary, and Bohemia, deforred the question of sovereignty until the expected birth. This proving to be a male, the infant Ladislaus, called in history "the Posthumous," was recognized as heir by the Austrians and Bohemians, and the three nations were in theory united, though actually the entire period was characterized by national and peronal rivalries, intrigues, and internecine wars. Hungary beeame divided on the question of accepting Ladislaus as king. The Austrian party failed to make valid its claim in the kingdom, and Hungarian affairs eame under the control of the afterwarls famous John Hunyady. In the wars against the Turks this great general won long-remembered glory. Though the Christians did not do more than hold their own against the aggressions of Murad II, this in itself was an achievement for which Western Europe had good reason to fecl grateful. Austrian affairs continued to ferment during the reign of Ladislaus "the Posthumous." There was no settled government; the king himself, a weak and umpromising youth, died in 1457 before reaching maturity. The part played by Austria proper in this urgent defence of Christendom was at that time inconspicuous. No great change eame about for fully half a century. The disputes between the brothers, Frederick and Albert, occu- 
pied seven uninteresting years. A more firm and enterprising prince than Frederick might have secured control of the three countries, Austria, Hungary, and Bohemia, for circumstances then seemed propitious. As it was, affairs dragged along without much significance, backward if anything in their movement under the divided supervision of the two brothers.

There was little change under Frederick's own control when from 1463 to 1493 he reigned as Roman Emperor and Archduke of Austria (Frederick III). During this period the Turks made frightful inroads under the great Mahommed II; and to troubles from this quarter were added greater troubles arising nearer home. Matthias Corvinus, king of Hungary, had a grievance to avenge. Before questions were adjusted, the Austrians found themselves no longer masters of their own eapital. The Hungarians were on every side victorious, and it was only through promises of a large money payment that the conquered territory was allowed to retrocede to its former owners. The internal administration of Frederick III was weak, and he was unable successfully to manage either his own territory or the larger affairs of empire. Yet there was one important achievement which enhanced the power and prestige of Austria. Frederick III worked in a slow persistent way, always with an eye to benefiting his own family and private interests. He succeeded in procuring for his only son, Maximilian, the richest heiress in Europe, Mary of Burgundy, daughter of Charles the Bold. She was the last representative of the Burgundian line, and inherited the then enormously rich Low Countries. The bringing about of this marriage, viewed in the light of its subsequent importance, may well be considered a counterbalance to the internal commotions which marked this reign. "Possessed of no genius whatever, but endowed with extraordinary tenacity of purpose, Frederick knew how to wait and also how to outlive all his neighbours and all his enemies. It was thus he was able laboriously to 
unite the whole of the territories of the house of Hapsburg and to secure to his own line the almost unbroken succession to the imperial crown." 1

There is much to be said on both sides of the question if one is to form any estimate of the personal characteristics of the reign of Frederick III, for he belongs in that borderline between true superiority and a larger group of the moderately endowed. Ranke gives a suecinet, summarized judgment worth quoting here in full. "His frugality bordered on avarice, his slowness on inertness, his stubbornness on the most determined selfishness, yet these faults were rescued from vulgarity by high qualities. He had at bottom a sober depth of judgment, a sedate and inflexible honour; the aged prince even when a fugitive imploring suecour, had a personal bearing which never allowed the majesty of the empire to sink." In speaking of the general condition of his reign, Ranke says: "We see that the reign of Frederick III was by no means as insignificant as is commonly believed, his latter years especially, so full of difficulties and reverses, were rich in great results. The house of Hapsburg by the acquisition of Austria and the Netherlands, had acquired a high rank in Europe. The intestine wars of Germany were almost entirely suppressed. The Suabian League gave to the house of Austria a legitimate influence on Germany such as it had not possessed since the time of Albert I.",

If the period and personality of Frederick III are of dubious merit, the same cannot be said for Maximilian I. From this time begins the real greatness of Austria and her entrance into the congress of the powers. This eame through matrimonial alliances more than the fortunes of war. The chief military exploits occurred in foreign lands, and while the desultory and crratic campaigns do not as a whole spell success, they do not appear detrimental to Austria, except as they abstracted large sums of money from that country.

1 Himly, quoted by Leger, "History of Austro-Hungary," p. 153.

\& "History of the Reformation in Germany," pp. 50, 51. 
Maximilian lent important aid towards establishing the Bavarian succession, for which he demanded and received a number of valuable cities and minor districts: Kuffstein, Geroldseck, Nyburg on the Inn, Kirchburg in Suabia, the lordships of Rottenburg, Kitzbuhl, and Weissenhorn, and the landgravate of Alsace. He had already added the counties of Gorica, Mitterburg, and Pusterthal, and afterwards gained some increased jurisdiction on the Adriatic.

Thus from the territorial aspect this reign was progressive. It was also extremely so from the more important standpoint of internal administration. Beneficial reforms took place in all ways, leading to the better establishment of authority and peaceful jurisdiction. Maximilian was an autocrat, a brilliant, persuasive, and acknowledged leader. Such results as there were, both for good or evil, came directly from him. His talent for organization cannot be doubted. It is clearly to be seen in all those reforms associated with military affairs and particularly military technique. He formed the first standing army in Austria. In the improvement of the then primitive art of gun and cannon construction and the manufacture of powder, he was considered one of the leading authorities of his day.

In diplomacy he was too impulsive to succeed well, but in one regard his external poliey led to the most important results. Maximilian had a great deal to do with arranging the marriages of his offspring, and it is well recognized that these marriages enormously raised the power and prestige of the Hapsburgs. Maximilian brought about the marriage of his only son, Philip, with Joanna, heiress of the great Spanish possessions. He arranged the marriages of his grandchildren, Mary and Leopold, each in a way to bring afterwards into his family the kingdoms of Hungary and Bohemia. Although the fortunes of these countries must be considered independently and not as additions to the empire of Austria, the faet that Austria was the home territory naturally raised that country in prestige and ren- 
dered it that eynosure of attention which it held in the eyes of Europe for many years to come. Charles $\mathrm{V}$ succeeded Maximilian, but his reign is not important owing to its brevity. Within two years a settlement of the West Hapsburg possessions gave Charles the Low Countries, Spain, Naples, Sicily, and the Indies, while the younger brother Ferdinand received the Austrian estates including Carinthia, Carniola, and Styria.

Ferdinand I (1521-1564) was prudent, learned, amiable, and well intentioned, and withal a man of wisdom. He was especially noted for his many virtues, and his reign of forty-three years, everything considered, gave satisfaction to the majority of his subjects. In the foreign and domestic wars, suecess about balaneed failure; there were territorial additions to offset territorial losses. The army improved while the finances declined, although an important act was passed to regulate the value of coinage. It was a period full of more than usual difficulties, owing to the confusion of the Reformation. If the reign of Ferdinand I does not stand out as one of importance or glory, it is at least of considerable merit that the disruptive forces of the time were not allowed to take a headlong course, and liberality and moderation earned a fair success. ${ }^{1}$

The reign of Maximilian II (1564-1576) appears to have been more suecessful than his predecessor's, at least if we are attempting to judge purely materialistic conditions. In the great religious questions of the time Maximilian II steered a middle course. In this way he naturally gave satisfaction to neither party, was criticised for his lack of firmness, and as it turned out he only delayed the final settlement. But, if the actual conditions of his reign be alone considered, these

1 I have placed Ferdinand $I$ in the medium grade for mentality. Many would doubtless place him higher, but it must be remembered that there is a constant tendeney to grade every one too high, and the middle grade extends out in both directions, so that it necessarily includes a considerable number of those both above and below the exact average. 
years of recuperative strength, spent in the enjoyment of profound peace, must be accepted as "plus" in their value; and they also call forth at least a passing comment on their signifieance and relation to the great idealistic movement. Here was a time when religious controversies filled all men's minds, when the age of the Reformation was in full swing all over Europe; and yet twelve years of peace and religious quiet are to be found in Austria, reflecting perfeetly the eharacteristies of a sovereign described by all as moderate and peace-loving in his nature.

These conditions did not continue after Maximilian's death in 1576. The whole character of affairs ehanged. The government became weak and corrupt. Religious disputes were not the only source of trouble. To these were added political and economie difficulties, party intrigues, and a peasant's war. Rudolph II was a markedly weak ruler, indolent, self-indulgent, and finally a drunkard, subject to periods of melaneholia. He resigned in 1611, but his brother Matthias (1612-1619), who had intrigued for the throne, though ambitious in spirit, proved no better as a sovereign. His abilities were mediocre, and inereasing years only brought indifference to affairs of State. The reign of Matthias was a period of distinct decline.

Under Ferdinand II (1619-1637) there were a variety of forces at work, the whole presenting a doubtful pieture. It was the period of Tilly and Wallenstein, of the famous events of the earlier portions of the Thirty Years' War. Austria barely held her own in the giant struggle. It was not like the reign of Maria Theresa, important in the development of Austria. Nor ean Ferdinand II be elassed among the great of royalty.

The reign of Ferdinand III (1637-1657) gives equal difficulty to the elassifier of historical events. Internal peace, constitutional progress, and monetary betterment stand against failure in foreign poliey; in addition to which must be noted a continuance of the phenomena - depopulation 
and emigration - which marked the previous reign. Ferdinand III was not himself a remarkable individual.

Under Leopold I (1655-1705) a decided improvement set in. The army was strengthened and gave a good account itself. The peace of Carlowitz closed the Turkish situation greatly to the advantage of Austria. Finances alone showed decline. It cannot be said that Leopold himself was a great sovereign. He was a faithful, hard-working man, remarkable more for his private virtues than his mental abilities. The success of his reign must be aseribed to other sources. Two eminent persons who aided Austria at this time were John Solieski of Poland and Eugene of Savoy.

Joseph I (1705-1711) was a keen and vigorous personality, and stamped his impress on the six years which followed the death of Leopold. The actual management of affairs was much in the hands of the great prince, Eugene of Savoy, but no attempt will be made to separate their respective shares of influence.

Charles VI (1711-1740) is also reflected in precisely the opposite way. The latter part of his period is one of the weakest in Austrian history, both internally and externally. The finances were seriously depleted, the army reached a wretched condition; the wars against the Turks brought disgrace to Austria. Demoralization characterized all affairs of State. Industry and commerce received encouragement, and here a creditable advance was made, but the reign taken by and large must certainly be adjudged disastrous. When the personal traits of Charles VI are considered, one has difficulty in placing this monarch in any ordinary scale for intellertual gradation, from the fact that he was not really lacking in natural eapacity, yet it happened that the kind of things he chose to learn are little valued in a ruler. He was proficient in musie, interested in seience, and a patron of the arts, and at the same time willing enough to work on the more urgent affairs of State. But his mind was incapable of dealing with the large practical question of his time. He 
did not command respect. Though he founded academies and composed an opera, he could not manage his own household. "His intentions were honest and he was anxious to govern with wisdom and justice. These good qualities were counteracted by narrow jealousy, love of adulation, and obstinacy. He succeeded to his dominions in a high state of power and splendour and left them in the lowest degradation and weakness."

Again Austria raised herself, this time under the rule of one of the most famous women of history. When Maria Theresa came upon the throne in 1740 the finances were exhausted, the national credit was gone, agriculture was in a bad state, a general helplessness pervaded everything. It seemed as if Austria was to be devoured by her enemies, Saxony, Bavaria, Prussia, Spain, and Sardinia. Before Maria Theresa's death, forty years later, everything was changed. Financial strength was reëstablished by a rigid economy, coupled with improved taxation; the various portions of the nation were unified, commerce and agriculture improved, the army was reorganized, the navy began to be a force, - - in fact, Austria had become a decisive power in the affairs of Europe. Industrial improvement had taken several forms ; skilled foreign artisans were encouraged to immigrate ; technical schools were established; restrictions concerning trade removed; and spinning and weaving increased considerably.

A few quotations will give a fair view of the importance of the reign of Maria Theresa and of the characteristics of the Empress herself. "On the accession of Maria Theresa," writes Sonnenfels, "the monarchy had neither external influence nor internal vigour, for ability there was no emulation and no encouragement, the state of agriculture was bad, trade miserable, finances badly managed, and credit bad. At her death she left to her successor a kingdom improved by her many reforms and placed in that rank which its size and fertility and the intelligence of its inhabitants ought 
always to enable it to maintain. Maria Theresa had certainly greater claims to the title of "great" than had Catherine of Russia." 1

"A woman distinguished for beauty and for a character far surpassing in vigour that of many of her ancestors." 2

Wraxall gives a few personal touches as follows: "Pleasures in the common acceptation of the term she ean scarcely be said to allow herself. She rises at five in summer, six in winter. . . Parsimonious of her time she usually dines alone and instantly resumes the consideration of public affairs. . . Nourishes many narrow and illiberal prejudices unworthy of a great sovereign.... Those who judge severely incline to condemn her for too great a propensity to munificence. . . Little has age dried up or closed the channels of her liberality. She delights to give, to relieve distress and to extend assistance to merit. Her talents are confessedly good and much above mediocrity. It is not saying enough merely to assert that she possesses more capacity than her father or her grandfather [Leopold], both of whom were princes of very moderate endowments."

Coxe describes her thus: "Easy of aceess to all her subjects, affectionate to her family, kind to her domesties, and unboundedly charitable but without ostentation. She combined private economy with public liberality, dignity with condescension, elevation of soul with humility of spirit, and the virtues of domestic life with the virtues which grace a throne. But it nust not be concealed that she was subjeet to the failings of human nature from which the best characters are not exempt. She readily gave ear to spies and informers, eneouraged tales of private scandal, and indulged in unwarrantable curiosity in prying into the secrets of families. Her death, however, was a general loss to the people, who adored her; her reign is considered as the best and most glorious era of their history, and the halcyon days of Maria Theresa 
are still proverbial throughout the whole extent of the Austrian dominions."

Maria Theresa's son, Joseph II (1780-1790), was a strange character, built of absurd contradictions. Here was a man who wished to bring about democratic equality, yet sought to do so by autocratic coercion. Little educated himself, he was partial to the encouragement of the sciences and the arts. Though his ideals seem prompted by the highest altruism, his methods were tainted by duplicity, selfishness, and vanity. Personally brave, ambitious, and eager for military renown, he was a very poor general and could not even inspire ordinary respect. A mania for reforms of the most sweeping and ill-digested nature characterized his policy. Austro-Hungary was a country unevenly broken up and diversified in races, religions, languages, customs, laws, and institutions. All this was to be obliterated, and a unified and centralized nation was to bring about a speedy and ready-made Utopia. Joseph tried to abolish all distinctions of religion, language, and manners. He divided the Austrian monarchy into thirteen departments to be governed under a uniform system. Paying no heed to the natural forces of conservatism, or the innumerably diverse habits and ideals of different social classes and ethnic groups, such revolutionary reforms shocked and alienated all parties. At first the peasantry, expecting benefits, were on his side, but enforced conscription turned even the lower classes against this new absolutism masking in the guise of philanthropy. This reign occupied a decade, unsuccessful as regards internal administration, and inglorious in war and diplomacy. The personal eccentricities of Joseph II are everywhere to be seen; and to the accidental appearance of this one man must be ascribed the unusual trend of historical events. During the last part of this reign Austria gained a number of victories over the Turks. For these successes the country had to thank the veteran marshal Loudon and the Duke of Coburg; but apart from these victories the con- 
ditions during the reign of Joseph II are clearly enough the handiwork of the monarch himself.

The next sovereign, Leopold II, naturally had a hard task. His rule was brief, lasting only two years, yet time enough elapsed to completely alter the state of affairs which prevailed under Joseph II. The whole poliey of the nation was reversed. The Einheitsstaat theory was abandoned, a return was made to the old forms of government and the Church was again looked to for strength and support. Leopold's reign is so transitory, and the conditions of the whole continent of Europe became so momentous and threatening at that time - owing to the French Revolution - that opinions naturally vary as to the wisdom of Austria's internal policy and diplomatic position. One thing is certain, - that a distinct change was brought about on the death of one sovereign and by the initiative of another, and this change was on the whole for the better. Leopold had shown himself an able administrator during his protracted residence in Tuscany, and it would have been interesting to have seen how well he would have managed the larger affairs of empire had he lived longer. Archdeacon Coxe closes his history of the house of Austria with the following passage: "Leopold is known rather as a grand duke of 'Tuscany, which country he ruled twenty-five years, than as sovereign of the Austrian dominions and Emperor of Germany, because he did not move long cnough in this elevated sphere to fix the public opinion. But if we may judge from effects we cannot withhold great praise from a sovereign, who, within the short space of a single year, relieved the country from foreign war and internal commotion, who baffled a great combination which threatener the independence of his house, and established a throne which at his accession was tottering to its very foundations." Other historians agree that Leopold was a elever, taetful administrator.

Thus Austrian successes have been very much bound up with the personal qualities of the Hapsburgs. For a long 
time their country figured little in European affairs, although of ten the Cæsars of empire sat on the throne of St. Stephen. Except for Rudolph the Founder, no sovereign of high mental rank came in the Austrian line until Maximilian I and Charles $\mathrm{V}$, and these rather celebrated rulers do not match up well with Peter of Russia, Gustavus of Sweden, Frederick "the Only," or the Great Elector. The Emperor Charles V for that matter was but a short time in control of Austrian affairs. These two aside, Maria Theresa is certainly the most intellectual sovereign among the Hapsburgs from the death of Rudolph to the French Revolution, and it is a fact that under Maria Theresa, the one great national movement took place, the one period when very much is to be said concerning Austria's advance. Because of all this, I am inclined to advance the view that Austria might have figured far more powerfully in European history, and the Holy Roman Empire might have remained for a longer time something more than a figment and a fancy, had there happened to be born more great monarchs among the Hapsburgs. 


\section{CHAPTER XIV}

TURKEY

No history makes more remarkable reading than the rise and decay of the Turkish Empire, and none proves more clearly the vast importance of individual leadership. Probably no other dynasty can show such an almost unbroken suecession of great rulers, such single-minded despots as the early descendants of Osman, who for threc centuries and a half ceasclessly conquered and welded out of Hellenistic ruins that vast Mahommedan world power. Nor, on the other hand, can we easily find another country where the fall from eminence is so sudden or where so many weak rulers directly follow one another. Nine vigorous and able leaders are associated with the construction of the Ottoman Empire. Six weak sultans follow these and parallel the rapiel and continuous deeline. Turkey should be compared in this respect with (atstile, Aragon, United Spain, and Portugal, where the political and dynastic changes were similar, being first strong and then weak, but the peninsular monarehies never showed so many repetitions of the same types without contrasts scattered here and there to break the uniformity.

The first seven Sultans were Osman, Orkhan, Murad, Bayezid, Mahommed I, Murad II, and Mahommed II, "the Conqueror." These were, without exeeption, very able personalities, and the father of Osman, who, though not an independent Sultan, did a great deal to pave the way for the great dynasty that was to follow him, might also be included. This nomad adventurer, Ertoghrul by name, was at first but the leader of a small wandering tribe, who, for service rendered to the Seljukian monareh, Ala-ud-din, received grants 
of land in northwestern Asia Minor, which small nucleus became the starting-point of the Turkish Empire. Each of the seven Sultans who followed added considerably to the power of the one who had gone before. The steadiness of the growth from the middle of the thirteenth century to the death of Mahommed II in 1481 is as unusual as is a succession of seven strong rulers. In the course of the uplift an interesting and instructive break occurred between the years 1402 and 1413. For a time weakness and disruption became great. It seemed certain that the Ottoman Empire would fall speedily to pieces. This period, an interregnum, gives us definite dates and undeniable facts. The sharp and brief decline goes a long way towards proving that the progress really depended upon the presence of the strong rulers, and that affairs at any time would have turned in the opposite direction had the central support been withdrawn.

As it happened, Mahommed, who was the fittest of the rival princes, won his right to the succession and brought about a reorganization of the tottering empire. This struggle, giving rise to a true "survival of the fittest," took place in at least two of the ten generations which produced in all nine extraordinary Sultans. If nothing of this sort had occurred, and in each instance the first-born son had reeeived the insignia of sovereignty, we should not expect from the probabilities of heredity that a series of strong types would thus have persisted. ${ }^{1}$ This would have been very improbable for the reason that some of the eldest sons would have inherited the medioere qualities which formed the greater portion of their maternal pedigrees.

1 Even as it is, the continuation of such a strong line seems at first beyond the expectations. No comparable dynasty is to be found among those studied in "Heredity in Royalty." Every persistently strong line is there shown to have been maintained by exceptionally strong maternal blood uniting with that of the male line. The exception, or partial exception, which the early Turkish line presents is not more unexpected than an occasional remarkable sequence in a game of cards. 
There is no evidence that any of the mothers of the Sultans, with the exception of the mother of Orkhan, had distinguished forbears.

The first nine strong Sultans are broken by the interregnum already spoken of between the fourth and fifth, and by the mediocre Bayezid II who is number eight. His reign, from 1481 to 1512 , was not signalized by any adrance against the Christian fronticrs, and is the first period in which the Mahommedan progress is not perfectly evident. Bayezid II was a peacr-loving monarch whose many virtues are highly praised. The conditions of the country were in the main stationary. His son and successor, Selim I, was another instance of the selection of the fittest from the standpoint of governing ability, and during the rule of this noted warrior the Turkish domain became eloubled in extent. Kurdistan, Syria, and Egypt were conquered. Suleiman "the Magnificent" end the list of the nine great Sultans, and under his sway (1520-1566) the Ottoman Empire reached the summit of its glory and power. Hungary, Transylyania, Rhodes, and a large part of Armenia had been conquered. This, together with the territories acquired by the earlier Sultans, made a realm so vast and powerful that Christendom trembled for its very existence. It is not necessary to enumerate the various eities of antiquity that were included in the Ottoman suzerainty, nor to enlarge upon the wealth, splendour, and great building activity which characterized this period. It is enough to point out that Turkey reached its apogee in the middle of the sixteenth century, and that this was coincident with her most progressive single reign, which event took place under the greatest of her great Sultans, Suleiman "the Magnifieent."

It is worth while to take a survey of the various types of moral character exhibited by these remarkable Sultans of the early period from the thirteenth to the sixteenth century. Fierce, cold-blooded, cruel, and unjust might be the type expected, if the age in which men live has anything of that 
influence which so many claim for it; but, as a matter of fact, only three of the first ten Sultans conform to this picture of a "terrible Turk" and fulfil this preconception. Bayezid "the Thunderbolt" was such a character, and so was the cruel and faithless Mahommed II and bloodthirsty Selim I; but examples of the opposite type are more numerous, - the upright Orkhan, who was not in the least cruel, the just and magnanimous Mahommed I, the humane and equally just Murad II, the mild and virtuous Bayezid II, and the three others, namely; Othman I, Murad I, and Suleiman I, were essentially well meaning, with an excellent sense of justice and possessed many virtues. They were not wantonly cruel, but it cannot be denied that various isolated crimes, especially murders, must be charged against these three rulers. These high-handed acts of lawlessness which would scem impossible in a molern western civilization were carried out in a cold-blooded way against the members of the Sultan's ministry or of his own family. They seem to have been actuated usually by fear of rivalry, and were generally looked upon as necessities of State policy. Indeed it was a settled custom that the Sultan, upon coming to the throne, should either cause his brothers to be killed or kept in close confinement. Here we have, it seems to me, an example of what "the spirit of the times" may do, and what it may not do. It could not make the first ten Sultans conform to any definite type of character; it could not eliminate the extravagance of the contrasts, - three cruel and tyrannical, but four mild and humane. But as far as the other three are concerned it would seem that surrounding circumstances had at least determined or allowed the acts of violence.

The Ottoman Empire, formed under great organizers and military leaders, became a power so extensive and an organization so perfect, that even eight years under the besotten and imbecile son of the great Suleiman could not more than barely turn the balance in the opposite direction. Under the weak Sultan Selim II the inevitable personal intrigues 
among those high in the circles of the court worked their fatal consequences and the defeat of the Turks at Lepanto gave the first serious setback; but for the most part the generals and statesmen trained under Suleiman continued to act as before, and even some new territory (Cyprus and Tunis) was added to the empire. The presence of the grand vizier Sokolli probably had much to do with the continuity. He was a very able man and had been sulciman's chief lieutenant, and excreised great ascendancy over most of the affairs of State during the reign of Selim II. "When Sokolli's authority was weakened and broken by the corrupt influence of favourites and women at the court of selim's successor, Murad III, the shock of falling empire was folt throughout the Ottoman world; spreading from court to capitol, from the appitol to the provinees, and at last becoming sensible even to foreign powers." I Murad III (1574-1595), under whom the grat decline first began, was the socond in the continuous chain of six woak sultans; after this came one strong ruler, then one wrak, and then one strong, and then seven weak. A line of as many as six or seren weak rulers in minterrupted suedescion is extremely rare in European history. This is the only instance I recall of such protracted misfortune. Even in early seotland, where there were so many minorities, and where feehle rulers were so numerous, there were never six in rontinuity. The line of wak sultans carries us from 1566 to 1623 . The pieture of one reign is characteristic of all. Insubordination, revolts in the army, defcats in battle, loss of territory and of prestige, internal misery, intrigues, disordors, murclers, and robberies, - these are the headings of page and paragraph.

Then from 1623 to 1640 a sharp right about face occurred. The army was reformed. Order and discipline were established. The revonues were much more honestly administered. Bagdad was retaken from the Persians, and Turkey began to regain her former position. Murad IV, who reigned

$$
\text { 1"Creasy," p. } 224 .
$$


during these years, was, in spite of his cruelty and vices, a particularly vigorous, decisive, and courageous character. Under his weak brother, Ibrahim, the downward movement recommenced and runs into the minority of Mahommed IV; and then sharply the years 1656 to 1676 mark a contrasting picture. The whole merits some detailed deseription. First let it be fully realized how strongly these twenty progressive years stand out in the chronology of declining Turkey. These dates correspond exactly to the beginning and end of the rule of the two famous grand viziers, the elder and younger Kuprili. They were father and son, both men of high ability and lofty aims. A few lines from the historian Creasy will give a good idea of the importance which is attached to the careers of these two statesmen.

"A stern correction of abuses was required; and $\mathrm{Ku}$ prili [the elder] applied it, not indeed with the ostentatious eruelty of Sultan Amurath (Murad IV), but with the same searching and unsparing severity which had marked that monareh's rule. No delinqueney, past or present, no preparation for plot or mutiny escaped the vizier's vigilance. He planted his spies in every provinee and town and secured the ageney of trusty and uncuestioning executioners of his commands. The impress of a resolute will was felt throughout the empire; and men obeyed without hesitation the man, whom they perceived never to hesitate himself, never to neglect or abandon those who served him, and never to forgive those who thwarted or disobeyed him. The revolts which had raged in Transylvania and Asia Minor were quelled, the naval strength of the empire was revived; the Dardanelles were fortified; the Ottoman power beyond the Black Sea was strengthened by the erection of castles on the Dnieper and Don, and, though the war in Candia still lingered, the istands of Lemnos and Tenedos were recovered from the Venctians. His own authority in the empire was unshaken until the last hour of his life; and he obtained for his still more celebrated son, Alhmed Kuprili, the succession to the 
grand vizierate. Ahmed Kuprili was the real ruler of Turkey from 1661 to his death in 1676, and he is justly eulogized both by Ottoman and Christian historians as the greatest statesman of his country. The value of such a minister as Alimed Kuprili to Turkey was soon proved by the rapid deterioration in her fortunes under his successor in the vizierate, Kara Mustafa or Black Mustafa: a man whose character was in every respect the opposite of Kuprili's."

All this offers excellent proof that the broad decline in the Ottoman Empire, which began with the death of Suleiman, "the Magnificent," in the middle of the sixteenth century, was not due to essentially external or general causes. Here a hunded years after that time two periods of distinet reorganization and progress were possible under the Kuprili and Murad IV. The peculiar fact that a period of decline under Ibrahim comes in between the two should be e. pecially noticed. This makes it unlikely that any gencral forces of a favourable nature were at work at about that time, between 1623 and 1676 , to favour Murad IV and the Kuprili.

This brief analysis of the empire of the Turks is brought to a close by a second succession of weak sovereigns, covering little more than a century, showing nothing of interest beyond a rapid decline, and then a low dead level of apathy, during which the "Sick Man of the East" may be said to have temporarily convaleseed on only two oceasions. The early part of the reign of Mustafa II shows a slight recovery. The Sultan himself led his troops against the Austrians, gaining an important victory, and then applied every effort towards improving the internal condition of the country. Mueh was accomplished during that year, but after Prince Eugene of Savoy appeared upon the field of battle, "the Creseent soon went down before him." This sudden spurt terminated abruptly; and very shortly after this the character of the Sultan took on a complete change. He became as indifferent and dissolute as he was formerly vigorous 
and decisive. Everything went to pieces. Even the temporary organization of forces under the last of the great Kuprili amounted to nothing. The famous peace of Carlowitz in 1699 proclaimed the final exodus of Turkey from the ranks of the directly aggressive European powers. Since then her importance became diplomatic, not for what she herself might do, but for what other ambitious powers might do with her. It is true that the Ottomans were occasionally successful in warfare, and there is a broad general improvement during the first half of the eighteenth century, which is the only movement of its nature in Turkish history that is not associated with great names and personal leadership. This recovery in the strength of the Porte appears to be due to general Europcan conditions, and to weakness and mismanagement on the part of her rivals. The success of the Turks against Peter the Great at the Pruth in 1711 was probably due to the ill-advised campaign of the Russians who had an army far too small to cope with the numerically powerful Ottomans. The great activities of Sweden under Charles XII also indirectly favoured the Turks. The reign of the weak Mahmud I (1730-1754), which followed this period, was even more a time of triumph for the Turks. It would appear that the support of France and especially the work of Villeneuve and Bonneval had much to do with the consideration shown Turkey in the treaty of Belgrade in 1739. Probably the mismanagement of the Austrians had contributed much. It was not the good fortune of the Sublime Porte to long enjoy an easy couch for insouciance, nor did her tormentors long remain in abeyance. The reign of Othman III passed briefly (1754-1757) without any important significance. Four years of prosperity followed, until 1761, under the guidance of the able statesman Raghib. The remaining years of the rule of the mediocre Mustafa III were filled with disasters. This is equally true of the period of the weak Abd-ul-Hamid, so that the twenty-nine years which bring Turkish history to 1789 are years of disorder, 
defeat, and further loss of territory. Here Russia and Austria became triumphant.

Thus the whole history of Turkey from the thirteenth to the nineteenth century, in its growth and derline, shows ten progressions under strong, and ten declines under weak Sultans. Her great and able viziers, especially the Kuprili family, who formed an inner dynasty behind the throne, did much from time to time, but the areas of progress under the grand viziers were not as important or as numerous as those under the sultans. There are four oceasions during which Turkey adraneed under weak monarehs but strorg viziers. There are ten periods when the progress is directly traceable to the sultans themselves. There is but one period, that hetween 1730 and 1754 , not almost perfectly paralleled by the mental capacity of individual leaders. 


\section{CHAPTER XV}

\section{SCOTLAND}

The early history of Scotland is one of great confusion. Even down to the eighteenth century the annals are filled with party strife, border raids, and petty warfare. Frequent changes in the government make the national conditions of progress and decline not as definitely marked as in most countries. Scotland was a very backward nation, and continued until recent times in a condition of lawlessness, rudeness, and ignorance, long after some parts of the continent had reached a high degree of culture and splendour.

I shall not attempt to trace the history of Scotland prior to 1306 , the accession of Robert Bruce. This national hero, who stands in comparison with his successors somewhat isolated in grandeur, did a great deal for his country besides freeing it from the overlordship of England. He, to a considerable extent, consolidated the rival elements, and the legal aspects of his administration should not be overlooked. At the parliament at Scone in 1318 "many wise laws were passed touching the administration of justice, the organization and mustering of the army, and freedom of the Church." It is true that the long wars of Bruce's reign had their dark side, especially in their effect on the condition of the poorer classes, but the general tenor of the period was doubtless successful. He was not only beloved in his own day but his memory was long after venerated, - a notable career and an excellent instance of personal influence.

The next administrator was the Earl of Moray, who acted as regent from 1329 to 1332 . Here one notes, as elsewhere, that minorities themselves are not to blame when conditions 
are found to be weak. Macaulay cites Scotland to prove that minorities are harmful, but the fault lies not in the form of government, but in the absence of a strong hand. ${ }^{1}$ The Earl of Moray was a just, vigorous, and wise man. His administration was eminently successful, The next regent, Donald, Earl of Mar, a nephew of Robert Bruce, held the reins but a very short time, for he soon led the nation to disaster, and was defeated and slain in 1333. Mar is described as having no qualifications for the office. The remaining years of the minority of David II were equally unsuccessful. Disaster, defeats, and confusion fill the period. Four different persons occupied the office of regent, but no vigorous characters can be found. David II himself proved a weak king. $\mathrm{He}$ is summarized as incapable, headstrong, extravagant, passionate, and addicted to pleasures. As for national affairs, the Scots were defeated at Neville's Cross, the English overran the southern part of Scotland, and the king was taken a prisoner to England, being released only after his countrymen had paid a large ransom. The internal state of the nation was deplorable. Turbulent nobles impoverished the commoners, and the commoners flew at each others' throats. Notwithstanding this, some parliamentary advance can be discovered. In attaining parliamentary growth under a weak king Scotland resembled England. She did the same, it should be noticed, under a later weak king, Robert III. These facts should be contrasted with the stunted growth of the parliaments in Castile, Aragon, and Portugal.

Under Robert II (1371-1380), who founded the house of Stuart, there was some improvement. The Scots were victorious at Otterbourne, which did much to remove the dread of England, and gave a greater national prestige; but still the internal affairs of the northern kingdom remained very unsatisfactory. Continued warfare exhausted the country and social and material progress was much retarded. Robert 
II was not a great, though he was a naturally clever, person. He was lazy, and at that time of life already in declining health. The portrait of the first of the Stuarts is drawn by Froissart as a man, "not valiant, with red bleared eyes, who would rather lie still than ride." His son Robert III was even more indolent and was furthermore deficient in natural parts. He held no power over the nobles or over his jealous and turbulent brothers; and the whole picture of Scotland is one of dire confusion, of English raids, and private warfare. As before noted, in spite of this lack of leadership, parliament met and enacted new laws which somewhat bettered the condition of the lower classes.

In the next period occurs the first able and vigorous leader since the Earl of Mar. This man was Robert, Duke of Albany, a younger son of Robert II. Although no sudden complete and wonderful change took place, there is no question but the sixteen years accredited to him count for decided improvement, - first, the complete subjection of the malcontents, second, the important victory of Harlaw (though under the leadership of another of the Stuarts), and third, the foundation of the earliest university in Scotland, St. Andrews. A quotation from the "Dictionary of National Biography" will give a fair view of Albany and also his influence.

"Of his strong personality and great ability, his remarkable ascendancy over the turbulent nobility is sufficient proof. Chroniclers of the period, while they bear witness to his imposing presence, are almost equally unanimous in extolling his affability, temperance, justice, fortitude, and wisdom." Albany died in 1419, and at once three years of weakness, disruption, and retrogression set in under his son, the indolent and incompetent Murdoch. There was soon no doubt as to the incompetence and corruption of his rule, and "the majority of the nation became more than ever anxious for the return of the king."

This refers to King James I, who since boyhood had been 
held captive in England. It is worth noting that a sudden break occurs here between two strong periods. The reign of James I (142t-1437) proved the most uniformly and entirely progressive in all early Scottish history, - the foundation of the statute law, the suppression of private warfare, regular and frequent meetings of the parliament, a general survey of the kingdom for the purpose of valuation, a regulation of weights and measures and coinage, in fact the beginnings of something worthy of the name of civilization, and a progress that might have endured and developed, had Scotland continued to have rulers like James I. James I was, without doubt, the greatest Scottish king since Bruce, and the general excellence and variety of his gifts and his noble moral character make him compare favourably with royalty of the first grade. He was strong, brave, and hardy, just and liberai, and besides being an able legislator, administrator, and organizer, was one of the most accomplished princes of his time. Indeed, for Scotland he was far ahead of his time. The policy of James $I$ in reducing the power of the baronage as against the clergy and the commoners, though generally so welcome to the mass of the people, could naturally not appeal to the barons themselves. A conspiracy took root among some of the latter class, which ended in the murder of this excellent king in 1436, when he was only forty-three years of age.

Scotland enjoyed no more progress for a number of years, and, moreover, the peaceful and settled state of affairs terminated abruptly. The minority of James II was not controlled so much by weak hands, as it was by overgrasping ones. Confusion and the old game of party warfare filled the period. The conditions here appear to be directly due to the outward form of government, not to lack of ability in the regency.

With the maturity of the king came a gradual improvement. It took some time to suppress the civil wars, for the party of the Douglases was very strong. The defeat at 
Arkinholm in 1454 placed everything to the advantage of the Stuarts, and Douglas's subsequent flight over the border left James free to restore the much-needed order within his own domain. This he did with astonishing success. James II had all the energy of his father, and was even more successful in suppressing the lawless barons, and in giving to Scotland some little hope of that stability of government which is the first necessity for national advance. Border raids had become chronic, and these did not wholly cease; yet, comparatively speaking, the brief reign of James II, was an advantage to Seotland. There was further progress in legislation, especially in measures looking towards agricultural improvement, finance, and the rights of the lower classes. Unfortunate accidents took off the good rulers of Scotland before they had time to develop their best selves, or demonstrate beneficent influences. James II was killed at the siege of Roxburgh, aged thirty, by the bursting of a cannon. Artillery was new in Scotland, and James, whose interest was great, was watching it within too close a range.

Another minority followed, which brings added argument that such an arrangement of the government is not necessarily a disadvantage. The man at the head of affairs was Kennedy, Bishop of St. Andrews, a grandson of Robert III. He has been very highly praised for wisdom and excellence of moral character. His death, in 1466, after a six years' regency, was lamented as a public calamity. The peaceful and moderate rule had given the law-abiding class a hope for a permanently well-ordered future, but this was not to be. As soon as Kennedy died the troubles began again. From that date, all through the remainder of the minority of James III, and during his own feeble rule, nothing but plots and counterplots, weakness and criminality, fill the dreary pages of the history of the period.

James IV, differing from his father, was at least brave and energetic, and with his accession there came a decided improvement over the conditions which existed under his 
father. The capacity of James IV was not equal to his ambition, and his deficiencies were very clearly marked in the results of his sovereignty. Bold and imaginative, his somewhat quixotic designs served a very good purpose up to a certain point, but carried with them a chain of evils. James IV was brave and sufficiently firm to quell the nobles, energetic enough to lay the foundations for a considerable naval power, skilful in diplomacy, and we see Scotland entering the field of European politics; but the results of his personal weaknesses are no less noticeable. James IV's extravagance, his rashness, his poor generalship are seen, first, in the impoverishment of the exchequer, and second, in the disastrous defoat at Flodden Field, the death roll of which surpasses any other battle in Scottish history.

Again a long minority and again unsettled conditions followed the reign of James IV. More than a passing word, too, must be given the duke of Albany, who was a cousin of the king and held the regency during part of this troubled period. It is difficult to get the truth about this Albany; he seems an enigmatical character, about whom differences of opinion can casily exist. Perhaps the best view is that Albany was a naturally able man, and that the first part of his administration was successful, the latter part unsuccessful. His task of restoring order among the nobles was exceedingly difficult, and he lacked the ideals and the moral courage necessary for such a discouraging task. He sought repeatedly in France respite from his burdens, and a rule over Scotland in the sixteenth century without constant, vigorous, personal circumspection was out of the question.

With James V (1528-1542) the nation's fortunes changed. He was not a very great king, but he was active and vigorous, well inclined towards the lower classes, while at the same time he kept the refractory nobles in check. With the exception of the Scotch defeat at Solway this reign may be called prosperous. There is little of interest in the four periods which follow, at least as concerns advance or 
decline in the economic and strictly material conditions of the country. A weak regency under a weak regent, the Earl of Arran, is followed by a regency under a very able woman, Mary of Lorraine. The events of the Reformation occupy nearly the entire period, and it is much to the credit of the queen-regent that the years of her rule (1554-1560) were not a time of distinct retrogression. The reign of Mary, Queen of Scots, interesting as it is from so many points of view, has very little bearing on the present inquiry because like that of the regent which precedes it, the material or economic affairs are so confused that it is impossible to say which way the scales turn. All the interest is converged around religious questions. Perhaps it would be only fair to call this reign one of decline owing to the civil conflicts which form its most eonspicuous features.

In the minority of James VI (1570-1587) there are five distinct sub-periods. At two points we notice superior or "plus" conditions. The first of these is clearly due to the energy and firmness of Murray. The second was under Earl Morton, not a member of the royal family. This man was entirely unserupulous and merciless, but "he put the country in order and gave it peace." The other three sub-periods of the regency were under weak control and are characterized by the usual turmoil and disorders.

James VI of England was a shrewd, learned, and pedantie person. He was both strong and weak, both wise and foolish, but is not rightfully described as the "wisest fool in Christendom." James was not very wise. Wisdom in the sense of good judgment was what he lacked. He certainly was no fool, for no fool could ever have left such an interesting impression of himself upon historieal memory. However we may view the curious make-up of James's nature, it has no special importance here, for the reason that the course of Seotland's progress is, at this time, too ill-defined, too difficult to measure. The king's influence appeared in many small matters, but in a larger way it is enough to say 
that this is a mediocre, or weak, period under a mediocre, or weak, king. Nor do the eivil wars of Charles I's time furnish that sort of historical reading which makes it easy to affirm whether the general national tendency is upward or downward. In spite of all the evils of internecine wars, perhaps it is true that "viewed from a political and moral standpoint the Covenanting struggle was a very important factor in Scottish civilization." However that may be, the march of material progress is not easy to measure.

Under the vigorous control of Cromwell there was a short periok of uplift clearly traceable to his own iron hand. This is perhaps the last oceasion when this country received any aid in its development directly as a benefit from any one person in supreme control. Scotland had never been so fortunate as to have many with the eapacity and position to confer blessings of this heroic nature. Slowly, but surely, she has been able to work out her own destiny and develop her own eivilization, almost entirely unassisted by centrifugal forees springing from antral authority. Sill the absence of that central authority, which the pure hazard of fate made it her lot to andure, was not without marked retarting power for a long time. Seotland and Fngland are almost alike in haring dereloped, prior to the nineteenth eentury, respectable and representative governments by themselves and from their own poople. England and Scotland, anterior to about the seventeenth century, were both very greatly affected by the persomnel of their lings or regents, but not antirely so, not quite so much so as continental countries. Both kingtoms gained in parliamentary strength and importance under weak and inefficient sovereigns, hut in this respect England notably exceded her northern neighbour.

After the serenteenth century both England and Seotland made almost constant political, material, and social progress in spite of comparatively weak rulers. This later history of scotland, requires, I think, no further detailed 
analysis just here. One searches for the royal influence but one finds it comparatively $\mathrm{nil}$. Other forces come into play which raised the whole mass of the population, or at least a considerable portion of it. Here the king stepped out, the commoner stepped in.

Let us not be rash in jumping to a conclusion as to the cause of this important change. Let us not suppose that the usual references to the spread of education and the growth of political liberty will suffice. The question of the rise of the commoner in northwestern Europe is an interesting one, and looked at in a broad way, it is one of the most extraordinary and unparalleled phenomena in the whole history of the world; but we have scarcely begun to measure those forees, biologieal and political, both internal and external, hereditary and environmental, which, hidden and complieated as they are, can yield to disentanglement only by the prolonged investigations of science. Questions like the rise of the commoner in modern Great Britain had better be left for future investigation. 


\section{CHAPTER XVI}

\section{ENGLAND}

Of all European nations, not one can show such growth and progress unassisted by sovereign aid as England. From the days of Magna Charta, and even before that memorable event, there were already to be seen movements beneath the surface, indications of the coming forth of a nationality which was to show a type of organic structure new to the history of the world. As the centuries have done their work many other nations have become transformed, evolving into aggregations patterned more or less elosely on the constitutional form, but the first rudiment of this new growth must always be sought somewhere among the tap-roots of the Anglo-Saxon race.

The republics and democracies, so-called, of antiquity, the Cireek and Roman modes of political control, the small societies and independent cities, variously organized and more or less democratic in character, bear but slight analogy to the great constitutional nations of to-day. The theory of widespread suffrage, that all classes and all sections shall be represented in sovereignty, finds its origin in the Witenagemot of the Anglo-Saxons or perhaps in the assemblies of the Teutonic tribes, not in the Roman senate or the Greek ecclesia.

England is proverbially "the Mother of Parliaments," and her history presents excellent opportunity of observing and recording those forces which are the reverse of that single force which it has been the aim of this book systematically to record and measure. I shall not attempt to discuss the causes of this important difference, or try to explain why the history of England exceeds all other mo190 
narchical histories in offering exceptions to my main thesis. It would lead, if justice be done the subject, into a multiplicity of debates over questions alien to my present inquiry. It would strain the sciences of anthropology, psychology, and sociology, and all the theories of civilizing influences, from ethical to climatic; yet agreement would scarcely be reached. In fact, I do not believe that the special science of treating historical causation has yet reached a stage to make such speculation profitable, exeept in so far as suggestive diseussion may sometimes have a stimulating value for the interest aroused.

I shall do no more than review briefly the well-known facts of English history, systematically calling attention to each point indicative of a ruler's import, just as I have done for other countries. I shall also be at pains to point out each instance of progress under weak sovereigns. These rare periods, once fixed and limited, beckon one on to further research, to deeper analysis of their underlying causes and to the hope of discovering factors common to them all. I shall show that there have been an exceptionally large number of able political men in England as compared to other countries, and their names will be referred to in passing, though only in the way of mentioning those who seem the more important. ${ }^{1}$

The influences of the kings themselves remained, however, a most important force even down to Stuart times. It is strange that so few historians have realized the personal weight of Norman, Plantagenet, and Tudor kings. Many individual authors, specialists in their various fields, have felt the ponderous personalities of such men as William the Conqueror, Henry II, Edward I, Henry VII, and Henry VIII. Indeed, it is rare to find an historian who does not unhesitatingly ascribe to each of these kings, undividually, an immeasurable importance in the history of his time. Yet,

1 It would not be difficult to make a special study of the influences of the great English statesmen on economic and political advanee along the lines and methods followed in these pages. 
when not focussed upon the kings separately and attentively, the same historians seem to wander and to overlook the importance of royalty as a generalized idea. Other causes are brought forth freely in a dogmatic manner, but the reader who desires proof will search in vain.

Two English historians, John Richard Green and William Cunningham, take cognizance of royalty as a prime factor, but only for the Norman and pre-Norman rule. Their assertions, which I will now quote, are the only generalized conceptions of the paramount importanee of royal leadership which I have happened to run across in any of the standard histories. Croen's remark refers especially to the eleventh and twelfth centuries. In referring to the Danish and Norman rule he says: "Time for the varied progress was gained by the long peace which England owed to the firm government of her kings, while their political ability gave her administrative order, and their judicial reforms built up the fabric of her law. In a word, it is to the stern discipline of these two hundred years that we owe not merely English wealth and English freedom, but England itself."

It might be remarkel, by way of comment, that immediately before the Conquest and afterwards in the middle of the twolfth contury during the reign of the weak Stephen, there was neither law, nor order, nor progress; and as for the last clause, I eannot refrain from a more vigorous protest. There is not a grain of proof that the "stern discipline" of one period can be carried along in its influence so as to be still effective on even one subsequent generation, much less on several. Numerous instances could be cited from the history of Spain, Portugal, Prussia, France, Russia, ete., to disprove such an idea, - a typical dogmatism, and in conflict with recent biologieal beliefs. Entertaining as such writers' ideas are from the literary point of riew, they have a pernicious influence on the sciences of historical philosophy and race psychology. Of course I should also contend that neither Green nor any one else could 
know from the study of English history by itself whether the kings had any influence or not. The field would be too narrow, the number of instances too few, and the comparative standpoint lacking. Out of a score of historians, some devoted to one set of causes, some running after another, Green and Cunningham happen to favour kings, at least for the early period. They are right and the others have overlooked a tremendously important factor; but the proof comes only in the form of high probability printed in more or less impressive type, and drawn from the observation of the repetition of similar instances over and over again in other lands where all the other factors, save this one factor, are changed, but where the human relation between herd and leader remains the same.

The statement of William Cunningham is explicit and worth quoting in full from "The Growth of English (History) and Commerce," page 121. "Of all the cant which is current in the present day about history, none is more pernicious than that which despises the story of real personages and real events, and busies itself about abstractions which tell us that it is not eoncerned with kings and battles but with the life of the people. It is true indeed that in modern times the life of the people ean be treated apart from the consideration of the personal character of George IV or William IV. But in the Norman reigns this was not the ease ; security for person and property, intercourse with other nations and commercial advance were directly connected with the personal character of the king; the life of the people was most deeply affected in every way by the strength or weakness of his disposition. It would be interesting to try to explain the reasons of this change, and to show why the personality of the king, which was so allimportant long ago, is of comparatively little moment now; but it is merely idle to ignore the fact or to try to understand the history of the Norman reigns without taking it into account." 
This paragraph is the only statement I have found closely embodying my own theory. Its uniqueness shows how very unfashionable the "great-man" view of history has become. Cunningham makes no effort to bring proof to support his eonvietion that the life of the people was most deeply affected in every way by the strength or weakness of the king's disposition. Perhaps the historian deserves credit, who in default of any scheme for presenting real proof, disdains the pseudo-seientific habit of eiting a few examples favourable to his theory. His remark that it would be interesting to try to explain the reasons why the personality of the king, which was so all-important long ago, is of comparatively little moment now, is delightfully scientific in its unassuming attitude and desire to know the truth. One too rarely finds in historial writings such words as "it would be interesting to try to explain the reasons." Usually the reasons flow gratuitously enough. In saying that the personality of the king is of eomparatively little moment now, Mr. Cunningham is referring, I take it, to England solely; but it might give a reader the belief, unconsciously enough, that the same is true everywhere, even outside the English-speaking race. As a matter of fact the differences on this score between some eountries and others are among the most important points that I have been able to bring to light.

This calls to mind what is perhaps the chief reason for the unwarranted neglect of the "personality" theory of history at the present time. To so many, the history of civilization means western eivilization and the development of liberty means English liberty, that they are blind to the really exceptional nature of the very happenings and tendencies which interest them most. The expansion of the democratic idea, the growth of parliament, and the development of constitutional government are not the less glorious, conceived also in the light of their modernness. If the history of most European eountries, as late as the nineteenth century, and indeed England itself during the Middle Ages, 
favours a doctrine the opposite of democratic in its tenor, these facts are the more worth bringing together as soon as other facts can be placed against them in contrast; for it is by the appreciation of significant differences, the rearrangement and grouping of like facts with like, that a basis for an analytical and descriptive science is obtained.

The history of England as a distinct nation begins so definitely with the year 1066 that this date serves as the natural starting-point for the present outline. The Norman Conquest ushered in one of the great celebrities of the world's history. William I was not a mere ereature of circumstances. Evidences of his genius are at every hand. No authority on the period of the Conquest, so far as I am aware, has ever raised the question or entertained the least doubt that William the Conqueror was anything less than a man of genius. Precociousness of talent, something difficult to explain in any other way than through inherent composition of the germ-plasm, is often a concomitant of genius, and William showed precociousness to the extreme. As sole though bastard heir to Robert of Normandy, he had inherited that duchy in accordance with his father's wish; and being but a boy of eight, a guardianship was at once appointed. The wildest anarehy accompanied his boyhood years. In no part of the world were the barons stronger or more disposed to lawlessness than in those dominions afterwards compacted into the French nation. Three of the guardians of the youthful duke had been murdered in rapid succession. William had been hidden away in order that he might escape a similar fate. About the age of sixteen he began to emerge from obscurity and to act in a way indicative of that growing spirit of mastery which was to make him in the end one of the most feared of men. By the time the duke was twenty he had taken upon himself the supreme control and had settled, by the decisive battle fought at Val-des-Dunes (1047), the question whether he should rule the nobles or the nobles should rule him. 
Before his twenty-third year, William had sufficiently disembroiled Norman affairs to be able to cast his eye towards the English crown, and in 1051 he made a visit to Edward the Confessor with the idea of strengthening his claim and obtaining a promise of the succession. It will be unnecessary here to rehearse the particulars of the Norman Conquest or the changes which came over England, ushered in by that important event. All I wish to emphasize is the uniform way in which criticism pays homage to the remarkable qualities of William, thus making the period 1066 to 1087 reflect the sovereign quite at the maximum rate.

"Whoever dwelt in the land, Englishmen, Normans, or any other, William was their master and moulded them to his will. A less discerning eonqueror might have made simple havoc of all that he found established in the land which he conquered. A man of meaner mould might have indulged in mere paltry and wanton tyranny. But William neither changed one whit nor tyrannized one whit beyond what his position and purposes demanded. His position as Conqueror, combined with that eraft in which none could rival him, enabled him to put the final seal to the work of Eagbert, of Eadward, and of Ethelstan and make England one United Kingdom, which, since his days, no man has ever dreamed of dividing." 1

"He was a man of iron will and remarkable genius; no consideration could divert him from the pursuit of his aims and he was unscrupulous as to the means he employed to attain them. Though not delighting in human eruelty he was callous to human suffering. In addition to his two signal acts of cruelty he amassed great riches by oppression and became avaricious. Assertions that he had any illegitimate children or that he was unfaithful to his wife lack historical basis. But the characteristic by which he is most distinguished from the other men of his time is one which he shares with many of the eonquerors of history - a char-

${ }^{1}$ E. A. Freeman, "Norman Conquest," iv, 18. 
acteristic indispensable to that kind of success - an utterly relentless determination to succeed, if necessary without hesitation at the means employed, and without considering in the least the cost to others." 1

"Violence was common and there were but few signs of advancing prosperity or civilization when an entircly new set of influences came into existence with the Conquest." 2

"The contests of the years immediately following 1066 led to a sort of period of decay, but very soon inereasing trade and handicraft led to still greater progress. London especially made good its position as one of the great cities of Europe and that preëminence among English towns which it has never lost." 3

J. R. Green summarized the situation thus: "It was in fact this vigorous personality of William which proved the chief safeguard of his throne." "Stark he was," says the English chronicler, "to men that withstood him; earls that did aught against his bidding he cast into bonds; bishops he stripped of their bishoprics, abbots of their abbacies. He spared not his own brother; first he was in the land but the king east him into bondage. If a man would live and hold his lands, need it were that he followed the king's will. But stern as his rule was, it gave peace to the land. Even amidst the sufferings which necessarily sprang from the circumstances of the Conquest itself, from the erection of castles, or the enclosure of forests, or the exactions which built up the great hoard at Winchester, Englishmen were unable to forget the 'good peace he made in the land, so that a man might fare over his realm with a bosom full of gold.' Strange touches of a humanity far in advance of his age contrasted with the general temper of his government. One of the strongest traits in his character was his aversion to shed blood by process of law; he

1 "Dictionary of National Biography."

2 E. P. Cheyne, "Industrial and Social History of England."

I Ibid., p. 17. 
formally abolished the punishment of death, and only a single execution stains the annals of his reign. An edict yet more honourable to him put an end to the slave trade which had till then been earried on at the port of Bristol. The pitiless warrior, the stern and awful king, was a tender and faithful husband, an affectionate father. The lonely silence of his bearing broke into gracious converse with pure and sacred souls like Anselm. If William was 'stark' to rebel and baron, men noted that he was 'mild to those that loved God.',

Archbishop Anselm figures conspicuously in the following reign. He did not immigrate to England until after the Conqueror's death. Another prelate, Lanfrane, born also in Piedmont, is the man who of all others towers in the multitude, second only in eminence to the king himself.

William II (Rufus) likewise stands as a king whose influence on the affairs of his time must be reckoned paramount. Tyrannical and godless beyond all bounds, a wild and erratic half-genius, all the strange and exceptional traits of the "Red King" are reflected in the principal features of his reign. An overpowering will preserved good order throughout the land, no other than he himself was allowed to rob, while profligacy, extravagance, pride, and ambition exhausted the royal purse. The English people were oppressed in this reign more than ever before or since, and few kings in any country have been equally wicked and at the same time abundantly endowed with all talents necessary for the maintenance of a position of supreme and diabolical power. William Rufus was impossible to repress; at least it appears that no single person or combination of persons came forward in this reign, as they did for instance in the reign of John, to deliver the nation from its insufferable burden. The revered Anselm attempted some check on the king's demoralized actions and rapacious seizure of Church property and Church governance, but the worthy old archbishop was forced to bow his head. He resigned his post and left 
for the Continent. The good people marvelled that so bad a man could continue to challenge the wrath of God and yet prosper so persistently. The king was a good fighter in every sense. Some say that as a soldier he was little inferior to his father. This counted a good deal in England's favour and realized itself in many conflicts, the successful issue of which led to the amalgamation of those various elements which the Conquest had but recently half welded together. The crushing out of the turbulent baronage, the quick suppression of Scotch inroads, and the settlement of the northwestern frontier were of great praetical value to the future development of England; and the insular power is now seen for the first time reversing history and appearing on the Continent in the guise of the aggressor.

The next Norman king was not inferior in energy and determination of purpose to his father, the Conqueror, or to his brother Rufus. Henry I was a good, we might say excellent, soldier, but he was essentially a man of peace; he preferred the wily arts of diplomacy to those of war, and his long reign was very successful. The personality of the king is to be observed in all the most important features of the reign. First, his practical sense and good judgment is to be seen in the famous charter of liberties which was granted immediately on accession. The strong mailed fist was not lacking to keep good order in the land. The learned mind initiated the new courts of justice. His temper drew him away from ambitious and unnecessary wars, and a long period of peace at home gave England a chance to develop her economic resources, so that the rather burdensome taxes were fairly well borne. The barons hated and feared him, but the peace and order which he established were greatly appreciated by the people. Henry I in his marriage with Edith-Matilda, and in all his subsequent actions, including the appointment to high office of new men not Norman in blood, did a great deal to bring about that fusion of the elements which so soon created the modern English race. The principal lieutenant 
of Henry I was the great justiciar, Roger, Bishop of Salisbury. In this reign Anselm figures again, but his influence is more confined to matters ecclesiastical.

In 1135 the sceptre passed into weak hands, and for the first time in seventy years constructive social forces turned into disintegration. The debacle under Stephen is in every way as pronounced as the typical weak periods found in the history of countries other than England. Stephen who was active, ambitious, and well-meaning, rushed around the country here and there, attempting to conciliate all parties. It was a clear case of simple lack of ability. Stephen was no fool. Very likely he was quite the equal of the average baron of his day. Such scenes of anarchy and misery as this reign pictures only bring out in stronger relief those colossal figures who were able to hold their leadership and enforce an iron order on an unwilling baronage.

The next sovereign, Henry II, fitted more in the mould of the Conqueror. Henry II was a very strenuous person. Though not usually counted among the greatest of world geniuses, an intimate study of his make-up and his career compels full admiration for his capacities, and at the same time vividly flashes before the mind how truly great the great kings were, when here is one who stands somewhat below the very highest grade. For this reason I will show as a specimen that a collection of quotations from the standard historians paints a portrait of a man who, if only a king among kings, was certainly a giant among men. ${ }^{1}$

"Young as he was, Henry mounted the throne with a resolute purpose of government which his reign carried steadily out. His practical, serviceable frame suited the hardest worker of his time. There was something in his build and look, in the square, stout frame, the fiery face, the close-

${ }^{1}$ It is scarcely necessary to add that the method pursued in bringing these accounts together is impartial in its aim. I have, of course, selected only those paragraphs which best convey the picturesque impression, but I can fairly state that no statements have been met with which could be taken as refuting these opinions. 
cropped hair, the prominent eyes, the bull neck, the coarse strong hands, the bowed legs, that marked out the keen, stirring, coarse-fibred man of business. 'He never sits down,' said one who observed him closely; 'he is always on his legs from morning till night.' Orderly in business, careless in appearance, sparing in diet, never resting or giving his servants rest, chatty, inquisitive, endowed with a singular charm of address and strength of memory, obstinate in love or hatred, a fair scholar, a great hunter, his general air that of a rough, passionate, busy man, Henry's personal character told directly on the character of his reign. His accession marks the period of amalgamation, when neighborhood and traffic and intermarriage drew Englishmen and Normans rapidly into a single people. A national feeling was thus springing up before which the barriers of the older feudalism were to be swept away. Henry had even less reverence for the feudal past than the men of his day; he was indeed utterly without the imagination and reverence which enable men to sympathize with any past at all. He had a practical man's impatience of the obstacles thrown in the way of his reforms by the older constitution of the realm, nor could he understand other men's reluctance to purchase undoubted improvements by the sacrifice of customs and traditions of bygone days. Without any theoretical hostility to the coördinate powers of the state, it seemed to him a perfectly reasonable and natural course to trample either baronage or Church under foot to gain his end of good government. He saw clearly that the remedy for such anarchy as England had endured under Stephen lay in the establishment of a kingly government unembarrassed by any privileges of order or class, administered by royal servants, and in whose public administration the nobles acted simply as delegates of the sovereign. His work was to lie in the organization of judicial and administrative reforms which realized this idea. . . .

"There is no ground for thinking that Thomas Becket in any degree influenced his system or rule. Henry's policy 
seems for good or evil to have been throughout his own. The work of reorganization went steadily on amidst trouble at home and abroad." 1

"Justice and peace, in the sense which these words conveyed to the men of his day, were to be the main characteristics of his reign in England. The old machinery of justice, of finance, of general administration, was at work again. Yet the work that he did for England was only the part of his work that outlasted his own life, and it has lasted for seven centuries. It was by his power that England, Scotland and Ireland were brought to some vague acknowledgment of a common suzerain lord. It was he who abolished feudalism as a system of government and left it little more than a system of land tenure. It was he who defined the relations established between Church and State, and decreed that in England churchman as well as baron was to be held under the common law. It was he who preserved the tradition of self-government which had been handed down in borough and shire-moot from the earliest time of English history. His reforms established the judicial system whose main outlines have been preserved to our own day. It was through his 'constitutions' and his 'assize' that it came to pass that all over the world the English-speaking races are governed by English and not by Roman law. It was by his genius for government that the servants of the royal houschold became transformed into ministers of state. It was he who gave England a foreign policy which decided our continental relations for seven hundred years." 2

"Of all kings between the Conqueror and Edward I he has the best right to the name of law giver. . . . Within the island world of Britain the power of England rose for a moment under Henry II to a greater height than it had ever risen at any earlier time.", 3

1 Green's "History of the English People," pp. 197, 198, 199.

${ }^{2}$ Kate Norgate writing in the "Dictionary of National Biography."

${ }^{3}$ E. A. Freeman writing in the ninth edition of Encyclopædia Britannica. 
"Foreign affairs were undeniably successful. He held France in the hollow of his hand. He built up and kept together in a marvellous manner a Continental dominion." 1 "The legislation of his reign was probably in great part of his own contriving. His supervision of the law courts was close and jealous. He transacted a great amount of judicial business in his own person even after he had formed a high court of justice which might sit without his personai presence. To these activities he devoted his scanty intervals of leisure. His government was stern; he over-rode the privileges of the baronage without regard to precedent; he persisted in keeping large districts under the arbitrary and vexatious jurisdiction of the forest courts. But it is the general opinion of historians that he had a high sense of his responsibility and a strong love of justice; despite the looseness of his personal morals, he commanded the affection and respect of Gilbert Foliot, and Hugh of Lincoln, the most upright of the English bishops." 2

"Whatever may be said against his private character, the wisdom and steadiness with which he pursued these aims, and the permanence of the mark that he left upon the constitution, secure him the title of a great king." 3

The next English king is one who always appeals to the popular imagination. The relations of Richard Cœur de Lion to his home country, were, however, very unimportant, compared with many sovereigns of an carlier and later date. Spending most of his time in foreign lands, perhaps the chief and only way his personality is directly mirrored in domestic affairs is that a continual drain was placed upon the exchequer which had to be met by high taxation. The king departed for the Great Crusade in the summer of 1190, just after his accession. Then he spent something over a year in captivity. The remainder of his

\footnotetext{
1 Sir J. H. Ramsay, "The Foundation of England," pp. 248, 257.

2 H. W. C. Davis, Encyclopædia Britannica, 11 th edition.

s G. W. Prothero in Encyclopædia Britannica, 9th edition. 
reign was chiefly taken up in warfare with Philip Augustus of France. Richard was only twice in England for a few months during his entire sovereignty. The country was ruled, and ruled wisely, by three or four ministers or justiciars.

This is a very important point, as it signalizes one of the earliest proofs of England's fitness for self-government, for constitutionalism and autogenous growth. The machinery so well set up by Henry II continued at work. The bureaucrats acted honestly and the barons remained remarkably peaceful. Important constitutional advances took place, and despite the onerous demand for taxes, wealth seemed to have been increasing and the general picture of England at that time is far from gloomy. I will not attempt to discuss the causes for the phenomenon. I merely call attention to the period as a very early indication of an advance non-royal in character. The more eminent men of this decade were William of Longchamp, Walter of Coustances, and Hubert Walter. The last, decidedly the greatest of the three, held the offices of chief justiciar and Archbishop of Canterbury. He was a relative of Ranulf de Glanvill, the great justiciar of Henry II. Any minister had a difficult task at that time to stand between the king and his people and to satisfy the constant demands for money, most of which was intended to be sent outside of the kingdom. Hubert Walter not only managed taxation in an honest way, but appears as the true originator in England of the principle of representation and election for public service; the election of coroners or registrars of the "pleas of the crown," and more important, the use of juries to decide on questions of assessment and taxation. The knighthood class rose in power, and, taken all in all, the reign of Richard I was very fruitful in the growth of institutions favourable to popular liberty.

The reign of John also illustrates, and in a well-known way, the early English determination not to abide a sover- 
eign who should carry tyranny too far. John may or may not have been intellectually superior; there is some disagreement as to this side of his make up, but as far as his moral character is concerned, there is but one verdict.

"All the vices of his house appear in his character unredeemed by any greatness. He was mean, false, vindictive, and abominably cruel. At once greedy and extravagant, he extorted money from his subjects and spent it in an ignoble manner. He had a violent temper and a stubborn disposition, but he lacked real firmness of mind and was at heart a coward. Although not without capacity, he was so frivolous and slothful that at the most critical time he behaved like a fool.... He was self-indulgent and scandalously immoral." 1

" "Foul as it is, hell itself is defiled by the fouler presence of John.' The terrible verdict of the king's contemporaries has passed into the sober judgment of history." 2

"John's lack of insight was on the moral side, not at all on the intellectual. . . . It is of some interest that in all the contemporary discussion of this case no one ever suggested that John was personally incapable of such a violation of his oath or such a murder with his own hand. He is of all kings the one for whose character no man, of his own age or later, has ever had a good word. Historians have been found to speak highly of his intellectual or military abilities, but words have been exhausted to describe the meanness of his moral nature and his utter depravity ... his utter falsity, the impossibility of binding him, his readiness to betray any interest or any man or woman, whenever tempted to it." 3 George Burton Adams, author of this paragraph, makes the comment before closing his account of John, that the failure of modern students to find redeeming features assures us of their absence.

1 "National Biography," Rev. William Hunt.

2 Green's "Short History," p. 231.

${ }^{3}$ Hunt and Pool, vol. II, pp. 401-403, section written by G. B. Adams. 
The personality of this king gives the student of royalty a lowest mark for the development of moral character and a prototype of all that royalty may be at its very worst. This furnishes, therefore, a valuable point of departure and gives aid in estimating and grading kings not quite as bad as John, - those possessed of some redeeming virtues. Thus the compiled and systematically arranged opinions of authorities fit the law of probability, because there should be theoretically only one or two, a very few at most, out of a large number of kings (or other individuals) who inherit no good qualities whatever. There are so many traits that are generally accounted good, that some at least will reach almost every one.

This gametic view of John's character which I here suggest will be understood by an analogy. It is as if in a large assembly, black, gray, and white cards were dealt out twenty to each. There would be, say, only one person who would receive all black. Such a one was John. Of course this would be carrying it a little too far, as it is impossible to believe that some moral traits of John's were not at least gray, but it matters not as far as my point is concerned; which is to show that King John was thoroughly bad, according to all accounts, that one or two such monsters are to be expected, and that having this agreed upon, one is more inclined to believe what is said about the others who are not quite so wicked, and who increase in frequency until the average type is reached.

King John's influence on the England of his time was not unimportant. At the close of the reign the situation was one of dire calamity. For this the king himself seems chiefly to deserve the blame. Yet this reign is marked by common consent as the time from which Englishmen and English descendants first date their chartered liberties. Although most of the Magna Charta was but a recognition of principles already won in earlier reigns, the significance of the meeting at Runnymede is such, that both in its intellectual 
and material bearings this event may be felt to outbalance the adversities and afflictions of a tempestuous reign.

The importance of Magna Charta was much exaggerated in later ages, and doubtless its importance is in no way commensurate with its fame; but in the pages of a special study like the present, the happenings of the year 1215 in England are unparalleled, or at least unprecedented, and are very provocative of thought and theory. Some great historical movements have their obvious leaders, who may have been the initiators or may themselves been the product of their times. Other movements seem to generate en masse. The winning of the Magna Charta appears to belong to the latter category. It must not, however, be supposed that the people, as a whole, or even a large part of the middle or upper middle classes either demanded the Great Charter or got much out of it. It was a demand springing from the great clergy and the barons, and designed by them to benefit themselves. Stephen Langton was the most prominent among the prelates and Robert Fitzwalter was leader of the barons. The latter appears more in the rôle of agitator; he was not a great man, at least judged by his subsequent career. Stephen Langton, however, takes hold upon the fancy. The record of his life portrays a man of genius. Perhaps if a "soul of the movement" is to be unveiled in any one person more than another it must be identified with the Church primate, Stephen Langton. The baronial party had another really great man in William Marshall, Earl of Pembroke. His name is especially mentioned in the preamble along with a few other prominent persons, but there is nothing to connect this statesman with leadership in the events anterior to the meeting and signing of the Charter.

Be all this as it may, there is one feature of the whole situation which no one should fail to notice, and that is that here was concerted action. One can espy many places in the tables which are printed in the Appendix of this volume where villainous, incapable, and tyrannical kingship ought to have 
led to happenings similar to those in England in 1215. For instance, one can cite from France, the reign of Philip I, Philip IV, and his three sons, Philip VI, John II, Charles VI; from Castile, Uracca, Peter the Cruel; from Portugal, Ferdinand I, - from Scotland, David II; from Denmark, Eric (1412-1439); from Sweden, Eric XIV and John III ; from Russia, Basil Shuiski (1606-1610) and Sophia (1682-1689); from Turkey, Murad III (1574-1595), Mahommed III, and Osman II. Not but what other reigns show disturbed conditions, weaknesses that needed to be taken well in hand, great wrongs endured by the masses that called for aid yet did not receive it; but these sovereigns here enumerated are the ones who most resemble King John of England. These instances show that intolerable tyrants do not give rise to concerted action on the part of the oppressed. To say that England gained constitutionally because of John's wickedness does not reach the heart of the matter. It does not pick out the peculiar point of difference. England gained at this point because of something inherently peculiar in the English baronage of that time, or in a small number of them, or in one of them, or in the special circumstances of the situation. The problem is open for further enlightenment. I shall show later that the last of these suppositions is rendered highly improbable by subsequent historical developments.

The short period directly following the death of John (1216-1219) furnishes an instance of a minority not retrogressive in its tendency but quite the contrary. The single man responsible for all this, William Marshall, Earl of Pembroke, was exceptionally great and good, a loyal and noble character, as is shown through all the deeds of a varied and brilliant career before he was made "Governor of the King and Kingdom."

"His regency was the worthy finish of his long life. The great and special work of Marshall was the pacification of the realm after the period of disorder. This task he accomplished 
by the firm but conciliatory policy of his three short years of rule, and it is because he thus made possible the realization of the charters that he deserves an honorable place among the founders of English liberty." 1

"The expulsion of the French, the restoration of order, and the securing of the validity of the Great Charter by successive and solemn confirmations were the chief debts that England owed to William Marshall." 2

The remaining years of Henry III's minority were also progressive though not quite so much so. Control of the government was divided under a sort of triumvirate, of which the justiciar, Hubert de Burgh, was ehief, and of which the papal legate, and Peter des Roches were members. In Hubert de Burgh England had found another able champion of the public welfare.

Henry III, however, failed to appreciate a man who might have saved him from many misfortunes. In 1232 he deposed the justiciar and took affairs into his own hands. His reign of fifty-six years is from the constitutional side one of considerable importance inasmuch as it initiated in England the practice of calling together parliaments in which various classes and sections found representation. This must be counted as far as it goes towards political betterment, and therefore of influence on material affairs. In addition it must be said that the cra of Henry III was not a time of economie decline as is sometimes stated. The English people were very heavily taxed and for purposes foreign to their own interests. The royal revenues were squandered and the nation sunk in debt, but it does not appear that in wealth and civilization the people were not better off at the end of the reign than at the beginning. This might naturally be expected as a part of the world movement of the thirteenth century which was very productive in many quarters of Europe.

I "Dictionary of National Biography."

2 Stubbs, "Early Plantagenets," p. 170. 
Certainly the good side of the reign was not due to King Henry III or the royal favourites. Their influence is clear enough. They are responsible for the maladministration, while the good features spring from the people as a whole, or at least a considerable number of persons, or perhaps from other causes. Simon de Montfort, more than any other one man, is entitled to the eredit of leadership, but the whole movement seems to spring more from concerted action than from the inspiration of a solitary genius. For many years the policy of the king had been opposed by many of the wiser and more patriotic men of prominence, including Edmund of Abingdon, Robert Grosseteste, and Richard, Earl of Cornwall. It was only after Earl Simon took up the good cause that anything was actually done to assuage the sufferings of the nation. The parliament of 1258 and the legal limitations, placed upon the monarch at this time, were in the direction of reform, but they failed to furnish the only real remedy, which meant the actual scizure and restraint of the king himself. This was accomplished at Lewes, 1264, where a minority of the barons under Montfort's skilful generalship won the day. For the rest of his life, until 1272, Henry III was kept in confinement or under tutelage, and his name disappears from English history. After the death of Montfort at Evesham, Prince Edward became the real ruler of the kingdom.

Just how great a part Earl Simon "the Righteous" played individually in delivering the people from a wretchedly incompetent king one might hesitate to say. To my mind the most interesting aspect of the reign of Henry III is the unexpected nature of its successful termination. It is missing the mark widely to think that the weakness of the king and the insufferable irritation which his ill-advised policy had aroused among all classes of citizens was the cause of his eapture and downfall. Of course in one sense it was a cause, because if he had been great and wise surely all this would not have happened. But weakness in a king at that period (say 
between the tenth and seventeenth centuries) usually did not find itself followed by a like result. Let one pick out the rulers of that age who most resembled Henry III and see how many instances one can find where popular liberty advanced. As examples of incompetent sovereigns under whom constitutional advance should have taken place but did not, I will cite Robert II, Philip III, and Louis X of France; Ferdinand IV, John I, and John II of Castile; Ramiro II and Alfonso IV of Aragon; Alfonso V of Portugal; James III of Scotland; Christopher III and Christian I of Denmark; Feodor I of Russia, and George William of Prussia. Besides these, one can point to Edward II and Henry VI of England. Against these sixteen instances of failure on the part of nobles (or the people) to exact constitutional advance, I ean find but three instances outside of England where a growth took place somewhat like that under Henry III. Under Louis VII of France that concessions were granted to townspeople and to the lower classes. Under Robert III of Scotland, in spite of the general lawlessness, parliament is to be accredited with the passage of certain new statutes favourable to the masses. And under Mary of the Netherlands the people were able to gain their important "Great Privilege" of 1477. All this shows that the really significant and peculiar cause for the sueeessful and valuable features of the reign of Henry III lies somewhere not far from the eharacter of Simon de Montfort or others closely associated with him and high up on the social ladder. That it was not due to the temper of the English people as a whole is at least disputed if not disproved by the long parliamentary lethargy from Henry VI's reign onward, lasting as it did nearly two centuries.

Edward I, who already came to the front as a national hero, in his father's lifetime, saved the royal party, and did much to restore the nation to tranquillity, though he was still a mere youth of twenty-five or six. He did not disappoint his early promise, but developed into one of the greatest kings England has ever had. The many economic and political influences of 
Edward I are always freely recognized by English historians. It is only necessary to consult the most easily accessible accounts, to see that authors writing without any generalized theory of genius and its influence do not fail to appreciate the special significance of King Edward I. Let me merely quote some paragraphs written by Professor C. W. C. Oman in the article on "English History" in the new Encyclopædia Britamnica: -

"Edward I was a remarkable figure, by far the ablest of all the kings of the house of Plantagenet. He understood the problem that was before him, the construction of a working constitution from the old ancestral customs of the English monarchy plus the newer ideas which had been embodied in the Great Charter, the Provisions of Oxford, and the scanty legislation of Simon de Montfort. Edward loved royal power, but he was wise in his generation and saw that he could best secure the loyalty of his subjects by assenting to so many of the new constitutional restraints as were compatible with his own practical control of the policy of the realm. He was prepared to refer all important subjects to his parliament, and (as we shall see) he improved the shape of that body by introducing into it the borough members who had appeared for the first time in Montfort's assembly of 1265. He would have liked to make parliament, no doubt, a mere meeting for the voting of taxation with the smallest possible friction. But he fully realized that this dream was impossible and was wise enough to give way whenever opposition grew too strong and bitter. He had not fought through the civil wars of 1263-1266 without learning his lesson. There was a point beyond which it was unwise to provoke the baronage or the commons, and, unlike his flighty and thriftless father, he knew where that point came. The constitutional quarrels of his reign were conducted with decency and order, because the king knew his own limitations, and because his subjects trusted to his wisdom and moderation in times of crisis.

"Edwardindeed was a man worthy of respect, if not of affection. 
His private life was grave and seemly, his court did not $\sin$ by luxury or extravagance. His chosen ministers were wise and experieneed officials, whom no man could call favourites or accuse of maladministration. He was sineerely religious, self-restrained and courteous, though oceasionally, under provocation, he could burst out into a royal rage. He was a good master and a firm friend. Moreover, he had a genuine regard for the sanctity of a promise, the one thing in which his father had been most wanting. It is true that sometimes he kept his oaths or carried out his pledges with the literal punetuality of a lawyer, rather than with a ehivalrous generosity of a knight. But at any rate he always endeavoured to discharge an obligation, even if he sometimes interpreted it by the strict letter of the law and not with liberality. A conscientious man aceording to his lights, he took as his device the motto Pactum serva, 'keep troth,' which was afterwards inseribed on his tomb, and did his best to live up to it. Naturally he expeeted the same accuraey from other men, and when he did not meet it he could be harsh and unrelenting in the punishment that he inflieted.

"To sum up his eharacter it must be added that he was a very great soldier. The headlong courage which he showed at Lewes, his first battle, was soon tempered by eaution, and already in 1265 he had shown that he could plan a eampaign with skill. In his later military career he was the first general who showed on a large seale how the national English weapon, the bow, could win fights when properly combined with the eharge of the mailed eavalry. He inaugurated the taeties by which his grandson and great-grandson were to win epoch-making victories abroad. . . .

"Despite the ehequered fortunes of his later years, the reign of Edward had been a time of progress and prosperity for England. He had given his realm good and strong governance; aceording to his lights he had striven to keep faith and to observe his coronation oath. He had on more than one occasion quarrelled with his subjects, but matters had never been pushed to an open rupture. The king knew how to yield, and even 
opponents like Winchelsea and the earls of Norfolk and Hereford respected him too much to drive him to an extremity. The nation, however much it might murmur, would never have been willing to rebel against a sovereign whose only fault was that he occasionally pressed his prerogative too far. Edward's rule was never oppressive; the seizure of the merchant's wool in 1297 was the only one of his acts which really caused fierce and widespread indignation. For his other arbitrary proceedings he had some show of legal justification in every case. It would have been absurd to declare that his rule was tyrannical or his policy disastrous. The realm was on the whole contented and even flourishing. Population was steadily increasing, and with it commerce; the intellectual activity which had marked the reign of Henry III was still alive; architecture, religious and military, was in its prime. He was himself a great builder, and many of the perfected castles of that concentric style which later ages have called the 'Edwardian type,' were of his own planning. In ecclesiastical architecture his reign represents the early flower of the 'Decorated' order, perhaps the most beautiful of all the developments of English art. In many respects the reign may be regarded as the culmination and crowning point of the middle ages. It certainly gave a promise of greatness and steady progress which the fourteenth century was far from justifying.

"With the great king's death a sudden change for the worse was at once visible. The individual character of the ling was still the main factor in political history, and Edward II was in every respect a contrast to his father. He was incorrigibly frivolous, idle, and apathetic; his father had given him much stern schooling, but this seems only to have inspired him with a deeply rooted distike for official work of any kind. He has been well described as 'the first king since the Conquest who was not a man of business.' Even Stephen and Henry III had been active and bustling princes, though their actions were misguided and inconsequent. But Edward II hated all kingly duties; he detested war, but he detested even more the routine 
work of administration. He was most at his ease in low company, his favourite diversion was gambling, his best trait a love for farming and the mechanical arts of the smith and the gardener."

The reign of Edward II in England is almost identical in its lawlessness, its misery, and its hopelessness with typical weak periods so frequent in other parts of Europe. There were no great and patriotic leaders in England at just that time. The prominent men, Gaveston, Thomas of Lancaster, Pembroke, the Mowbrays, the Despensers, were all lacking in capacity or character. Mere partisans in spirit, they wasted their own and the nation's opportunity in quarrels among themselves. This lack of leadership offers a suitable and satisfactory explanation why the reign of Edward II presents fewer favourable aspects than the reigns of Henry III or of John. No one seemed great enough to command the concerted action of parliament or harmonize the rival factions. During the whole period of twenty years there is but one progressive action to record. In 1322 the parliament which met at York gained the important constitutional advance that from that time onward no statute should be technically valid unless the consent of the commons had been obtained. In this way alone did the reign of Edward II differ from any other age of anarchy; and it is worthy of comment that even in such a blind and leaderless period as this, some success was gained, slight though it be, along a line for which England has been most famous.

The minority of Edward III (1327-1330) shows little change either for the better or the worse. The government was theoretically in the hands of a Council of State; practically, the queen and Mortimer exercised complete authority, but not to the credit of themselves or the nation which allowed the disgraceful pair to control its destinies. England, with all her spirit of freedom, her parliament, and her Council of State, unable to save herself from a wretched decay that had been eating into every portion of her being for more than twenty years, at last found a deliverer in a boy of eighteen. Exagger- 
ated as this may sound, it is no more than a recital of the facts of history. The date of the birth of an individual is no more clearly fixed than the date of the rebirth of England, on the night when the boy king, Edward III, secretly entered Nottingham Castle by the subterranean passage, took Mortimer prisoner, declared himself free from all guardianship, and commenced his work of restoring order. The period of Edward III (1330-1377) is one of the longest and most important in English history. In some ways it was very progressive, in others not so much so, but in most ways an expression and outgrowth of the king's own forceful, magnetic, but half-quixotic personality. Edward III was not so great a man as his grandfather, Edward I, not so broad and deep, but no one typifies better than he the real chivalry of the fourteenth century, knighthood without the veil of virtues read in by poets old and new. In all the clash of arms and brilliant fêtes, the English king outrivals all his contemporaries. The marvel of his age, the central figure, admired and even beloved by his subjects who willingly followed him in foreign wars. Edward himself liked to fight. This was enough, all others must rally to his standard. He knew how to blind the common eye in a blaze of glory or the "light that beats about a throne." And until he grew too old he was very successful. One thing is certain, England began to prosper again as in the days of Edward I. The restoration of order, giving of wise laws, the victories of Halidon Hill and Crécy were especially the result of the king's activities. Even in a very general way, the reign taken in its entirety seems as much an expression of Edward's own nature as do many reigns in other countries where the wilful and able, warlike and extravagant type of ruler brings victory to his country, stimulates economic life, wastes much of the public treasure, and perhaps overburdens the people by taxation. ${ }^{1}$

${ }^{1}$ The following sovereigns most resemble Edward III in being brilliant, energetic and warlike, magnificent in their tastes and not over-virtuous: Henry IV and Louis XIV of Frauce, the Emperor Charles V, Alfonso the Battler, James the Conqueror, James the Justice, and Peter the Great of 
For a few years before the death of Edward III the conditions in England had been far from satisfactory. Disasters abroad and domestic strife at home, with the work of the Black Death still unredeemed, the nation had to face exceptional difficulties when Richard II came to the throne, at that time but ten years of age. The Council which had been appointed to govern the country was not equal to the task. A great social uprising, partly political and partly economic, forms the most notable feature of the regency of Richard II; in addition to which, defeat after defeat met the English army abroad. The channel fleet, which in the early part of Edward's reign had won the important victory of Sluys, was now no more; and the French actually invaded Sussex and burned Rye and Hastings. The whole period (1377-1399) presents scarcely a single meritorious feature. Parliament, though it accomplished nothing in the way of bringing about coördination of rival interests, and hence a better practical administration, did gain something for its own internal development.

One picturesque happening, the turn in the tide of the peasants' uprising at the time Wat Tyler was killed, was directly brought about by the bravery and initiative of the boy king himself. He was then less than fifteen years old. The mob at Smithfield had lost their leader and were about to draw their bows, shouting, "Kill, they have slain our captain." "What need ye, my masters," cried the boy as he calmly cantered up and met them. "I am your captain and your king, follow me."

It seems probable that if Richard II had developed the character which this event foreshadowed, many of the evils and misfortunes of his reign would have been avoided. He did indeed show bravery and insight on many occasions, but his conduct was extremely undependable. He was nervous, fitful, head-

Aragon, John I of Portugal, James V of Scotland, Philip the Good of Burgundy and the Netherlands, Maximilian I of Austria, and Leopold who died in 1386, Charles X of Sweden, Suleiman the Magnificent of Turkey, and perhaps most of all Albert Achilles of Brandenburg. There are naturally points of difference but the general type is much the same, and the influences which they appear to have exerted have much in common. 
strong, easily elated, or depressed. "A creature of moods, and the moods always visited him at the wrong time. If he had not been thoughtless, arrogant and overbearing in 1398 he might have reigned for many a year. . . . Richard cannot be called cruel, nor was he a notorious liver, nor a thoughtless weakling. Nevertheless he fooled away the crown which kings intellectuually as well as morally his inferiors preserved to their deathday. . . No sovereign was ever more entirely the author of his own destruction." 1

The reign of Richard II's rival, Henry IV, was one of great confusion, ill-defined in its direction, filled with eivil wars, blights of nature, famine, and plague. Extreme poverty more than anything else characterizes the worst feature of this fourteen-year period, while diplomatic successes and the sturdy and praiseworthy behaviour of parliament must be reckoned on the side of progress. "We have no evidence of any wise counsellors on whom he could rely, and we are led to infer that, as he headed his campaigns in person, so he directed the coun(cils of the eountry without reference to any will but his own." 2

Henry IV is not reckoned among the great, but was at least a man of many excellent virtues, and on the score of energy must be placel in the first rank. He was brave in battle though cautious in politics. Few speak directly of his ability. In the words of J. R. Green: "The mere maintenance of his power through the troubled years of his reign is the best proof of the king's ability." By far the most singular and this far the most interesting phenomenon is the strength and action of parliament, especially as no eminent personalities emerge above the average nobleman or knight of the shire. "Never before and never again for more than two hundred years were the commons so strong as they were under Henry IV, and in spite of the dynastic question the nation itself was strong in the determined action of the parliament. All the intelligent knowledge of the needs of the nation, all the real belief in the king's title, is centred

1 Wylie, "History of England under Henry IV," vol. iv, p. 151.

2 It ylie. 
in the knights of the shire; there is much treason outside, but none within the walls of the House of Commons." 1

Henry V, the much admired hero of Agincourt, doubtless influenced history greatly, but the value of his conquests across the channel can hardly be thought to outweigh the national exhaustion which the long wars brought to England or the mischievous consequences flowing from the now continuous policy of pretension to the throne of France. It was a genealogieal and personal claim. It would seem that Henry sincerely believed that in foreing that claim he did only what was right. However that may be, all the ehief events and important changes, both for good and evil, sprang from the activities and interests of the king. Parliament and ministers sank into the background. At the time he mounted the throne, restoration of domestic peace was the most pressing need ; and the accomplishment of the same is unstintingly eredited to the firmness and prudence of Henry. He it was who first realized the importance of the British navy, and is generally regarded as its true founder. He took a very adroit position in relation to the schism in the Church, and shares with the Emperor Sigismund the eredit of bringing this long quarrel to an end in the election of Pope Martin V. Diplomatic success, the restoration of internal peace, the glory of external conquest, the wasting of men and money, which are the four cardinal points in expressing in rough form Henry I's ara, scem well enough to be the handiwork of the regal craftsman, the natural expression of a character quite elearly defined and described by all historians in much the same way. "A brilliant soldier, a sound diplomatist, an able organizer, a consolidator of all forces at his command. A typical mediæval hero." 2 "One of the greatest of warriors and statesmen." 3 "As a general he far surpassed all of his own time. As a diplomatist he was able, firm but conciliatory, and even in the midst of his busy warfare found time to form

'Stubbs, "Constitutional History," vol. iii, p. 72.

2 Stubbs, vol. iii, p. 75.

${ }^{3}$ Freeman, writing in the Encyclopædia Britannica. Q 
and maintain a system of alliances which included almost all the states of Western Europe, of which he was himself the centre. In work of civil administration he was less engaged, though in England he healed the animosities which had distracted the previous reigns." 1

Oman admires the moral character of Henry $Y$ somewhat less, but does not depreciate his intellectual caliber except to call his religious and diplomatic policy narrow. "Chaste, abstemious, patient, courteous, a good master and a faithful friend . . hard and narrow. . . In polities he saw elearly what was profitable to his dynasty, and sought that end unswervingly, unconscious apparently that a christian king has any duty towards his neighbours. . . He commands our intellectual respect but no one can call him sympathetic or a love-worthy character."

The minority of Henry VI (1422-1441) presents a picture rather different from any other minority. Cloucester, the king's uncle, was regent in theory, but all extra powers were taken away from him by the Council of State. Cloucester was fairly able, but self-sceking and unpatriotic; his influence was always in some pernicious direction. Bedford, the other uncle, was the big figure of the time, a fine character in every way. He was chiefly employed in carrying forward the war in France, which failed disastrously, seemingly through no fault of his own. It may have been typically one of those occasions when men find themselves helpless in the storms of fate; or whall we attribute the unusual outcome to one unusual and astonishing happening, - the advent upon the scene of the Maid of Orleans? Whatever view we may take of this historical episode, the scene remains unparalleled and at best not well understoor. The whole minority of Henry VI was inauspicious in the extreme. No good progress of any consequence can be cited. The entire nation seems under a cloud. Parliament acting as an oligarchy did nothing creditable, and even lost ground. Restriction of the right of franchise under the statue of 1429 made the commons

${ }^{1}$ Kingsford, writing in the "Dictionary of National Biography." 
less truly representative of the will of the middle-class freeholders and burghers. This disastrous period (1422-1444) does not reflect the influences of royalty in a straightforward way, since both Bedford and Beaufort (the latter a son of John of Gaunt) were able and patriotic princes; yet the personal element is not lacking. Probably no one would contend that these events could be understood apart from the behaviour of the various princes, most important of all being Humphrey of Gloucester, whose rôle was to thwart continually the more noble aims of the others. Bedford did well in his early eampaigns abroad. It was the evil machinations of the Duke of Gloucester more than anything else which prevented the successful continuation of the war, - at least from the standpoint of the English offence.

Looking on the other side of the conflict, on the question of French defence and French attack, Joan of Are completely turned the scales. France was in utter despair by the year 1429, just before Joan of Are appeared on the scene. Then Philip of Burgundy went over to the winning party. It was not until 1435, the date of Bedford's death, that the English cause was hopelessly lost by this transference of allegiance on the part of Philip from the English to the French side. Paris was abandoned the following spring. The Burgundian alliance, which weighed so heavily in the political scales after they had turned in France's favour, was clearly enough a "royal influence." Philip le Bon of Burgundy, a self-willed person if ever there was one, made every decision an expression of his own desires; and furthermore, no monarch in Europe was more powerful and able to carry out his every wish. Philip had very nearly bolted from the English cause at the time the same self-seeking Humphrey attempted to gain the inheritance of Hainault and Holland by marrying Philip's cousin, the countess Jacqueline. It was Bedford's tact that soothed the quarrel, and as long as he lived this stout old patriot was the mainstay of his party.

Thus the scenic changes of this more than usually confused minority are very much a matter of entrances and exits of the 
principal characters, - Bedford, Philip le Bon, Gloucester, Beaufort, and Joan of Arc. Other more general causes like the essentially strained and impossible nature of the struggle ought to be considered, but such would transgress the limits of method set for the thesis in hand. This period is very complex. The most that one can say is that the personal element is present, but is not so easy as usual to demonstrate. It is masked by counter-eurrents, most of which seem the result of the perverse agitations of the Duke of Cloucester.

The actual reign of Henry VI was in reality little more than a protracted minority owing to the extreme weakness of the king. Henry was not an imbecile but in his relations to historical events he might as well have been one. Politically he amounts to almost nothing. His moral character was good, indeed exceptionally so from every standpoint, and his interests in education show that he was no fool. The foundations at Eton and King's College, Cambridge, were the results of genuine royal initiative. But his inability to judge men, his utter reliance on others, and his disinclination for the business of government and the burden of kingship make his position in the intellectual grade-seale of kings a low one. At one time, for a vear or so, his mind entirely gave way, and he was declared legally insane, which malady was in all probability an inheritance from his grandfather, Charles VI of France.

Henry VT is a eharacter worth thinking about. Here is a king who, areording to all accounts and in all liberality, cannot be graded among kings or among male royalty without at least from 70 to 90 per cent of all tabulated persons being given precedence over him for intellectual rating. He would most probably be placeed in grade (3) among the groups collected for "Mental and Moral Heredity in Royalty," possibly in (4) or (2) but not ahove(4). ${ }^{1}$ If he were placed in (1) there would be 70 per cent above him. If he were placed in (2) there would be 92 per eent superior.

The position which Henry VI occupies among actual kings is

1 See pages 19-22 of "Mental and Moral Heredity in Royalty." 1906. 
necessarily even a little worse than this, because the average standard or mean of the kings is higher than the mean of all royalty in the widest sense, as when kings, princes, and dukes of small countries are massed together as they are in the frequency table on page 19 of "Mental and Moral Heredity in Royalty."

If Henry VI were a very intellectual sovereign from the purely theoretical or literary standpoint, and at the same time lacked practical business qualities, like Alfonso $\mathrm{X}$ of Castile for instance, it would be difficult to offset one kind of gift against the other; but there is nothing to show that Henry VI was more than an educated man, interested in furthering the cause of education.

"Lacking resolution and without knowledge of men, he was always under the influence of a stronger mind, and though suspicious, liable to be deceived. In the latter part of his reign he was the puppet of every faction; the kingdom drifted into anarchy and his mind broke down beneath his troubles. Yet Henry was no dullard. Hall is probably right in deseribing him as neither a fool nor very wise. But although he recognized his position as a constitutional sovereign and had some sound political views, his heart was never in business. He was welleducated. His life was that of a scholar and pious recluse. His piety was no mere form and he was devoted to his family." 1 "He ought to have been a monk or a schoolmaster." ?

Except for the period of insanity, the intellectual caliber of Henry VI seems fully equal to that of the average monk or schoolmaster of his day, equal or above the average of all Englishmen of that time. Yet when judged side by side with royalty, he belongs only in a grade somewhere from ten to thirty in a scale of one hundred. Comparisons like this confirm the belief that royalty as a whole is much above the average in natural capacity. ${ }^{3}$ The reign of Henry VI (cir. 1442-1461)

1 T. F. Tout, "Dictionary of National Biography."

2 Oman, "Political History of England," iv, 336.

${ }^{3}$ See p. 257 of Chapter XVII. 
presents no good features that can be recalled. Also there were no great statesmen. Suffolk, Somerset, Warwick, Edmund Beaufort, York, and Margaret of Anjou were not more than politicians or partisans. The history of England at this point is just as disgraceful and no more so than the numerous aecounts of demoralized national life found in other countries when strong leadership happened to be absent.

Edward IV, who defeated the incompetent Lancastrians, and therefore deserves some credit, is not an easy king to grade for intellectual merit. His peeuliar trait was spasmodic energy, his cerebral functioning a patchwork of light and dark. Great gifts as a soldier and all the wily astuteness of a successful diplomat, all the brilliant and popular qualitice, eloquence, wit, goot-humour, and pleasing manners were counterbalanced by periods of extreme lethargy, sensuouness, laziness, and utter indifference to anything save gadlding about and having a good time. Edward IV was a very bright man. He was a better general than Warwick. The medium grade in which he, perforce, is placed, since for much of the time spasmodically his intelleetual activities were much below the average, fails to give a true view. At any rate it makes little difference. The good events of the period were probably not much the direct outcome of the personality of Edward IV. The gains are chiefly on the economic side, - a discernible beginning of manufacture, comparative prosperity among the peasantry, and great artivity in the construction of costly buildings, such as new and improved types of manor-houses, and the large churches in the perpendicular style. Apart from the widespread moral decay (in spite of the churches), which does not come under the scope of the present research, as I have not attempted to study intellectual and spiritual progress, the worst feature appears to be constitutional, - a decline in the power of parliament. The Wars of the Roses make a complex story, especially if causes be sought. They do not appear to have much affected the prosperity of the middle and lower elasses, and the cities were almost entirely removed from the theatre of war. 
Richard III reigned such a short time (1483-1485) that important internal or economic ehanges are seareely worth noticing. His only parliament of 1484 passed one great law restraining a special abuse of royal power.

Richard's successful rival, the first of the Tudor dynasty, a cool, sly, cautious, hard-working king, stamped his impress on the reign in the most unmistakable manner. Henry VII was served by able ministers, Morton, Foxe, etc., but it is not thought that they were ever more than lieutenants placed in power to carry out a perfectly definite and continuous royal poliey, and one for which England on the whole had much to be thankful. The suppression of disorder, the elimination of Lancastrian and Yorkist pretenders, the reburnishing of the crown, gave a problem of more than usual diffieulty at the eommeneement of the reign, and it was not until the reign was half over that the new monarch found himself secure. The last part of Henry VII's reign was very prosperous. A patient, if tortuous, non-belligerent diplomacy secured peace for England between the balanced rivalries of France and the Hapsburgs, and even earned some subsidies. Most important were the commereial treaties which Henry made with Flanders, Seandinavia, Denmark, and Venice. The growth of commeree is the most distinctive eeonomic aspect of the time. The navy also took on some small development. Finances were so well managed that the national coffers fairly burst with the plethora of eoin hoarded by the monarch, an avaricious old fox, an extortionist and despot perhaps, but none the less a benefactor to his country, an undisputed master of a new nation now well ordered and diseiplined and on the highroad to prosperity.

This impetus eontinued under Henry VIII (1509-1547) and England beeame a greater power than ever before, both in native strength and continental influence. Almost every economic and political aspect is "plus" in its trend. The suppression of the monasteries, it is true, caused individual suffering. Educational advance was thereby injured, and its spiritual effects would be hard to weigh; but cconomically this change 
was of advantage to agriculture and to the public revenues. Wool-growing increased especially. The general commercial prosperity found a parallel in the far greater importance of England as a sea power with reliance on the navy. The greater influence over Ireland and incorporation of Wales were part of the larger political rôle which Henry, though always actuated by the most selfish and insatiable ambitions, left as heritage to his nation. Henry VIII was guided in his decisions very little, by opinions or wishes other than his own. There is no proof that any of his ministers or subordinates ever overode him. In the early part of the reign, before the ling was, say, twentythree years old, and took interest only in hunting and in sports, Richard Fox and Wareham, and afterwards Wolsey, controlled the government, but after that Henry grew to be more and more his own master. It is significant that the poriod when Henry and Wolsey worked together $(1514-1529)$ was not crowned by diplomatic successes. Nor was Thomas Cromwell ever anything more than a very officient agent in earrying out policies originating in the mind of the ling. "Henry's unique position among English lings is owing to the extrandinary degree of personal weight that he was able to throw into the government of the realm. Strictly speaking he was not an unconstitutional sovereign; all his doings were elothed with the form of legality. But the whole machinery of state, both legislative and executive moved simply in accordinee with his pleasure, and however unpopular might be his government at home or hispoliey abroad, no one could venture to impugn his acts or could doubt his consummate stat esmanship." 1

"The inerease of English influence abroad during this reign was in fact due rather to the personal qualities of the king and to the skilful use which he made of European complications than to the number or excellence of the troops at his command." 2

"He worked for the good of the state because he thought his interests were bound up with those of the nation, and it was the

\footnotetext{
1 J. Gairdner in "Dictionary of National Biography."

2 "Cambridge Modern History," ii, 473.
} 
real coincidence of this private and public point of view that made it possible for so selfish a man to achieve so much for his country." I

The reign of his successor gives another proof of the personal weight of Henry VIII in the political and economic disruption which followed his death. "England altogether fell from the great European position which she held under Henry." 2 Agrarian discontents, financial exhaustion, and politieal mistakes are the chief features which mark the minority of Edward VI. "It is elear that England must soon have risen against the misrule of the Protectorate if the Protectorate had not fallen by the intestine divisions of the plunderers themselves." 3 England also declined during the reign of Mary (1553-1558). "Never had the fortunes of England sunk to a lower ebb than at the moment when Elizabeth mounted the throne. The country was humiliated by defeat and brought to the verge of rebellion by the bloodshed and misgovernment of Mary's reign. . . France, mistress of Calais, beeame mistress of the Channel, .. Scotland a standing danger in the north. ... In the presence of this host of dangers the country lay helpless without an army or fleet, or the means of manning one, for the treasury, already drained by the waste of Edward's reign, had been utterly exhausted by Mary's restoration of the Church lands in possession of the Crown and by the cost of her war with France." 4

Mary was herself an inefficient ruler, though she did not lack mentality. On the contrary, her preeoeiousness as a ehild was remarkable, but the high spirit, courage, and mental activity could not make heaclway against a pathological constitution, and growing bodily infirmities beeame accompanied by a disordered mind. The infamous persecutions of her reign have gained her the name of Bloody Queen Mary, though quite unjustly, for the troubles, religious as well as politieal, lay in a too great reliance on others; her own nature would have shrunk from barbarities in every form. Mary, though not dull, lacked

1 A. F. Pollard, article HIenry VIII, Encyclopædia Britannica, 11th edition.

2 E. A. Frecman.

${ }^{3}$ J. R. Green.

4 Green, pp. 731, 732. 
judgment. Her reign was certainly a period of decline. Whatever one may think of the general causes responsible for the state of England lluring the years 1553-1558, the point remains incontestable that eren as late as the sixteenth century and in England, a wretched and deplorable reign is to be found which seems to reflent the lack of royal leadership. Mary's reign and the reign of Edward VI point back to the first two Tudor periods, and indicate by their contrast the reality of the greatness of the work of Henry VII and Henry VIII. Mary's reign is also interesting as the last in English history during which decline outwrighs adriner.

Elizabuth had far more influence than her aldor sister over the affairs of her nation. Without preteneling to estimate minutely the part she played in an age male glorious by so many forms of activity, one "an at least remark that her era presents the parallelism and identity of sorereign and politicocoonomic variation, the listing and counting of which is the chice burden of this thesis.

It would seem unwise to hazard an opinion as to whether England would or would not have progressed at this time under a weak monarch. It is, however, no assmption but rather a conclusion, both from intensive study of the reign itself and from the generalization eoncerning strong monarchs, that the personal impetus from Elizaheth herself addeel to the national momentum. The personal influence of the ruler is much more difficult to quantitate here than in most history, and is interwoven with a widespread evolution of the entire English race.

From James I to George III (1603-1811) no great sovereign, with the exception of William III, sat upon the throne of England, yet not a single reign-period ean be adjurlged other than progressive. The royal factor becomes so reduced that it is sufficient to pass rery rapilly over this entire era. The main requirement is to point out that it is an age of non-royal growth and is moreover very long in duration, and, comparatively speaking, very early in the date of its beginning. Nothing is 
comparable to it in European history except the same age in Scotland.

The first two Stuarts cannot be thought to have contributed much to England's progress, yet theirs was a time of great commercial activity, of voyages and discoveries, of conquests abroad, and a new life within the British Isles. It was particularly an era of colonial expansion, growth in manufactures, inerease in population and in wealth, improvement in agriculture and activity in building, - essentially an economic prosperity. The condition of the lower classos remained perhaps the same, the eivil wars naturally brought much distress, but the success of the popular cause, and above all the stanch and determined resistance of parliament against the impositions of tyranny make the reigns of James I and Charles I of important moment in political growth. It is only in diplomatic work and in the bellicose potentialities on which diplomacy leans that weakness looms in the balance.

Cromwell's personality overcame these conditions. The navy became vastly improved, and England could be again aggressive. The period of the Commonwealth was, both politically and economically, a glorious one. If Cromwell was not a king, and so properly has no place in this study, there is this to be said, that he behaved like a king, and his single authority became supreme. He was, all in all, the same as many founders of royal dyuasties, and if his son Richard had been made of the stuff of his father, perhaps a Cromwellian line might have eome to the throne of England. The birth and public appearance of men like Cromwell from the ranks of the commoners gives the philosophically inclined one kind of measurement of a nation's power of development independent of royal leadership, - a phenomenon, as I have often remarked, rare for long periods of time in many parts of Europe.

Charles II was of little use to his country, yet his reign was marked by most important constitutional advance. The government was utterly incapable and its foreign policy shameful, yet the House of Commons marched forward as never before. 
It was a wonderfully broad movement and, comparatively speaking, uninitiated by any very famous statesman. Agricultural conditions and the wool trade were not so progressive, but a trade in silk grew to respectable dimensions. Commercial and financial interests made continued strides. Much the same may be said of James II and his reign. At the close of the struggle between parliament and the crown it became settled that England was ever afterwards to be ruled by a constitutional king. Yet it cannot be asserted that the good government which England afterwards enjoyed, came about because of this legal development and long training in the art of self-government. The having of many voices representative of the entire nation can scarcely suffice to explain why the Anglo-Saxon has ever been an outrider in the march of modern democracy and the preceptor of popular liberty. The causes must lie deeper than this. For if early training in representative government were a cause worthy of being spoken of as the cause, it ought to find a general support in the relations of constitutionalism to successful government in other parts of the world, a question which I have discussed at the close of the chapter on Spain.

Thus William III came to the throne as a constitutional king. He was the last English king to whom one applies the mystic word genius. Whatever his shortcomings may have been, and they were frankly numerous, there is something in the majesty of William III, in the breadth of his grasp, in the unconquerable heroism of his nature, and insight into the destiny of nations, gifts of leadership and of prophecy, that make the frail little eagle-beaked figure irresistible. The impression in the end is always the same, that it was William III who held Europe together in the struggle which delimited the greed of Louis XIV and the overgrowth of France. William III was one of the greatest diplomats of modern times. Here his influence is undoubted; but much of the successful side of this reign, the naval victories, progress, - legislative, financial, industrial, and commercial, - can scarcely be credited to the king. 
England continued to expand under Queen Anne, a sovereign of the dullest type. The foreign policy and continental wars were brilliantly successful. Blenheim Oudenarde and Malplaquet brought both profit and inspiration. By the Peace of Utrecht the objects at which England had aimed at the outset of the war were attained. Her trading interests were secured and extended; she obtained Newfoundland, Nova Scotia, and Hudson's Bay Territory in America, and Gibraltar and Minorca in Europe. France was humbled and England's future was laid bare. The great man of the hour, Marlborough, must receive at least a mention, though no pretence be made to estimate the personal note.

So under the Georges, throughout the eighteenth century, the advance continued, slow at first, faster as it grew, cumulative, and, on the whole, unprecedented both in length of time and magnitude. The twenty years of peace from 1719 to 1739 were utilized by the people in a development, material and mundane, it must be confessed, yet it was this economic strength which aided the greater political expansion and militant renown, "The Empire on which the sun never sets." The closing quarter of the eighteenth century saw in England the greatest activity of industrial forces that had ever been witnessed in the history of the world. Notable progress in agriculture followed the new science of cultivation, the rotation of crops. Cattle breeding became important as the science of that art brought greater results. It was the beginning of the age of iron and of coal. The flying shuttle, the jenny, the mule, and the steam-engine gave England a pioneer leadership in that form of evolutionary civilization which was so particularly to characterize the nineteenth century. Great statesmen and great scientists there were in plenty, but the Hanoverian kings sink into nothingness, so great is the country and so little are they, soulless and uninspiring, scarcely emerging at all into the really interesting happenings of the time or aiding in the great constructive efforts. George III was scarcely the nonentity that he has been sometimes pictured; for his portraits, more than those 
of most kings, have been darkened and blurred by party prejudice. He was better than the first two of his name, but the best we can read of him still leaves us cold and unmoved. No, we cannot get more than the feeling that George III was a prig, a man great in little things and little in great. The names of Walpole, Chatham, Burke, Fox, and Pitt stand in the world's Hall of Fame unquestioned. Criticise and dissect as we may, the fact remains that there have not been greater non-royal statesmen thin these. If there have been, then who are they? After one or two great statesmen are picked from Greece and Rome, and three or four from modern times, my point will be proved, for the above five English luminaries of the eighteenth century will still be in the first score, and in this sense, twenty is a small number. ${ }^{1}$ The almost synchronous appearance of four or five of that never numerous species, the great statesman, is a factor to be reckoned with, no matter what may be the elements of England's remarkable political and eeonomic advance.

Some of us who believe that, after all, the real differences among nations, as among the individuals who compose them, are caused by arrangements of chromosomes within the gametes, will look upon these great statesmen as born and not made, and will also believe that the nation as a whole was much favoured by certain forces almost hidden and unsuspected as yet, forces inborn in their nature, such as may well be acting all the time without easy detection, - differences brought about by natural selection, by immigration and emigration, by differences in net fertility, sexual selection, the formation and development of the easte system, and other eugenic or aristogenic movements but little understood.

1 The general impression which I have followed in writing the above paragraph finds an interesting support in the objectively compiled list of eminent men published by J. MeK. Cattell in Popular Science Monthly, vol. lxii, p. 363. The order here is Burke, Pitt, Fox, Pitt [presumably the younger], and Walpole. The first four are, according to this test, evidently worthy of "the highest grade." Burke is number twelve and Pitt (probably Chatham, though the author does not state) is number eighteen in the list, even when all nations and all forms of human aetivity are included in the competition. 
However that may be, my purpose in this chapter has been to show that by carefully measuring one single force (namely, the royal influence in England) I have been able to establish and definitely mark out a difference, a something to be compared and contrasted with other European nations. As I have said before, the personal influence of the sovereign was very strong in England prior to the time of Elizabeth, though there are to be found a number of milestones marking the rather spasmodic growth of democratic evolution earlier than this, and even earlier than John. Those interested in either defending or explaining the anti-aristocratic doctrinaire will do well to concentrate upon these peculiar early periods; above all they must satisfactorily explain the wonderfully continuous budding forth which commenced with the Elizabethan era. But they must not fail to take into the reckoning the regal and individual equation, the exposition of which has been alone the object of this chapter. 


\section{CHAPTER XVII}

\section{INTERPRETATION OF THE RESULTS}

Harisg viewed the undulating waves of economic and political prosperity in detail, it now behooves us to leave the microscopic method for the macroscopic and to take a broad survey of the whole matter. Standing back at a distance, the main outlines are still clearly enough visible, - the rise and decline of Spain and Portugal, Sweden and Turkey, the cumulative but spasmodic growth of France, the early slow, and late accelerating, growth of Prussia and Russia, the evanescent importance of the Dutch, the retarded development of Scotland, the comparative negativeness of Austria, the unexpanded state of Denmark, and the early hesitating but afterwards continuous progress of England; these all present themselves cn masse in bold relief. Anel with these variations are the concomitant variations in the intellectual strength of the monarehs themselves. Some correlation is evident. How much that correlation is, beeomes the first question. The cause of the correlation is the second.

The following table shows numerically the correlations (as derived from the tabulation in the Appendix) between the three grades for conditions and the three grarles for rulers. At the bottom are the totals for all countries, and these figures are the basis for the general correlation approximately obtained. The figure eight in the upper line for France means that there were eight cases where the ruler was "plus" at the same time that the conditions were "plus." Next to the right the four means that four instances occurred in France when a "plus" ruler was associated with medium conditions. There were no cases in France when a "plus" ruler was associated with "minus" or declining conditons. 
TABLE I

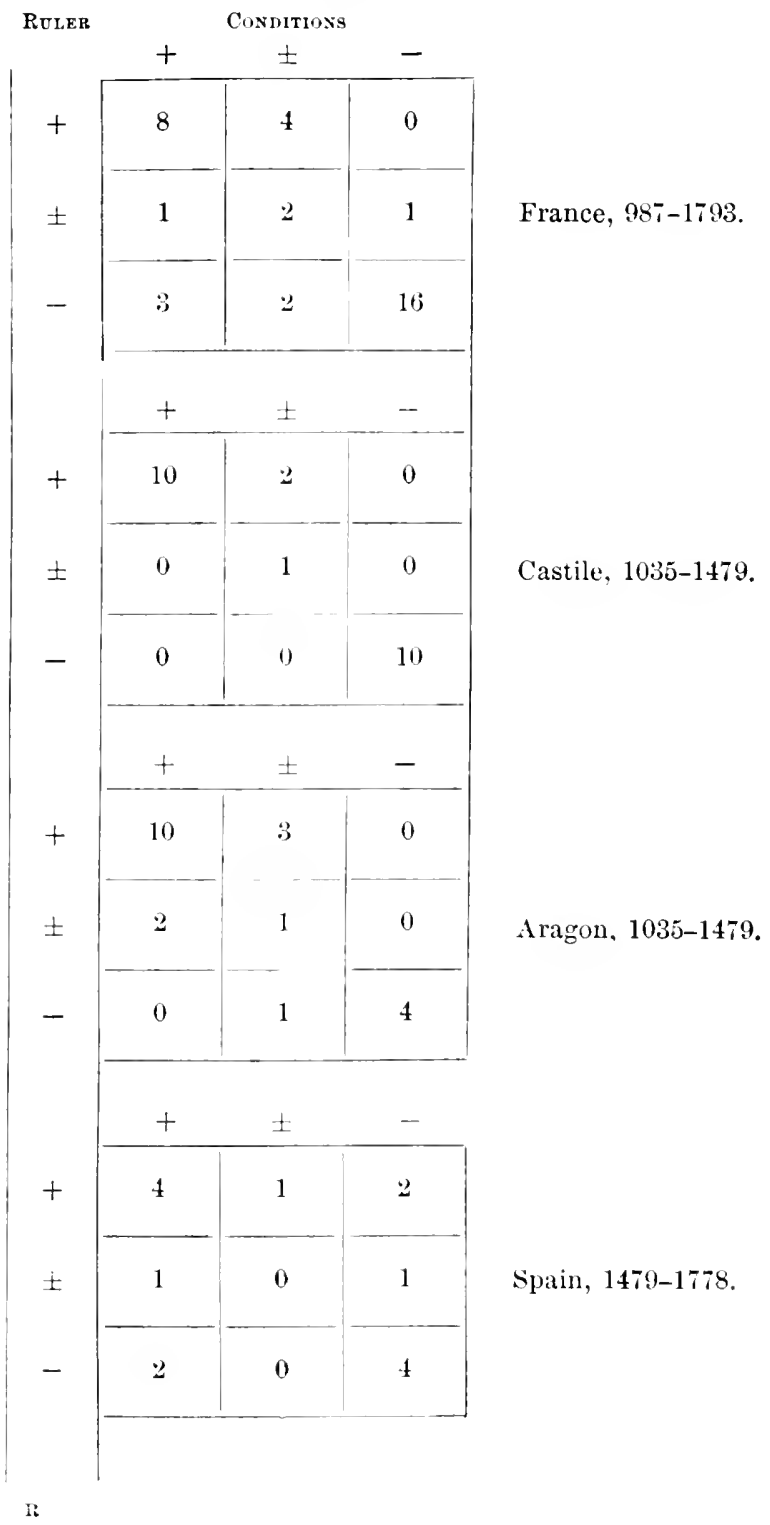




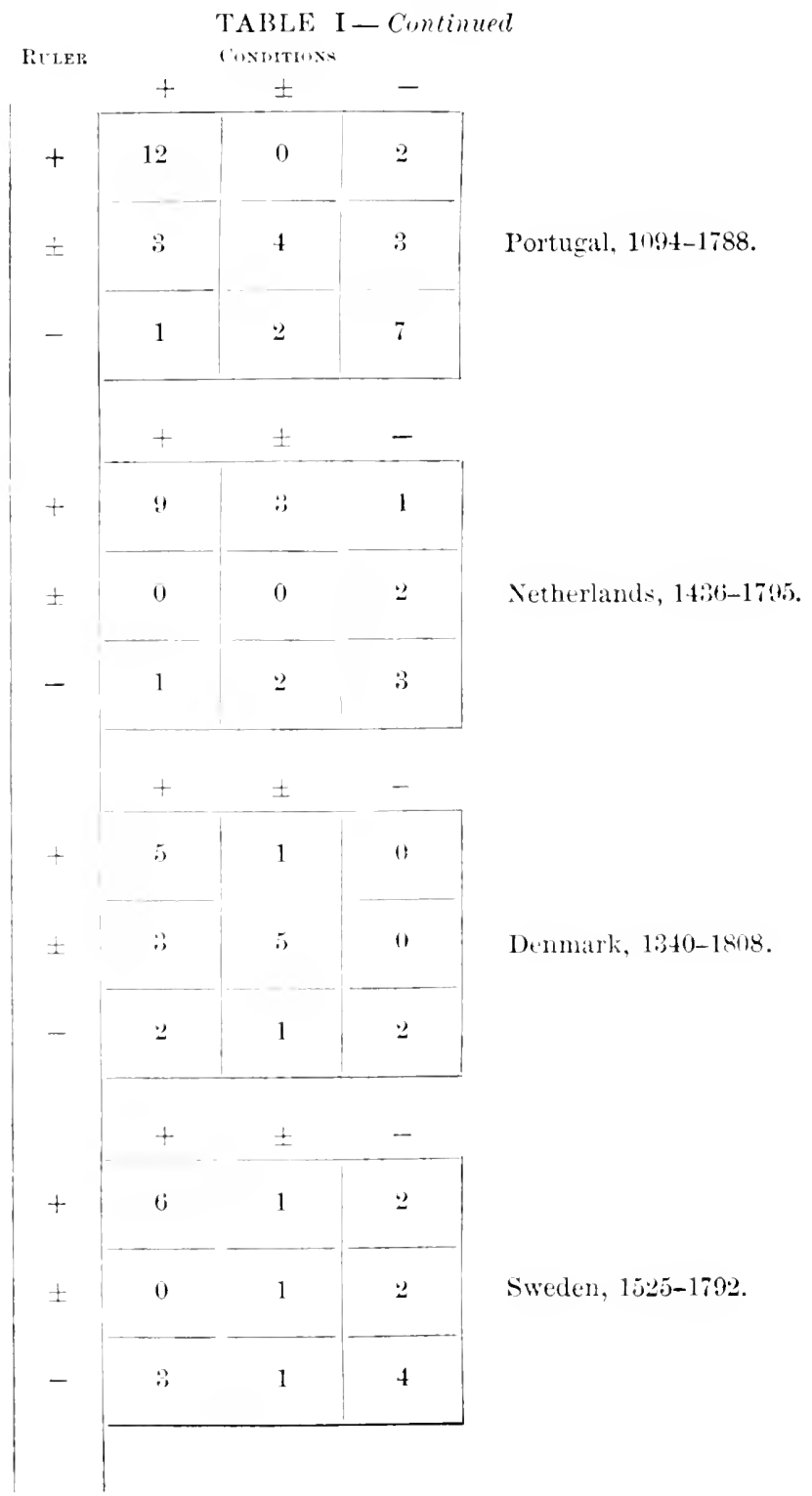


INTERPRETATION OF THE RESULTS

TABLE I- Continued

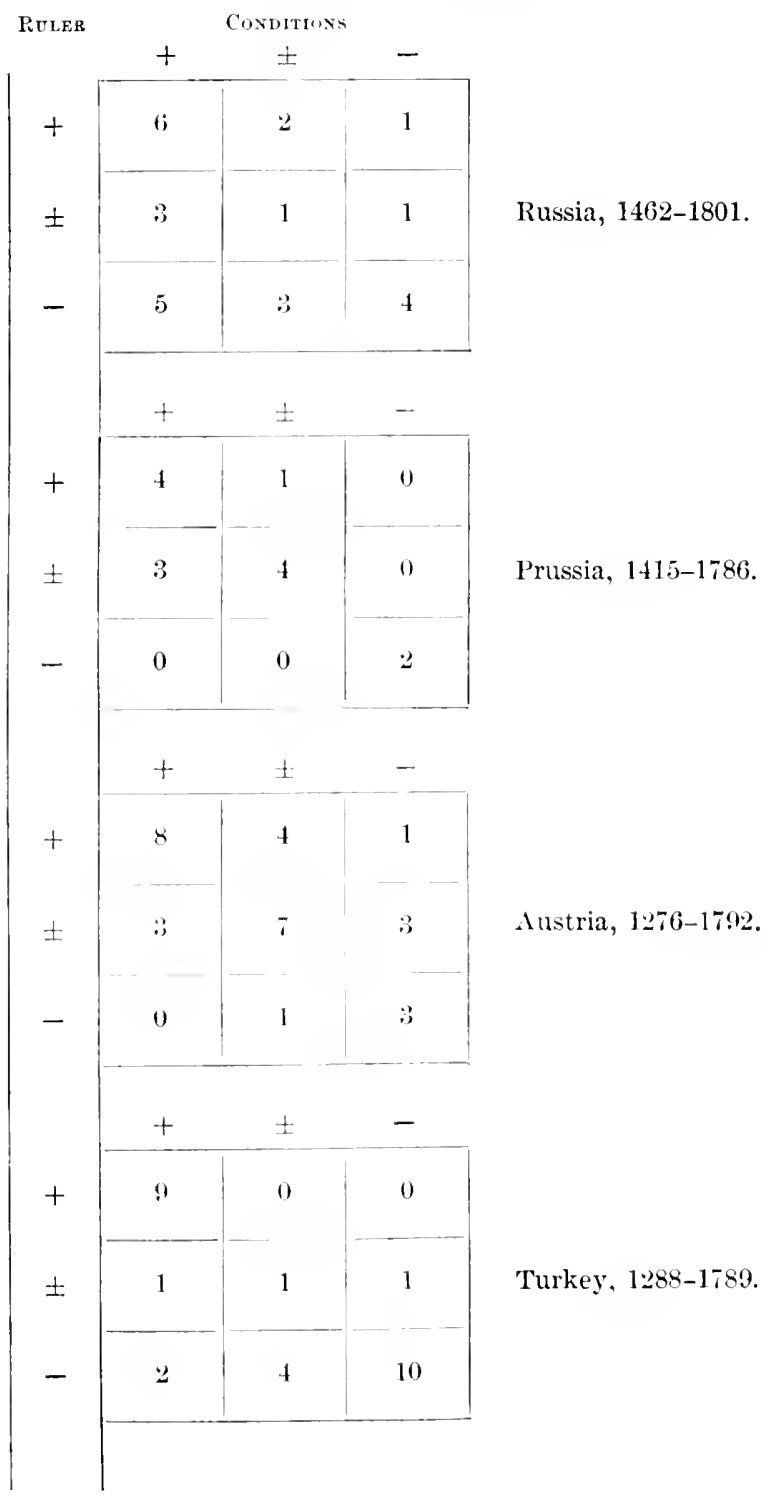




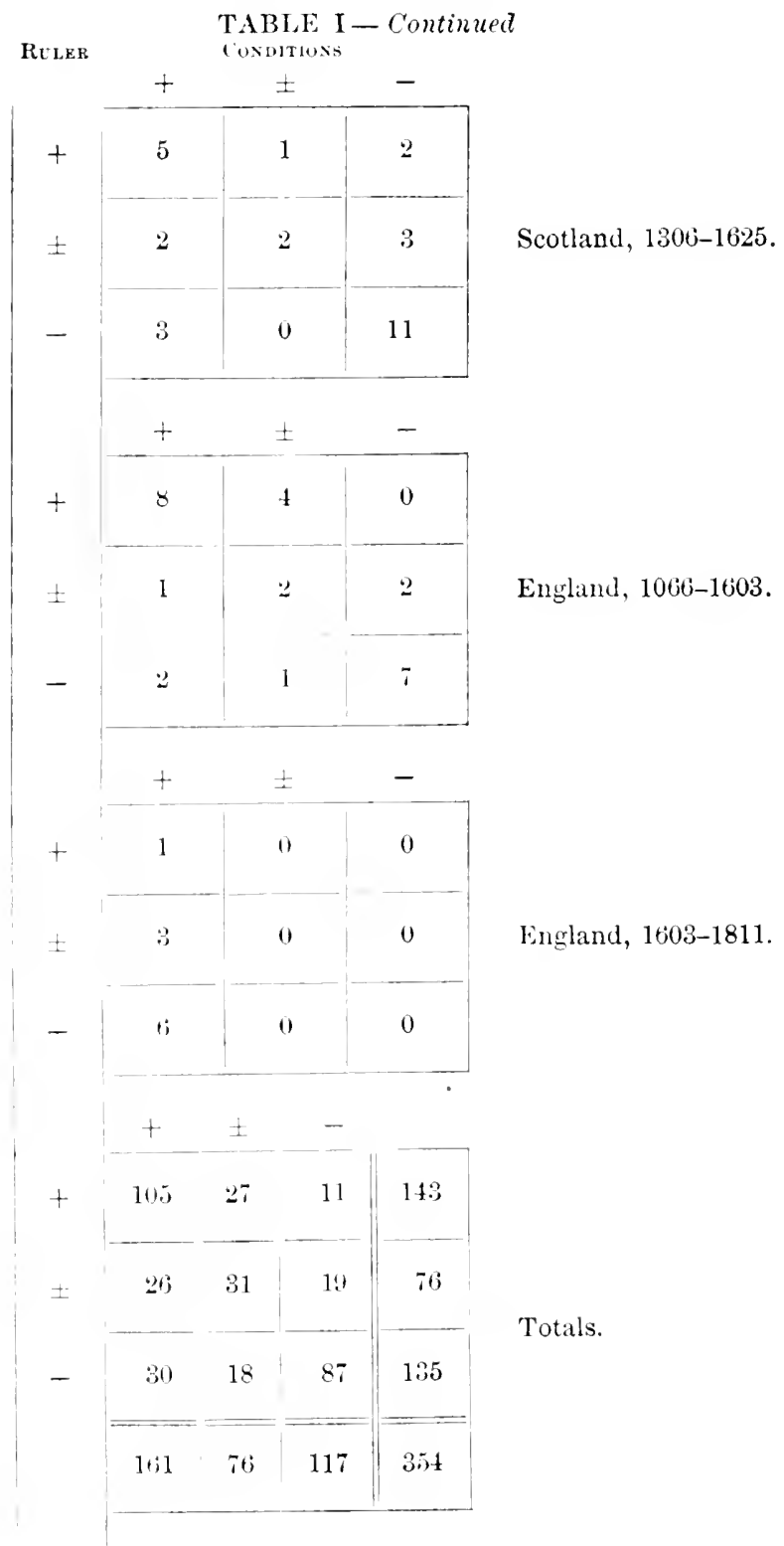


All taken together the totals show one hundred and five instances of a superior ruler associated with advancing conditions against eleven associated with decline. The true numbers are probably less than eleven and greater than one hundred and five, as I have thrown all the doubtful cases (all those with two signs) into squares which are least close to representing identity. Thus if the ruler were + and the conditions ( \pm or - ), it has been counted as one case of ruler "plus," conditions "minus," and so for each case on the border line of doubt.

The figures for each country separately are too small for mathematical treatment; but they are not too small for a uniform result. With the exception of modern England, all show an unmistakable correlation. An idea of this is gained by comparing the greater weights of the numbers in the upper right and lower left hand squares (multiplied together) with those in the upper left and lower right (multiplied together). If there were no correlation $(r=0)$, the products would balance each other. If the correlations were perfect $(r=1.00)$, all the numbers would fall in the upper left, the centre and the lower right squares. The amount of deviation from this $(r=1.00)$ is measurable and, in this research, for the total, is about $r=.60$ to .70 with a probable error of about .05 . I have not given more than an approximate value to $r$, but I feel secure in placing it at $r=.60$ for the lowest limit of its value. This, it must be remembered, is a very high correlation in comparison with the general run of anthropometric and biological results.

The correlation coefficient must not be confused with a percentage. As a matter of percentage, it is possible to express the results in the table for totals thus: out of 354 cases, 41 or less than 12 per cent show conflict, 223 or more than 63 per cent show identity, and 25 per cent divide this significance. If the cases with the double sign $( \pm$ or + , etc.) are halved and one half allotted to increasing the percentage of identity, then 70 per cent of the cases would show identity of signs, and less than 10 per cent show conflict, while the remainder would 
divide their significance. A summarized statement of the results, in terms of percentages, would be: strong, mediocre, and weak monarchs are associated with strong, mediocre, and weak periods respectively in about 70 per cent of the cases. Strong monarchs are associated with weak periods, and weak monarchs (inclutling non-royal regents) with strong periods in about 10 per cent of the eases. In about 20 per cent of the cases mediocre monarchs are associated with strong or with weak periods, or mediocre periods are associated with strong or with weak monarchs.

To return to the correlation coefficient and its significance. The reader will now see that the coeffieient of correlation is obviously more convenient than pereentages as it expresses in a single fraction all that ran be put into an unwieldy paragraph. Other correlations ean in the future be worked out and compared with it, as, for eximple, the correlations between politico-economic conditions on the one hand, and on the other, a number of likely concomitant variables, - the personalities of prime-ministers, the condition of war or peace, intellectual, religious, or artistic activity, adventitious opportunities such as changes in the great trade routes, climatic rhanges, forms of govermment, and amount of liberty, or any other series of changes which by hypothesis may be thouglit correlated.

As stated above, a correlation of $r=.60 \mathrm{is}$ a high one, in comparison with most correlations. It is greater than that expressing the mental and bodily resemblances between children of the same parentage. The corrclation coeffieient for brothers is not over $r=.50$; for parents and offspring it is about .40; for a man's strength of pull and stature, .22 to .30 ; for strength of pull and weight, .34 to $.54 .^{1}$ Some correlations are much higher, as, for instance, those representing the resemblances between twins, where the correlations approximate .80 , and are often .90 or more. ${ }^{2}$ Such high correlation ratios as

1 K. Pearson, "Grammar of Science," London, 1900.

2 E. L. Thorndike, "Measurements of Twins," New York (Science Press), 1905 . 
these represent that sort of resemblance between twins which, to the casual observer, seems like identity, and leads to all those amusing mistakes and confusions, anecdotes of which every one recalls.

So, if I had found a correlation between rulers and conditions running as high as .80 or .90 , it would be about the same as complete parallelism. Having found a substantial, indeed a very high, correlation ( $r=.60$ or more) between mentalities of rulers and the conditions of their realms, the next step is to inquire the causes of this phenomenon. It may be that the monarehs have influenced the conditions; it may be that the conditions have influeneed the monarehs; or both may be caused by some third external agency; or any combination of the three hypotheses is tenable.

Let us first see if it is possible to find any evidence that conditions have influenced monarchs. Has any country ever moulded its rulers according to a type? The early history of Turkey would seem to support such a view, or at least it presents a coördination of facts, a repetition of erents, formed in the sort of way one might expect if general or external conditions were forceful enough to make themselves measurable. There are seven strong Sultans, one after another, in the Ottoman dynasty from $128 S$ to 1481 . A mediocre Sultan comes next, and two more very high in mental grade extend the chain as far as the year 1566 . Is it not unlikely that such a line of strong Sultans should be eaused by the forces which we eall "heredity" (i.e. predetermined in the germ-plism)? A wonderful pedigree on the maternal side would make such an heredity expected, but this cannot be elaimed. The mothers of the Sultans were, with one exception, the daughters of undistinguished ancestors. On the other hand, reasons can be easily imagined why the Ottoman power should have expanded as a result of general causes. Therefore, the study of this country by itself, and during this epoch, would undoubtedly induce any historian to a conviction favourable to the foree of events, rather than a belief in the power of individuals. Here is a good illustration 
of the danger of drawing generalizations from limited historical perspective.

If any one country is chosen at random, a series of repetitions of practically ten progressive periods is not to be expected unless the pedigrees are very strong, but on the contrary one such curious repetition of "plus" periods is to be expected from the laws of chance, if a large number of countries and periods is made the subject of study. That is, we may rightly conclude that for once the strong qualities passed directly down the male line from father to son for many generations without diminution or loss. "Heredity in Royalty" shows that practically all the other families that continued to reproduce genius did so only when selection of similar strains, on the maternal side, supported the male line. The strength of the Turkish reigning line was somewhat maintained by struggles between the brothers, but even setting this aside, there is nothing in the single instance of ancient Turkey to refute the general position which I maintain, provided it is the only instance. Looking over the tabulations, one sees that ancient Turkey is the only example of such extensive repetition, and therefore no argument can be drawn from it in support of the view that long-acting eircumstances have influenced monarchs.

Modern England furnishes the only other example of a long unbroken series of "plus" periods, but here the monarchs are not "plus" and the history of England, from the age of Elizabeth onward, has been constantly granted as not belonging to or resembling the major portion of the history which the present volume discusses. Next in number of repetitions of "plus" reigns Sweden counts five, but the total periods covered is only from 1600-1660. There are but two instances of a whole century covered by continuously progressive reigns, in Aragon from 1035-1134 (three reigns), and again in Aragon from 12281327 (four reigns). The other case of as many as four progressive reigns coming together is found in the Netherlands from $1507-1559$. 
Table II ${ }^{1}$ proves that no analysis of the whole series of signs can be made so that cycles of prosperity and adversity can be demonstrated. Such cycles if present would doubtless be an argument in favour of surroundings as against personality, and the absence of such cycles is an argument in favour of personalities. The run of signs is, with the exception of modern England, nothing more than a chance or random distribution. There is no tendency for the same signs to be grouped into series. At least the tendency is not strong enough to be measurable in the data here presented. The whole series departs so little from a random arrangement that nothing can be predicted from one symbol as to the character of the next. In other words, the conditions of one reign do not sensibly influence the conditions of the next, nor is there any evidence that several reigns (say three) are, as a whole, so much influenced by any general or continuous force that they are moulded to a common resemblance. Nor is there any evidence of small waves of gradual rise and fall as would be expressed by - followed by \pm followed by + or the series,,,,,,+ \pm+ \pm- \pm+ .

Table II shows twenty-eight eases where + is preceded by + and also followed by + . There are eight cases where + is followed by + and preceled by \pm . There are nine cases where + is followed by + and preceded by - . This last is a type of sequence showing a sudden jump from - to + . The first shows no change, the sccond but slight change. The types showing an abrupt change are numbered III, VI, VII, VIII, IX, XIX, XX, XXI, XXII, XXV. The average of these is 12.8 cases showing abrupt change. The average of all the other cases (those showing gradation or similarity in the signs) is 11.3. This is somewhat artifieially lowered by the greater total number of \pm signs in this group. If all those cases between $\mathrm{X}$ and XVIII are omitted, we eliminate this error, but the average of the transitional cases is not much raised. The number of gradual changes then averages 13.4. It can be seen that number IX shows twenty cases of progressive reigns sand-

'Compiled by treating all the "conditions" signs as if they formed a string. 
wiched between two periods of decline; number XIX shows fifteen cases of the reverse. Thus both the types which illustrate the most abrupt changes are equal to and even in excess TABLE II

\begin{tabular}{|c|c|c|c|c|}
\hline & NTYMBER OF CISEA & \multicolumn{3}{|c|}{$\therefore$ FUCENCE } \\
\hline I & 28 & + & + & + \\
\hline II & 8 & \pm & t & + \\
\hline * III & 9 & - & + & + \\
\hline IV & 16 & + & + & \pm \\
\hline $\mathrm{V}$ & 10 & \pm & + & \pm \\
\hline * VI & 9 & - & + & \pm \\
\hline * VII & 13 & + & + & - \\
\hline * VIII & 8 & \pm & + & - \\
\hline * IX & 20 & - & + & - \\
\hline $\mathrm{X}$ & 12 & + & \pm & \pm \\
\hline XI & 9 & \pm & \pm & + \\
\hline XII & 3 & - & \pm & + \\
\hline XIII & 13 & + & \pm & \pm \\
\hline XIV & 11 & \pm & \pm & \pm \\
\hline $\mathrm{AV}$ & 8 & - & \pm & \pm \\
\hline XVI & 12 & t & \pm & - \\
\hline XVII & 8 & \pm & \pm & - \\
\hline XVIII & !" & - & \pm & - \\
\hline * XIX & 15 & + & - & + \\
\hline$* \mathrm{NX}$ & 11 & \pm & - & + \\
\hline * XXI & 19 & - & - & + \\
\hline * Xxil & 10 & + & - & \pm \\
\hline XXIII & 3 & \pm & - & \pm \\
\hline XXIV & 8 & - & - & \pm \\
\hline * XXV & 14 & + & - & - \\
\hline XXVI & 17 & \pm & - & - \\
\hline Xxvil & 17 & - & - & - \\
\hline
\end{tabular}

* These are instances showing abrupt changes.

of random expectation. These figures twenty and fifteen may be matched against the figures seventeen and twenty-eight at the bottom and top of the lists. The numbers of cases are all 
about of equal significance. The,,+++ combination occurs a few more times than any of the others, but would not present such excessive repetition except for the exceptional series in the late history of England.

There should be a slight correlation between the signs and their neighbouring signs, as a result of the action of heredity moulding successive rulers towards the same type of ability. The introduction of minorities and the starting of new dynastic lines tend to lower this correlation, but even so I should expect a correlation ratio of about $r=.10$ to .15 . This ratio being small could not be measured without a far greater number of cases. The total 354 is large enough to measure a high correlation like that between monarchs and the condition of their countries ( $r=.60$ or more), but is not great enough to measure a low correlation like that which probably exists between one reign and the next. It is, however, a total of sufficient magnitude to prove that the correlation is not large between the conditions in one reign and the next. A high correlation would certainly have been detected even with the small total of 354 . The material which I have collected is sufficiently extensive to give an answer to this particular question and to prove that there is no great tendency for periods of prosperity to be clustered in groups.

Thus to recapitulate: The first reason for believing that the conditions have not caused the variations in the monarchs themselves to any considerable extent, is drawn from both an intensive and extensive examination of the transitional periods between the clifferent states of progress. These transitions are indicated whenever the symbols for conditions of the country change; especially when they change from + to - , or from to + . If these usually merged into each other through the gradual transition of an intervening sign (which is $t$ ), we should naturally explain the gratual change not as a personal but as a general force. On the contrary, if there are many cases of abrupt change occurring on the death of one king and the accession of another, then there is that much in favour of the 
hypothesis of personal influence. An examination of the whole material demonstrates a great number of abrupt changes in the signs; and moreover it may be added that a detailed reading of the actual histories dealing with these times of transitions shows numerous examples of direct statements of the abruptness of these changes, the whole taking place in a short time.

A second argument in favour of monarchial influence is drawn from minorities and interreigns. Here we have several known and admitted facts to start with. The fact that it was a minority or interregnum is known, and if no member of the royal family is in control as regent, this fact is also known. This furnishes a case of "monarch minus" that may be accepted with certainty. These sure cases of "monarch minus" can then be compared with cases of "monarchs minus" presumably, based on the opinions of history. If the advance in prosperity were due to propitious circumstances, why did not the countries advance during minorities? They did during some minorities, when under the control of some one strong leader who was virtually a monarch and acted like a monarch.

Table III shows thirty-six minorities or interreigns that were "minus" or retrograding in their conditions (beginning at the top the minorities of John II, Charles VI, of France, etc.). Twenty-nine of these were either under weak regents or were governed by councils with divided power. Twenty-one of the divided regencies turned out disastrously. The right-hand column shows but two divided regencies associated with "plus" conditions. The whole series of facts and statements concerning both the disastrous and propitious conditions during minorities is understandable enough on a basis of "monarch causing conditions," but is not understandable on the reverse view. 
TABLE III

Regencies, Minorities, And Interreigns

“Divided" = power divided in a council

\begin{tabular}{|c|c|c|c|}
\hline & $\begin{array}{l}\text { "Minus" on Dechining } \\
\text { Conditions }\end{array}$ & $\begin{array}{l} \pm \text { "Plus or Minus" or } \\
\text { DoubtFul Conditions }\end{array}$ & $\begin{array}{l}+ \text { "Plus" or Progres- } \\
\text { sive Conditions }\end{array}$ \\
\hline & $\begin{array}{l}\text { Charles V, -, for } \\
\text { John II } \\
\text { Divided, for } \\
\text { Charles VI } \\
\text { Divided, for } \\
\text { Francis II } \\
\text { Marie de Medici, -, } \\
\text { for Louis XIII } \\
\text { De Luynes (non- } \\
\text { royal), -, for } \\
\text { Louis XIII } \\
\text { Duke of Bourbon,-, } \\
\text { for Louis XV }\end{array}$ & $\begin{array}{l}\text { Catherine de' Medici, } \\
+ \text {, for Francis II } \\
\text { Anne of Austria, } \pm \text {, } \\
\text { for Louis XIV } \\
\text { Philip of Orleans, }+, \\
\text { for Louis XV }\end{array}$ & $\begin{array}{l}\text { Baldwin, +, for } \\
\text { Philip I } \\
\text { Blanche, +, for } \\
\text { Louis IX } \\
\text { Anne, +, for } \\
\text { Charles VIII } \\
\text { Card. Fleury (non- } \\
\text { royal), for } \\
\text { Louis XV }\end{array}$ \\
\hline 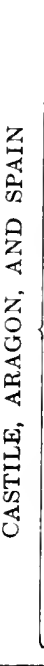 & $\begin{array}{l}\text { Divided, for } \\
\text { Alfonso VIII } \\
\text { De Lara (non-royal), } \\
\text { for Henry I } \\
\text { Divided, for } \\
\text { Alfonso XI } \\
\text { Divided, for } \\
\text { Henry III } \\
\text { Divided, for } \\
\text { John II } \\
\text { Marie Anne, -, for } \\
\text { Philip IV } \\
\text { Divided, for } \\
\text { James I } \\
\text { Divided, Interregnum } \\
\text { before Ferdinand I }\end{array}$ & $\begin{array}{l}\text { Ximenes (non- } \\
\text { royal), for Joanna }\end{array}$ & $\begin{array}{l}\text { Maria, }+, \text { for } \\
\text { Ferdinand IV } \\
\text { Ferdinand I of } \\
\text { Aragon, }+ \text {, for } \\
\text { John II of Castile }\end{array}$ \\
\hline
\end{tabular}


TABLE III - Continued - "Minus" or Declinixg
Conditions

( Mar, - for

David II

Dougras and Moray, for Daris Il

Murdock, - for Jamies I

5

$\frac{6}{3}$

Divided, for

Jalnex II

Dividere for James 111

Divided, for James I

Arran, - , for Mary

Dividod, for Jalmes li 士 "Ples or Minua" or + "Ples" or Progres-
Dorbtrle Conditons

Robret situart, \pm , for Mory, - for

Dalid Il

Datid II

Allany, + for daunes 1

Lenuedy, +, for Jalmos 111

Morton (nonroyal), for Janes VI
( Maximilian, t. for Philip tle. Ilatudsome

Divided, for Philip II I)

㬅

Mlva, for Philip I I l)

Requesens, for Philip 11 (I)

The States, $1702-1747$

Anne, \pm for

William $V^{\circ}$

The States, $1759-1766$
Maximilian, +, for Clatrles I

The statrs, 16.j0-16.2:
Marearet of Sarves, T. for Charles V

Mary, + , for Charles 1

Emmanacl Philibert. T, for Philip II 
TABLE III - Continued

\begin{tabular}{|c|c|c|c|}
\hline \multicolumn{2}{|r|}{$\begin{array}{c}\text { - "Minus" or Dechiving } \\
\text { Conditions }\end{array}$} & $\begin{array}{l} \pm \text { "Ples oR Mines" oR } \\
\text { DoubtFel Conditions }\end{array}$ & $\begin{array}{l}+ \text { "Plts" or Progres- } \\
\text { sive Conditions }\end{array}$ \\
\hline 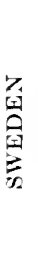 & $\begin{array}{l}\text { Divided, Interregnum } \\
\text { before Christian III } \\
\text { Divided, Charles IX } \\
\text { and Sigismund } \\
\text { Divided, for } \\
\text { Charles XII }\end{array}$ & $\begin{array}{l}\text { Divided, for } \\
\text { Charles XI }\end{array}$ & $\begin{array}{l}\text { Margaret, }+ \text {, for } \\
\text { Eric } \\
\text { Divided, for } \\
\text { Christian IV } \\
\text { Oxenstjerna, for } \\
\text { Christina }\end{array}$ \\
\hline 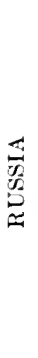 & $\begin{array}{l}\text { Divided, for } \\
\text { Ivan IV } \\
\text { Divided, for } \\
\text { Feodor II } \\
\text { Divided, Interregnum } \\
1610-1613 \\
\text { Sophia, +, for } \\
\text { Peter the Great }\end{array}$ & $\begin{array}{l}\text { Helen Glinska, } \pm \text {, } \\
\text { Iran IV } \\
\text { Boris Morosoff, for } \\
\text { Alexis } \\
\text { Divided, for } \\
\text { Peter II } \\
\text { Anne, - for } \\
\text { Iran VI }\end{array}$ & $\begin{array}{l}\text { Feodor, for } \\
\text { Michael Romanoff } \\
\text { Divided, for } \\
\text { Feodor III }\end{array}$ \\
\hline
\end{tabular}

The third argument pointing in the same direction is drawn from studies in the pedigrees of monarchs. The inclivicluals who compose these pedigrees resided in various European countries. As a result of the policy of international marriages so common among royal families, a maternal grandfather of a French king may just as likely have been Spanish or English, yet the maternal grandparents are correlated as closely and are as similar in mentality to their grandsons, as the probabilities of heredity through the germ-plasm demands. I have shown in "Heredity in Royalty," " that royal persons resemble their maternal grandfathers as much as their paternal, and the correlations for individuals with all grandfathers and all greatgrandfathers is as high as is expected. The circumstances (conditions of the countries) which we might suppose acted upon and influenced the earlier generations were necessarily 
different from those acting upon the third or younger generation. Now if these circumstances had a significant importance, they would show that importance by lowering the correlation ratios for heredity. These are not lowered. The lines of great kings and princes had correspondingly great pedigrees. The only conclusion is that all the individuals developed as they did by reason of innate differences. The men moulded the circumstances, and not the reverse. "Without such a view we could not explain the pedigrees, for neither the men themselves, nor the events in which they individually lived, could have arranged the marriages of their ancestors of a hundred years previous." 1 In other words, the special conditions in any one country might conceival)ly have influenced the kings, but these circumstances could not be retroactive and form pedigrees. The conditions are correlated with the pedigrees. The conditions could not cause the pedigrees. Therefore, the monarehs are the results of the pedigrees, and the conditions the result of the monarchs. By this triangulation of reasoning the question is settled once and for all. No other explanation will suffice.

This does not mean that the surroundings have not played some share in the whole story, it does mean that such influences are trivial, illusive, and difficult to measure. It may be that both the monarchs and the conditions have been moulded somewhat by some extraneous forces, but here again these effects must be trivial, illusive, and difficult to measure. The absence of system in the arrangements of the symbols in Table II discourages a hope of finding any such forec, but I do not wish to be understood as saying that such a third category of forces may not indeed exist ; but the question is not, do environmental forces exist, but how great is their importance, and where and when are they to be found?

I have looked at the recorded evidence from many points of view with the wish to decide if the observed fluctuations in 1 "Heredity in Royalty," p. 218. 
material conditions of the various countries could be due to the immediate influence of the sovereigns, and have come to the conclusion that this is the only explanation consistent with all the observations. A further inquiry will now be made to see if there is any way of comparing royalty with other social classes, - those lying beneath them in point of inherited wealth, prestige, and power. Royalty has had exceptional opportunities and a peculiar and isolated position. It will not affect the general conclusion of this research, - which declares the positive and initiative influence of monarchs, whether one thinks that royalty as a whole has been much favoured by matters environmental, or whether one takes the extreme view regarding heredity and explains everything by inherent mental superiority. The influences are there just the same, no matter what be the ultimate source of these influences. Even if all the kings be thought really very stupid, and all the observable effects could be imagined due to blind and implicit obedience to the divine right of kingship, the influences and moulding powers of the monarchs on history would be just the same. Also the superiority might be real, but nevertheless favoured by education, or preferment, or any other external fact. The problem, up to the present, has been simply to measure the influence of $A$ on $B$ not to estimate the magnitude of $A$ in itsself, or to compare A to anything else.

I will now attempt first to compare royalty with other social classes in point of actual ability; and then take up the question of how far such ability depends on inherent (gametic) causes.

In "Heredity and Royalty," page 301, I made the assertion that there is no doubt but that modern ${ }^{1}$ royalty as a whole has been decidedly superior to the average European in capacity ; and we may say without danger of refutation, that the royal breed, considered as a unit, is superior to any other one family, be it that of noble or commoner. I have no wish to modify this extreme statement. Capacity is here used as meaning 
natural (inherent) ability, and the word family as one large interrelated group of persons.

Several converging lines of argument lead to the view here expressed, and it is not easy to see just why the statement should ever be disputed, except for the first thought that superior opportunities have been enjoyed by those born to the purple. While this is a very natural feeling, allied perhaps to human vanity and supplying the middle class with a comforting excuse for not aehieving more glory, such a view will hardly fit in with all the facts. Nor is there any good reason why a person should be any more ashamed of being born with a poor protoplasm than of being born with a poor environment, since both are matters of birth. Monarchs have cloubtless had very different opportunities from commoners, and in some ways they have had superior advantages, but in other ways they have had greater disulvantages, greater responsibilities to bear, and greater difficulties to overcome. It is diffieult to weigh one against the other, but granting for the moment that the advantages outweigh the disadvantages, is there any indication that such propitious opportunities have had a discernible effect in raising the estimation in which royalty has been held? First, is the reputed ability greater than the real ability? Second, is the real ability, such as it is, and whaterer it is, caused in part by envirommental differences? The answer to both these questions is the same, and is: Yes, but not to any great extent; not conspicuously so, not in an easy way, masurably so. The affirmative answer is given from a priori consislerations, from a feeling that there must be something to this side of the question. The qualifying and limiting clause is derived from the failure of tests to bring forth supporting evidence, and also from several considerations of a widely different nature. These may be enumerated as follows:

1. Younger sons of kings are not less eminent than heirs to the throne.

2 . The precocity of royalty.

3. Their success in government as compared with ministers. 
4. Their success in war as compared with non-royal generals.

5. Their genius or talents in other directions.

6. The proportionate number of recognized geniuses to the total.

7. The slightly excessive amount of insanity.

8. A priori considerations: Election of early rulers. Struggles and survival of the fittest.

(1) Comparing the eminence of younger sons with those who have inherited the succession, while it does not give a chance of directly comparing royalty with non-royal classes, does serve somewhat the same purpose. If evidence could be produced that the actual monarchs ranked higher in intellectual ability than their younger brothers, then we might infer that opportunity had aided the actual sovereigns in gaining their celebrity or reputed ability. As a matter of fact, the younger brothers are, according to the accounts of history, just as eminent intellectually as are the inheritors of the crown. ${ }^{1}$

(2) A large number of the seions of royal houses have been exceedingly precocious. Not that the early manifestation of exceptional talent proves the existence of genius, but precocity is one of the symptoms of genius, therefore its presence is to be expeeted and if found becomes an argument in favour of the genuineness of the reputed ability. Most of the prinees who were precocious in youth were great in maturity. William the Conqueror showed his incisive military genius before he was twenty-one. Henry I of England ruled wisely in the Cotentin when only twenty-one years old. Edward I, when only fifteen, became "the soul of the reconstructed royalist party," and at twenty-six defeated Simon de Montfort at Evesham and met the demands of a difficult crisis. Edward III took matters into his own hands when eighteen and soon reversed the declining conditions which had marked the reign of Edward II. William III of England, like Charles XII of Sweden, was a won- 
derful example of premature mental development. Charles XI of Sweden is also an example of precocious talents. When barely twenty years of age he brought his country out of a condition of disaster and anarchy and was unquestionably the initiator of all important movements from that time until his death. William the Silent received his first military appointment at eighteen, and was soon pitted against experienced and formidable opponents like Nevers, Châtillon, and Coligny, but held his own against them. ${ }^{1}$ In 1555 he was but little over twenty-two years of age, and he was preferred to the command, at a critical moment of the Emperor's career, over the heads of veteran soldiers much senior to himself. Even at that age he was more of a statesman than a soldier. ${ }^{2}$ Philip Augustus of France, "was but fifteen when he began to reign alone; yet, boy though he was, he never for a moment swerved from his course, or made a false step." Other great rulers who showed marked precocity were Louis XI of France, Isabella the Catholic, Margaret of Denmark, Gustavus I (Vasa), Charles IX, Christina and Gustavus III of Sweden, Ivan the Terrible and Peter the Great of Russia, and the Great Elector of Brandenburg.

(3) Another series of facts pointing to the mental superiority of royalty can be drawn from considerations concerning prime-ministers, their work, their personalities, and their total number. Richelieu was strong and Louis XIII was weak; Sully aided Henry IV of France; and Pombal, in the eighteenth century, remade Portugal. If it should be found that the total number of such prime-ministers exceeded the number of sovereigns supposed to equal them in natural ability, achievement, influence, or whatever serves as the criterion, then it would be something to the discredit of royalty. But even then (as the statesmen were drawn from many families and from a class numbering many thousands, whereas the great monarchs came from one interrelated family, and a total of less than one

1 Putnam, op. cit., i, pp. 54, 71.

${ }^{2}$ Frederic Harrison, "William the Silent," pp. 12, 13. 
thousand) it would not prove royalty inferior in natural ability to the nobles and commoners. As a matter of fact, the total number of statesmen alleged to be great is less than the total number of monarchs. This does not in itself prove the monarchs and the caste of monarchs superior to other castes; but it does present the sort of facts that one would meet were the royal breed actually mentally superior. Opportunity may have helped the monarchs more than the ministers; but, as differences of opportunity are shown by other tests to be usually of slight causative value, it is not at all likely that such differences of opportunity could account for the vast differences in the numerical ratios, - differences that make it thousands of times more likely than among average people that the breed of kings will produce a statesman.

(4) The same sort of indication is furnished by the records of monarchs as military leaders. Matching non-royal generals against royal, the comparison favours the generals of royal birth. There have been comparatively few generals of the first rank from other than royal families. Many others of subroyal birth have been placed in the highest command, so that it is not true that they have wanted opportunity. In this way the two classes can be fairly compared in terms of success and failure. The dozen greatest non-royal generals do not show any equal amount of success, or in any way the same evidence of genius. Marlborough is better remembered than Eugene, but the latter actually won more battles and with fewer men. Wallenstein is outranked by Gustavus. Even Napoleon belongs in part to royalty, since the great parvenu augmented the strength of royalty, inasmuch as he became royal and allied his family with royalty. Also the great changes and improvements in the art of war have been introduced (with the exception of Napoleon) not by generals who were of lower origin but by those actually born in the regal caste. All this falls in with the fact that the highest geniuses in this direction, those who are by all authorities acknowledged at the head of the profession of arms, tally the highest known number of eminent 
relatives close of kin. ${ }^{1}$ Therefore, the whole series of observations fits in with the theory of heredity.

(5) Monirchs and princes have shown their genius chiefly in war and government. They have become distinguished more as men of action than as men of thought. They have belonged essentially to the ult ra-practical type. But the domain of literature and poetry seriously claims a number of important royal contributors, chicfly in the olden times. Alfonso $\mathrm{X}$ in all probability actually descrves the credit of founding Castilian prose. He was the chief literary man of his generation. His grandson King Diniz occupies the same position in regard to the language of Portugal. He was the chief poet in a court famous for its romancistas. James $I$ of Aragon also is entitled to a high place in the early literature of the Peninsula. He wrote, in addition to other works, a chronicle of his own life, an artistic autobiography which has excited much interest apart from its historical value. All these men should be judged in comparison with their contemporaries, and so judged, they loom large, and also have the important merit of having been pioneers. There is some doubt if James I of Scotland wrote "The King's Quair," but if he dicl, he was a man of genius, and bears somewhat the same relation to the literature of Scotland. Charles of Orleans and Thibault of Champagne have a notable place in the history of literature, and Sancho IV of Castile and Juan Manuel, a nephew of Alfonso $\mathrm{X}$, must also be mentioned. Thus four of the early literary princes were closely related.

Among more recent members of royal families the amount of literary activity is great, though their productions seem hardly worthy of being deemed works of genius. If the question is made one of quantity of books published per thousand interrelated persons, probably no other group of a thousand persons could be found to match royalty. So that even on the side of mentality, where royalty is weakest, there is evidence of consiclerable activity; quite as much as is to be expected, when

\footnotetext{
1 See Galton, "Hereditary Genius," p. 141; Woods, "Heredity in Royalty," pp. 74-78.
} 
we remember that the qualities that first brought their ancestors into prominence, and have held their descendants in place, have been essentially practical rather than literary qualities.

In the domain of science (with exception of military science) their activity has been slight, never approaching genius and rarely exceeding the merit entitling them to be classified as patrons. Henry the Navigator is in a way an exception. He was doubtless the personal initiator of the great maritime discoveries of the fifteenth century. Everything points to his being truly a great character, a soul filled with grand ideas; but from the fragmentary information we possess he seems more of a colonizer and crusader than man of science in the strict sense of the word. It may be that the desire to make discoveries for their own sake, which is the distinguishing mark of the man of pure science, is so much a peculiar trait apart from other traits, that it is not correlated with those practical mental gifts for administration which eharacterize royalty and which at one time or another have been absolutely essential to the formation of dynasties and to their maintenance.

(6) The best argument in favour of the real and inherent nature of the intellectual gifts of royalty and their average superiority when judged as a single breed comes from thinking of proportionate ratios. If all questions are set aside except the total number of men of unquestioned genius as compared to the total within the group, a striking fact is brought out. In "Heredity in Royalty, "I showed that out of a total of 823 royal persons there were about twenty of the intellectual cminence of Frederick the Great, Peter the Great, Gustavus Adolphus, William the Silent, Eugene of Savoy, ete. Let this proportion (one in forty) be compared with the number of great men who arise out of a total population at any period or in any country, and the contrast is astonishing. There have not been at most more than two hundred men of such unquestioned genius born in any of the nations, England, France, Germany, or America, 
during their entire history. ${ }^{1}$ Each has had a population of twenty, fifty, or a hundred million or more, yet only a hundred or two hundred of such great geniuses have been produced. The differences are overwhelming. The chances in favour of royalty are several hundred thousand times as great. In other words, the average prince throughout modern times has a small chance of becoming a man of genius. There has been only about one chance in forty, but this is more than a hundred thousand times as good as the chances for an average child of average parents. Even if there be thought to be but two monarchs whose natural ability is granted to be equal to the natural ability of other great men, there would still be ten thousand times as many men of genius among royalty as is expected from the general population.

So there seems to be no way of getting around the fact that royalty hats far execeded the masses in the production of men of genius. The same is true for several grades approaching the modal or average type of royalty, as their supremely gifted types merge gradually into types less and less gifted. These average sovereigns are certainly more intelligent than the average commoner, probably superior to the average professional man, but I do not wish to lay particular emphasis on this point as it is nothing more than my own impression about the matter. I am not eoncerned for the present with establishing a measure for the medium or \pm grade for royalty, so much as with showing that there must have been very frequently enormous deviation in the "plus" direction. These are the persons who have so profoundly affected history.

(7) There has always been a great deal of insanity in royalty and this in itself is an argument in favour of the genuineness of their genius. The usual amount of insanity in a general population is less than 1 per cent. Among men of genius

1 Statement baser on a consideration of mental qualities of those in Cattell's list of the thousand most eminent men of all time. Published in Popular Science Monthly for February, 1903. 
and their kinsmen it is at least 4 or 5 per cent, and the same is true for royalty. ${ }^{1}$

Before discussing the a priori reasons for considering as valid the foregoing seven direct reasons, it will pay to summarize the general characteristics of royalty, as this will lead the way to clearing up the whole matter and bringing everything in line with modern ideas concerning the inheritance of particular traits. Enough has already been said eoncerning their mental ability. As for other important elements of character, courageousness is the attribute most frequently found. Only very few have lacked this quality. They have frequently been ambitious, often excessively so, but there is a considerable percentage of persons showing the absence or reverse of this trait. Selfishness, greed, and a thirst for power are very commonly found joined with ambition. Not satisfied with already wielding more power than any of their countrymen, and burdened with a plethora of worldly goods, the avaricious and domineering rulers have, seemingly impelled by inward instinets, continued to strive for more and more. A very common trait also is jealousy, though one reads the word more between the lines than in the direct statements of historians. Diligence, like ambition, is met with in fully one-half of all the rulers, but in perhaps a third it is replaced by sloth and indifference.

Cruelty and licentiousness alternate in about half of the cases with amiability and chastity respectively. Contrasts are everywhere met with; and these contrasts call for a great deal more study and along more exhaustive lines than can be presented just here; but as so little has been done to bring these psychological and ethical problems into touch with the facts of history, the two lists which I will here present are worth considering. In all probability the same contrasts would be presented by a more extended study, - one embracing all the modern rulers, or indeed any historical families who have been

${ }^{1}$ Havelock Ellis, "A Study of British Genius," 1904 ; Woods, "Heredity in Royalty," p. 271. 
sufficiently in the light of publicity. It will be observed that there is not any marked tendency for the cruel and licentious types to occur in the earlier ages. Also it should be noticed that intermediated types are not very common; even if all the doubtful persons are allotted to the medium grade including those who are obscure.

FRANCE

EARLY RULERS

\begin{tabular}{|c|c|c|}
\hline Licentious & Doubtful & Chaste \\
\hline $\begin{array}{l}\text { Philip I } \\
\text { Philip Augustus } \\
\text { Charles VI } \\
\text { Charles VII } \\
\text { Louis XI } \\
\text { ('harles VIII } \\
\text { louis XII } \\
\text { Franels I } \\
\text { Ilenry II } \\
\text { Charles IX } \\
\text { Ifenry III } \\
\text { ITenry IV }\end{array}$ & $\begin{array}{l}\text { Philip IV N.u. } \\
\text { Charles IV N.u. } \\
\text { Louis X N.M. } \\
\text { Philip V N.M. } \\
\text { John N.M. } \\
\text { Catherine de' Medici } \\
\text { Marie de Nedicis }\end{array}$ & $\begin{array}{l}\text { Louis VI } \\
\text { Louis VII } \\
\text { Louis VIII } \\
\text { blanche of Castile } \\
\text { Louis IX } \\
\text { Philip III } \\
\text { Charles V } \\
\text { Louis XIII }\end{array}$ \\
\hline
\end{tabular}

1 N.u. means no material exist to bear evidence ou this point.

ENGLAND

Early Rulers

\begin{tabular}{|c|c|c|}
\hline Licentions & Doubtful & Chaste \\
\hline $\begin{array}{l}\text { William II } \\
\text { Henry I } \\
\text { Richard I } \\
\text { John } \\
\text { Edward III } \\
\text { Humphrey, Duke of } \\
\text { Gloucester } \\
\text { Edward IV } \\
\text { Henry VIII }\end{array}$ & $\begin{array}{l}\text { Henry II } \\
\text { Edward II } \\
\text { Richard III } \\
\text { James I }\end{array}$ & $\begin{array}{l}\text { Willian the Con- } \\
\text { queror } \\
\text { Steplen } \\
\text { Ilenry III } \\
\text { Edward I } \\
\text { Richard II } \\
\text { Ienry IV } \\
\text { Henry V } \\
\text { Henry VI } \\
\text { Mary } \\
\text { Elizabeth } \\
\text { Charles I }\end{array}$ \\
\hline
\end{tabular}




\section{FRANCE}

Firly Rulers

\begin{tabular}{|c|c|c|}
\hline Cruel & Doubtful & Not cruel \\
\hline $\begin{array}{l}\text { Philip Augustus } \\
\text { Philip VI } \\
\text { John } \\
\text { Louis XI } \\
\text { Catherine de' Medici } \\
\text { Henry III } \\
\text { Marie de Medicis } \\
\text { Louis XIII }\end{array}$ & $\begin{array}{l}\text { Philip I N.M. } \\
\text { Charles IV N.u. } \\
\text { Louis X N.M. } \\
\text { Philip I X.M. } \\
\text { Philip I I N.M. } \\
\text { Louis Xll cruel in war } \\
\text { Francis I persecuted the } \\
\text { Huguenots } \\
\text { Henry I I }\end{array}$ & $\begin{array}{l}\text { Louis VI } \\
\text { Louis VII } \\
\text { Louis VIII } \\
\text { Blanche of Castile } \\
\text { Louis IX } \\
\text { Plilip III } \\
\text { Charles V } \\
\text { Charles VI } \\
\text { Charles VII } \\
\text { Charles VIII } \\
\text { Henry IV }\end{array}$ \\
\hline
\end{tabular}

${ }^{1}$ N.M. means no material exists to bear evidence on this point.

\section{ENGLAND}

EARLY RULERS

\begin{tabular}{|c|c|c|}
\hline Cruel & Doublful & Not cruel \\
\hline $\begin{array}{l}\text { William II } \\
\text { John } \\
\text { Edward IV } \\
\text { Richard III } \\
\text { IIenry VIII } \\
\text { Elizabeth }\end{array}$ & $\begin{array}{l}\text { Willian I } \\
\text { Richard I } \\
\text { Edward I } \\
\text { Edward III } \\
\text { llenry IV } \\
\text { Henry V } \\
\text { Mary } \\
\text { Charles I }\end{array}$ & $\begin{array}{l}\text { Steplen } \\
\text { Henry III } \\
\text { Edward II } \\
\text { Humphrey, Duke of } \\
\quad \text { Gloucester } \\
\text { Henry VI } \\
\text { Riehard II } \\
\text { James I }\end{array}$ \\
\hline
\end{tabular}




\section{CASTILE}

Early Rulers

\begin{tabular}{|c|c|}
\hline Not false, deceitful, cruel, or tyrannical & Opposite traits \\
\hline $\begin{array}{l}\text { Ferdinand I } \\
\text { Alfonso VIII the Noble } \\
\text { Ferdinand III } \\
\text { Maria (Regent) } \\
\text { John I } \\
\text { Henry III } \\
\text { John II } \\
\text { Isabella (except in her relation to the } \\
\text { Inquisition) }\end{array}$ & $\begin{array}{l}\text { Urraca } \\
\text { Alfonso X } \\
\text { Sancho IV } \\
\text { Ferdinand IV } \\
\text { Alfonso XI } \\
\text { Peter the Cruel } \\
\text { Henry II }\end{array}$ \\
\hline
\end{tabular}

\section{ARAGON}

Early RUlers

Not false, deceitful, cruel, or tyrannical

Opposite traits

Peter I

Ramiro II

Raymond Berenger

Peter II

Peter III the Great

Martin the Humane

Ferdinand I the Just

Alfonso I

James I

Peter IV

John II

Ferdinand the Catholic

The considerable number of early sovereigns in England and France who were either chaste or not cruel (merciful, kind, or benevolent) is to my mind extremely significant. The same lesson is drawn from the early history of Castile and Aragon. Witness the number of rulers who were not false, deceitful, cruel, or tyrannical. Why are historians continually explaining the bad characters by the influence of the habits and customs of the ages in which the individuals lived? "He was no worse 
than his contemporaries" is a phrase frequently met. It is easy to say and has a reasonable sound, so the reader aceepts it unquestioningly, but generally such statements are utterly contrary to facts. "Due allowance must be made for the age in which he lived" is another favourite phrase; but I should like to ask just what that "due allowance" is. The result of counting 568 cases of royal persons, all elasses and both sexes, has been to prove that vicious types of eharacter are not much more numerous in one age than in another, even if judged by "standards of to-day." 1

If the matter were gone into carefully, I have no doubt that it could be demonstrated that a slight inerease in the percentage of moral types marks each generation. But this is not the ehief or first fact. In deseriptive science we seareh for differenees, and here the most conspicuous differences are those which exist within one single generation, one age, and one country.

Now the significance of all this lies in the remarkable way in which the diversified facts fit into the theory of heredity. The expectations of gametic inheritance are fulfilled by every feature of the series of observations. There are two main sub-divisions to the argument. The first derives itself from the fact that the characters are contrasted. The second from the generalizations that have been made as to the mental traits of royalty as a whole. All the biological researches on the subject of heredity that have been reeently made have united in making it more and more elear that all inheritable eharacteristies tend to be segregated in the eourse of transmission from generation to generation. This segregation of separately inheritable factors is the essential feature of Mendelism as it is understood to-day. ${ }^{2}$ Thus, while the separation into cruel and non-eruel types, licentious and ehaste, ambitious and indolent, ete., is not clearly and absolutely defined, the tendeney to segregation which is observed is to be expected from the usual

\footnotetext{
1 The statistics for this conclusion are presented on page 293 of "Heredity in Royalty."

${ }^{2}$ Cf. footnote, p. 274, " Heredity and Royalty."
} 
workings of heredity. And furthermore nothing of the sort is to be expected as a result of environment.

In "Heredity in Royalty" I continually dwelt upon the phenomenon of segregation and its significance to those who aim at understanding human character. Therefore, the subject will not be discussed further, except to refer to the fact that a large number of recently compiled pedigrees show alternative inheritance for a wide variety of human characteristics, anomalies, and diseases. These include eye-colour, colour-blindness, night-blindness, hair colour and curliness, albinism, diabetes insipidus, split foot, polydactylism, brachydactylism, pulmonary tuberculosis, deaf-mutism, marked ability, chronic trophœedema, angio-neurotic œdema, hermaphroditism, hemophilia, imbecility, insanity and allied characters. If diseases and other peculiarities of the body are transmitted in the all-or-nothing principle, there is so much more reason for believing that peculiarities of the mind are transmitted in the same manner. It lends subsidiary support to the view which I advanced in 19021903 and have since many times defended, that it is impossible to understand human nature and the differences between one man and another except on the double assumption, first that the main differences are due almost entirely to inherent (predetermined or gametic) differences, and second that those differences tend to be inherited on the "all or nothing," "yes or no," "present or absent" principle.

Besides the confirmation which modern statistical researches and the development of the pedigree chart method of intensive analysis lend to the extreme view of gametic causation, another entirely different line of support comes from the biological laboratory, especially from microscopical research on the structure of elementary cells. Since 1901 it has become more and more generally admitted that the sex of the offspring is predetermined in the egg, and not the result of environmental stimuli. In many of the invertebrates (notably the insectivora) and in some of the vertebrates and perhaps among human beings, it has been proved that differences in sex are due to 
differences already present in the gametes from which these individuals are formed. The behaviour of the minute granules which in a nuclear arrangement govern the growth and functioning of these gametes, the number and arrangement of the granules (chromosomes), in a word, all the recently discovered phenomena in regard to sex bear out the view of the importance of predetermined causes. The same application is to be made of microscopical study of enzymes in relation to Mendelian heredity ; and finally it may be added that the researches concerning the causation of twins point in the same direction.

It is necessary for historians, psychologists, and sociologists to know something of the results of such investigations; even if it is impossible for them to follow the details, or to interest themselves much in these questions while they remain sub judice. They can at least avail themselves of the condensed conclusions as soon as these conclusions have passed into the domain of verified and accepted knowledge. If they fail to do so, they will surely be to that extent behind the times, and less able to understand human nature, either in the actuality of the present or a vision of the past.

(8) Another survey of the whole series of historical observations that have been made and arranged within this volume compels the same conclusions, both as to the genuineness of the heredity factor, and the supposed superiority of royalty. I refer to the a priori point of view. All the peculiarities which the members of royal families are found to possess in a more or less excessive degree are just the sort of traits that they ought to possess if heredity and germinal selection are the allimportant forces. The formation of royalty as a biologically isolated caste dates from very ancient times. The pedigrees of reigning princely houses of Europe usually go back in the male line to the ninth or tenth century. Lehr's genealogy ${ }^{1}$ gives also all the ancestors in the female lines. On viewing these fan-shaped pedigrees one can see at a glance that

1 P. E. Lehr, “Études sur l’histoire et la généalogie de quelques-unes des principales maisons souveraines de l'Europe." Paris, 1866. 
nearly the entire lineage of the royalty is made up either of members of the royal families, strictly speaking, or of the nobility. Of course if one could trace the lines far enough into the past, they would finally merge in the general population; but the point is that royalty, as a result of selection and breeding, has gradually been formed into a distinct sub-variety of the human race, and this process of separation has been going on for many centuries. During that time new men have been coming forward usually from the ranks of the nobility, rising in the social scale, and some of these have been themselves taken into the royal fold. Others, like the rich and powerful nobles whose daughters have married into royalty, are in that way included in the pedigrees. The caste of royalty is genealogically speaking surrounded by a fringe of the nobility without any definite demarcations.

That there has been a genuine survival of the fittest within the ranks of royalty there can be no question. The history of each country shows this. The kings who have been forced to abdicate, and the lines that have become sterile have been the weaker rather than the stronger. I have already proved in "Heredity in Royalty," Chapter XVII, that the inferior branches have left fewer adult descendants. A review of the reigning dynasties included in the present volume brings added proof that in the struggle for the possession of the throne the stronger rather than the weaker have survived and become the progenitors of future kings and princes. William the Conqueror was a greater man than any of the immediate kings of the Saxon time. Henry I defeated his weaker brother Robert. Henry II replaced Stephen. Henry IV was superior to Richard II ; William III to James II. Bruce won on his merits. William the Silent was greater than the rulers whom he displaced. The same is true of Gustavus Vasa, founder of the Swedish line. The weaker Sigismund was deposed by his stronger rival Charles IX. In early Russia there was much struggle and survival of the strongest. The Romanoffs began by the election to the throne of the able and judicious Feodor. In Portu- 
gal Alfonso III deposed his brother Sancho II and the line continued from its stronger stem. Also John of Avis, who became John I, was superior to Ferdinand I, whom he deposed. Examples of the selection of strong kings in early Spain are Sancho IV versus his nephew Alfonso, Henry II versus Pedro the Cruel, and the choice by James the Conqueror of Peter III of Aragon as his favourite son. Turkey furnishes many instances of struggles within the royal family. The military gifts of Orkhan (1326-1359) enabled him to gain the succession over his elder brother. The jealousy and rivalry among the princes of the house of Osman exceeded all bounds. The murder of younger brothers was a recognized custom. It is said that when the aged Sultana, who was a daughter of Mahommed I, came to Bayezid to move his fraternal feelings in Djem's favour, Bayezid answered with stern brevity by citing the Arab proverb, "There is no relationship among princes."

Also in the wars between the nations, the greater nations have all started with modest beginnings. Those nations that have never had great kings have remained small, or been absorbed by the larger. It can be easily shown that all the kingdoms that have remained small and unimportant have never chanced to fall under the guidance of men of genius. The bigger men, controlling as they did the bigger nations, fought against each other until the great absolute monarchies were constructed; and so much of Europe came as it did, in the fifteenth century, under the sway of four men, Charles V, Francis I, Henry VIII, and Suleiman of Turkey.

Besides contests among those already within the royal fold, to maintain their position or to gain a greater prestige, there have been at all times struggles on the part of the subroyal or noble classes, those wishing admittance within the consanguinity of the actual reigning families.

Thus history had been a process of natural selection. In the long struggle for wealth and power, royalty is merely a name applied to those interrelated families that have succeeded in getting and keeping the most of what most men want. Some 
branches of modern royalty have not recently added to their possessions and have been left in peaceful enjoyment of their estates for, say, two or three generations. This gives the superficial observer the idea that being born to the purple means ease without struggle. Nothing could be further from the truth. There may, or may not, be a necessary struggle to-day among scions of royal families; but as far as the past is concerned there has been a tremendous struggle, which epitomizes the ceascless human struggle and rises to the top, awe-inspiring from its duration, its listinction, and its success.

And what would be the traits most probably found in persons able to win in the old game of war and plunder? In the earliest days kings were elected; but for the most part since the tenth century, when the genealogical record begins to be authentic, the breed of kings has been macle up of such counts and barons as wore successful in war and government. For such suecess bravery is obviously a primary need. Ambition and energy, mental insight and alertness, are also essential. Greed, jealousy, cruelty, and licentiousness would not be drawbacks; the first two might indeed be aids ; but most important of all would be just those mental qualities, whatever they may be, that are essential to the leadership of men. These new men would reproluce their kind to very great extent, although it could not be expected that all their lescendants would equal them. The pedigrees of royalty are peppered with the names of men of genius, but also included in the pedigrees are the wives and the ancestors of the men of genius, and the ancestors of the wives of the men of genius. For this reason varying degrees of ability are met with both in the pedigrees and in the monarchs. So it is to be expected that some of the monarchs would be deficient in ability, or in ambition, or in any given trait. But the essential fact still remains, - the extraordinary high percentage out of the total of persons naturally able to do just that sort of work that fate thrust upon them. And this explains why (barring a percentage of exceptions) they have always been so eager and willing to take upon themselves the burdens and re- 
sponsibilities of their positions and, though having much, seek ever more and more. All living species represent adaptation. Had there been no adaptation, there could be no species and the same is true of this sub-variety of the human race.

Thus the a priori point of view fits in with all the facts and offers a single, simple explanation. The "law of parsimony" is satisfied. It is illogical to introduce further causes when a single, simple explanation will suffice. This single, simple explanation I will call "the gametic interpretation of history," but before discussing the use and definition of this phrase, I will take up at this point the important question of a possible bias on the part of historians that might falsely magnify my conclusions. I have postponed this discussion up to the present because only now have all the facts been brought together which when viewed and cross-viewed give a sufficiently clear reply.

\section{The Question of False Bias}

In Chapter II, I have much insisted on the need of distinguishing between random errors and constant errors. Random errors may be ignored if all one wishes is a lower limit to the degree of correlation. Constant crrors may sometimes be ignored or looked upon in the same way as the random crrors, provided it be known that they work towards lowering the correlation. Certainly they would then not lead to a false conclusion. Thus the constant error, that I have introduced by intentionally and continuously placing the doubtful cases in a way to count against personal influences, may be treated as an error which can eause no anxiety.

On the contrary, constant errors might tend to raise the eorrelation improperly, therefore it is important to consider the following possible source of fallacy. If historians have in their own statements overestimated the importance of kings, or if following sycophantic chroniclers, they have been inclined to overpraise the successful and underpraise the unsuccessful, then 
the correlation ratios would be thereby artificially raised. But a consideration of the whole question indicates a minimum of error from such a source.

There are at least five reasons for holding this error as probably slight.

(1) For the early history of some countries such as Spain and Portugal, the reports of a few chroniclers under royal patronage form nearly the whole of the source-material. The later history of these countries is much better authenticated and supported by more varied materials. If the later history did not exhibit the strong correlation which it does, one would suspect that the early history were fallacious. The later history shows about the same correlation as the earlier. Therefore, there is evidence that the chroniclers were not unjustly biassed.

(2) Also the nations which have been very exhaustively studied, such as Prussia and France, do not show a lowering of the personal influence; and furthermore these much studied countries show the influence just as strong even as late as the seventeenth and eighteenth centuries. All this tends to increase one's reliance on the opinions of the early chroniclers. It leads to a belief that the kings who were much praised or blamed were really not so very different from the pictures drawn of them by their contemporaries, or sometimes patched up by chroniclers hired by their descendants.

(3) Estimates of historical characters have been but rarely reversed. The estimate of Edward II, which Froissart made, has never been reversed. Richard III of England is an exception to the rule. As time goes on new evidence becomes forthcoming, but it is rare that a character needs to be much reshifted in the scale of estimates. Everything points to the great influences of great personalities within the periods and regions of well-authenticated facts; therefore, why should they not have been so in the age a little earlier? Special instances doubtless come up which arouse suspicion, but these are few in number compared to the total number of monarchs studied in this volume. 
(4) It must also be remembered that while more circumspect study sometimes lowers sovereigns in our estimate, sometimes, perhaps more often, the result of modern research is to act in the opposite direction. Therefore, it cannot be supposed that the correlation ratio is seriously affected or spuriously raised by the introduction of monarchs who are obscure or who are delineated only by partisan historians.

(5) Additional arguments are derived from a general survey of the whole material. The suddenness of the changes on the deaths of monarchs indicates that the historians have been telling the truth. Why should they have described such a multitude of reversals in the fortunes of nations unless these actually occurred? Why should they have described so many minorities as disastrous (when the government was divided) unless indeed they were disastrous? Furthermore, the distribution in pedigree charts of strong and weak kings in relation to their ancestry, particularly their maternal grandfathers, leads to the same sort of reasoning here as it did concerning the problem of whether the monarchs caused the conditions, or vice versa (see p. 240 et seq.). The strong contrasts between successive periods, the strong contrasts between monarchs close in period of time (which is expected by heredity), the rapidity of the changes are all in accordance with the truth having been told. It is highly improbable, virtually impossible, that historians could estimate all these monarchs incorrectly and make the latter generations tally with or properly resemble the earlier, - in a word, make the whole scheme hold together.

For the view of history which postulates the extreme importance of heredity and of selection, - this breeder's view of history as one might call it, - I have proposed the phrase "gametic interpretation of history." This is preferable to using the word "genetic," as genetic has so many different connotations and has been used and abused until it has a variety of meanings. Genetics merely means the study of successive generations. Of course history is genetic. Everything that has lived 
is genetic. Everything that grows is genetic. But the word gametic which is much in use among students of Mendelian heredity means something very specific. The gametes are the reproductive cells, both male and female. Gametically determined qualities (differences) among adults are those that develop because of qualities (differences) already present in the reproductive cells from which the adult sprang. It is not conceivable that all adult differences can be clue to gametic differences, but it is conceivable that nearly all important adult differences are foreshadowed by differences within the germcells (gametes), and a gametic interpretation of persons, families, dynasties, and nations is merely one which accounts for the great bulk of the observations in this way. "Gametic" is the antithesis of "environmental."

The question now comes up, can we separate heredity from environment? The answer from one point of view is, no; from another, yes. The gametes unite and form the new individual (zygote). The new inclividual must have an environment to develop in. So from one point of view the gametic and environmental forees are inseparable. But as soon as the problem becomes a problem of differences, it takes on an entirely new aspect. To prove that observed differences can be shown to be caused by one or the other and not both of these determiners, let us think of a simple illustrative experiment. An agriculturist cultivates two plots of ground side by side of approximately equal richness. He then sows a large amount of seed of equal average quality. He then applies a fertilizer to one plot and not to the other. An observed difference would in this case be due to environment. By the same method he could, by keeping the other conditions identical and changing only the quality of the sced, observe a difference which would be due to gametic differences. By this sort of reasoning it is already known in a practical way that a great number of valued variations (differences) in domestic animals are due to gametic differences, and not to environmental. Differences in colour of the hair and eyes are caused by differences in the gametes, 
while the linguistic differences among mankind are a good example of the action of environment. ${ }^{1}$

So it is with the interpretation which is given here for the influences of monarchs on political and economic history. It cannot be said that the monarchs caused the history or that they caused the conditions. But it can be contended that the differences between the conditions in one reign and the next were caused by the differences between the monarchs; and this is the quintessence of this research.

${ }^{1}$ Woods, "Laws of Diminishing Environmental Influences," Popular Sciencc Monthly, April, 1910; "Separating Heredity from Environment," American Breeders' Magazine, Vol. II, No. 3, 1911. 


\section{CHAPTER XVIII}

\section{CAUSATION IN HISTORY}

Is this chapter I shall make an additional speeial and minute analysis of one period already covered, in order to show that authorities do corroborate each other, and that out of a number of causes one cause stands out preëminently. I shall then diseuss other methods of unravelling historical causation and illustrate the need of a more exact and graphic representation of social and intellectual class-differences, and at the same time offer a new hypothesis for the rise and fall of the ancient oriental monarchies.

From 1415 to 1619 the duchy of Brandenburg maintained an equilibrium, or gained slowly and steatily in importance under a line of Hohenzollerm rulers either equal to or exceeding the average in ability and tenacity of purpose. During those two centuries there oceurred no period of decline, nor was there a sovereign elassified as weak. From 1619 to 1640 a sharp decline separated a strong reign, forty-cight years (1640-1688), from another reign of weakness (1685-1713), after which the grand expansion commeneed which culminated in the Prussia of Frederick the (ireat. Here, then, being a well-plowed historical ground, and in comparatively modern times, it is therefore an exeellent field for deeper and more seatrehing investigation, for practical illustration as to the possibilities of measuring and rorifying historical causation.

The first of these periods of decline occurred during the rule of the elector (ieorge William (1619-1640). The regeneration occurred under his son, the Great Elector; the second decline corresponds to the reign of Frederick I; and the second regeneration parallels the rule of Frederick William I, and Frederick the Great. 
At the outset one must try to gain as elear a proof as possible of the real mental and personal traits of George William, the occupant of the throne during the first of the debâcles. Perhaps George William was unjustly blamed for a stroke of fate. Perhaps, because the times were hard, the king was despised by his contemporaries, while modern eritieism has reversed the verdict. Perhaps the best historians will to-day be found to disagree among themselves. As a matter of fact historians do not take any other view than that George William was weak, though some like Voigt and Berner try to gloss over his failings and espeeially make a point of the difficulties of his position, coming as it did during the Thirty Years' War.

It will pay to look elosely into the question of George William's mentality and his relation to Prussia of the seventeenth eentury, for this prinee may be taken as an example of a typieal weak sovereign, placed in the "minus" grade on the basis of the usual statements. For this reason all the different authors are here quoted at the points where they make their most direct statement. Muirhead in the Eneyclopiedia Britanniea says: "This unfortunate prinee may be described as the first utterly ineompetent ruler of his line, though due allowanee must be made for the extreme difficulty of his position." A. W. Holland in the eleventh edition of the same work says that George William "proved a weak and incapable ruler." Aeeording to Tuttle: "To the vacillation, the duplicity of this prince may be ascribed the inglorious part which Brandenburg played in the great religious struggle" ... "a timid and capricious prince." Prutz gives the same idea: "He had neither nobility of ideals nor the sensitive eonseience to lead him aright through great disasters. His nature was superfieial." Pierson's comment is mueh the same: "The times demanded a prince of all ruggedness, and George William's nature was weak." Voigt, who does his best to exonerate George William's grandson, Frederick I (another inferior Hohenzollern), and is in general not in the least inclined to make harsh criticisms, shows by comparison with the high praise which he bestows on several 
other members of the family the slight regard which he has for George William. "This reign was one of the most unfortunate and harmful for the country. The Mark which since the end of the fifteenth century had been conserved for more than a hundred years in profound peace, by the wisdom of its princes, was dragged into the abyss of misery under George William. The cause for this has often been ascribed to the elector himself and to his chancellor, Adam von Schwarzenberg, without considering if the circumstances of the times were not more to be considered than the men themselves. One thing at least is incontestable and that is that George William's lack of energy increased the evil." The position of Berner is much the same. $\mathrm{He}$ is reluctant to say a word against the sovereign, yet he cannot say a word in his favour. He puts it in this way: "In truth George William, all too much, lacked the Hohenzollern energy and decisiveness." None of these historians, it should be noted, attempt to credit George William with any ability whatsoever. They do not mention ability in any of its forms.

Thus the picture is clear enough. Even if the last two writers had been alone consulted, the attitude they display towards George William, in comparison to their estimate of other Hohenzollerns, would result in the same grading. That is, - the Great Elector, Frederick the Great, Frederick William I, Frederick of Brandenburg (d. 1440), and Albert Achilles would enter the "plus" grade. Eight or ten others would go in middle or doubtful grades, and George William and King Frederick I (d. 1713) would just as certainly find their way into the "minus" class. This does not prove that George William was weak, but it does prove that the standard historians agree in so placing him. Furthermore, no change has taken place from the opinions of contemporaries by whom he was held in just as little esteem.

Now as to whether all authors may not have been very unjust and the man called weak because combinations of circumstances made him necessarily unsuccessful. This is 
possible, but it is extremely improbable. Combinations giving rise to great difficulties had occurred in the lives of the members of this same family many times before, and did occur many times afterwards, yet these princes were not regarded as nonentities, but were valued and praised for one trait or another. Some were considered vigorous, able, masterful, some merely shrewd and thoughtful, some quiet and plodding, or their virtue and learning came in for recognition where the mental qualities failed to arouse enthusiasm. Frederick, the first elector, had great difficulties to overcome at the very start. His successor Frederick II had to deal with the turbulent cities, and to balance Mecklenburg, Saxony, and Hesse, one against the other. Albert Achilles had to master Pomerania and Mecklenburg, while the affairs of the empire occupied his attention at the same time. His successor John (Cicero) did not have to face any great problems. Here was a prince living in an entirely different period from George William, yet history places him in nearly the same inferior class. John (Cicero) was, however, a man of learning, and therefore gets some appreciation over and above George William. Joachim I may be said to have lived in comparatively easy times. He is pictured as narrow-minded and plodding and a shrewd politician. Joachim II lived during the period of the Reformation. The dates of his reign are from 1535-1571. He found serious complexities enough in the urgent religious questions of the time, and had he not been a clever politician and guided by the best of intentions, might have allowed his country to lapse into civil war. John Sigismund, who reigned from 1608 to 1619, also had the religious entanglements on his hands; and he, also, dealt with them very successfully. More significant still, George William's son and successor had all the difficulties to overcome, which beset the father, yet this man not only brought the country out of its utter demoralization, but left it on the high road of prosperity. The sudden change is alone consistent with the view that the real trouble lay in lack of personal leadership from 1619 to 1640 ; and the subsequent events 
which followed the death of the Great Elector only the more certainly confirm the illea.

During the leadership of the Great Elector practically everything was in a flourishing condition. The nation was respected abroad and wonderfully active and progressive within its own, now considerably expanded, territory. The Great Elector was only twenty yaurs of age when the death of George William, distracted and disconsolate, left him his Augean task. He carried it through to a wonderful completion. A definite poliey was at once established. Crorge William had no policy at all. unless his actions as described by Carlyle can be called a policy, "where the Titans were bowling rocks at each other, George William hoped by dexterous skipping to escape share of the game." (icorge William expected to remain in neutrality, but it was a helpless neutrality and Brandenburg became erushed between Denmark and the empire: while the eastem posessions (Prussia) fell between the upper and nether millstones. sweden and Poland. The contestants in the Thirty Years' War had injured Brandenburg more than they lasl injumed ateh other. The new elector sought neutrality, but it was to be an armed neutrality. The first thing to be done was to get rid of the half-hearted chancellor, Schwarzenberg, who had been foolishly and obediently playing into the pocket of the Emperor. The elector then braved the anger of the Emperor and gave way temporarily in favour of Sweden; but with a shrewd rye, and with the provision that the Swedish troops shoukd he withdrawn from the electorate.

By first turning his artivities towards the army, by directing cvery effort to giving himself a weapon with which to back his claims, and command quest and attention, he was soon able to play one power against the other, to gain time in which to restore the wasted and scattered resouress of his country. This was done so successfully that in eight years, at the treaty of Westphalia (1648) Prussia was able by its mere military potentialities to lemand and receive excellent rompensation. The satisfactory results of the treaty of Westphalia could not 
have been carried through without an efficient army. This army, which had become one of the best organized in Europe, obviously came into being under the personal management of the Great Elector.

"The reign of the Great Elector forms one of the most signal instanees in history of the eonquest of adverse circumstances by personal energy and merit. At the death of Frederick William, the new north German State of Brandenburg-Prussia was a power that had to be reckoned in all European combinations. Inferior to Austria alone among the States of the empire, it was regarded as the head and patron of German Protestantism, its area raised to 43,000 square miles, its revenues multiplied fivefold, and its small army nowhere surpassed in efficiency. The elector had overthrown sweden and had offered a steady and not incffectual resistance to the encroachments of France." 1

Most historians have acknowledged the importance of royal and individual leadership in Prusia ; especially at this point in the story. Naturally they notice the right about face, which conditions take just here. The truth is more obvious than usual; but this is simply on account of the unusually contrasted types of character. The causative importance is not any greater here than clscwhere. It is merely more apparent.

Granting for the moment that the favourable reversal in the nation's fortunes rose from the change in leadership, it is profitable to speculate on a further set of questions concerning the common use of the word if. The failure of the reign of George William (1619-1640) has not unnaturally been aseribed to a number of causes, either isolated or eombined. Though it has seemed futile to discuss the question of "ifs" in history, and to say that if such and such an erent had not taken place then such and such consequence would not have followed, it may be of some clarifying value to show that there are probable and

1 J. F. Muirhead, Encyclopæedia Britannica. 
pertinent ways in which an "if" may be interpolated, as well as other ways in which such speculation is vague and vain.

Among the excuses usually offered for the first Prussian setback are (1) weakness of the chancellor Sehwarzenberg, (2) the chancellor's devotion to the Catholic faith, (3) the inefficieney of the sitates, (4) the jealousy and eorruption of the ministers and advisers who surrounded the eleetor, (5) the elector's own poor education, and (6) the general difficulties of the Thirty Years' War. Of course actual and inherent weakness in the personality of George William is also recognized; but the point is that, if we mention any other cause than this last one, the remark loses its pertinence. An open-minded consicleration of the various possibilities will bring out the difference between an explanation derived from the personality of George William and the above-mentioned first six explanations.

As for the character of Schwarzenberg, it is probably true (ats supported by the fatets contained within this book) that all would have been well if the chicf minister had been a great man. But the general history of Europe shows that able ministers were rare during this age, not nearly as numerous as able sovereigns, hence there was not any great likelihood that Prussia would find a man from non-royal ranks able to cope with the situation. Schwarzenberg favoured both Austria and the Catholic party, and as it turned out this was a bad policy, since, in the hinds of Austria, he was continually hoodwinked. But to mention this Roman Catholie allegiance as a eause of Prussia's downfall is not to the point. It is merely another way of saying that Schwarzenberg lacked discernment. A more able man might have known which party to favour, or perhaps it was unwise to favour either party. There is no way of telling. Perhaps a greater man, like Frederick William who afterward did actually become the nation's restorer, would have favoured neither party and built up his own integrity.

As for the inefficiency of the estates it is obviously true that if the estates had been sufficiently efficient, success would have stood in the place of failure; but here again there was little 
likelihood of a parliament at this time showing any concerted patriotism and organized intelligence. The same may be said about ministerial eabinets and the question whether the advisers of the king should be blamed for their personal jealousies and lack of light.

In the ordinary affairs of life we are not interested in postulating a very improbable if as a crucial explanation in the turning-point of a career. To take an extreme instance, - if a man were about to fail in business he would doubtless be saved if he diseovered a gold mine in his backyard. Though such a remark would be inane, it would not be considered otherwise than to the point if some one should remark he might have been saved had his stepfather died one day earlier than his mother, instead of a week later. The difference in our interest in the two ifs lies in this, that the second chance is not so remotely improbable. It might easily have oceurred. In the same way, if an untoward and mexpected aceident befalls a person we then say - if this had not occurred, ete. In the ordinary affairs of life, eommon-sense or unconscious knowledge of probabilities comes to our resene. The "fool" is the person who lacks the ordinary sense of proportion and consequently makes the foolish remarks. Ordinary common-sense will guide us up to a certain point in correctly allotting causes, but there is a vast ground covered with entanglement and obscurity which ean never be suceessfully plotted and measured by methods unsupported by the aid of instruments of precision. It is here that statistical methods may properly be introduced.

In the example of the man about to enter bankruptey, our personal knowledge of the man himself may in some eases make us very sure just where the trouble lies, but in other instances the eireumstances are too complex. It is a perfectly proper seientific question to inquire by statistical means how large a percentage of all business failures are due to ineompeteney, how many to lack of capital, panies, or to exceptional aceidents. This has been done and is done continually by the commercial agencies, although the returns are necessarily 
only an approximation. Although they do not help much in settling causes in the single instanee, they would help if it could be shown that any series of effeets is very strongly correlated with any series of causes. If, for example, all the men who failed once in business always failed again sooner or later, and another type was found that always went steadily ahead, it might be concluded that for practical purposes, and broadly speaking, the whole trouble lies always with the men themselves. Suppose for the sake of argument that a very high correlation were found, not a perfect correlation or one represented by unity $(r=1.00)$, but one of, say, nine-tenths $(r=.90)$. We should then be able to eonclude for the special instance if we knew nothing of the particulars of the merits or demerits of the case. We could express our opinion as to the cause, be guided in our expectations as to the future suecess of the individual in question; and all with a judgment now strengthened by a sense of proportion founded on probabilities. In other words, we depart from the position of the fool and his absurdly improbable suggestions as to eauses, and approach the position of wisdom, just in proportion as we are able to measure and express probabilities.

In this way an expression of opinion that the eause of the first Prussian downfall lay in the inherent weakness of the elector George William is a wiser remark than any other observation regarding the possible causes, for the simple reason that this is the more probable. There is more evidence that this factor in the totality might likely enough have been different, and there is more evidence that if it had been different, a ehanged eondition would have resulted. Why is this view as to the major cause, - that his inherent weakness was the real trouble, better than the view that his lack of education was to blame? As a matter of fact, George William did not have a poor education. But supposing for the moment that his education had been negleeted. My reply is that there is no evidence that differences in edueation have produced measurable effects on the personalities of royalty. Some eorrelation 
may exist, but this has not been proved as yet. From general consideration derived from various indications and modes of reasoning, this correlation is probably slight. ${ }^{1}$ There is on the other hand a great deal of collected evidence demonstrating that strength and weakness in royalty has resulted from heredity (combinations of the gametes) and is independent of ordinary environmental differences.

To summarize the conclusions: the inherent personality of the elector is the most probable and the most important cause. This fits all the facts well. There is nothing to be said against such a theory; and the analogies of history hasten to lend support, by prop and pillar, brought from regions remote in time and place. The generalization that weak kings are usually associated with weak periods is rendered probable by a variety of indications all pointing in the same direction. These are discussed elsewhere. Now if the generalization is correct for, say, ninety per cent of the instances, then it has nine chances in ten, in this particular instance, of being the principal cause. No other isolated factor can stand up in the turmoil of hazard like this factor. No other factor had been, or is likely to be proved to be, so reliable as this under all the complexities which necessarily go to form the shifting drama of history. Therefore, knowing nothing eertain as to the finalities of the actual reign under discussion, and remembering that no one can know, in the intricacies of the single instance, the "might have beens" that might have followed interposed and postulated ifs, the inherently weak nature of the elector remains as the best, most probable, and most important cause. To discuss the relative importance of the other six causes would carry me beyond the pretensions of this research, but this specific illustration has shown that the important underlying causes in history are not necessarily so difficult to demonstrate even for limited eras. In all attempts to unravel historical causation we must try to get explanations as far back as we can towards

1 See "Laws of Diminishing Environmental Influence," Popular Science Monthly, April, 1910, for a summary and discussion. 
first causes; the impossibility of ever actually arriving is no more a discouragement here than in the domain of those sciences whose length of life has been longer and whose oft-practised methods enable them to claim the adjective "exact."

\section{THE COMPLEXITY OF HISTORY}

It is sometimes erroneously thought that because an effect is the complex resultant of a large number of interwoven causes, it is hopeless to unravel the separate causes. Such may be true from the teleological point of view, but nothing can be further from the truth if the problem is looked at from the standpoint of everyday practice. If a motor car suddenly stops, the chauffeur is not concerned with final causes. He searches for the point or points that are not as they were before. He searches for differences. It is easy to give innumerable illustrations where practical problems of causation are made into problems of differences. For instance, the monetary value of introducing novelty of method into the management of a business corporation can be tested even though the intricacies of business management are infinitely complex.

Let it be assumed that factors $a, b, c, d, e, \ldots n$ are the same before and after the test, and that the novel factor $x$ is the cause of any change which may be observed. In strict truth, $a, b, c, d, e, \ldots . n$ never are, at any successive period of time, exactly the same; but if they are nearly the same it may suffice. Of course if $x$ is found to be small, and the other factors $a, b, c$, $d, e, \ldots . n$ are known for any reasons to change much, then only doubt and confusion could come to the investigator as a result of his laborious search. But in other cases $x$ may be found large enough to be unmistakable. A decision as to the significance and value of the results belongs to the problem itself. There is no characteristic aspect to problems of history and nothing inherent to separate them from problems of everyday life. The idea, often expressed, that history cannot be made a science, that causes here cannot be properly sought for, because the various factors $a, b, c, d, e, \ldots n$ do not remain the 
same, is an ill-founded one. In all the fluctuating realm of nature the subsidiary factors never do remain exactly the same. Even in the best cases that one can think of, the opinion that sueh and such a cause is the cause can be expressed only with a high degree of probability.

Why did a certain man die? He was killed in a railroad collision. But how do we know that he did not die of some undeterminable bodily ailment just at the moment before the train was wrecked? This is to the highest degree improbable; so much so that we accept it as impossible and eall the wreck the cause. Suppose it were a collision at sea and the man were drowned. Suppose the man were old and feeble and that some of the passengers in more robust health had been saved. We should still be unanimous in ascribing his death to the collision, if we had a belief (drawn from the probabilities of the case), that if this collision had not occurred, he would have lived much longer. Yet all along during the voyage the man's strength was declining. The eonditions were not the same at any two periods of time, but this change in the $a, b, c, d, e, \ldots n$ factors does not prevent our calling $x$, the new faetor, the main eause. But it is easy to see that these eases would gradually merge into cases which would give rise to argument as to the main cause of death. For instance, if all the passengers were saved but one, and if this one were in very poor health, say, in a dying condition, and died during exposure, it might be diffieult to decide whether his death ought to be ascribed to the shipwreek or not.

It is just the same in dealing with historical causation. Some causes are impossible to separate, but other causes ean be picked out as the real eauses to a high degree of probability. It is not necessary that the series $a, b, c, d, e, \ldots n$ should be exactly the same, any more than in the questions of everyday life; it is only necessary that they should be probably, approximately the same. The degree of this probability and of this approximation depends upon the necessities of the particular case. There is no inherent objection to the application 
of such methods to history any more than to psychology; for history is, after all, nothing but past psychology. Matters of history, it is true, never repeat themselves, but the same is true of everything else. In every problem the amount of accuracy required in the measurements depends upon the nature of the questions propounded.

Many historians and economists have fallen into the error of supposing that the "method of differences," as it is called by logicians, is not adapted to the historical and social sciences. In order to apply this method they say that we must have two instances which tally in every particular except the one which is the subject of inquiry. ${ }^{1}$ While this is true, if a very exact determination is required, it need not be read with such strict wording if a general and qualitative answer is wanted in the place of an exact and quantitative one. It is possible to imagine cases in which the expression "tally in every particular except the one which is the subject of inquiry" is made to read "tally in most particulars except the one which is the subject of inquiry." Here if the observed differences are comparatively great, we may be sure that the observed difference is a real eause of the result.

Take, for instance, Mill's illustration of the failure of the "method of differences" to decide on the causative value of a protective tariff. It is true that it is impossible to find two nations which are exactly alike in every respect excepting only in the presence or absence of a protective tariff. But if all the nations in the world had a high protective tariff, and one of them suddenly abolished it and at the same time greatly declined or rose in economic strength in comparison with the others, we should be justified in postulating as our hypothesis the tariff change as the cause of the variation. If this were observed repeatedly, it would become more and more probable; even though all the nations differed in many particulars. The reliability of the conclusion would depend upon

${ }^{1} \mathrm{H}$. W. Farnam, on the contrary, makes a strong plea in "The Economic Utilization of History," Yale University Press, 1913. 
the magnitude of the change and the repetition of the observations, and might theoretically even become independent of the varying particulars within the nations themselves.

The possibility of answering any problem of historical causation must be decided on its own merits. We cannot tell until we try. If the observed difference is small we may be forced to abandon the analysis or inclined to give up the problem as affording too little certainty. If, however, a single observed difference be great, or, better still, if a repetition of similar differences (of considerable magnitude) be found running through a long period of historical time, we may have a result which can be rightly made to mean only one thing. The dynamic factor which history presents is its strong point as compared with sciences like sociology, pedagogy, and psychology, where the observations have been made only for a short time. The differences which permeate history, "running differences" one might call them, are very important; and it has not been appreciated what a great boon this time element is to the historiologist. Like the paleontologist his record is often faulty and uncertain in spots; but the wide, sweeping curve over which he can view the panoramic changes makes it possible for him to see the trend of things and discover their causes in a way that would be impossible if he were obliged to concentrate his attention upon one age or one level of world strata.

The time element of history, with its long series of repeated phenomena and its visible slowly moving points of change, outlining broad curves of recognizable contour, often teaches more than is revealed within the limits of the story itself. For it often gives a hint of what is to come. Within the units and minutiæ, saltations may be found, but in a larger way nature makes no sudden changes; the things which were will continue to be, though never just the same. Still, for a time the same phenomenon will be likely to persist; and that is what gives a study of the past its practical value to the needs of the present and, in default of better prophecy, its claim to be indicator of the tendencies of the future. The personal influence 
of a few very great men is a phenomenon that doubtless started at a far earlier date than I have traced it in this volume. It was unmistakably of very great importance in Greece and Rome and even greater in Persia, Assyria, Babylonia, Jerusalem, and Egypt. Just how far back into the past, and in what neighbourhoods one must go to see the force at its maximum, cannot be said; but there is every reason to suppose that, looking backwards into the origins of human society, there was a time when the force was not nearly so great as it afterwards beeame.

As the evidence stancls, we may accept ten centuries in Northwestern Europe as a low limit for the duration of the importance of this power of royal or other personal leadership. Most of the fourteen nations have not been tabulated for centuries earlier than the fiftcenth; but the most cursory reading of the histories of earlier centuries shows the same coincidences, though the obscurity and confusion make all but the most towering personalities and the most notable material changes difficult to ristinguish and unsafe to measure.

It is unlikely that a phenomenon which started as long ago as the tenth century, and continued unabated in most countries until the end of the eighteenth, should abruptly cease. The influence of monarehs in the nineteenth century must have been considerable. Napoleon, Alexander I of Russia, Leopold II of Bolgium, Franz Joseph, and the Kaiser William II are positive forees that need to be reckoned with, as are the statesmen Bismarck, Gladstone, Disracli, Salisbury, Cavour, and Metternich; while on the negative side the absence of statesmen of the first rank in minor and backward countries must also be taken into account in explaining political transformations. In many nations it would seem that the personality of the monarch is almost as important as ever.

The facts brought forward in this volume must undoubtedly to a considerable extent support that view of history which attaches importance to the "great man" as a moulder of circumstances. The facts, more than anything else to my mind, 
prove that whatever be the mental differences between the ordinary man and the man of genius, the differences are of great importance if judged by the results of their power. It is not easy to measure mental differences except in terms of achievement; nor from the standpoint of history do we much care what the natural talents of men may have been if they have failed to put them to the practical test. If from the pragmatic standpoint men differ much among themselves, and a few men may rise very conspicuously out of the masses in some nations and at some periods, then how very important it becomes not to think and talk of any people as if the individuals were all alike. To speak of "the Egyptians," "the Romans," "the Greeks," and "the English" without taking into account this question of intellectual and social variation within the nation, is to talk in the loosest and most confusing way. "The Egyptians" as a whole probably never hat any highly developed building instinct, though some of their rulers had. "The Greeks" as a whole may never have been artistic and intellectual, though a percentage certainly were. "The Romans" may never have had a special faculty for law and government. Such talents may have been confined to the patrician families. Indeed the Roman people may never have declined for the simple reason that the Roman people may never have risen. The free citizens of Greece disappeared. They never were numerous. The Roman patrician families disappeared. They formed but a small proportion of the total population.

The important point is that no investigations into the decline of countries can succeed without taking into account this matter of class differences and the approximate distribution of intellectual qualities. Such distribution, if represented graphically, must in the nature of things be different for different nations. As there are no two leaves on the same tree alike, so no two national curves of this sort could be just alike. Our present knowledge does not allow us to draw these eurves with all desired accuracy, but it does enable us to sketch three extreme types of curves, and these graphs will at least help to clarify 
much that I have had to say in former chapters, and also aid in an explanation which I am about to offer for the rise of the oriental monarchies of antiquity.

If all the inhabitants of any community were made to stand in single file and a line were drawn along the tops of their heads, such a line would trace a curve something like half of a very broad bell (Figure I). Intellectual stature, natural ability, or ability judged by achievement, we may be sure, would also give a curve of the same general shape, though we do not know just

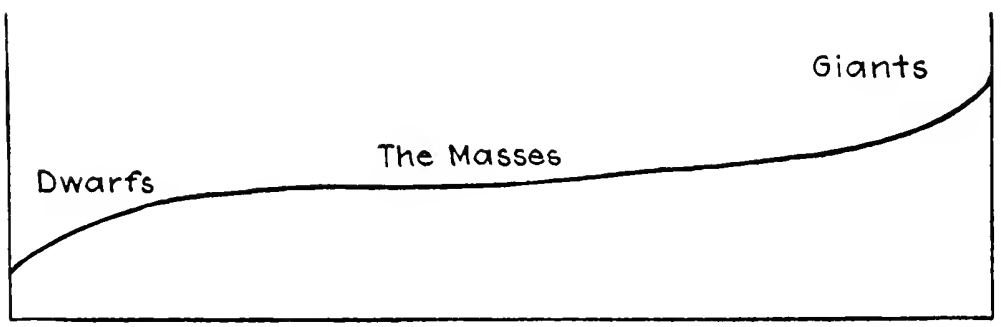

FigURE I.

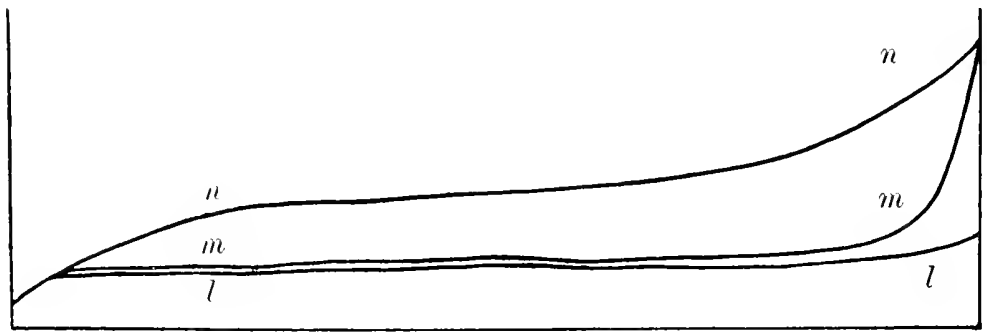

FigURE II.

what its precise form would be. One way to gain some insight into the form of the curve for any one historical period is to measure the importance of a few leaders as against the masses. If the nation has gained ground without the leadership of such men, then there is not much rise to the curve at the right as 
compared with its centre. (Curves $l-l$ or $n-n$ express this distribution.) But if the converse is true, then the few are much above the masses and the curve $m-m$ is fulfilled (Figure II).

For the period of history covered in this volume, Spain, Portugal, Turkey, and indeed most European countries would conform more to type $m-m$, while Great Britain since the seventeenth century would be represented by the line $n$-n, with perhaps a greater percentage of defectives and dependents, certainly a higher position of the masses, and a more gradual rise in the curve towards the right.

The lower line $l-l$ represents the mental distribution in savage tribes, the stage of evolution where hunting and fishing are the sole or chief means of livelihood. An example is furnished by the North American Inclians of the United States at the time of the arrival of the Europeans. North of the tropics no great civilizations, so called, were found, no dynasties, no great kings, no men very much raised above their fellows, but all very much alike and all possessing such skill and force as gave them adaptation to a life in the wilderness. In the regions to the south, on the contrary, in the warm lands of Mexico, Central America, and Peru, complex civilization had been established, and powerful monarchs ruled over widely extended political groups and controlled the lives of myriads of people. The type of curve representing their state of society is of the order $m-m$.

Now it requires very little historical observation to see that the first great civilizations of antiquity found their cradles in the warm and fertile regions of the globe, within the tropies or near the tropics; always where the cultivation of the soil was easy and particularly in broad river valleys like the Nile, the Tigris, and the Euphrates. Furthermore, all these earliest civilizations as far back as one can trace them by their monuments, even to their earliest beginnings, are always found under the eontrol of dynasties of reigning monarchs. My hypothesis to account for both the appearance of the civilizations and the evolution of monarchial governments is as follows:-

Whether man first originated in that part of the world where 
the Indian Occan is now, or somewhere else, it is certain that he first made his appearance in a warm country; also he must have from the first lived in groups or gregarious bands. As he multiplied he pressed farther and farther into the cooler regions. Not only would the more ambitious and energetic be the ones to depart, but long generations of life in the more rigorous climates would, by natural selection, eause an increase of the attributes, ambition, and energy. Man would become arlapted to the hunter stage of civilization, to living in small groups or tribes. Such a condition may be pietured for Central Asia amel Europe during long cons of time. Let any of these northern peoples return to the tropical river valleys, they would be ablo to conquer races that hacl never left the tropies - races that had never by natural selection alepuired the qualities of ambition and onergy. They would rither exterminate the inferior tropieal races or would hring them into slavery. In any event there would then take place a new set of changes eausing a differentiation of all the people: A change from the type represented by the curve $l-l$ into that represented by the curve m-m. It is not that the northerns arrived in the valleys of the Nile, the Tigris, and the Euphrates, and the fertile regions of Ameriea already men of genius, already capable of cont rolling vast armies, eonstructing great monuments and predicting the movements of the statrs; but it is that only in such regions could the evolution sperdily take place of castes mentally alert and superior to the masses, - castes from which men of genius would be likely to arise. The ehange within the community from type $l-l$ to $m-m$ is the kermel of the whole explanation.

The reason for this change lies:-

(1) in conditions of the climate and soil making agriculture easy ;

(2) in the accumulation of wealth;

(3) in legitimacy of descent ;

(4) in sexual selection;

(5) in mental inheritance.

In the hunter stage of society the accumulation of wealth is 
not easy. Meat and fish soon spoil. There is no surplus to be striven for among the different members of the group, no property to be handed on to the next generation, no rights in land and buildings, cattle, corn, and slaves. But in a fertile agricultural country all these forms of wealth may become the objects of the fiercest warfare. The tropical man, strictly speaking, (the Ethiopian) does not now, nor did he ever, exert himself to acquire wealth. Wealth has no meaning for him. He does not want it, would not know what to do with it if he had it. He profers his simple cabin and his life of good-natured ease. Warfare is between one tribe and another, not intratribal.

It has been wrongly thought that this laziness and indiffirence of the tropical man is caused by the direct effeet of the warm climate, but this cannot be true. It is not the lirect but rather the indirect effect of the climate; a question of natural selection. It is because none of his ancestors have ever lived for long periods of time where natural selection could produce the opposite qualities. This must be so, for otherwise how are we to account for the fact that in the hot climates there was at one time so much activity, indeed the earliest of the great mental awakenings of humanity, the beginnings of recorded history of architecture and of accumulative thought? Civen a set of people now possessing ambition and energy, and in a territory where the accumulation of wealth is a natural phenomenon, there will inevitably take place a struggle. Even if the people differ very little among themsclves, there will necessarily be some more desirous than others to aequire, and more able than others to have and to hold. Some will get more than their share, and as soon as this differentiation begins, it at once becomes self-accelerating, and for the following reasons.

When the possibilities of amassed permanent wealth are introduced into the life of a community and some men are acquiring more than others, since life is short and none carry wealth beyond the grave, there soon arises a desire to bequeath this wealth to the close of kin in the next generation. In the earliest forms of society a loose relationship suffices. Descent 
of rights through the mother or through the sister suffices. But with greater property comes greater desire to know the exact, relationships, and the father wishes to know his own son, to whom he will lave his aceumulated wealth. This means the beginning of family, in the modern sense, with legitimacy of descent through the male lines. In other words "father right" takes the place of "mother right."

As soon as property is transmitted, and some fathers of families possess more wealth and power than others, and some sons and daughters are prospectively the heirs to more property than other's, there will naturally arise a desire on the part of parents to unite their children in marriage with the children of other rich men. The ambitious will be more inclined than the umambitious to seek such unions. The ambitious and energetic are on the whole the ones who have succeeded most signally in acquiring the property. Probably the more ambitious are on the whole the more able. Whether or not this last statement is true, certainly those who have most aequired property will, on the average, be the ones most endowed with ability so to acquire it. No matter how much the question of good luck may enter into their suceess, good luck will have to balanee bad luck in a large number of cases, and the most successful will have to average the higher intelligence as far as intelligence means the practical acquisition of wealth and power. Thus the richer and more intelligent families will by the foree of marriage unions (sexual selection) be brought together, while the poorer and less suecessful will be left to marry among themselves.

When the rich and suceessful men were giving in marriage their sons and daughters to the sons and daughters of other successful men, they were secking an immediate advantage for their family; but they were really raising their families more than they supposed, for they were introducing the possibilities of new hereditary variations around higher levels. It is true that all the children of such selected unions would not equal their parents, some would revert to the general average level. But some would even exceed in natural aptitude the average of 
their parents. Thus in each succeeding generation on the average there would be some whose natural ambitions and ability to hold and control large fortunes would exceed any who had lived in the previous generations. The individual exceptions to this tendency will make no difference except to delay the process. The whole matter hinges on the question of mental heredity. If mental qualities are inherited in the same way and to the same degree as physical, then this process of differentiation must take place wherever there is a large community and wealth is sought for. In a state of civilization where sympathy and charity are at a minimum, there soon becomes no room for a man who is not of either the lower or the higher caste. The people of the lower caste are allowed to remain because they are willing to serve their masters. Any men of the middle class who become pretentious are ruthlessly cut off. The process works towards forming more and more a caste small in numbers and smaller in percentage to the total population, but at the same time in point of power and intellect more and more raised above the general population. The high wave once formed, the struggles within the superior caste (for it must be remembered that these are the people most ambitious and grasping) tend towards the survival of only a few ; and lastly one family, the royal dynasty. Those willing to serve the dynasty and the ruling order of society (as the monarchs wish lieutenants, soldiers, and priests) are allowed to survive and the curve $m-m$. with its aristocracy of the intellect, ${ }^{1}$ is formed.

In the course of time there are so few persons in the extreme. upper caste, and the whole nation is so dependent on their guidance, that a new danger is introduced. The whole had been formed into a sort of waterspout structure, the slender point of which, growing higher and higher and narrower and narrower, is liable to break. This is just what has happened so often in history. The whole civilization of the nation, depending on

1 There never was an aristocracy that was not an aristocracy of the intellect, and there never was an aristocracy that was not an aristocracy of wealth. 
the brain power of a few persons, soon passed away when those few were destroyed.

Such I believe to be the true account of all the early states of civilization, and such was to a considerable extent the supposed strength of Spain and Portugal, and several other nations of more recent times, though their dymasties were not selfengendered out of native stock.

These latter dynasties, like all other modern European dynasties, were evolved out of the Germanic races - Norsemen, Scandinavians, saxons, ete. The same five fores led to the same series of social and intellectual differentiations - the waterspout formation with the governing caste more and more elevated in natural ability at the same time fewor and fewer, not in actual numbers but in pereentage of the whole population. This phenomenon did not take place in the north, any more than it clic in the south, mit the people passed from the hunting stage to the agricultural stage, until accumulated wealth became an object for intratribal competition. It was slower and later in the north because agriculture was more difficult. The curve also started in the northern countries from probably a higher general level; that is, the great mass of the people in Germanic and the northwestern countries had, even before the days when agriculture became the chief source of wealth, alrealy acquired mueh in the way of mental alertness, and instincts of industry and ambition.

On the whole it secms probable that the curve for modern Europe at the present time is more of the order $n-n$ than $m-m$, at least in comparion with the civilizations of antiquity. Just why it is so we do not know, but it is perfectly clear that there are always at work two sets of forces, - one which we may eall the aristocratic force tending towards the formation of $m-m$; the other, which we may call the demoeratic, tending to reduce the curve. The democratic force is made up for the most part of impulses belonging to the milieu, to ideas, institutions, combinations on the part of proletariat, revolutions, diffusion of rights of suffrage, and perhaps to the greater extention of edu- 
cation. It is not the province of the present book to discuss this - the environmental side of the question; but it is the generalized conclusion from the facts here collected and reviewed, that as far as the greater portion of human history is concerned, this levelling tendency cannot have equalled its opposing force - for how otherwise could the supremely important few have been engendered? The aristocratic force in made up of impulses lying in the germ-plasm. Its consequences have been continually coming to the fore. No matter what may be the form of government, nor how much the laws of man give power, in theory, to the people, as long as sexual selection tends to mate like with like, just so long the laws of mental heredity will work towards the formation of governing .classes inherently superior to the sons of other men. Universal suffrage and universal education, the most curefully equalized seheme of social opportunity cannot prevent this tendency of the homogeneous to pass into the heterogeneous, - this splitting up of mankind into sub-rarieties, castes, and breeds. It is part of the trend of organic evolution. Nor does all this fail to have a significance in relation to the future. It is probable that this separation into castes is increasing rather than diminishing at the present day in all European countries and especially in the United States, where the opportunities for acquiring wealth are particularly abundant. Historical science can scarcely at present predict the future, but it can interpret the past. If the work of the world has been initiated and directed by a few very great men, and if these men are the predetermined produets not of outward but of inward differences, the true interpretation of history must hinge upon the gametes, and the laws of history will be found to be but a part of the laws which govern all organic life. 



\section{APPENDIX I \\ BIBLIOGRAPHY FOR FRANCE}

a. Eneyelopædia Britannica. 9th and 11th editions.

b. La grande Encyclopédies. 31 vols. Paris, 1S86-1902.

A. Lavisse, Ernest (Editor). Ifistoire de France, depuis les origines jusqu'à la Rérolution. Publiée avec eollaboration. 9 vols. Paris, 1901-1911.

B. Duruy, Victor. Histoire de Franee. Nouvelle édition illustrée. 2 vols. Paris, 1870. - BB. same. Paris, 1879.

C. Kitchen, G. W. A History of France. 3 vols. Oxford, 187377. [A widely read text-book.]

D. Martin, (Box Lovis) IIexri. Histoire de France depuis les temps les plus reculés jusqu'en 1789. Nouvelle édition revue et augmentée. 4th ed. 17 rols. Paris, 1860-62.

[Consulted for the less reallily aecossible periods.]

E. Vuitry, Adolpile. Ftudes sur le régime finaneier de la France avant 1789.2 rols. Paris, 1883.

F. Levassecr, Pierre Finfe. Histoire des classes ouvrières et de lindustrie en France avant 1789.2 d edition. 2 vols. Paris, $1900,1901$.

G. Benr, Adolf. Allgemeine Geschichte des Welthandels. 3 vols. Wien, 1860.

[A compilation, very useful for statements concerning commerce and industry.]

H. Wright, J. H. (Elitor). A Ilistory of All Nations. 24 vols. Philadelphia, 1905.

[Sparingly consulted to fill in lacunæ.]

J. Guizot, F. P. G. History of France. 3 vols. London, 1880.

$K$. Dareste, C. Histoire de France. 9 vols. Paris, 187t-80.

L. Gibins, H. de B. The History of Commeree in Europe. London, 1891. 


\section{FRANCE}

RILER

Hugh Capet

Prudent, brave, eonciliatory, and politic, perhaps unscrupulous, pious. Altogetler an enigmatical person, about whom too little is known to form a fair opinion. $a ; b ; A$ ii, pt. ii, 144 ; $B B \mathrm{i}, 211 ; C \mathrm{i}, 191$.

\section{- $\quad$ Robert II}

Weak and prone to insouciance. Pious and kindly, beloved by his people. Literary tastres. $a ; A$ ii, pt. ii, 153; $B B$ i, 214-5; ( $\quad$ i, 19.5-6; $/ 1 \mathrm{ix}$, 86.

\section{Henry I}

According to some authorities he was weak and extremely indolent. Others think he may have been guite the reverse. There are no conteniporary reoords by wheh to julge him. $a ; A$ ii, $p$ t. ii, 167 ; $B \mathrm{i}, 221 ; C \mathrm{i}, 2(2)$.

\section{\pm or + Minority of Philip I}

Baldwin V, Count of Flanders, Regent

llo was a son-in-law of Ilenry I, was able and enerectic and well liked by the prople. $a$; H ix, 87.

\section{Philip I}

Of fair natural caparity, but lacking in ambition, inclustry, and eourage. False, dissolute, grossly sensual, and without homour. "The weakest of the Capretians." $a ; A$ ii, pt. ii, 165 ; $B$ i, 227$8 ; C \mathrm{i}, 205,212,249 ; 1 / \mathrm{ix}, 87$.
CONDITION OF COUNTRY

\section{$987 \quad 996$}

$\pm$

Country pacified, authority establishred. France definitely separated as a kingdom distinct from Germany. A $\mathrm{ii}$, pt. ii, $144 ; 149-153 ; B$ i, 214; C i, 184.

996-1031

An inglorions reign. Civil wars and ronstant struggles against barons. a; A ii, pt. ii, 159-61: B i. 215, 219; C i, $197-9 ; / 1 \mathrm{ix}, \mathrm{b}$.

\section{$1031-1060$}

Kingdom invarled by the Normans. Diseord and petty warfare. $a ; A$ ii, pt. ii, 161-3; B i, 221; ( i i, 200, 202, 209.

Order maintained and sedition suppressed. a; $B$ i, 227; (' i, 20s; $/ 1 \mathrm{ix}, 87$.

1067-1100 or 1108

Interminalue petty warfaro and desolation. Frencli territory invaded by the Normans, who scized and burned Mantes. $A$ ii, pt. 168-75; $B$ i, 227-8, 257,$283 ; C$ i, 209, 210, 213; $H$ ix, 87 . 


\section{RUler \\ $+$ \\ Louis VI}

Able, brave, strong and generous. A noble charaeter. Pure in his private life. Universally esteemed by the people. $a ; b$; $A$ ii, pt. ii, 311-3; $C$ i, 250, 258 .

\section{\pm or - Louis VII}

It is difficult to gain a clear idea concerning this king. Not much is known about him. He was pious and was praised by the monkish chroniclers. In ability he was probably not above mediocrity, was well educated, just, and liberal. "de mours pures" (Lavisse). $a ; A$ iii, pt. i, 22, 25, 26, $27,59-63,76,78 ; B$ i, 301-3, 304, 307; C i, 261, 262, 263, 266, $275 ; H$ ix, 87.

\section{$+\quad$ Philip II (Augustus)}

A eold, clear mind. Crafty and sagacious. Equally able in war and diplomacy. Charged with deceit and lack of generosity. Materials for a moral portraiture are meagre. Was at least more or less a libertine. $a ; b ; .1$ iii, pt. i, 222, 282-4; $B$ i, 324; $C$ i, $276,287,314$.
Condition of Country

1108 or $1100-1137$

Establishment of national unity and authority over the lawless barons. Better days for the lower elasses. Beginning of the organization of the communes. Increased power over the crown. Many eathedrals built. $b$; $A$ ii, pt. ii, 314 ; $315-25$; $328-9$; $B \mathrm{i}, 285,290$.

\section{7-1180 \pm or +}

During the first part of the reign, in spite of the disastrous crusade (1147-1149), good financial management and internal order maintained under Suger. Trade and agriculture made some progress. After 1152 the country declined in dominion and resource; against which may bo offset the growth in town life and eoncessions to the lower clisses. Royal authority gained in importance. $a ; b ; A$ iii, pt. i, 22, 25, 26, 27; 59-63; 76,$75 ; B$ I, 301, 303, 307; $C$ i, $262,263,266,275 ; H$ ix, 87 .

\section{0-1223}

France unified and greatly strengthened. Normandy, Poitou, Touraine, Anjou, Vermandois and Picardy conquered. Order and security maintained. Cities grew. Industry and commeree improved. Financial administration good. A iii, pt. i, $89,97-8$, 129-43, 151, 197, 211, 222-7, $232-8,238-50$; $B$ i, 309, 321, 322,$324 ; C$ i, 276, 277, 286, $296-7,312,313,315$. 
RULER

Louis VIII

Authorities differ as to his ability. Some credit lim with vigour and understanding, others call him weak, and attribute his artivity to the promptings of his queen. He was pious and chaste. 4 iii, pt. i, 284; $(2 \mathrm{i}, 316$; $D$ iv, $131 ; J$ ii, $116 ; K$ ii, 190.

$+\quad$ Minority of Louis IX

Blanche of Castile (the queen mother) Regent

Firm, prudent, mastorful. Exreptionally able and ambitious. Proud, imperious, and stradfast in her friendships. A good mother. Her chiof faults appear to have been obstinary and jealousy. $a ; b ; A$ iii, pt. ii, $5 ; B$ i. 321 ; $C$ i, 319, 321; D iv, 133-4; $H$ ix, $25 \%$.

$+\quad$ Louis IX (Saint Louis)

A great ling and a great man. Firm, energeti", and just. Wise and profound. P'ious, atferetionate, conscientions. Ilis private life temperate and pure $a ; A$ iii, pt. ii, $18-40 ; B$ i, $32 \mathrm{~s}$; $C$ i, 337,340 .

\section{Condition of Cocntry}

\section{3-1226}

English lost half their possessions in France. Sulmission of lower Poiton. Limoges, and Périgord. Sucerssful but eostly crusade against the Albigenses. $A$ iii, pt. i, 284-95; $B$ i, 325, 326 ; $C$ i, $316 ; H$ ix, $250 ; \mathrm{J}$ ii, 116 .

$1226-1236$

Barons subjugated and tranquillity established. Submission of Languedoc and territorial in(rease in the south. A iii, pt. ii, $16-7 ; B$ i, 32s; $C$ i, 320, 321; D) iv, 150-1; $11 \mathrm{ix}, 253$.

1236-1270

$A$ period of conspicuous progress, the only detracting foatures being the brief and unsuccessful soventle and righth crusades. More territory was acquired in the south of France. Security was everywhere maintained and private warfare suppressed. Population, commerce and industry increased. Many important public buildings were erected. $A$ iii, pt. ii, $52-9,82$; $B$ i, $333,336,339,314,317 ; C$ i, $337,340,342,344 ; \quad I I \mathrm{ix}, 253-5$. 
RULER

Philip III

Weak and ignorant. Controlled by others. Pious, docile, and virtuous. He led a monklike life. $A$ iii, pt. ii, $103 ; C$ i, 346 .

\section{Philip IV (The Fair)}

Accounts are too meagre. Generally considered cold and merciless, but some contemporaries picture him as pious, chaste, humble, and charitable. $A$ iii, pt. ii, $119,120,122-3 ; B$ i, 373 ; $C \mathrm{i}, 353,355,380,381,385$; II ix, 334 .

\section{Louis $\mathrm{X}$}

An obscure king, about whom little is known. Undoubtedly a eipher in the affairs of his time. Generally considered childish and pleasure-loving, leaving the affairs of state to others. A iii, pt ii, $119 ; C$ i, $382 ; H$ ix, 353.

\section{Philip V}

We know almost nothing concerning his ability or character. $A$ iii, pt. ii, 119.

\section{Charles IV The Fair}

Obscure, like his two brothers who preceded him. A iii, pt. ii, 119.

\section{Condition of Cocntry}

\section{0-1285}

Internal tranquillity continued. Catastrophe of the "Sicilian Vespers." French foreign influenco declined. Disastrous expedition against Aragon. $A$ iii, pt. ii, 113-7; $B$ i, 361 ; $C$ i, 346,347 , $349,351-2$.

\section{5-1314}

$\pm$

Some increase in territory, the most important of which was the eity of Lyons. Foreign prestige and influence considerable. France humbled the papal power and dictated in church affairs. Grinding taxation and much oppression. Coinage debased. Commeree injured. $A$ iii, pt. ii, 230-8 ; $B$ i, 362, 363, 364, 371, 372, 373, 376 ; $C \mathrm{i}, 355,358,373,381 ; E \mathrm{i}$, 181,$325 ; F$ i, $469 ; H$ ix, 333 , 334.

\section{4-1316}

Lawlessness and private warfare. Disastrous expedition against Flanders. Famine. $a$; $A$ iii, pt. ii, $309 ; B$ i, 377 ; $C$ i, 383 ; II $\mathrm{ix}, 353$.

\section{6-1322}

Short reign showing much confusion and persecution. $B$, $379 ; C$ i, 386; $H$ ix, 355.

\section{2-1328}

Brief and unimportant reign. Coinage again debased. $A$ iii, pt. ii, $238 ; B$ i, $380 ; C$ i, 387 . 


\section{RLLER}

\section{- $\quad$ Philip VI}

Incapable and headstrong. Violent, cruel, false, and heartless. He was, however, pious, and it is said that he loved his children. some generous impulses in his erratic nature. $n ; A$ ir, pt. i, 13, 14, s8; B i, 397; C i, 391, 393.

\section{- John II}

Rash, ignorant, obstinate, and incapahte. l'assionate, (ruel, self-indulgent. Fond of gatyety and luxury. $4 \mathrm{iv}$ pt. i, 92, 170: $B$ i. $397 ; C$ i, 423.

\section{- $\quad$ Charles V}

(Regent during the captivity of John II)

At this period he was between ninetern and twenty-three years of age. A foolish, indiffrent, and extravagent youth, eren cowardly, rolit, and dissombling. $A$ iv, pt. i, 117; $B$ i, 416; ('i, 435,448 ,

\section{- John II}

(Returned to France for a brief space and then went back into captivity in England. Charles $V$ again regent during John's absence. For characteristics see above.)

\section{Condition of Cocntry}

1328-1350

French defeat at Crécy. Commerce hampered. Finances badly managed. Blarek Death. A iv, pt. i, 16, 19-26, 5s-64, 73, 78, 87,$88 ; \quad B$ i, $352,383,390$, 392, 395, 396; ( $\mathrm{c}$ i, 393, 394, 397. $417,418,421,422 ; E$ ii, 217 , $220-66 ; F \mathrm{i}, 523$.

\section{$1350-1356$}

Evil days full of confusion and misery. Dof ant at Poitiers. France humiliated. Fiscal depletion. Exessive taxation. A is, pt. i, 9.5, (2, $100-2,105-8$; $B$ i, 397, 40.), 410, 417: $C$ i, 423,$434 ; E$ ii, $217,207-270$;

\section{0}

Nisery and despair continued. Jarquerie uprising and other arets of lawlessness. Humiliating Treaty of Brétigny. Further financial develine. France obliged to pay a large ransom for King John. b; $A$ iv, pt. i, $117-9,126-44,131,132,145-56$; $B$ i, 411, 414; ( i, 436, 444, 451; $E$ ii, 293, 309.

\section{$1360-1364$}

Deplorable ronclition of pestilence and disorder continued. The "free rompanies" ranged through the land. A iv, pt. i, $161-5 ; B$ i, 416, 417; $C$ i, 453; $F$ i, 523. 
RULER

$+\quad$ Charles V

In his mature years, clear, cold, prudent, patient, tenarious. Scholarly in his tastes. Pious, tolerant, benignant, chaste, and temperate. Somewhat unprineipled in his methods. $b ; A \mathrm{iv}$, pt. i, 182-90; $B$ i, 418; $C$ i, 435, $454,455,470-3 ; H \times$ x 66 .

\section{Condition of Cotntry}

1364-1380

Advance in general prosperity. Reëstablishment of order. Reforms in the army. Good fiscal policy. Territorial increase by diplomacy and arms. Regain of Ponthien, Querci, Rouergue, Limousin, Agénais, Poitou, Saintonge, a great part of Guyenne, Bretagne, and also part of Normandy. $b ; A$ iv, pt. i, $195-8,205,206,208,214-25$; $B$ i, 41s, 425, 42s, 429, 430, 431, 436 ; $C$ i, 455, 456, 463, 465, 466, 470,$472 ; E$ ii, 162,217 ; $F$ i, 637 .

\section{$1380-1388$}

Lawlessness, revolts, disorders. Financial diffenlties. $A$ iv, pt. i, $263,269,270-1,272,273-7 ; C$ i, $474,4 S 1,483-4 ; F$ i, $510-4$.

\section{Charles VI}

Weak and feeble mind. Became insane. Had temporarily lucid periods. Uncontrolled in his impulses and dissolute in his pleasures. His only merit was his good nature. $A$ iv, pt. i, $30 \mathrm{~s}$; C i, 477, 485-7, 489; $I I \times$ x $66-7$, $71-2$.

\section{Charles VII}

A selfish prince, fond of case and luxury. Mueh given to debauchery. There were poriods when he aroused himself to political work or to war, and then showed himself not without ability. II is judgment and prudenco

\section{8-1422}

French defcated at Agincourt. Rouen lost. Country torn asundor between rival factions. Excessive and burdensome taxation. $A$ iv, pt. i, 322-63, 368-70, $374-82 ; \quad B$ i, 45.) $457,459,46 i 2$, 464 ; $C \mathrm{i}, 485,486,489,491,493$, $494,507,509 ; F$ i, 521-2.

\section{2-1461} all France except Calais, Havre, and Guiness Castle. Financial reforms. Taxation regulated. Standing army organized and established. Lawlessness suppressed. The general misery
Expulsion of the English from 


\section{RULER}

wore always acute, until the last years of his life, when he was beset hy morbiel terrors. "Died of starvation, insane through fear that his son would poison him." a; $A$ iv, pt. ii, 20, 139, 22s-9; $B$ i, 449, 469, C i, 500, 546, 549 .

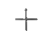

Louis XI

Ahle, rrafty, astute. Extremely ambitious and industrious. Cold, notoriousty unserupulous, suspirious, irasedible. Also at bad husband and father. A ir, pt. ii, 326, 41s; $B$ i, .74; ( $\mathrm{ii}, 28$.

\section{$+\quad$ Minority of Charles VIII}

Regency of Anne, daughter of Louis XI

Resembled ber father. Energetir and well informed. Firm, wise, and prudent. Haughty and austere. Sedtish and perhaps unscrupulons in her methods. $a$; $A \mathrm{ir}, p t$ ii, 42I, 437; $B \mathrm{i}, 576$, ist; (' ii, 103, 104.

\section{- Charles VIII}

Romantir imagination but inferior ability. Innorant, heedbess, self-willed. (iiven to delauchery. IIis only good trait was his aniable disposition. $a$; $b ; A \mathrm{v}, \mathrm{pt} . \mathrm{i}, 3 ; B$ i, $576 ; C$ ii, 118,129 .

\section{Condition of Cocntry}

continued, though somewhat alleviated. A iv, pt. ii, 53-8, $71,74,79-85, \quad 86-93, \quad 94-101$, 103-11, 126-8, 150-1, 233-5, 253-4, 317-9; $B$ i, 474, 478, 497, $502-4,50 \mathrm{~s}, 511-5 ; C$ i, 516 , $531, \quad 545-6,545-9, \quad 552 ; \quad F$ i, $535-41$.

$1461-1483$

$+$

Gain in strengtle and unity. Increase in territory. Maintenaners of law and order under a strong lands. Albance in rommeree and industry, especially in the towns. Loss of personal liberty.

\section{1}

Revolts suppressed. France triumphed over the rivalry of Austria. Allies defeated. Brittany forced to submission. Roform in the mode of election of the States-Gomeral. $a ; A$ iv, pt. ii, 42:3-4, 429, 433, 434; $B$ i, 583-6, 58s; $(?$ ii, 103, 104 .

\section{8}

Wasting wars in Italy, bringing no advantage to the French. Loss of ('ordagne, Roussillon, Burgundy and Artois. Commerce and industry continued good. $B \mathrm{i}, 582-4,586,592,593-$ $596 ; C$ ii, $129 ; k$ i, 554-5. 


\section{RULER}

\section{- or $\pm \quad$ Louis XII}

Intellect inferior or mediocre. Relied much on the judgment of others. His character is somewhat puzzling. Lazy and selfindulgent, yet well-intentioned. Noted for his good nature and humane qualities, yet cruel in warfare. Frivolous and debauched in younger years, simple and domestic in later life. $a ; b$; $A$ v, pt. i, $41-2 ; B$ i, 597 ; $C$ ii. $134,139$.

\section{\pm or + Francis I}

“'The king of culture." Brilliant, brave, ambitious and accomplished, but shallow. Wanting in judgment, resolution, aud force of character. Chivalrous, but selfish and self-indulgent. Lacking in sense of duty. $a ; b$; $A$ v, pt. ii, 43,97 ; $B$ i, $62 \mathrm{~s}$; $C$ ii, $169 ; \quad I$ xi, 50-1.

\section{$\pm \quad$ Henry II}

Of mediocre or inferior intelligence, dull, gloomy, and obstinate. He was perhaps honest and not evil in his intentions, but his character lacked strength and he was much under the influence of his aged mistress, Diana of Poitiers. Cruel at times. $a ; A$ v, pt. ii, 98, 124, 125; $B B$ i, 673 ; $C$ ii, 259, $260 ; H$ xi, 300 .
Condition of Country

\section{8-1515}

Weak foreign policy (Italian). Otherwise a period of progress. Improvement in the army. Finances brought into good order. Advance in agrieulture. Maintenance of law and order. Progress in the arts brought from ltaly, especially arehitecture. $b$; $A \mathrm{v}$, pt. i, $116 ; B$ i, 597, 614, 618, 619-24; $C$ ii, 137 ; $F$ ii, 6 ; $G$ ii, $229 ; H \times 224$.

\section{5-1547}

$\pm$

Wasted resources in unsuccessful foreign wars, though French territory remained intact. Commerce, and especially industry, increased. The middle classes on the whole prospered, though there was much disorder and discontont. Taxes were burdensome. Judicial reforms. Some loss of political liberty. $a ; b ; A \mathrm{v}$, pt. ii, $37,43,48,62,63,67,93$, 119,$120 ; B$ i, 628; $B B$ i, 693-5; $C$ ii, $169-71 ; F$ ii, $43 ; G$ ii, 229 ; $H$ xi, 211-2.

\section{7-1559}

$\pm$

Foreign wars, ending in the Peace of Câteau-Cambrésis, may be regarded as indecisive. Public finances declined. Industries advanced. $a ; A \mathrm{v}$, pt. ii, 137 , $175-8 ; \quad B B$ i, 673, 674, 681, 684; $C$ ii, $261 ; \quad F$ ii, 52, 153; $G$ ii, $230 ; H$ xi, 303. 
RULER

\section{- Minority of Francis II Regency divided}

Francis of Guise, - military affairs.

Charles of Ciuise, - rivil affairs.

Catherine de Medici, - title, nothing more.

\section{$+\quad$ Minority of Francis II}

Regency of Catherine de Medici

A remarliable and highly gifted woman. A eonsmombateschemer, unsermpulous in hor meills. Derojd of moral sense. $t ; .1$ vi, pt. i, 12 ; $B B$ ii, 22 ; (' ii, 294, 357.

\section{Charles IX}

Woak and varillating. Immoral and false. Disoased in mincl and lowly. ('haracter at once feethle and violent. BB ii, 32; ( $\mathrm{c}$ ii, 347, 35, 364; II xi, $31 \mathrm{~s}$.

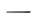

\section{Henry III}

Idle, rhildish, dreoitful, dissipatod. Is accorditorl with natural gifts, though he never put them to any usc. A vi, pt. i, $192-3,212-3 ; \quad B B$ ii, 42; $C$ ii, $366 ; \quad H$ xi, 322.
CONDITION OF COUNTRY

\section{$1559-1560$}

Violence, party lactions, civil and religious strife. A vi, pt. i, 25 et seq. ; $B B$ ii, 1-12; $C$ ii, 229; $G$ ii, 231-2.

\section{1}

A periol of roligious wars which injured merantile and industrial activity. Improvement in the findureial (onditions, and in the alministration of justies, 1 vi, pt. i, 5s, (i;), 104; $B B$ ii, $13,22,23 ; \quad F$ ii, 55,$56 ; \quad G$ ii, 231-2; 11 xi, 311.

\section{1-1574}

Religious wars continued, bringing ruin and desolation. Taxes heavy. Trade and industry derlined. a: A vi, pt. i, 12.5-52; $\quad$ ( ii, 3.)!), 361; $F$ ii, 5), 56,143 ; (i ii, 231-2; $H$ xi, 322.

\section{$1574-1589$}

Conditions similar to the preceding reign. Civil and religious wars. Bands of lawless arlenturers overrun the land. Public wealth squandered. Taxes beeome nore burdensome. Industry languisheel. $A$ vi, pt. i, 223-7; BB ii, 48, 50, 55-8; $C$ ii, 372, 394; $F$ ii, 143-7; $G$ ii, $231-2$. 
RULER

$+$

Henry IV

Brilliant gifts. Tremendous energy. Dauntless courage. Not highly educated but intellect was vigorous and sane. Eloquent as a speaker. By nature was fitted to be an arbitrary ruler and leader of men. Moral nature deficient. Selfish and sernsual and eraved exeitement. Ingratiating in his manner and popular with all elasses. $a ; A$ vi, pt. i, 306-8; $C$ ii, 441 ; $I I$ xi, 427.

\section{- Minority of Louis XIII Marie de Medici, Regent}

Incapable, capricious, irresolute. $b ; B B$ ii, 11s; $C$ iii, 45; also, Batiffol, "La vie intime d'une reine de France." Paris, 1906. English translation, 190s.

\section{- Minority of Louis XIII \\ De Luynes (non-royal) at the head of affairs}

\section{- $\quad$ Louis XIII}

Weak in will, childish in mind. Gloomy, ill-tempered, coldhearted, even cruel. I'sually described as chaste in his private life, but there is some doubt. $B B$ ii, 160; $C$ ii, 493.
Condition of Cocntry

1589-1610

First part of the reign devoted to the establishment of authority and order. Second part a period of exceptional advance. Increase in trade and industry. Improvement in agriculture. Financial reforms. Better roads, bridges, streets. Many publie buildings erected. Acquisition of new territory between Lyons and Geneva. $a ; A$ vi, pt. ii, 1-1S, 2:3-85; $B B$ ii, 97, 101-4, $106 ; C$ ii, $440,448,449 ; F$ ii, $151-86 ; G$ ii, $232-4$.

\section{0-1617}

Government in a condition of feebleness and indecision. Industry suffered. Treasury depleted. International prestige weakened. The burdens of taxation beeame increased. A vi, pt. ii, $171,181,190 ; B B$ ii, 11 s; $F$ ii, $186 ; \quad G$ ii, $234 ; \quad I I$ xii, 164 .

\section{7-1621}

Unsettled conditions continued. Unsucessful attack on the Huguenots in Languedoe. $B$ ii, 132.

\section{$1621-1643$}$$
\pm
$$

Aequisition of Ronssillon, Catalonia, and Sedan. France attained a position of international importance. But the finaneial condition was bat, and the masses were impoverished. There were internal disorders and conspiraeies, and loss of personal liberty in the growth of absolutism. $a$; $A$ vi, pt. ii, 412-34; $B B$ ii, 145, 146; $C$ iii, 49, 61-3; $F$ ii, 183, 188, 194-8, 201 ; $G$ ii, 235, 236-8. 
RULER

$\pm \quad$ Minority of Louis XIV

Anne of Austria, Regent

Ambitions and fromd. Her intelligenee was of a narrow sort, suitable only for intrigue. $A$ vii, pt. i, 4; C iii, \$J.

\section{Louis XIV}

Croat ambition and industry. A shrewal but narrow mind. Exressively valin, egentistiral, and selfish. Murle of a libertine but lawl serroral popmlar and amiablo qualities. 1 vii, pt. i, 119-3s; ('iii, 14s. $+\quad$ Minority of Louis XV Philip, Duke of Orleans, Regent

Fudowed with a hrilliant mind. Versatile and acoomplishod. Literary, soientific, and musical tastes. Idle and indifferent, with a dissolute moral nature. $a ; C$ iii, 36 t.

\section{Condition of Country}

1643-1661

Close of the Thirty Years' War, resulting in troatios of Westphalia and the Pyronees which were adrantageous to France. Considerable territorial gain. To offset this, the internal administration was weak. Poor commereial and agrieultural showing. Taxes increased. Financial resourees declined. A vii, pt. i, 16-24, 27-9, 59, 60, 65, 66, 81; $B B$ ii, $1679,170,192$; $C$ iii, 105; $F$ ii, 199; $G$ ii, 29!).

\section{1-1715}

First part of the reign markol by wise internal administration and brilliant victories over alien powers. The last part was a period of deeline. The country was imporerishod hy foreign wars. The interual administration was bad. The revoeation of the Edict of Nantes eost Franco murh in woalth and population. A vii, pt. i, 169-404; $B B$ ii, 195, 200-287; $C$ iii, 356, 424; $F$ ii, 204, 23.5, $2.54,366,420 ; \quad G$ ii, 239-245, $253 ; L 159$.

\section{5-1723} $\pm$

Diplomatic position weakened. Disorder in the finances. Trade and industry incrased. Improved roads and canals. Agricultural condition somewhat ameliorated. $B B$ ii, $346,349-54$, 367 ; $C$ iii, 388 ; $G$ ii, 253, 254, 256-65, 266. 


\section{RULER}

Minority of Louis XV

Louis, Duke of Bourbon, Regent

Dull and brutal, greedy and debauched. Completely under the influence of his mistress, the Marquise de Prie. $a ; b ; B B$ ii, 357 ; $C$ iii, 392 .

Minority of Louis XV Cardinal Fleury at the head of affairs

\section{- Louis XV}

Inferior capacity. Weak, indolent, timid, sensuous, and coldblooded. Notorious for his dissolute life. $a ; b ; c ; C$ ii, 388 .

\section{\pm or - Louis XVI}

Well meaning and endowed with fair intelligenee, but weak and vacillating. Obstinate and narrow-minded, and at the same time often under the influence of others. Had many private virtues. $b ; c ; B B$ ii, $434 ; C$ iii, 470 .
Condition of Country

\section{3-1726}

Diplomatic and financial management weak. Emigration of Huguenots. $B B$ ii, 357, 355-9; C iii, 392 .

Improvement in the finaneial condition. Trade and commerce revived. The general administration was not, howover, particularly definite and strong. Maritime power allowed to decliue. $B B$ ii, 360-2; $C$ iii, 393, 395-9; $G$ ii, 232 .

\section{1-1774}

Disastrous Seven Yaars' War. Loss of Canarla. Derline in commerce. Financial troubles. (Tnder excessive taxes the peasantry wore reduced to extreme misery. $B B$ ii, 360, 36i, 376, $381,386, \quad 387,394,395,401$, $402,403,409,411,414,416 ; C$ iii, 402, 467; $F$ ii, 549-59; $G$ ii, 2\$2-4; $L 161$.

\section{$1774-1793$}

First part of the reign shows some improvement in finanees, agriculture, and in international prestige. Last part of reign a horrible picture of general ruin, misery, and anarchy, terminating in the Revolution. $a ; B B$ ii, 435$437,438,443,444,448,479,464-$ $505 ; C$ iii, 470, 480, 4S5; .V 91. 


\section{BIBLIOGRAPHY FOR SPAIN}

a. Encyclopedia Britanniea. 9th and 11th editions.

A. Donhan, S. A. IIistory of Spain and Portugal. (Lardner's Cabinet (yclop.) 5 vols. London, 1832-1833.

[Out of date lut interesting to compare with modern opinions.]

B. Lafeevte yamalloa. Ilistoria General de España. 30 vols. $1850-1867,0 t+$

[Out of date for the medieval period.]

C. Burke, I. R. IIistory of Spain from the Earliest Times to the Death of Ferdinand the (atholie. 2 vols. London, 1895. CC. 2tl cel., 1900, rontains additional notes, and an intro. by M. A. S. Hunc.

D. Altamha y Crevea, R. Historia de España y de la eivilización española. Barcelona, 1900. D.D. 2 d ed., corregilla y aumentado. Bareolona, 19(0) -

E. Lenвke, F. W. Gesehiehte von Spanien. 7 vols, 1902.

F. Prescott, W. II. Fordinand and Isabella. 3 rols. Boston, 1857.

G. Hune, MI. A. S. Spain, its Greatness and Docay. Canbridge, Is!99.

II. Rosinerw St.-Hhtare, E. F. Historia d'Espagne. 14 rols. Paris, $1544-1569$.

J. Betr, A. Allgemeine (ieselichte des Telthandels. 3 vols. Wirn1, $1>60$.

K. LEA, II. (. A IIistory of the lnquisition in Spain. 4 vols. London and Xow York, 1906-1907.

L. Colmerro, Maxiel. Reyes ('hristianos deste Alonso VI hasta Alonso Xl an Castilla, Aragon, Navarra y Portugal. Madrid, $1 \$ 91$.

11. Catalina García, J. Cistilla y León durante los reinados de Podro I, Eurique II, Juan I y Enrique III. 2 rols. Madrid, $1 \$ 91-1893$.

\section{$+\quad$ Ferdinand I}

Exceptionally able and rirtuous. "One of the greatest and best princes.", a; $1 \mathrm{ii}, 151,152$, 155.
1035-1065

Garcia of Navarre defeated. Castile extended south of the Duero. Mohammedans also driven out of a large part of Portugal. Lcon acquired by marriage and well administered. Fueros granted. $a ; A$ ii, 135, 154, $155 ; \quad B$ iv, $18.5-211 ; E$ ii, 349 356. 
RULer

Sancho II.

Obseure

$+\quad$ Alfonso VI, the Brave

$A$ valiant and renowned warrior. "Very fierce and astute but a keeper of his word."' $a$; A ii, $160 ; E$ ii, 408.

\section{Urraca}

A notorious character. Violent, fickle, licentious, incapahle. a; $A$ ii, 160-164; $C$ i, 215; $L$ $2 \div, 33-34$.

\section{$+\quad$ Alfonso VII, the Emperor}

Brave, firm, and ambitious. Headstrong and immoderate. $a$; $B$ ii, $167 ; L 35$.

\section{Sancho III}

Characteristies unknown. A ii, 168.

- Minority of Alfonso VIII

(Control divided)

$+\quad$ Alfonso VIII, the Noble

Able, resolute, unselfish. Rightly called "noble." $a$; Ci, 218; E iv, 273, 291, 292.
Condition of Country

1065-1072

Obscure.

\section{2-1109}

"Dawn of Christian prosperity in Spain." Thirty-nine victories and two defeats. Galicia in northwest secured. Toledo captured. People received privileges. $a ; A$ ii, 158; $B$ i飞, 225, 414; $E$ ii, 373, 409.

1109-1126

Uninterrupted discord and party strife. Moors made inroads. $a$; $A$ ii, $160-164 ; C$ i, $215 ; \quad E$ iv, $35,36,37$; L 15-34.

1126-1157 +

Order restored, dominion greatly enlarged from the Tagus to the Sierra Morena. $a$; $A$ ii, 16.5-7; $B$ iv, 512-34; v 49, 82; C i, 216; E iv, 121, 123, 147, 149, $151 ; L 35-8$.

\section{7-1158} $\pm$

Brief and unimportant reign. Two minor victories.

\section{8-1168}

A period of anarchy and intrigues. A ii, 169-170; $E$ iv, $1 \$ 1$, et seq., $676 ; F$ i, $48 ; L 51-7$.

\section{8-1214}

Ruination of the Mohammedan Empire in the great battle at Las Navas de Tolosa, 1212. Peace at home. $a$; $A$ ii, 46,$48 ; B v, 127-235 ; C$ i, 219 ; $E$ iv, 255. 


\section{Reler}

Minority of Henry I

(Queen Berengaria regent for less than a year, then Alvaro Nuñez de Liara.)

\section{Ferdinand III, the Saint}

Distinguished for groat military talent and higoted religious zeal. A sincerefriend of learning. Siaid to have been just, amiable, and well-meaning. $a$; $A$ ii, 183 ; l) i, 370 .

\section{- Alfonso X, the Wise 1}

Impractiral and visionary. Fsperally elistinguished for his loarning and for his liturary and seientife arhioremonts. Energotir, restless, extremely ambitious. Well-meaning though arbitrary. A singular compound of wealiness and strungth. Is a ling he was wakk a; 1 ii, 1S3; 184,$190 ; C \mathrm{i}, 3.57$; $E$ ir, 67\%; $L \mathrm{i}, 112,114,119$.

\section{+ Sancho IV}

Brave, able. warlike, tyrannical. "Not a little rruel." Falso to his agreements. Had literary tastes and is considered to have writen two worlis in prose. a: I) vi, 309-16; $E \mathrm{ir}, 360 ; \quad I I \mathrm{iv}$, $30 \mathrm{~s} ; L \mathrm{i}, 139,145,151$.

I Would be + if all his mental traits the considered, see page 70 .

\section{Condition of Country}

\section{4-1217}

Civil wars. "The House of Lara became the scourge of the country." $A$ ii, $175-8 ; \quad E$ iv, $322-30$.

\section{7-1252}

Castile and Leon united. Great conquests of territory from the Mlohammedans. Corlova, the whole of Murcia, and the cities of Jaen and Serille taken. Beginnings of commercial activity. Cortes composed of the three states met in 1250. $a$; $A$ ii, 178-180, 152; $B$ v, 313$38 ; D$ i, 36s-71, 437 ; $E$ iv, 353, $368,379,391,404 ; J \mathrm{i}, 217-8$.

\section{$1252-1284$}

Much rivil discord and some conflict. No gain against the Mohammedans. Language, literature, seience, law, and commerce advanced. Bad fisaal poliey. $a ; A$ ii, 184, 185, 186; $B$ vi, 6-102; $C$ i, 290; $E$ iv, $443,676,677 ; L$ i, 111 , 114-9, 127-8.

\section{4-1295}

$\pm$

(Difficult to get the truth about this reign.) Family feuds and wasted resources. The king continually obliged to defend his throne. Successful over the pretenders and rebels. Tarifa in Africa taken 1292, otherwise no gain against the Moors. Commercial advance. $a ; A$ iii, 1946; $B$ vi, 315, 316; $C$ i, 291; $E$ iv, 629, 665, 666, 667, 670 ; $H$ iv , 308, 309, 314, 316, 318, 319; $J \mathrm{i}, 218$; $L \mathrm{i}, 139,145,146,151$. 
RULer

$+\quad$ Minority of Ferdinand IV Maria, Regent

Great qualities of heart and mind. Skilful as a diplomatist and politician. $B$ vi, $356 ; E \mathrm{v}$, $501 ; H$ iv, 324,$325 ; L$ i, 154 , 399-401.
Condition of Cocntry

1295-1302

$\pm$

Disasters and rebellions which, however, were surmounted in the end. Foreign enemies, especially Aragon, frustrated. "Hermandad" (association of free citizens) founded. $a ; A$ ii, 196-9; $B$ vi, $360,364,365,366 ; C$ i, 293; $E$ v, 77, 79, 85, 89, 95; $H$ iv, 323,325 .

\section{- $\quad$ Ferdinand IV}

Died aged twenty-six. Weak and inferior capacity. His moral traits are difficult to judge. Some say vindictive, passionate, and unjust, others the opposite. $a$; $C \mathrm{i}, 293$; $H 336$; $L \mathrm{i}, 178$.

\section{Minority of Alfonso XI}

(Regency divided).

$+$

\section{Alfonso XI}

Hard, brutal, licentious, tyrannical, but a just and rigorous ruler and warrior. His enemies are said to have honoured him. $a ; A$ ii, $86 ; C C$ i, 295-300; $D$ i, $575-6$.

\section{$\pm \quad$ Peter the Cruel}

Bold, enterprising, not without ability. Lacking in juclgment. Ambitious, tyrannical, and obstinate. Generally con-

\section{2-1312}

Interminable dissensions and revolts. Gibraltar taken from the Moors, 1309. a; $A$ ii, 196, 197,$200 ; B$ vi, 370, 371, 37t; $C$ i, 205, 343; $E$ iv, 115-6, 121-3.

\section{2-1324}

Civil wars and desolation. a ; $A$ ii, 205; $C$ i, 296; $E$ v, 145 , $153 ;$ II iv, 402-3, v, 106; $L \mathrm{i}$, 400-1.

\section{$1324-1350$}

A troubled reign, yet castile at Salado over the Moors, 1340. Algeria eonquered. Cortes increased in importance. $A$ ii, 20.5 ; C $\mathrm{i}, 296 ; D \mathrm{i}, 575-6 ; E \mathrm{v}, 187$; II iv, 433-9, v, 106.

\section{0-1369}

$A$ period of turbulenee. Wars with Aragon. Civil wal waged between Peter and Honry for the throne. No marked advance grew in unity, importanes, and political liberty. Great rictory 
RULER

sidered the incarnation of cruelty and vice. ${ }^{l} B$ vii, $216-30 s ; E$ v, 500,$501 ; H$ iv, 445 .

\section{$+\quad$ Henry II}

Ambitious, forceful, cruel, and tyramical. ls saitl to have shown elemency at times. $a$; $A$ ii, 232,$233 ; E$ iv, 30,$31 ; I I \mathrm{v}$, 107.

\section{John I ${ }^{2}$}

Weak in body and mind. Mild and amiable. Just and generous. $A$ ii, $240 ; B$ vii, 354; $I I$ r, 150 .

\section{- Minority of Henry III Regency in a Council}

\section{$+\quad$ Henry III}

Wise, resolute, and just. Beloved by his people. a; $A$ ii, 243; $B$ ix, 9; $E$ vi, 10s; $H$ v, 160.

\section{Minority of John II}

\section{Ferdinand I of Aragon, Regent}

Pruclent and able. An excellent chararter. a; 1 ii, 244 ; $B$ viii, 167-s; C 2, 353-4. E vi, $197 ; \quad I I \mathrm{v}, 212-3$.
Condition of Country

or decline. $a ; A$ ii, 213-24;

$C$ i, 302, 312; $D$ i, 576-585. $E$

v, 325-33; II iv, 473, v 106.

\section{9-1379}

Kingdom pacified and enemies subdued. Somre progress in jurisprudence. $a ; A$ ii, 234; $C$ i, $324 ; E$ vi, 30, 31; $I I$ v, 106, 109,$112 ; 1 / \mathrm{ii}, 3-146$.

\section{0}

Castile defeated by Portugal in the important battle of Aljularota. In other encounters with the Portuguese the Spaniards were generally unsuceessful. a : $A$ ii, $237 ; D$ i , $587 ; .14$ ii, 203420 .

\section{$1390-1400$}

Civil wars without security for person or property. $a ; A \mathrm{ii}$, $241 ; B$ viii, $37,42,43 ; E$ vi, 83 ; II v, 152, 153, 154.

\section{6}

$+$

Tranquillity restored. Diplomatic sueeessin. Lexislature advances. $a ; A$ ii, $243 ; C$ i, 328, $336 ; H \mathrm{v}, 158$.

\section{6}

Law and order maintained. Fortress of Antequera taken from the Noors. $a ; A$ ii, $244 ; B$ viii, $167,168, \mathrm{ix}, 14$.

1 There has been an attempt to exonerate Peter from the charges of mad cruelty with which his name has always been associated, hut it cannot be said that most writers have been won over from the older view.

Tickuor, History of Spanish Literature i, 165 ; Schirmacher, v, 500 ; Lafuente, vii, 30s; and Dunham, ii, 230; give an extended discussion of the question of Pedro's cruelty.

2 Virtues graded wrongly" at (3) in "Heredity in Royalty." 
RULER

Minority of John II

(Catharine, Regent)

Regeney in a Council.

\section{John II}

Weak, almost an imbecile. Pleasure loving and indolent. Amiable and had some refined tastes. $a ; A$ ii, 245,$257 ; B$ viii, $168 ; F 1-5$.
Henry IV

Extremely weak-minded, indolent, cowardly, and debauched. "Good-hearted." a; 1 ii, 266 ; $B$ viii, 496,$497 ; F \mathrm{i}, 164$.

\section{$+\quad$ Isabella}

Remarkable ability and noble virtues. Prudent, resolute, and dignified. Sympathetic, unselfish, and modest. The only imputation against her is excessive religious zeal. $a ; A$ ii, 282; $E$ vii, $358 ; F$ iii, 184-205.

Condition of Country

1416-1418

Rival faetions and diseord again extend their influence throughout the kingdom. $B$ ii, 245 .

\section{8-1454}

Deplorable condition of affairs. Anarchy and disorder. The Moors raraged the country again. Spain, however, gained in riches (Burke). $a ; A$ ii, 24.5-57; $B$ viii, 168,425 , ix, 97 ; $C$ i, 357 ; $E$ vi, 205, 207-10, 212-367; $F$ i, 5-8.

Rebellion, disorders, disasters, decline. $a ; A$ ii, 2-5-266; $B$ viii, 497 , ix, $9 S ; E$ vi, 438,439 , $461,477-9,537$.

1474-1479
Order established. Reforms
in judiciary, finance, and legis-
ation. $b: A$ ii, 269-270; $B$ ix,
$137-40,146,163,164-96 ; E$ vi,
$587,558,589,595,601,603 ; H$
v, 409-419-425, 433-7.
v, 409-419-425, 433-7. 


\section{ARAGON}

\pm or $t \quad$ Ramiro I

Bold, ambitious, and enterprising. Rather obseure. $a$; $C \mathrm{i}, 198$.

\section{$+\quad$ Sancho I (Ramiro)}

Restless and enterprising. A sucessful warrior. A iii, 80 ; $E$ ii, 335.

\section{$+\quad$ Peter I}

As brave and enterprising as his father. Noted for his justice and chivalry. $B$ iv, $449 ; H$ iii, 356.

$+\quad$ Alfonso I, the Battler

Brilliant military leater. Bold and relentless. Accused of duplicity and eruelty. $a ; A$ iii, 83 ;

$+\quad$ Ramiro II (The Monk)

A man of little account. Lacked ambition and courage. Said to have been modest and well-meaning. $B$ iv, 538; $C$ i, 201; $E$ iii, 27.
1035-1063

Aragon consolidated, began as a separate kingdom within narrow confines. Area and importance increased. $a ; A$ iii, $79 ; B$ iv, 244-5; $C$ i, $198 ; E$ ii, 332-5; $H$ iii, 295.

\section{3-1094}

Conquests from the Mohammedans. Area extended as far as the Ebro. $A$ iii, 80 ; $C$ i, 198 ; $E$ ii, 335.

\section{4-1104}

Important conquest of the city of Huesca. $a ; A$ iii, $83 ; B$ iv, $449 ; C$ i, 198 ; $I I$ iii, 356 ; $I$ ii, 341 .

\section{4-1134}

More territory eonquered including the cities of Tudela, Saragossa, Tarragona, Catalonia, and most of the country south of the Ebro. $a$; $A$ iii, 84, 87; $C$ i, $190 ; D$ i, 371-2; $E$ iii, 620 ; II iii, 371, 410.

\section{4-1137}

Dangers and difficulties. Navarre immediately threw off the Aragonese yoke. Castile won best cities from Aragon. $B$ iv, $538 ; E$ iii, 28,$29 ; H$ iii, $410-2$. 
RULER

\section{$+\quad$ Raymond Berenger}

Consort of Petronilla. He had a superior character. Intelligent, determined. Excellent moral traits. $A$ iii, $90 ; C$ i, $214 ; D$ i, $373 ; G$ iii, 42, 43.

\section{$+\quad$ Alfonso II}

Able, ambitious, and accomplished. A patron of the troubadours, and author of poems in Provençal. $a ; A$ iii, $91 ; C$ i, $217 ; D$ i, $374 ; E$ iii, 53.

\section{$\pm \quad$ Peter II}

Mediocre in ability. Not particularly firm. Frank, generous, impulsive, sensuous. Evinced courage as a warrior on several occasions. $A$ iii, 91-94; $C ; E$ iii, $70 ; H$ iv, 55 .

\section{Minority of James I (Regency divided)}

\section{$+\quad$ James I, the Conqueror}

A bold, powerful leader of men. Fiery, eruel, inexorable, licentious. Impulsive and magnani-

\section{CONDITION OF COUNTRY}

1137-1162

Dominions consolidated and united with Catalonia. Three more cities taken from the infidels. 1153-1162 were peaceful and prosperous years. $A$ iii, 90 ; $B$ iv, 555,$556 ; C$ i, 202; $D$ i, $373 ; E$ iii, 43, 208.

\section{2-1196}

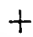

Several fortresses taken south of the Ebro. Prestige in foreign affairs enhanced. Aragon relieved from homage to Castile. First Cortes 1163, at which the Third Estate was represented, called by Queen $\mathrm{Pe}$ tronilla on the death of her husband. $A$ iii, $91 ; B \mathrm{v}, 155 ; D$ i, $374 ; E$ iii, 53,54 .

\section{6-1213} $+$

No special prosperity or progress. One fort taken from the Moors. Aragon assisted Castilo in the great and successful battle of Las Navas de Tolosa. Country impoverished through tributes to the Pope. $a ; A$ iii, 94; $B \mathrm{v}, 188,190 ; C \mathrm{i}, 217,218$; $E$ iii, $70-1 ; H$ iv, 48,56 .

\section{3-1228}

Internal disturbances. Deeline in law and order. $A$ iii, 97 ; $B$ v $, 385,387$; $E$ iii, 72,82 .

\section{8-1276}

Important conquest of Valencia, Murcia, and the Balearic Isles. Improvements in juris- 
RULer

mous on occasions. Iligh literary talent. $a ; A$ iii, $104 ; B$ iii, 76 ; $C \mathrm{i}, 257 ; D \mathrm{i}, 353$.

\section{$+\quad$ Peter III, the Great}

Able warrior and politician. Ambitious, enterprising, just, and mereiful. $a ; B$ vi, $191 ; C \mathrm{i}, 276$, $280,2 \$ 3 ; k \mathrm{i}, 100$.

\section{Alfonso III, the Magnificent}

Twenty-one years old when he eame upon the throne. Died aged twenty-six. Material is lacking for the propere estimation of his reharateder, lout he appears to have been a medioce, perhaps a feeble, and cortainly a prodigal prince. Ev vi, 25, 2.56; $I I \mathrm{r}, 352$.

for \pm James II. the Justice

Brave, rigilant, diplomatic. Magnanimons: and benovolent, but debaurhed. $a ; A$ iii, 120, 121,$123 ; B$ เі, $426 ; \quad I 1 \mathrm{iv}, 386$; $L \mathrm{i}, 222$.

\section{- Alfonso IV, the Benign}

Feeble in energy and mind. Good-hearted. Fond of his people. On several oreasions perhaps dishonorable and treacherous. A iii, $126 ; B$ vi, 454; $H$ iv, 348, 390, 395, 396, 397 .

\section{Condition of Codntry}

prudence. Increase in riches and trade in this and sueceeding reign. $a ; A \mathrm{iii}, 10.) ; B \mathrm{v}, 382$; D i, 379-383; $E$ iii, 140, 141, 142; F i, 110 .

\section{6-1285}

Sicily enqquered. Mialta reduced. French invasion re pulsed. Privilegio General the Magna (harta of Aragon) granted. $A$ iii, $109 ; B$ vi. 107, 112, 129 $136,180-6 ; \quad(+\mathrm{i}, 283 ; F \mathrm{i}, 100$, $110 ; J$ i, 21. i.

\[ 2851291 \quad \pm \text { or }+ \]
Conditions remianed station-
ary. Politioal intrignes. No spe-
(ial advance exeret in the power
of the great vassals and com-
munes. A iii, $116 ; H \mathrm{v}, 352 ; L \mathrm{i}$,
$217-20$.

1291-1327

Gain of sovereignty over Corsica and Sardinia. Successes in the Moditerranean. Peace and strength at home, especially in legislation. Siroily abandoned. $a$; $A$ iii, 121; $B$ vi, 409; $C$ i, 286; $E \vee 74 ; \quad H$ iv, 384, 386; $L$ i, $220-2$.

\section{7-1336}

An insignificant reign. No advance. Commercesuffered somewhat from the attacks of the Genoese. $a ; A$ iii, $126 ; B$ vi, $446,451,454 ; C$ i, 314; $I I$ iv, 390-2, :395, 397 . 
Ruler

$+\quad$ Peter IV, the Ceremonious

Active, sagacious, inflexible, but deceitful, violent, perverse, and extremely cruel. $A$ iii, 143 ; $144 ; B$ vii, 80,$142 ; C$ i, 314 , $316 ; H$ iv, $396, \mathrm{v}, 1,52-3$.

\section{- John I, the Careless}

Weak, indolent, and pleasureloving. A voluptuary. Fond of hunting, music, and poetry. $a$; $A$ iii, $146 ; B$ vii, 410,$420 ; C$ i, 317 .

\section{\pm Martin, the Humane}

Of about average raparity. Good soldier, noted for benignity and justice. $A$ iii, 147,$150 ; B$ vii, $447 ; H$ v, $176 ; E$ vi, 175.

- Interregnum

$+\quad$ Ferdinand I, the Just

Vigorous, sagacious, moderate and just. $a ; A$ iii, $155 ; E$ vi, $197 ; H \mathrm{v}, 212-3$.

\section{Condition of Country}

1336-1387

No marked arlvance or decline. Wars both civil and foreign, leading to disasters as well as glories. The chief gain was legislative. The ancient privileges were confirmed, and constitutional liberty rë̈stablished under a firm eentral power. $a$; $A$ iii, 127-14; $B$ vii, 61, 71, 84,$142 ; C \mathrm{i}, 315 ; F \mathrm{i}, 94 ; H \mathrm{iv}$, $47 \mathrm{~S}, \mathrm{~V}, \mathrm{I}$.

1387-1395

Short and unimportant reign. "Not without its troubles." Efforts to suppress insurrections in Sardinia and sicily were but partly suceessful. Mueh discontent prevailed. $a ; A$ iii, $145-6$; $B$ vii, $413-20 ; C$ i, 318 ; $E$ vi, 170 .

\section{5-1410}

Advance, offset by internal disorders. Sicily and Sardinia peaceful. Adrance in the power of the justiciary. A iii, 147-50; $B$ vii, 429,$432 ; E$ vi, 174 , 175,$176 ; H \mathrm{v}, 176,183$.

\section{0-1412}

Civil wars and clisorders. A iii, $150-2 ; B$ viii, $115-20 ; H \mathrm{v}$, $189-97,202$.

\section{2-1416}

Peace and order estahlished. $A$ iii, 155-6: $B$ viii, 134,147 , $50 \overline{5} ; \quad I I \mathrm{v}, 200,202,206$. 


\section{Ruler}

\pm or + Alfonso $\mathrm{V}$, the Magnanimous

Firm, able, generous, humane. The only charge against his character is that he was licentious and at times unduly severe; but his virtues receive more praise than censure. $a$; A iii, 157-8; $B$ viii, $354 ; C$ i, $348 ; H$ v, 27980.

\section{$+\quad$ John II}

Ambitious, enterprising and able. One of the shrewdest princes of his time. Ferocious temper, tyrannical, licentious. $a ; B$ viii, 421-2; $C$ i, 354; $F$ i, $175 ; H \mathrm{v}, 390$.

Ferdinand and Isabella

$+\quad$ Isabella (see Castile)

+ Ferdinand V, the Catholic

Brave, active, ambitious. One of the shrewdest statesmen of his century. Impartial, temperate, and economical in his labits; but is eharged with duplicity, bigotry, selfishness, and lack of gratitude. a; $A$ ii, 283; $E$ vii, 685-6; $H$ 183, $237-40$.

+ Ferdinand V, the Catholic (Regent)

(Vide supra.)

\section{Condition of Country}

1416-1458

No marked advance or decline. Wars in Italy occupied most of the reign. Conquest of Naples, which proved a vain glory. Internal order well maintained. Commerce injured. $a$; $A$ iii, 158,$165 ; \quad B$ viii, 355 ; $H$ v, 276,278 ; $J$ i, 216.

\section{8-1479}

Wars and insurrections in Catalonia, in which the king triumphed in the end. Commerce and industry made a ereditable showing during these last two reigns. $a ; A$ iii, $165 ; B$ viii, 376-9, $387,417,5333-5,543 ; H \mathrm{v}$, $367,368,373,387$; F i, 55.

\section{9-1504}

Insurrection subdued. Good order established. Conquest of Granada. Final subjugation of the Mohammedans, who were either converted or driven out. Reforms in the government. Increased prosperity of the country. Beginnings of colonial expansion. Growth of commerce. $a$; $A$ ii, 272, 273, 278, 279, xi, 48, $68, \mathrm{xv}, 10 ; E$ vii, 203, 204; $H$ vi, $165 ; J$ ii, 141.

\section{4-1506}

Turbulent cpoch settling the regency. $A$ ii, 285-8; $B \mathrm{x}$, 276-7; $H$ v, $175 ; J$ ii, 143. 
RULER

\section{- Philip I, the Handsome}

Weak, insignificant, indolent. A profligate devoted to pleasure. Gentle and pacific. $B \times 300$; $C$ ii, 247; $F$ iii, 256-7; $H$ vi, $H$ vi, 183, 184.

183.

+ Ferdinand V, the Catholic

(Regent)

(Vide supra.)

\section{- Regency for Joanna ${ }^{1}$} (Cardinal Ximenes, Regent)

A very able man. 269.
Condition of Country 1506 (for two months)

Disorders and discontent. Depletion of the public revenues. $B \mathrm{x}, 299-300$; $C$ ii, 247, 249;

1506-1516

Insurrections quelled. Conquest of Oran, Burgia, Algiers, Tunis, and Navarre. Extension of commerce. Kingdom raised again to importance. Agricultural improvement. $a ; A$ ii, $288-90 ; B$ x, 395, 415-6; $E$ vii, $685 ; H$ vi, 203, 207, 267,

$$
\text { 1516-1517 } \pm \text { or }+
$$

Order maintained. Wars successful in Navarre, disastrous in Africa. $B \mathrm{x}, 446,447,458,461$, 462,$471 ; C$ ii, 289 ; $H$ vi, 292 , $296,297$.

\section{+ Charles V (I), the Emperor}

1517-1556 \pm or +

Inordinately ambitious. Was accomplished, restless, crafty, cold, and selfish. Gloomy and eccentric in his latter years. $a$; $\mathrm{H}$ vii, 206-12; also E. Armstrong, "The Emperor Charles V., 2 vols. London, 1902.

In this and the succeeding reign Spain reached her apogee of outward splendor. On the credit side we may mention the conquest of Mexico, Peru, Milan, and Tunis, and the increase of money. On the debit side this is perhaps offset by the cost of foreign wars and the loss of popular liberty. $a ; A \mathrm{v}, 5,9,11$, $23,30,33,263 ; B$ xi, 110-24, 444 , xii, $122,128, \mathrm{xv}, 75,84,96$; $J$ ii, 144, 145.

${ }^{1}$ Non-royal and divided regencies are taken at minus. 


\section{RULER \\ \pm or + \\ Philip II}

A diffieult rharaeter to grade. Mentally he was ambitious, industrious in petty details, but a procrastinator, and lacking in judgment and breadth of view. lie was gloons, morose, suspirious, despetire jealous, and dissimulating, and by many ronsidered aruel. llis temperance is offset by his extravagant expernetitures. Jlis rhict virtue appears 10 have been his patience. $\left.a ; c ; a] s_{1}\right)$ Wenz(lhurger, " (it'seh. Nioderlancle," ii, 7 -10, and Martin Hume, " P'hilip II."

\section{- $\quad$ Philip III}

Weak, indolent. with a tendeney to melaneholia. Pious and wellmeanine, but plasure-loving. cxtravagant, and areless. $a: \quad r$ 11: Also Watson, "History of I'hilip tII."
Condition of Country

1556-1598 \pm or +

Height of outward splendor and beginnings of internal decay. Acquisition of Portugal. Spain lost control of Netherlands. Riches and extravagance of the nobility. Depletion of national funds. Povcrty of the people. Agriculture, industry, and commere declined. Destruction of the Armada. $a$; $A \mathrm{v}, 58,61,62: B$ xiii, 45, 117\&, xv, 136-9); $/ 1$ viii, 328, 381, ix, $150,202,257,325,373, x$, $355 ; J$ ii, $146-8$; $K 190$.

\section{8-1621}

Rapid decline. Poverty and depopulation. Rivalry and intrigues in the court. Independenere of the Netherlands acknowlalgerl. Expulsion of the industrious Moriscoes. $a ; A \mathrm{v}, 87$, 89,$90 ; 13$ xง, 35.5, 393, 484-5, $496 ; \quad I I \mathrm{x}, 33 \mathrm{3}, 395,471,486$, 488,$505 ; J$ ii, $148-9$.

\section{1-1665}

- or $\pm \quad$ Philip IV

Indolent, wak rharaeter. Govemed hy olivarez. Had a fair understanding and eultivated tastes. Luxurious and lirentious. a; Also Don A. Cánovas del Castillo, "Estudios del reinado te Felipe IV."
Continued derline in agrieulture, commeree, and the mechanic arts. Further depletion of finanees. Loss of Portugal and the island of Janaica. $a ; A \mathrm{v}$, 92, 93, 98, 99, 276; $B$ xvi, 105, chap. 7 , xvii, 355, 359, 370-83; $H$ xi, 17, 65, 271, 273; $J$ ii, 149. 


\section{RULER}

\section{- Minority of Charles II}

(Mary Anne, Queen of Philip IV, Regent)

Petty intriguer. Her private life was pure. Several others shared in the control of the government.

\section{- $\quad$ Charles II}

An imbecile. Virtues negative. $a$; $G$ 284-317.

\section{- $\quad$ Philip V}

Indolent and sensuous. Was well-meaning and good-natured, but became melancholy and finally insane. $a ; B$ xix, 252253; $H$ xii, $451,454$.

\section{\pm or $-\quad$ Ferdinand VI}

Of mediocre or inferior capacity, but prudent, firm, and upright. Became insane. $a ; B$ xix, 378, 387, 390; G 350, 359, 371 ; $H$ xii, 451 .

\section{$+\quad$ Charles III}

Enlightened, efficient, just, and sincere. Not brilliant, but had a very well-balanced mind. $a ; G$ 392-411.

\section{Condition of Codntry}

\section{5-1679}

Decline continued. Intrigues. Rebellion in Sicily. Loss of Franche-Comté and fourteen fortresses in Flanders. $a ; A \mathrm{v}$, 103-5; $B$ xvii, 101-2, 386; $H$ xi, 275, 291, 297-9.

\section{9-1700}

Misery, poverty, hunger, disorders, decline, especially in agriculture, finances, and strength of the army. $a ; A$ v, 277; $B$ xvii, $136-7,170,186-7,234,402-$ 412,$426 ; H \times \mathrm{xi}, 379,381,451$, $485-6 ; J$ ii, 158.

\section{0-1745}

Improvement in commerce, industry, army, and navy. Territorial losses, Gilbraltar and Minorea. $a ; A \mathrm{v}, 141,164$, 27S-81; $B$ xix, 235, 238, 243, 245 ; $H$ xii, $319,435$.

\section{5-1759}

Improvement in agriculture, commerce, and industry. Financial reforms. $A \mathrm{v}, 166,167,283$; $B$ xix, 340-7, 378; $H$ xii, 491, 492,500 .

\section{9-1788}

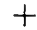

Continued improvement in financial and commercial conditions, including agriculture and the useful arts. Efficieney of the army raised. Foreign policy not particularly successful. A v, 170, $171,175,181,283,284 ; B \mathrm{xx}$, 360-80; $H$ xiii, chap. III, 210224. 


\section{BIBLIOGRAPHY FOR PORTUGAL}

a. Encyclopædia Britannica. 9th and 11th editions.

$b$. La grande encyclopédie.

A. Stephens, H. M. History of Portugal. Story of the Nations Series. London, 1891.

B. McMurdo, Edward. The History of Portugal. 3 vols. London, 1888-1889.

Wol. I is nothing more than an abridged translation of Herculano's Historia de Portugal, though Herculano's name is not mentioned. Vols. 2 and 3 are taken from Pinheiro Chagas and others.]

C. Dunham, S. A. History of Spain and Portugal. 5 vols. London, 1832-33.

[Out of date, but interesting to compare with modern opinions.]

D. Herculano, A. Historia de Portugal. 4 vols. Lisbon, 1853.

[The standard authority for the early period, but closes with the year 1279.]

E. Schatfer, H. Geschichte von Portugal. 4 vols. Hamburg, 1836-52. EE. Same, French Translation. Paris, 1846.

$F$. Oliveira Martins, J. P. Historia de Portugal. 2 vols. Lisboa, 1894-95.

[Brilliant and sketchy. His writings show much independence of judgment and sound scholarship.]

G. Pinheiro Chagas, Manuel. Historia de Portugal. 8 vols. Lisboa, 1899.

H. Gava Barros, Henrique da. Historia da administração Publica em Portugal. 2 vols. Lisboa, 1885-96.

[Based on original sources.]

$J$. Fonseca Benevides, Francisco da. Rainhas de Portugal. 2 vols. Lisboa, 1S78-79.

$K$. Herctuavo, A. Historia da origem e do estabelecimento da inquisição em Portugal. 3 vols. Lisboa, 1864.

L. Sousa Silya Costa Lobo, A. De. Historia da sociedade em Portugal. Lisboa, 1903.

M. Oliveira Martins, J. P. Os filhos de João I. 2 vols. Lisboa, 1901.

N. Coelho Rocha, A. Ensaio sobre a historia do governo e da legislaião de Portugal. Coimbra, 1843.

P. JAYNe, K. G. Vaseo da Gama and his Successors. London, 1910.

Q. Beazley, C. R. Prince Henry the Navigator. The Hero of Portugal and of Modern Discovery. London and New York, 1908. 
RULER

$+\quad$ Henry of Burgundy

Count of Portugal

Brave, brilliant, enterprising. Not much known about his personal traits. $A 21 ; C$ iii, 178 ; $D$ i, 202-203, 232.

\section{$+$}

Theresa

Very ambitious, able, and energetic. Politically astute. Her moral character has been the subject of debate. Probably her virtues were not equal to her talents. $a ; A 21 ; D$ i, 232, 234-235, 289, 475-480; $F$ i, 6064.

\section{$+$}

\section{Alfonso I}

Brave, tenacious, and enterprising. Great enthusiasm and love of glory. Charged with treachery and cruelty. $a ; A$ 34, 35-59; $D$ i, 299, 300, 304; F i, $78 ; M$ i, 37 .

\section{Sancho I}

Able administrator, extremely energetic. Violent temper. $A 69$; $B$ i, 242, 296-297, 298; $C$ iii, 189; G i, 43, 46.

\section{$\pm \quad$ Alfonso II}

Able and vigorous, but harsh and tyrannical. More of a schemer than a warrior. Avaricious and grasping. $a ; A$ 70-74; $B \mathrm{i}, 31$, $357 ; C$ iii, $190-193 ; D$ ii, 186 ; $F$ i, $98 ; G$ i, 52, 58-59.
Condition of Country

1094-1114

Founded the family prestige. $B \mathrm{i}, 129-130$; $C$ iii, 178 ; $D \mathrm{i}$, 231-2.

\section{4-1139 \\ Dominions were built up and vastly strengthened. $a ; A 28$, 29,31 ; $B$ i, 132-133, 145-148; $C$ iii, $179 ; D$ i, 246-247, 289-290.}

\section{$+$}

Portugal founded as a kingdom (in status if not in name) and territory expanded to the south, as far as the Tagus. $A 37,39$, 40,$53 ; B$ i, $150,152,172,217$; $C$ iii, 180, 185, 188.

\section{5-1211}

Further advance through internal improvements. Charters granted to many cities. Agriculture and immigration fostered. $a ; A 60-70 ; B$ i, 275, 297; $G \mathrm{i}, 38-46$.

\section{1-1223}

$\pm$

Financial gains. Constitutional advance. First Portuguese Cortes. Royal power increased at the expense of the nobles. $a$; $A$ 70-74; $B$ i, 357, 358; $C$ iii, 191, 192; $H$ ii, chaps. IV-VII ; $F$ i, 98 ; $G$ ii, 59, 250-251. 


\section{RULER \\ Minority of Sancho II}

No one royal person in control.

\section{$\pm \quad$ Sancho II}

A brave and dashing soldier; but indolent when not at war. Lacked administrative ability. Became sensual and unpopular. Material for estimating Sancho II is meagre and the whole picture of his reign is colored hy party prejudice. it $7 \mathrm{~s} ; C$ iii, $194 ; D$ ii, $340-341$.

\section{$+\quad$ Alfonso III}

A great warrior and statesman, but an unprincipled tyrant. $a$; $A$ so, S1; $B$ i, 453, 474; $G$ i, SS-9.

\section{$+\quad$ Diniz}

Called "the Laborer." Great abilities. Ardent, sensuous, somewhat cruel. A patron of literature and was himself a poct. $a$; $A$ S5, 86 ; $B$ ii, 15 ; $C$ iii, 168, 169 , $171 ; G \mathrm{i}, 164,174$.
Condition of Country

1223-1227

Obscure period. Probably much anarchy during the first three years. Peace made with Pope Houricus III and conquest of Elvas. $a ; A 7+75 ; D$ ii, 263$87 ; G$ j, 59-64.

1227-1245 - or \pm

Much territory taken from the Moors. The reign ended in intrigues and eivil war. The king deposed by the clerical party headed by Alfonso. $A$ 75, 79; $C$ iii, 193-195; $D$ ii, livro $\mathrm{V}$; $G \mathrm{i}, 64-\mathrm{ss}$.

1245-1279

Conquest of Algarve. General prosperity. Commerce and industry increased. Municipal organization became more extended, and Cortes more representative. Rebellion of Deniz (1277-1279). $a ; A, 80-83 ; B$ i, 472-474; $C$ iii, 198-199; $G$ i, $251 ; H$ ii, chaps. IV-VII, X ; N 85.

\section{9-1325}

Country made great advances, especially in agriculture and administration of justice. Navy established. Commercial treaty with England (1:294). Several rebellions occurred, but these were brief and comparatively harmless. $a ; A$ S6, 87, 89; $B$ i, $472,473,474 ; \quad C$ iii, 200, 201, $204 ; \quad F$ i, 126-127, 173-174; $H$ ii, chap. $\mathrm{X}$, also page 255 . 
ROLER

$+\quad$ Alfonso IV, the Brave

Able, but cruel and tyrannical. Is accounted chaste. $A$ 91-97; $B$ ii, 198; $G$ i, 248-250.

\section{$+\quad$ Peter the Severe}

A wise, despotic, and severely just ruler. A picturesque character. Popular in spite of his faults. Strong in his hatred and spontaneous in his love. $a ; A$ 99,$100 ; F$ i, $101-10 ; G$ i, 280 .

\section{- $\quad$ Ferdinand I}

Naturally bright, affable, and imaginative, but was weak, indecisive, indolent, frivolous, and dishonourable; lacked courage, failed to keep his faith. Came under the influence of the notorious Leonora Telles. $a ; A$ 101103; $B$ ii, 211; $C$ ii, 207; $F$ i, 128-41; $H$ ii, 259.

+ or \pm Regency for Beatrix

Leonora Telles, consort of Ferdinand I, Regent

Considerable ability, at least in intrigue. Ambitious and energetic. Her character has been much censured, perhaps unjustly, as the chroniclers were under the patronage of the house of Aviz.

\section{Condition of Country}

1325-1357

In general peaceful and progressive. Agricultural, commercial, and legislative advance. Portugal assisted the Spaniards in defeating the Moors (Salado, 1340). Famines in 1333. Black Death, 1348. A 92-95; $B$ ii, $199 ; C$ iii, $205,206,208,213$; $G$ i, 248-50; $H$ ii, 172-174, 177, 194-197, 259.

\section{7-1367}

Stern enforcement of law and order. Commercial treaty and continuance of active trade with England. Agrieultural prosperity. Royal treasury enriched $a ; A$ 99-100; $B$ ii, $210 ; F$ i, $101-; G$ i, 264, 270; $I$ ii, 259.

General disruption. Lisbon
dis83
besieged, Portugal ravaged. De-
eadence in agriculture. Royal
reasure wasted. Some repairing
of castles and fortifications. Im-
povement in the marine. A
$99,100,103,104 ; B$ ii, $243 ; C$
ii, $219,221,222,224,227 ; F \mathrm{i}$
$28-146 ; H$ ii, $188-90,265$.
19,$287 ; N 82$.

1383-1385

Civil War. 
ROLER

+ John I, called "The Great,"

Brave and able, prudent, diplomatic, popular with the lower classes. $a$; $A$ 114-121; $B$ ii, $370 ; C$ iii, 245; $F$ i, 167-168; Q 133-135.

\section{\pm or $+\quad$ Edward 1}

of good natural ability but lacked energy and decision. Moderate and enlightened in his views, literature. $a$; A 127, 128; C 247, 256 ; EE 451-452; L 319; M 25, $26,32,209-211,217 ; Q 136$.

\section{- Minority of Alfonso V}

Regency divided.

$+\quad$ Minority of Alfonso V

Peter, uncle of the king, Regent

Brilliant qualities, excellent character, liberal and accomplislied. $a ; A 132 ; B$ ii, 381 ; $L 321$; $M$ i, 108 ; $Q 136$.

\section{- or $\pm \quad$ Alfonso V}

Weak and indecisive, with little practical wisdom, an instrument in the hands of his courtiers. Generous and impulsive, is acalso "The Father of his Country" truthful and affectionate, fond of

Condition of Country

1385-1433

Portugal greatly developed. Beginnings of expansion beyond the seas. Legislative improvement. Financial management not good at first. Taxes not burdensome. $A$ 110-127; $B$ ii, 365,371 ; $C$ iii, 234, 235, 244, 245, 246,$247 ; F$ i, $158-168$; L 300306,388 .

\section{3-1438}

Short reign. Disastrous expedition to Tangier. $A 127,128$; $B$ ii, 404; $C$ iii, 247, 256; $E E$ $451 ; \quad I I$ ii, $188-200,271 ; L$ 319 ; $M$ i, Chap. VIII.

\section{8-1439}

Brief period filled witl discord. $A$ 130,131; $H$ ii, 272, 273; $N$ ii, 39,71 .

\section{9-1449}

Progress, increased commercial relations with Africa, important first codification of the civil laws, minor pests (1439-1440). A 131, $132 ; B$ ii, 426, 433, 439; $C$ iii, $260 ; G$ iii, $397 ; H$ ii, $200 ; M$ ii, 71,89 .

\section{9-1481}

Country declined, finances wasted, exploration languished, minor pests $(1464,1466,1468)$. $A$ 133, 134, 144-154; $B$ ii, 500,

${ }_{1}^{1}$ Edward was intellectually active but not practical. As a ruler he cannot be ranked above mediocrity. 
RULER

counted very chaste. $a ; A 135$; $C$ iii, 275 ; $E E$ 569-571 ; $F$ i, 191$192 ; G$ iii, 395, 396, 414, 445, 447 ; $L 327,371$; $M$ i, 101 ; ii, 93.

$+$

John II

Called "the Perfect". - a great king. Resolute, keen, and subtle. Severe and of ten cruel. $a ; A$ 158,$159 ; B$ iii, $2 ; C$ iii, $35 ; F$ i, $189,195,196,200$.

\pm or $+\quad$ Emanuel

Called "the Fortunate." A difficult character to estimate. Mediocre or perhaps superior. His period has been too little studied. $a ; A 171,172 ; F$ ii, $5,13,19$.

\section{John III}

A narrow, unenlightened mind. "A weak and immoral bigot" (Jayne). $\quad A$ 178, 179; $B$ iii, 119 ; $F$ ii, 41-42; $K$ iii, 333; $P 120$.

Condition of Country $503,510,529 ; C$ ii, 262, 268, $269,275,276$; $E E$ Chap. IV; $F$ i, 189-94; $H$ ii, 191-194 200201, 274-277.

\section{1-1495}

Marked increase in trade and prestige. Further exploration, several minor pests during this reign. $A 156,158,163,165,169$; $B$ iii, 48,49 ; $C$ iii, $276,277,285$, $286,287,291,297,298$; $F$ i, 195209; $G$ iii, 101 ; $H$ ii, 201-205.

\section{5-1521}

Portugal's greatest days in outward splendour. Riches of the East poured into Lisbon. $A$ 170,$171 ; B$ iii, 53, 54, 58, 59, $96,109,110,111,116 ; G$ iii, $101,206,226-7$.

\section{1-1557}

$\pm$

Territorial increase and national supremacy maintained; but the germs of decay were beginning to show themselves. Inquisition definitely established. A 178,179 , $181,182,184$; $B$ iii, 120, 124, 153, 154; $C$ v, 192, 193; $F$ ii, 25-26, $41-42 ; K$ iii, $21,24,30,320$, et passim.

\section{\pm Catherine of Spain, Regent ${ }^{1}$}

Intellectual and energetic, but bigoted and unpopular. $a ; A$ 238,$240 ; B$ iii, 157, 160, $P 257$, 259. rulers.

${ }^{1}$ Above the average of princesses, but not above the average of actual 
RULER

\section{- Cardinal Henry, Regent}

$A$ vain, weak, and mean character. $a ; B$ iii, 157, 158, 159, $160 ; F$ ii, 57, 71 .

\section{Sebastian}

Ambitious, rash and adventurous. Tyramical, melancholic, an unbalanced and disordered mind. Killed in Afriea, aged 24. His ten-year roign necessarily merges in his minority. a; A 242-293; $F$ ii, $55-56$.

\section{- Cardinal Henry}

(Character above.) He was now, furthermore, old and dying.

\section{Condition of Country}

1562-1568

Decay made itself more evident. $A$ 241; $B$ iii, 161, 165-167, 170, $182 ; C \mathrm{v}, 194$.

\section{8-1578}

Disastrous war in Africa. Further deeline in national strength. Great pest (1568). A 241-245, 251-255; $B$ iii, 17s, 182, 216, 217 ; $C \mathrm{v}, 206 ; F \mathrm{ii}, 46-69$.

\section{$1578-1580$}

Country in turmoil and corruption. $A$ 2.57, 2.5; $B$ iii, 221, 222,$241 ; C$ v 211,$212 ; F$ ii, $70-75$.

"Sixty years captivity." Portugal under Spanish rule.

\pm or + Philip II of Spain

A difficult character to grade. Mentally he was ambitious, industrious in potty details, hut a procrastinator and cotirely lacking in judgment and brealth of view. He was gloomy, morose, suspicious, jealons, dissimulating, selfish, ungrateful, and by many considered ruel. His temperance is offset by his extravagant expenditures. His ehiof virtue appears to have bcen his patience. References under Spain.

\section{- $\quad$ Philip III of Spain}

Weak, indolent, with a tendeney to melancholia. Pious and wellmeaning, but pleasure-loving, extravagant and eareless. References under Spain.
1580-1598

Internal decay of Portugal eontinued, though its outward prestige remained ahout the same. $A 291,294 ; B$ iii, 111, 314, 316; C v, 219.

1598-1621

Financial exlraustion and mercantile decline in the East. $a$; A 294, 295, 299, 301 ; $B$ iii, 325327 ; $C$ v, 22s; $F$ ii, 109-112. 
RULER

Philip IV of Spain

Indolent and weak eharacter governed by Olivarez. Had a fair understanding and eultivated tastes. Luxurious and licentious. References under Spain.

\section{$\pm \quad$ John IV}

Indolent and pleasure-loving. A negative character, fond of music and hunting parties, devoted to religion. The queen, Louisa de Guzman, was the real head of the royal household. $a ; A 324$; $F$ ii, 138.

\section{+ or \pm Minority of Alfonso I}

Louisa de Guzman, Regent

Energetic, ambitious, and able. $a ; A 326 ; J$ ii, 78.

\section{- $\quad$ Alfonso VI}

Practically an imbecile, with uncontrollable vices and excesses. A 330 ; $F$ ii, 142.

\section{Condition of Cotntry}

\section{1-1640}

Disasters and discontent, further financial and commercial decline, increased poverty, increased taxes. $a ; A 299,301$, $303 ; \quad B$ iii, 336, 338, 356, 358, 363 ; $F$ ii, 115, 116.

$$
\text { 1640-1656 } \pm \text { or }+
$$

1640 Portugal proclaimed her independence. Wars against Spain charaeterized on both sides by weakness and indecision. Diplomatie position weak. Some revival of the nation's commercial aetivities. $a$; $A$ 324-325; $B$ iii, 379, 384, 389, 390, 399, 406 ; $F$ ii, $126-139$.

$$
\text { 1656-1662 } \pm \text { or }+
$$

Portugal's position somewhat strengthened, especially in the army. The tendency of the period secms questionable. Important vietory over the Spaniards (1659); but they were in possession of Southern Portugal (1662). Diplomacy rather suecessful. $a ; A$ 326-330; $B$ iii, 413,$427 ; C$ v, 245-246; $F$ ii, $127,130,131,139-141$.

\section{2-1668}

A period of wars with Spain, Portugal in the end suceessful. Internal affairs in a had condition. Methuen Treaty (1703) not generally considered advantageous to Portugal. $a ; \quad A$ 331-332; $B$ iii, 419, 422, 426, 427; $C$ v, 246, 247 ; $F$ ii, 131, 132. 
RULER

$\pm \quad$ Peter II, Regent and King

Ambitious, intriguing, and unprineipled. A rough, uncultured man with considerable shrewdness. His private life much condemned. $a ; B$ iii, 441, 468, 470 .

\section{$\pm \quad$ John V}

Superficial, luxurious, and extravagant. A notorious voluptuary. Had literary tastes and was not without a sense of justice. $a ; A 352-354 ; \quad B \quad 489$; $F$ ii, 150, 152, 163, 164.

$\pm \quad$ Joseph

A sensible, well-balanced character. (Supported the minister Pombal to whom the reforms are aceredited.) $a ; A 354 ; C \mathrm{v}$, $260 ; F$ ii, 181 .

\section{- Maria \\ Weak in intellect and finally beeame insane. Ruled jointly with Peter III her uncle and hus- band, who was also a mental weakling. $a ; A 370,373 ; F$ ii, 212,215 .}

\section{Condition of Codntry}

\section{8-1706}

Country remained unprosperous, in spite of the new influx of gold from Brazil. $a$; A 332$334 ; B$ iii, 442, 443, 470-471; $C$ v, $253 ; F$ ii, 143-145.

\section{6-1750}

Country eontinued to decline. Court and government espeeially corrupt. Wealth from Brazil did not suffice to mcet the waste and extravagance. Much building of churches, monasteries, and public buildings. $A$ 350-354; $B$ iii, $517-526 ; C$ v, $255-256 ; F$ ii, $150,151,164,172$.

\section{0-1777}

Reforms and internal improvements. Agriculture, finances, industry, and commerce advanced. Great earthquake. $a$; A 354$370 ; F$ ii, 206-209; 1215 .

\section{7-1788}

Deplorable state of affairs again. Fiscal decline. $a ; A$ $370-373 ; F$ ii, $212-217 ; N 215$.

\section{BIBLIOGRAPHY FOR THE NETHERLANDS}

a. Eneyclopedia Britanniea. 9th and 11 th editions.

b. La grande eneyclopédie. 31 vols. Paris, 1856-1902.

A. Blok, Petros Johanxes. History of the People of the Netherlands. Trans. by Osear A. Bierstadt and Ruth Putman. 5 parts. London and New York, 1898-.

[The best general history of the Netherlands.] 
B. Kampen, N. G. Geschichte der Niederlande. [In Geschichte der europäischen Staaten, Heeren und Ukert.] 2 vols. Hamburg, 1831-1833.

C. Motley, J. L. Rise of the Dutch Republic. 3 vols. New York, 1856. [Partisan in its spirit.]

D. Motley, J. L. History of the United Netherlands. 4 vols. New York, 1868.

E. Beer, A. Allegemeine Geschichte des Welthandels. 3 vols. Wien, 1860.

F. Davies, C. M. History of Holland and the Dutch. 3 vols. London, 1851.

[Although out of date, contains many useful facts.]

G. Wenzelburger, K. T. Geschichte der Niederlande. [In Geschichte der europäischen Staaten, Heeren and Ukert.] 2 vols. Gotha, 1879-1886.

H. Coxe, W. History of the llouse of Austria. 5 vols. London, 1820.

\section{RULER}

\section{$+\quad$ Philip I, the Good}

Enterprising, extremely ambitious. "A clever statesman," wrongly called "the Good." Was benevolent, affable, and just, but also ostentatious, immoral, and sometimes cruel. $a ; A$ ii, 123 ; $B$ i, 224; $F$ i, 252, 255; $G$ i, 359 .

\section{+ Charles I, the Rash, or the Bold}

An extremely able and ambitious warrior whose valour and zeal exceeded his judgment. Openhearted and free from deceit, but unscrupulous in his deeds. Rude and abstemious in his mode of life. Selfish and tyrannical, and notorious for his uncontrolled outbursts of passion. Cruel in revenge, but was a model of conjugal fidelity. $a$; $A$ ii, 144, 145; $B \mathrm{i}, 227,231 ; F \mathrm{i}, 260 ; G \mathrm{i}, 346$.

\section{Condition of Coentry}

1436-1467

Power of the country increased. Advantageous treaties led to growth of commeree and manufactures. Agriculture improved. Gain in public finance. Loss of personal liberty. $a ; A$ i, 329$338 ; \quad B$ i, 224; $E$ ii, 174-176; $F$ i, 252, 255, 256; $G$ i, 371, 396.

$$
\text { 1467-1477 } \pm \text { or }+
$$

Costly wars which brought the country no advantage. Taxation was excessive, but the fundamental conditions enabled it to be well met. Wealth of the burgher classes increased in spite of decline of political liberties. The wars were carried on chiefly beyond the border, so that comparative peace and order ruled in the Netherlands. $a$; $A$ ii, 134-145; $B$ i, $227,235,236,238-240 ; F$ i, $259-266,267,268,270 ; G$ i, $349,360,396-397$. 


\section{RULER}

Mary

Young and inexperienced. Twenty years old when she came to the throne. Twenty-five when she died. Intallert probably mediocre or inferior. Fond of outdoor sports. Popular with her subjects, partly on account of her heauty and graee, partly because of her lenieney or even slackness of governmeut. $a ; B$ i, $242 ; G$ i, 397 .

$+$

\section{Maximilian I}

\section{(Regent)}

Able, vigorous, eloquent, learned. Crafty and ambitious. Popular and magnanimous. Chaste and temperate in his habits. He is by some rharged with duplicity. (References under Austria.)

\section{- Philip, the Handsome}

Teak, insignificant, indolent. A profligate, deroted to pleasure. Gentle and pacific. References under Spain, also $B$ i, 270; $F$, 333.

\section{$+\quad$ Minority of Charles V (II)} Maximilian I, Regent

Able, vigorous, eloquent, learned. Crafty and ambitious.

\section{Condition of Country}

\section{7-1482}

Internal dissensions, which reduced the country to a state of desolation. The navy encountered a severe disaster. The "Great Privilege", was granted, which confirmed the people in their liberties. Bruges suffered, but Antwerp grew. $a ; A$ ii, $147 ; B$ i, 240-245; $E$ i, 176 ; $F$ i, 284, 291, 293, 294; $G$ i, $397-398$.

\section{2-1494}

A period of party struggles, revolts of the cities. "Bread and Cheese" war caused by famine in the northern provinees. Order established after ten years of disturbances and financial exhaustion. MI meh misery among the people. Heary taxes. Fisheries and cloth fabrication were injured. Measures taken for inreasing the naval power. $a$; $A$ ii, $150,151,154 ; B$ i, 246, 247, $249,250,251,252,255-256,257$, $259 ; \quad F$ i, 298-320; $G$ i, 378389, 398-401; $J$ i, 359-366.

\section{4-1506}

States lost thoir " Great Plivilege" hut enjoyed peace and sufficient liberty. Considerable commercial advance, especially with Spain and Portugal. $a ; A$ ii, $158 ; B$ i, 261, 262, 265, 270; $F$ i, 334; $G$ i, 389-394, 401-403.

\section{6-1507} $\pm$

Brief period without special significance. Maximilian accepted as Regent after some op- 
ROLER

Popular and magnanimous. Chaste and temperate in his habits. He is by some charged with duplicity. References under Austria.

\section{$+\quad$ Minority of Charles V (II)}

Margaret of Savoy, Regent, daughter of Maximilian I

Brave and vigorous. A wise and able administrator. Also the author of many works in prose and verse. Mild, affable, and condescending. $a ; A$ ii, 159 ; $B$ i, $271 ; F$ i, 384,$385 ; H$ ii, 12,86 .

\section{+ Charles V (II), the Emperor}

Sagacious, vigorous, accomplished, and tactful. Inordinately ambitious. Selfish and crafty. Gloomy and eccentric in his latter years. Much duplicity in lis character. References under Spain.

This period is a double rule, as Margaret was retained in the regency. Her influence must be added to that of Charles. $a$; $C$ i, $113 ; G$ i, 802, ii, 9.

\section{$+\quad$ Mary, Regent Sister of Charles V}

Strong, bold, masculine type. Had much ability. Cold, obstinate, and unpopular. To her influence must also be added that of Charles V. $B$ i, 330; $C$ i, $150 ; F \mathrm{i}, 297 ; G \mathrm{i}, 802$.

\section{Condition of Country}

position. Difficult to separate this period from the following. a; $A$ ii, 159; $G$ i, $359 ; H$ il, 12 .

\begin{abstract}
1507-1515
Administration of the government successful. Commerce and fisheries remained prosperous. Diplomatic position strengthened by alliance with England. A ii, 159,$247 ; F$ i, $336,337,360 ; G$ i, 395 .
\end{abstract}

\begin{abstract}
1515-1530
Agriculture, industry, and trade continued in a flourishing condition. Coinage reformed. Liberty alone suffered. Antwerp became the first commercial city in the world. $a ; B \mathrm{i}, 299$ $303,337-339 ; E$ ii, $176 ; G$ i, $792-815$.
\end{abstract}

\section{0-1555}

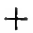

Conditions continued as above. $a ; A$ ii, $247 ; B$ i, $330 ; C$ i, 113 ; $G$ i, 792-815. 
Ruler

+ Emanuel Philibert of Savoy, Regent for Philip II of Spain

A brilliant soldier of fortune, but as far as his relations with the Netherlands are concerned his administration was brief and unimportant. He was better as a soldier than a governor. $a ; b$; $A$ ii, $247 ; D$ i, $150-152$.

\section{${ }^{1}$ Margaret of Parma, Regent Natural daughter of Charles V}

Proud, courageous, ambitious, and able. A masculine type of woman. Said to have been very deceitful. Was personally goodtempered and affable. The influence of Philip II and especially Cardinal Granvella is to be added. $a ; b ; A$ ii, 247; $C$ i, $227 ; F$ i, $505 ; G$ ii, 67-69.

\section{${ }^{1}$ Alva, Regent}

The influence of Philip II should be added.
Condition of Country

1555-1559

A period of discontent, not characterized by any important changes. Spain gained the important victory of St. Quentin over the French, in which the Dutch played an important part. Trade continued to increase (Kampen). $a ; A$ ii, 247; $B$ i, 336-351; F i, 491, 499.

\section{9-1567}

Conditions everywhere disturbed by the religious questions. Discontent, persecutions, uprisings. Great emigration of fugitives. Kampen has statistics to show the condition of trade between 1550 and 1566 . "In the summer of 1566 business had been practically at a standstill", (Blok). $a ; b ; A$ ii, 247, iii, 40; $B$ i, 336-351, 365; $C$ i, 293-4; $E$ ii, 178-9; $G$ ii, 67-69.

\section{7-1573}

Conditions similar to those above, though somewhat worse. $A$ iii, 43, 52, 56, 75; $B$ i, 367377,383 ; $C$ ii, 142-147, 279$290,403-411,412-457,500-505$, 517.

\section{3-cir, 1575}

This regency may be combined 1 Requesens, Regent

The influence of Philip II should be added.

with the preceding. $C$ ii, 511528. ruler.

${ }^{1}$ For these three periods it is not easy to say who should be considered the 
RULER

$+$ William, the Silent

One of the great men of all times. Able as a soldier, but was far more illustrious as a statesman. Was remarkably precocious. Possessed of indomitable encrgy and unbroken courage. Broad and patriotic in his views. Subtle and patient in his methods. Eloquent and accomplished, tolerant and humane. $a ; b ; A$ iii, passim; $C$ passim; G ii, 72-80.

\section{$+\quad$ Maurice of Nassau}

A military genius of the highest order. His political ability was less remarkable. Honest in the main, generous, and patriotic. Certainly devoted to whatever he considered to be his duty. Sometimes accused of arbitrary and personal motives. $a ; b ; A$ ii, passim; $C$ passim; $D$ passim; $F$ ii, 558, 559; $G$ ii, 884886.

\section{$+\quad$ Frederick Henry}

Though not equalling in genius William the Silent or Maurice, was a highly talented, prudent, and successful soldier and statesman. Sincere, generous, modest, and honorable. Showed remarkable constancy of character. $a$; $b ; A$ iv, 21 ; $F$ ii, 645 ; $G$ ii, 888 , 984-986.
Condition of Country cir. 1575-1584

Holland and Zealand gained their independence and liberty. United Provinces were established 1580. These remained comparatively tranquil and increased in prosperity, while the southern provinces (no longer included in this tabulation) declined. $a$; $b$; $A$ iii, 86, 88, 92, 105, 106, 128,$182 ; B$ i, 467-474; $C$ iii, passim.

\section{4-1625}

Dutch defeated the Spanish at most points. Virtual acknowledgment of the independence of the United Provinces. Increase in trade, manufactures, and general prosperity. East India Company founded (1602). Dutch become lords of the sea and chief traders of the world. $a ; b ; A$ iii, $272,289,291,323,324,336$; $E$ ii, $180 ; F$ ii, 198-199, 201; $G$ ii, $563-887$.

\section{5-1647}

A period of splendour. Increase in commerce and international prestige. Naval victories against the Spanish. $a$; $b ; A$ iv, 21-73; $B$ ii, 54-77, 99$106 ; E$ ii, $182-185 ; G$ ii, 889 , 987-990. 
RULER

$+$

William II

A youth of brilliant promise and precocious gifts. Brave, active, proud, and ambitious. Fiery and arrogant, though well-meaning and chivalrous. Died aged twenty-four. $a ; b ; B$ ii, 124 , $127,12 \mathrm{~S} ; F$ ii, 693.

The States

Governed, in theory at least, by the States-General and Council of State.

\section{Condition of Country}

1647-1650

The prestige of the country remained unimpaired. The United Provinces were recognized by Spain as free and independent. Popular liberty declined. Portuguese in South America injured the Duteh interests. $a ; b ; A$ iv, 151-75; $B$ ii, 99, 117-122, 124-125, 127 ; E 218 .

Como $\mathbf{1 6 7 2}$
Commercial prosperity re-
mained about the sime. Weak
diplomacy with decline in inter-
national prestige. Dutch colo-
nies in North America and Brazil
were lost, but colonial gains were
realized in the East. Internal
discord and discontent. Up-
risings in some districts. $a ; b$;
$A$ iv, 241-64; $B$ ii, $140,157-158$,
$177-181,18.5,187,185-189,227-$
$299 ; E$ ii, $182,184-185,218,220$.

1672-1702

The country was saved from the encroachments of France. Commerce shows a creditable record. Although the wars cost hearily, the country's credit was good at the close of the period. Nuch general increase of wealth. Revocation of the Edict of Nantes brought many desirable immigrants. $a ; A$ iv, $504-5 ; B$ ii, 271-272, 293, 319-320, 322-328, $374-376 ; \quad E$ 218-219; $F$ iii, 242243. $b$; Dictionary of National Biography ; $B$ ii, 2S2, 334; $F$ iii, 257, 259, 260-263. 
RULER

The States

\section{Condition of Country}

1702-1747

Decline in commerce and material prosperity. The political influence more distinctly declined. Army and navy deteriorated. Public corruption. Petty family interests placed over patriotic. Taxesincreased. $a ; b ; c$; $A$ v, 42-63; $B$ ii, 370-374, 384$385,391,393,409,420,435,437$, 441 ; $E$ ii, $219,222-223$; $H$ iv, 259.

\pm or - William IV

A cultivated though dull, quiet mind. Mediocre talents. Upright in character and zealous for the welfare of his country. $a$; $A \mathrm{v}, 125 ; B$ ii, $441 ; F$ iii, $420-$ 421.

\pm or - Minority of William V

Anne, daughter of George II of England, Regent

A woman of superior gifts and cultivation, but little good sense or judgment. Imperious, violent, headstrong. Selfish and ambitious. $a ; A \mathrm{v}, 127 ; B$ ii, 488; $F$ iii, $422,430$.

\section{Republic}

(The States exercised the power of Stadtholder.)
1747-1751 \pm or -

A period of internal commotion and some uprisings. Intended reforms were initiated, but the brevity of the period gives no opportunity to judge the outcome. $a ; A \mathrm{v}, 114-26 ; B$ ii, $437-441 ; \quad F$ iii, 404, 406, 407, 420.

\section{1-1759}

A fow years of comparative peace and well-being were broken at the advent of the Seven Years' War (1756). Dutch navy in a poor condition, commerce greatly injured. The diplomatic policy weak. $a ; A \mathrm{v}, 127-41 ; B$ ii, 442$444 ; F$ iii, 421-434.

\section{9-1766}

Conditions continued as before except that the navy became strengthened. In 1762 a serious business panic occurred. $A$ v, 142$50 ; B$ ii, 448-451; $F$ iii, 431-434. 


\section{RULER}

\section{William V}

Well-meaning, amiable, but weak and irresolute. Lazy and addicted to the pleasures of the table. $a ; A v, 151,169 ; B$ ii, $461 ; F$ iii, $433-441$.
Condition of Country

1766-1795

Trade injured by the English wars and American Revolution. Decay of commereial companies. Quarrels and disturbances. Diplomacy weak. The period ended in a revolution. Netherlands became virtually a province of France. $a ; b ; B$ ii, 456, 461, $465-477,456,500,532 ; F$ iii, $442-450,456,465-466,468-474$, $483,499,554-603$.

\section{BIBLIOGRAPHY FOR DENMARK}

a. Encyclopedia Britannica. 9th and 11th cditions.

A. Allen, C. F. Ilistoire de Danemark. 2 rols. Copenhague, $1 \times 78$.

B. Bars, R. N. Seandinavia. A llistory of Denmark, Norway, and Sweden. Cambridge, 190).

C. Devinu, S. A. llistory of Denmark, Sweden, and Norway. (Lardner's Cahinet Crelop). 3 vols. London, 1839.

fout of date. hut convenient for broad statements of sueh facts as go undoubted.]

D. Writueyer, H. (Editor). Denmark, Its Ilistory, ete. London, 1891.

E. Coxe, W. Travels into Poland, Russia, Sweden and Denmark. [Coxe has the reputation of heing very partial in his estimates of royalty.] 3 rols. 1784 .

F. Wrigur, J. H. (Felitor). A History of All Nations. 24 vols. Philadelphia, 1905.

G. Dahlmanis, F. C. Gesehichte ron Dännemark. [In Geschichte der europäischen Staaten, Ileeren und Ukert.] 5 vols. Hamburg, $1840-1902$.

\section{$+\quad$ Valdemar IV}

Considered to be a man of genius, great in war and stateeraft. Shrewd, energetic, indefatigable. Made everybody
1340-1375

Various regions were consolidated and reunited under a strong and orderly rule. Denmark became a powerful state. 


\section{ROLER}

work. Arbitrary and tyrannical in his nature. $a ; A \mathrm{i}, 200-201$; $B 6 ; C$ ii, 247 ; $D 10$.

$+$

Margaret Regent and Queen

Of remarkable ability. Prudent, vigorous, and despotie. Not much known of her private character. $a ; A$ i, 205, 219-220; $B$ 9; $C$ iii, 9 ; D 10-11.

\section{Eric}

Weak and incapahle, crucl, capricious, and violent. $A$ i, 220, 227-229; $B$ 9; $C$ iii, 10 .

\section{$\pm \quad$ Christopher III}

There is very little in history concerning his personal traits. Said to have had an "enlightened mind." $\quad C$ iii, 24, 26.

\section{$\pm \quad$ Christian I}

Active and brave, though of mediocre ability. Liberal, humane, amiable, and pious. $A \mathrm{i}$, 254 ; $E$ v, 272.
Condition of Country

Construction of many roads, canals, mills, castles, and fortresses. The wars were successful, except with the Hanseatic League. $A$ i, 192-201; $B$ 6; $C$ ii, 244-247, 249, 252; $D 10$.

\section{5-1412}

Sweden subjugated and consolidated with Denmark and Norway. Schleswig recovered. Peace and order were maintained. $A$ i, 205, 208; $B$ 8; $C$ ii, 256$259 ; D 10-11 ; E \mathrm{v}, 269$.

\section{2-1439}

Loss of territory. Disasters and defeats. Revolts of the people. Eric deposed. A i, 218$228 ; B 9 ; C$ iii, 11, 12, 14, 16; $D 11$.

\section{0-1448}

$\pm$

Brief and unimportant reign. Comparative peace and prosperity. Copenhagen grew in importance. Loss of influence over Sweden and Schleswig. Liberty of the peasantry declined. $A$ i, 230-235; $B 9 ; C$ iii, 23,24 , 25 .

\section{8-1481 \pm}

No marked advance or decline. Sweden subjugated, and then again lost. Finances in a bad condition. $A$ i, 248-254; $C$ iii, $35,36,37,42 ; F$ xi, 130 . 


\section{RULER \\ $\pm$ \\ John}

Mild, prudent, reasonable, popular. Subject at times to melancholia which bordered on insanity. $a ; C$ iii, 60; $E$ v, $2 S 3$.

\section{$+\quad$ Christian II}

Intelleetual, and extremely bold and enterprising. A friend of the lower alasses. Excessively crucl and obstinate. Mentally unbalaneed at timess $a ; A$, $26.7,267 ; B$ 12, 32; $C$ iii, 60; Ev, $283 ; F \times$ i. 130 .

\section{$\pm \quad$ Frederick I}

Of moderate ability, with good sense. 'Cautious, erafty, and peace-loving. No striking virtues or vices. $A \mathrm{i}, 30 \mathrm{~s} ; B 29$; $C$ iii, 104; $E$ v, 298 ; $F$ xi, 132.

Interregnum

Government divided.

\section{$+\quad$ Christian III}

A good ruler, patient, industrious, with strong common sense. $a ; A$ ii, $16 ; B 67$.
Condition of Country

$$
\text { 1481-1513 } \pm \text { or }+
$$

Wars with Sweden which came to no profit. Disastrous invasion of Ditmarsh. Nary enlarged. Finances improved. Advantageous treaty with the Hanseatic towns. $A$ i, 243, 259-265; $B$ 11 ; $C$ iii, 5s-59.

\section{$1513-1523$}

Improved jurisprudence and increase in commere. Better condition of the peasintry. Oppression of the nobles led to revolts and flight of the ling. Sweden subdued, and then (1520152:3) gradually under the leadership of (iustarus lasa threw off the Danish yoke. 4 i, 271, $275,276,277,255 ; \quad I 326,27$; $C$ iii, 62, 64, s4, 85,$86 ; D 13,14$.

\section{$1523-1533$}

Events of the Reformation. No marked prouress or deeline in material conditions. Diseontent among the peasantry. $B$ 30 ; $C$ iii, $89,90,93,104$.

\section{$1533-1534$}

Civil wars. Violences and eruelties. $A$ i, 311-314.

1534-1559

Comparative peace and prosperity. Commerce inereased. Several wise laws enacted. $a$; $A$ ii, 15,$16 ; B$ 66-75; $C$ iii, 113. 
RULer

\section{$\pm \quad$ Frederick II}

Of mediocre ability. Tactful and popular.

Frederick II was assisted by many able ministers. $a ; A$ ii, $29 ; B 84,85 ; C$ iii, $138 ; F$ xii, 105.

\section{- Minority of Christian IV (Regency divided.)}

\section{$+\quad$ Christian IV}

Brave, active, vigorous, able. Magnanimous, with a high sense of duty, he is the best-known king of Danish history. His nature, however, was overambitious, selfish, and sensuous. $a ; A$ ii, 47, $50,56,64,68$.

\section{$\pm \quad$ Frederick III}

An enigmatical character. Shrewd and calculating. Brave on occasion. Mild, prudent, and amiable. Charged with selfishness and duplicity. $a$; A ii, 110 ; $B 238$; $C$ iii, 163, 1S3; D 16.
Condition of Country

1559-1588

Increased international prestige. Better financial condition. More commerce and industry. Many public buildings erected. Subjection of Ditmarsh. $a ; A$ ii, 17,$21 ; B$ 84-S5; $C$ iii, 138 ; F xii, 105 .

\section{8-1596} $+$

Order and prosperity maintained. $a ; A$ ii, 30; $C$ iii, 139.

\section{6-1648}

In the first part of this reign Denmark enjoyed much commercial and industrial advauce, and many internal improvements. In the last part she suffered severely from foreign wars, especially in her conflicts with Gustavus Adolphus of Sweden. $a ; A$ ii, 49, $50,52-68 ; B$ 151-155, 158, 162; $C$ iii, 143, 144, 150, 151, 152; D 15-16. 


\section{RULer}

\section{Christian V}

Brave, but weak and incapable. Good-natured and popular, but extravagant and devoted to ase and pleasure. $a ; A$ ii, 131 .

$+$

Frederick IV

Vigilant, able, and sucressful. Amiahle, popular, and well-meaning. Immoral in his private life.

Accused of "unprincipled amhition." $A$ ii, 14s, 149; $B$ 298; C iii, $283 ; F$ xiv, 95 .

$\pm$

\section{Christian VI}

Mediocre ability. Diligent and sineere. Ruled by others. Shy, sickly, and mildly melaneholy. Benevolent and pious. $A$ ii, 169 ; $B$ 399, 401; C iii, 2\$2-283.

$\pm \quad$ Frederick V

Intelligent but not brilliant. Moderate, well-meaning, and conscientions. $A$ ii, 170,$187 ; B$ $401 ; F$ xiv, 316.
Condition of Country

1670-1699

$\pm$

Wars with Sweden, barren of results. Commercial advance and better navy. Decline in agriculture, finances, and eondition of the peasantry. Weak diplomatic position. $a ; A$ ii, $112,114,126,127,128 ; B 276$, 299 ; $C$ iii, 185,$158 ; D 20$.

\section{$1699-1730$}

General prosperity. Schleswig arquired and annexed to Denmark. Fiseal condition much improved. Many sehools built. Condition of peasantry ameliorated. Serflom abolished. $a ; A$ ii, 138, 142, 147; $D 21 ; F$ xiv, 95 .

$1730-1746$

$\pm$

A period of peace. Growth of industries. A better navy. Decline in finances, agriculture, and liberty of the peasantry. $A$ ii, $151,152,153,157,166,167$; B 398, 399; $C$ iii, 282-2s3; D 23.

\section{6-1766}

Condition of peace continued. Commerce and industry advanced. Agrienlture and the peasantry in a bad way, but improvement was shown during the last part of the reign. $A$ ii, $174,175,176,180-185,187-189$; B 399,400 . 
RULER

Christian VIII

Weak and ignorant. A dissipated degenerate. Practically insane. $C$ iii, $299 ; B 401 ; F \mathrm{xv}$, 242.
Condition of Country

1766-1808+or \pm

The sweeping reforms of Struensee occupied the first part of this reign. They were of questionable value. Last part of the reign was progressive. $C$ iii, 299-302; $B$ 403, 405, 406, 410 .

\section{BIBLIOGRAPHY FOR SWEDEN}

a. Encyclopedia Britannica. 9th and 11 th editions.

b. Biographie Universelle. 85 vols.

c. La grande encyclopédie. 31 vols. 1S\$6-1902.

d. Brocknaus. Konversations Lexikon.

A. GeiJer, E. G. The Ifistory of the Swedes, translated by J. A. Turner, London. First portion, eomprising first three vols, of the original from the earliest period to the accession of Charles $\mathrm{X}$. (Continuation, see French or German editions.) IS45.

AA. Geijer, E. G. Gesehichte Schwedens. (In Heeren und Ukert Geschichte der europäischen Staaten. 4 vols. Hamburg, 1832 - Gotha, 1855.

B. Dunhau, S. A. History of Denmark, Sweden, and Norway. (Lardner's Cabinet Cyclop.) 3 vols. London, 1839.

[Out of date, hut useful to compare with modern opinions.]

C. BeEr, Adolf. Allgemeine Geschiclite des Welthandels. 3 vols. Wien, 1860-84.

D. Writit, J. H. (Ełlitor). Ilistory of All Nations. 24 vols. Philadelphia, 1905.

E. Coxe, W. Travels in Poland, Russia, Sweden, and Denmark. 3 vols. 1784.

F. Barn, R. Nisbet. Seandinavia. A Political History of Denmark, Norway, and Sweden from 1513 to 1900. Cambridge, 1905.

G. Bain, R. Nisbet. History of Charles XII. New York, 189;.

H. Sundarkg, Gustay (Editor). Sweden, Its People and Its Industry. Historical and statistical Handbook, published by order of the government. Storkholm, 1904.

J. Carlson, F. F. Geschichte Schwedens, continuation of Geijer. 3 vols. Gotha, $1875,1887$.

K. Stavenow, Ludvig. Geschichte Sehwedens, 171S-1772.

[The seventh volume and continuation of the work of Geijer and Carlson in Heeren und Ukert, ete., series.] Gotha, 1908. $2 \mathrm{~A}$ 


\section{RULER}

\section{$+\quad$ Gustavus Vasa}

A man of very high ability. Brave, cautious, eronomical, and extremely industrious. Stern, just, and even tyrannival, but virtuous and popular. $a ; b$; $A$ i, 14t; $B$ iii, $205 ; D$ xi, 140 ; $F: 33,59$.

\section{$\pm \quad$ Eric XIV \\ of brilliant mental endow-} monts. "A good orator, poet, musician, and painter." Deroid of practical wisdom, "an incompetent ruler." Suspicious, violent, cruel, and headstrong. Became at times mentally doranged. $a$; $b ; A$ i, $145 ; D$ xii, 104 ; $F 116$, 124 .

\section{$\pm \quad$ John III}

Laarned, and gifted as a student. As a ruler his position is doubtful. An unbalanced mind. Violont, selfish, dishonourable, extravagant. $A$ i, $146 ; B$ iii, 214; $E$ iv, $187 ; F$ 129, 132 .

\section{Sigismund}

Weak and higoted, though cultivated in literature and the arts. Unreliable, wilful, and obstinate. Devoid of exceutive force. $a$; E v, 174; F 13s.

\section{- Sigismund and \\ $+\quad$ Duke Charles (afterwards Charles IX)}

Charles acted as regent for Sweden. Sigismund was King of Poland.

\section{Condition of Country}

1525-1560

Sweden won her independenco from Demmark. Law and order maintained. Increase in commerce. Considerable progress in agriculture and mining. Taxes alleviated. $a ; A \mathrm{i}, 134,145 ; B$ iii, 205; C ii, 422; $D$ xi, 140, 141.

\section{$1560-1568$}

Public treasure wasted. Much general discontent and suffering. Reign ended in a robellion in which Eric was deposed. $a$ : A i, 147, 149; $D$ xii, 105,$106 ; F 115-125$.

\section{$1568-1592$}

Much disorder and want of economy. Industry made little progress. Events of the Catholic reaction. Wars with Russia, which lad to some conquests along the Baltic. $A$ i, 177, 178; D) xii, 106, 109; F 126, 127, 133.

\section{$1592 \quad 1595$}

Religious disturbances continued. F 134-135.

\section{5-1600}

Religious and personal warfare between Charles and Sigismund. The latter deposed. $F$ 135-139. 


\section{Ruler}

$+$

Charles IX

Strong, decisive, and sagacious. Zealous to promote the interests of his people, yet severe in the exercise of his power, and subject to violent fits of passion. Unscrupulous in his methods. $a ; A$ i, 209; $B$ iii, 221; $D$ xii, 146; $E$ v, $175 ; F 143$.

\section{$+\quad$ Gustavus Adolphus}

Of exeeptional genius. A great warrior and statesman. Alored by his subjeets for his many noble virtues. $a ; b ; B$ iii, 232; $D$ xii, 229 .

\section{Minority of Christina \\ Regency divided}

(Oxenstierna, a non-royil statesman, at the head of affairs.)

$+$

Christina

Superior intellect and many learned aceomplishments. Her character was extremoly erratic. Mistrustful, haughty, satirical, passionate, and licentious. $a ; b$; $A$ i, 148,324 ; $B$ iii, 236 ; $D$ xiii, 129 .

\section{Condition of Country}

\section{0-1611}

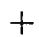

Successful diplomacy. Commeree, manufaetures, and mining flourished. Improved judiciary. Unsueeessful war with the Danes in the last years of his reign. $a ; A$ i, 207; $C$ ii, 483$4 S 4$; $D$ xii, 137 ; F 142-143.

\section{1-1632}

Marked growth of Sweden's international prestige. Great improvement in the army, whieh gained many brilliant vietories. Aequisition of Ingria, Riga, and a part of Karelia. Prosperity in all economie conditions. $a ; d$; $A$ i, 222, 228, 230; $C$ ii, 484; $D$ xii, 229 .

\section{2-1644}

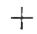

Sweden eontinued to play a successful part in the Thirty Years' War. Reforms in the internal administration. Manufactures, especially of arms and ammunition, were in a flourishing condition. $a ; A$ i, 294-296, 310 .

$$
\text { 1644-1654 }+ \text { or } \pm
$$

Suceessful termination of the wars with Denmark (1645) and also of the Thirty Yoars' War (1648) in which Sweden obtained the duehies of Bremen, Verden, most of Pomerania, and Wismar. Sweden very high among the nations. In the last years came a general discontent and peasant uprising. $a ; A$ i, $343 ; B$ ii, 234 ; $C$ ii, 455 ; $F$ 221-227. 
RUler

\section{$+\quad$ Charles X}

Extremely brave and enterprising. An able general. In the main just, though prone to fits of anger. $a ; A A \mathrm{iv}, 351-357 ; B$ iii, $239 ; E$ iv, 39, 44; $F 229$, 250, 256.

- Minority of Charles XI Regency divided.

\section{$+\quad$ Charles XI}

Ambitious and energetic, with high political ability. (haste, temperate, economiral. Anxious for the welfare of his country. He was, however, stubborn and severe, and considered by many an unprincipled tyrant. $a: B$ iii, 247; $D$ iii, 274; $E$ iv, 47-49.
Condition of Cocntry

1654-1660

Denmark foreed to give up Scania, Halland, Blokinge, and other territorios. Sweden maintained her international prestige. The wars were, however, burdensome. $a ; c$ : AA iv, 206, 219, $351-357 ; \quad B$ iii, 240; $C$ ii, 485; $E$ iv, $35 ; F 229-257$.

\section{$1660-1672$}

Increased trate and industry, especially irom and silver. Improved jurisprudence. Livonia arquired by swertell. On the other hand there was much fermenting discontent among the lower rlasses. The finanees wore very badly managed. The foreign policy was wak, Sweden playing into the hands of France. $a ; d ; A A$ iv, 425, 431, 432-436, $435,440,532-547 ; C$ ii, 485 ; Fv, 292-94; (i 10-12.

\section{$1672 \quad 1697$}

From 1672 t1 1679 a period of wars in which Sweden was at first humiliaterl but finally victorious. Latter part of the reign, peace and prosperity with marked progress in commerce and industry. Improved financial condition, attained, however, by measures injurious to a certain minority of the subjects. $a ; c$; $A A$ iv, 577, v, 1-56, 450-475; $B$ iii, 245; $C$ i, 485; $D$ xiii, $274 ; E$ iv, 47 . 


\section{RULER}

\section{- Minority of Charles XII}

Regency divided. (Count Piper, Prime Minister in fact though not in name.)

\section{$+\quad$ Charles XII}

An extraordinary martial genius. "His ambition was madness and his valour was ferocity." Rude but chaste, simple in his mode of living. "Indifferent monarch, but a great soldier.", $a ; b ; B$ iii, $277 ; E$ iv, 50 .

\section{Olrica Eleanor}

Deficient in courage and talent. Considered to have a penchant for intrigue and a vindietive nature. She is credited with domestic virtues. $G 21,259,260$; K 30 .

\section{Frederick I}

Well-meaning but weak and lazy. Politically, a nonentity. $a$; K 32-33.
Condition of Codntry

April 5-Nov. 6, $1697 \quad \pm$ or +

Dissensions and disturbances. Diplomatic strength fairly well maintained. Good financial management continued. $a ; A A$ vi, 4-6; $G$ 36-37.

\section{7-1718}

Foreign wars which brought misfortune and poverty upon the country. Decline in trade, industry, and agriculture. Some excellent civil and criminal laws were enacted. Loss of the Baltic provinces to Russia. $a$; A vi, 41, 103, 176-179, 310-315, 320, $351-353 ; \quad B$ iii, 278; $C$ ii, 485486 ; $D$ xiii, 340.

\section{March, 1719-April, 1720}

Loss of Bromen and Verdeen to Hanover, but these and other events belong to the treaties which closed the wars of Charles XII. $a ; B$ iii, 278.

$$
\text { 1720-1751 + then - }
$$

First twenty years were peaceful and progressive under direction of Horn. Increase in commerce, trade, mining, and general exports. Kingdom placed in a better state of defence. In 1741 Sweden fought a ridiculous and unsuccessful war with Russia. In 1743, humiliating Peace of Abo, by which Sweden lost Eastern Finland. $a$; $B$ iii, 280 ; $C$ ii, 488-489; $D$ xiv, $110 ; F$ $350-353 ; \quad H 87$; $K$ 89-122, 189205. 
RULER

- or \pm Adolphus Frederick

Mentally inferior. Weak and indeeisive. Mild, temperate, and peace-loving. $B$ iji, 246,$249 ; D$ xiv, 317; $E$ ir, 52: $F 353-1$.
Condition of Coentry

1751- 1771

Country in a state of lethargy. Its international influence had hecome insignificant. Internal commotions. Decline in manufactures. Peasantry oppressed. Government herame notoriously corrupt. $a$; $B$ iii, 2\$6, 287; $C$ ii, $487 ; D$ xiv, 317; $F 351-359 ; H$ 87.

\section{1-1792}

Revival of agriculture, industry. and eommeree. Beneficial reforms in the administration of justice. $a$; ( $\mathrm{ii}, 4 \mathrm{4}) ; 1) \mathrm{xv}, 239$.

\section{BIBLIOGRAPII FOR RUSSIA}

a. La Grande Encyolopédie.

b. Enerroperlia Britannida. 9th and 1 th editions.

c. Brocknats Komversations Lexikon.

A. RAmBotD, AlfiEd. The History of Russia from the Earliest Times to 1si. Translited by L. B. Lang. 2 vols. London.

B. Strahl EXd IIErruax. Geschichte des russisehen Staates (in Heeren und I'kert series). 7 vols. Hamburg and Gotha, $1839-66$.

C. Kelly, Walter K. The History of Russia, eompiled from the works of Karamsin, Tooke, and Segur. 2 rols. London, 1854.

[Out of date.]

D. Beer, Adolf. Allgemeine Geschichte dos Welthandels. 3 vols. Wien, $1860-84$.

E. Solover, S. M. llistoire de Russie. Translated from the Russian by the Princess Souvoroff. Paris, 1 \$ 79.

F. Bars, R. Nisbet. Slavonic Europe, a Political Ilistory of Poland and Russia from 1147 to 1796. Cambrigere, 1905. 
G. Morfill, W. R. Russia (in the Story of the Nations Series). London, 1904.

$H$. Waliszewski, K. Le berceau d'une dynastie, les premiers Romanov, 1613-1682. Paris, 1909.

J. Ralstox, IV. R. S. Early Russian History. London, 1874.

K. BaIs, R. N. The First Romanovs. London, 1905.

$L$. Waliszewsin, $\mathbf{K}$. The Romance of an Empress, Catherine II of Russia, translated from the French. 2 vols. London, 1894.

M. Waliszewski, K. L'héritage de Pierre le Grand, règne des femmes, gouvernement des favoris, 1725-1741. Paris, 1900.

N. Waliszewski, K. La crise revolutionnaire, 1584-1614. Paris, 1906.

O. Morfill, W. R. A History of Russia from the birth of Peter the Great to Nicholas II. London, 1902.

P. Bars, J. N. The Pupils of Poter the Great. Westminister, 1897.

Q. Bar, J. N. The Daughter of Peter the Great. Westminister, 1599.

R. Waliszewski, K. La dernière des Romanov. Paris, 1902.

RULER

$+\quad$ Ivan III, the Great

Cool, resolute, delibcrate, and economical. A shilful diplomatist, stealthy and comning in his methods. Tyrannical and passionate. $a ; A \mathrm{i}, 217 ; B$ ii, $314,431-435 ; F 35 ; J 206,207$.

\section{$\pm \quad$ Vassili V}

Not brilliant, but possessed industry, prudence, tenacity, and diplomatic cumning. Very autocratie in his rule. $c ; A \mathrm{i}, 242$; $B$ iii, 1 ; $C$ i, 132; $F 105$; $J 137$.

\section{Condition of Country}

\section{2-1505}

Russia founded as an empire and consolidated. Conquest of Norgorod, Bulgaria, and a part of Lithuania. Accpuisition of Trer, Rostoff, Yaroslav, and Kazam. Army and finanees strengthened. Considerable building activity. b: $A \mathrm{i}, 226,2333$; $B$ ii, $432-435$; $F^{\prime} 3 ;-10 ; J 108,110,122,129$; G 59-60.

$$
\text { 1505-1533 tor } \pm
$$

Strength of the empire maintained. Some reverses at the hands of the Tartars, but in the end the country was enlarged and strengthened. Many hardships endured by the people, such as famines, fires, and pestilences. Suecessful foreign diplomacy. $b$; $A$ i, 233; $B$ iii, 49-52; $C$ i, 132$133 ; F 104 ; J 137,135,140$. 
RULER

$t$ or + Minority of Ivan IV

Helen Glinska, stepmother of Ivan IV, Regent

Able and resolute, hut unpopular and immoral. $b ; B$ iii, 57, $60 ; C \mathrm{i}, 133-134$.

\section{- $\quad$ Minority of Ivan IV Regency divided}

\section{Condition of Country}

1533-1538

Not an important period. Despotic authority and order maintained in spite of court intrigues. Ninor wars in Lithuania and Crimea. $B$ iii, 73-76; $C \mathrm{i}, 133-134 ; F 106$.

\section{$1538-1547$}

Intrigues, uprisings, and disorders. Tartars harried the empire. State treasury plundered. $B$ iii, 57, 60-73, $78-86$; F 106107.

\section{$+\quad$ Ivan IV, the Terrible}

Energetic and very able, especially in statecraft. Was merciless and dissolute. Notoriomsly crucl and superstitious, especially the last part of his life, when he became virtually a madman. $a ; b ; A$ i, 279; $B$ iii, 167-21s, 283-28s; C 13s; $F$ $109-112 ; G 65,70,71,79,132-$ $133 ; J 142-143$.

- Feodor I

Extremely weak-minded. Had a good character, pious and philanthropie. (Boris Ciolunov the real ruler. See below.) $b ; A \mathrm{i}$, $311 ; B$ iii, 376, 377; F 163; J 149, 212; $G 89,90$.

\section{7-1584} quered and annexed. Siberia invaded and partly sublued. Many ehurches built. Some increase in foreign trarle. Famino and pestilence in 1570. Not all the wars were suceessful. Moscow was burned hy the Tartars in $1574 . b ; A \mathrm{i}, 252,302 ; B$ iii, 96-102, 11s-123, 218-219; C i, 136-146; I) 502; F 112-130. $G 67,70,72,76-79,82-85$.

\section{$1584-1598$}

Empire strengthened. Tartars repulsed. Smolensk fortified. Arehangel built. Swedes driven into Narva. Further subjugation of Siberia. Commercial relations broadened, peasantry bound to the soil and consequent depopulation. $b ; A \mathrm{i}, 316 ; B$ iii, 381, 382-384, 386-397; $C$ i, $162,163,165$; $F 158,161-162$; $G 93$.
Kazan and Astrakhan con- 
RUler

\section{Boris Godunov \\ Brother-in-Law of Feodor I}

Great capacity and unbounded ambition. A tyrant. Cunning, unscrupulous, and suspicious, but not wantonly eruel. Patronized literature. $a ; b ; A \mathrm{i}, 321 ; B$ iii, 377, 438; $F$ 160-161, 165$166 ; G 98 ; J 150$.
Condition of Cocntry

1598-1605 \pm or +

Externally Russia's diplomatie position strengthened. Internally great eommotion during the last six months attending the false Demetrius. Great famine (1601 1603). Depopulation among the peasantry, but there was an influx of desirable foreigners. $b$; $A$ i, 320; $B$ iii, 439, 450-451, 456-458, 459-461; C 166-178; F $166-172 ; G 98 ; J 156$.

\section{April 13, 1605-June 1, 1605 -}

Treasons and conspiraeies. $b$; $B$ iii, 469-470; $C$ i, 180. in less than two months. Reign may be considered a minority with the power divided.

\section{$\pm \quad$ Demetrius}

Ambitious, eourageous, aceomplished, versatile, but imprudent. Good-natured, affable, and wellmeaning. Magnificent and $\mathrm{ex}-$ travagant. $B$ iii, 474, 475; $C$ i, $169,172,182,186,187,201 ; F$ $173-174 ; J 162$.

\section{\pm or - Vassili (Basil) Shuiski}

A crafty and unserupulous intriguer. Timid in action, faithless, and unpopular. "A nervous little old man, very shrewd and very stingy." $B$ iii, $4 \$ 3$; $C \mathrm{i}$, $189,190,201 ; F 176 ; J 220,221$.
1605-May 18, 1606

Establishment of a more peaceful condition of affairs, and many beneficial laws, soon followed by a couspiracy in whieh Demetrius was murdered. Treasury depleted. $B$ iii, 474, 477-481; $C$ i, 184, 1s9-200, 201; G 104 .

\section{6-1610}

Russia invaded by the Poles. General confusion. Tartars plundered the border. $b ; B$ iii, 485-502; $C$ i, 202, 208, 209; $F$ 176-180; J 167-168; G 104, 105 . 
Ruler

- Interregnum

\section{Condition of Codntry}

\section{0-1613}

Anarchy for two years followed by the expulsion of the Poles. Civil disorder, however, continued until 1613. Treasury plundered. $b ; A$ i, 346; $B$ iii, 502512 ; C i, 210-215; F 181-186; J 169-171; G 105-107; K 30, 40.

\section{$\pm \quad$ Michael Romanov Ruled jointly with his father \\ + Feodor (Philarete) from 1617 to 1633}

Michael was an amiahle, honorable, conscientions prince of mediocre or perbaps superior caparity.

Feodor (Plilarete), of similar temperament, and equally virtuons, was highly enclowerl with wisdom and ahility. $F$ 191; $G$ $106 ; H 52 ; K 47,61,67$.

\section{- Minority of Alexis Botis Morosoff in control}

\section{\pm or $+\quad$ Alexis}

About the average in mental capacity. A well-balanced mind. Very industrious and conscientious. He is especially noted for his good nature, humanity, and

\section{3-1645} try somewhat improved, especially in the condition of the people, in rommerce, manufactures, amd the army. Population increased through tho introduction of many desirable foreimners. $b ; d ; A$ i, $356 ; B$ iii, 539-54s; $C$ i, 215, 217; $F$ 1SS, 189-191, 193-194: $G$ 107, $108 ; K 41,50,55,60,67,121$.

1645-1650 \pm or $t$

Much oppression, injustice and discontent. Several insurrections and riots. On the other hand the army was improved and the frontiers strengthened. $b ; B$ iii, 589-598; $C$ i, 218, 219; $H$ 58-59, $60,61,65-74,80 ; K 96-98,100$, 102 .

\section{0-1676}

In spite of troubles the reign was undoubtedly a period of progress. Codification of the laws. Incorporation of the country of the Cossacks, and territory gained
Internal condition of the coun- 
RULER

gentle, courteous behaviour. Good husband and father. $a ; b ; G$ $130 ; \quad$ 5 510-522; K 189.

\section{Feodor III}

Reigned from the age of fourteen to twenty years. (Nay be considered as a minority or divided regency.)

\section{\pm or + Minority of Ivan and Peter the Great \\ Sophia, Regent}

A remarkable person of exceptional courage, force, and much ability. Historians differ in their estimate of her moral character, some picturing her as unscrupulous, cruel, and licentious, others as comparatively blameless. $F$ 281-284; $G$ 133-134; K 195-196.

$+$

Peter the Great

Extraordinary ability, willpower, and energy. Impulsive, passionate, tyrannical, but often clement. Coarse, brutal, lieentious, epileptic. $a ; b ; c ; B$ iv, $309-313 ; \quad F \quad 285-287 ; \quad G$ 162173.
Condition of Country

from Poland. Minor rebellions put down. Trade and foreign relations broadened. Finance, however, remained in a bad condition. $b ; d ; B$ iii, 626 , $627,648-651,660-666 ; C$ i, $221-223 ; G 117$; H 56.

1676-1682

Successful wars with the Tartars. Several reforms, one of which, the abolition of the Myestnichestvo, was important. $c ; A$ i, $400 ; \quad H$ 536-544; K 192-194.

\section{2-1689}

A period of confusion and massacres. Insurrection of the Stclitz. Unsuccessful expedition against the Tartars. $b ; B$ iv, 1-29; C i, 227-234.

1689-1725

Order established with a firm hand. Addition of the territories of Little Russia, Livonia, Ethonia, Ingria, and a part of Finland. Seaports obtained. St. Petersburg founded. Foundation of a navy. Improvement of the army. Increase in manufactures, commerce, and the liberal arts. $b ; c ; A$ ii, chaps. I-III ; $B$ iv, 333-347, 364-365, 367, 393-402, 406-411; $C$ i, 272-278, 289-291, $293,298-299,310,339,345,347$, 349 , 353 ; $D$ ii, 504-507 ; $E$ 473488 ; $F$ 298, 309, 326-327. 


\section{RULER \\ - or $\pm \quad$ Catharine I}

Ignorant, unambitious, though shrewd and sensible. Not much political ability or inclination to direct the helm of state. Life indolent and intemperate. Gentle in disposition and very humane. $b ; A$ ii, $123 ; B$ ir, 482 ; $C$ i, 36.5, 397, 398, 399-400, 401. F 329-330; MI 13; O 110-111, 114; P 111-113.

\section{- Minority of Peter II \\ Regeney in the hands of a coun- cil.}

\section{- Anne Ivanovna}

Had a fair natural intelligence, but her mind was narrow and uneducated. Many had traits of rharacter. Sullen, vindictive, selfish and sensuous. Laziness alternated with bursts of energy. $F 340,341$; $G 191$; $M$ 163-173; O 142-144; $P 176,182,195,199$, $2 \$ 0,284-285$.

Minority of Ivan VI Regency of Biren
Condition of Coontry

1725-1727

A peaceful reign without marked internal change. Diplomatic relations strengthened with Austria and Germany. Taxes reduced. $A$ ii, $132 ; B$ iv, $472,475,478-480 ; C$ i, 397; F 330-332; G 176-177; O 113.

\section{7-1730}

Intrigues in the court. No marked advance or decline. Maurice of Saxony prevented from getting possession of Courland. Diplomatic apathy. $b ; B$ 507$530 ; C$ i, 402-403; $F$ 335-338; $O 119$; P 124-127, 146-14S; Q 9.

$$
\text { 1730-1740 } \pm \text { or }+
$$

Reforms in the army. Poor condition of the nary. Canals and public roads built. Successful intervention in the affairs of Poland. War with the Turks not especially successful, but Russia gained a few towns, though at much expense. 20,000 persons said to have been banished to Siberia. Inereased taxation and oppression. $b ; c ; A$ ii, $144 ; B$ iv, 557-594, 626-628; $C$ i $407,410,412-415,418,421$; $E$ 516-526; $F$ 350; $O$ 125, 131, $132 ; P 177,199,318 ; Q 20$.

\section{Oct. 28, 1740-Nov. 20, 1740}

A short period without any special significanee. Overthrow of Biren's regency. $\quad b ; A$ ii, 132 ; $B$ iv, 507-530; $C$ i, 402, 403 . 
RULeR

Minority of Ivan VI

Anne Leopoldovna, Regent

Indolent, timid, and very ineapable. Lacking in ambition. Lived in seclusion. Dissolute and slothful. Except her natural mildness, had not a single quality which could by any possibility command respeet or admiration. $A$ ii, $154 ; E$ 528; $F 530 ; M$ $288, \quad 307,312-318 ; \quad Q \quad 30-31$; $40-42$.

\pm or +

Elizabeth

Uneducated, but possessed a very keen mind. Indolent and selfish, eaprieious, and indulgent. Good-natured, but subjeet to outbursts of passionate anger. Extravagant and extremely licentious. $a ; A$ ii, $173 ; B$ v, $176-177 ; G 202 ; O 202 ; P 150$; $Q 71,131-142 ; R$ 36-98, 534.

\section{Peter III}

Half imbeeile. Weak, dissolute, violent. Was, however, called "good-hearted." Indolent. $b ; B \mathrm{v}, 242,243 ; L$ 87,$100 ; O 192,193,195,196 ; Q$ 98, 193.
Condition of Codntry

Nov. 20, 1740-Dec. 6, $1741 \pm$

A short period. Intrigues and violence soon led to the overthrow of Anne, Ivan VI, and their party. Swedes defeated (Sept. 3,1741 ), but the Russians did not follow up their vietory. $b ; B$ iv, $660-675 ; C$ i, 423-424; $E$ 528-531.

Pomerania and the southern part of Finland acquired. Increase in eommerce and manufactures. Improvements in banking. Siberia began to be peopled. Mueh tyranny. A large number of persons banished to siberia. Treasury exhausted through extravaganeies. Many public buildings erceted. $b ; c ; A$ ii, 167,171 ; $B \mathrm{v}, 170,171,176 ; C \mathrm{i}, 429,440$, $443,445,446,450 ; E$ 541, 542; $Q 315,316 ; R$ 176-204, 271-273, 531-534.

\section{Jan. 5, 1762-July 10, 1762 土}

Brief reign. Several legal reforms. Abolition of the Seerot Court of Poliee and of some monopolies. Some improvement in the navy and army. Many talented Frenehmen banished from the country. Mueh diseontent and sedition, ending in a revolution. $b ; A$ ii, $174 ; B \mathrm{v}$, $244,245,251$; $C$ i, 455, 456, 457, 458; $E$ 545-548; $L$ 208-211; O $192-193$. 
Ruler

$+\quad$ Catharine II

An extraordinary character. Ambitions and courageous. Had great "nthusiasur, resolution, natural wit, and insight. Charning in mannor. with houndless good humour, but was hrartless, unscrupulous, and extremely licontions. $a: b ; \quad C$ ii, 137-145; $F+110-412,434 ; G 199,219,220$, 21s; L passim.

\section{一}

Foolish, arrogant, almost insane in his raprir.jolls ereentricitios. Fits of henevolenoe alternated with tyranuy. $a: b ; .1$ ii, 21 ; ( ii, 153-1.56, 165, 1ऽ6; G 2.51; $0.251-255$.
Condition of Country

1762-1796

Important conquests in the south and west. Part of Poland, the Crima, the Kuban, Courland, and a part of the frontiers of Turkey adderl to Russia. Legal reforms regarding the administration of justire. Population and industry increase. Financial exhaustion. Increased intermational prestien. Internal administration net. so good. Poor condition of the army. $b ; c$; A ii, 20s, 211, 215: ( $\mathrm{ii}, 126,127$, 141-149; D ii, 50s; $E$ 558-620; F 409-434; (r 223-245; $L$ passim.

\section{$1796-1801$}

Derline in national prestige. Nation brought to the verge of bankruptry. Doreline in exports of raw matrial. (ircal perversion of justiec. Sinall territory of Cieorgia annoxed 1799. b; $c$; A ii, '26is; (' ii, $160,165-166$; G $251-2.57 ; 02.57-275$.

\section{BIBLIOGRAPHY FOR PRUSSIA}

a. Allgemeine Doutsehe Biographir. 52 vols. Leipzig, 1875-1906.

b. Enegrelopadia Britamniar. 9th and 11th editions.

c. Brocknals. Kombrsations Lexikon.

d. La grinde encyelopédie. 31 vols. Paris, $18 x($ i-1902.

A. Tutrte, Ifermert. History of Prusia. 4 vols. Boston, 1884$1 \mathrm{sigti.}$

B. Ravke, L. vox. Zwölf B̈̈eher Preussiseher Geschichte. 5 vols. Leipzin, 1ธ77-1 779 .

C. Drosisen, I. (i. Geschichte der Preussischen Politik. 14 vols. Berlin and Leipzig, 1568-1856. 
D. Protz, Hans. Preussische Geschichte. 3 vols. Stuttgart, 19001901.

E. Ranke, L. von. History of the Reformation in Germany. 3 vols. London, 1847.

F. Berner, Ernst. Gesehichte des preussisehen Staates. 2 vols. München, 1891.

G. Beer, Adolf. Allgemeine Geschichte des Welthandels. 3 vols. Wien, 1860.

H. Voigt, Friedrich. Geschichte des Brandenburghisch-Preussischen Staates. 2 pts. Berlin, 1867.

$J$. Pierson, W. Preussische Geschichte. Siebente verbesserte und vermehrte Auflage. 2 vols. Berlin, 1898.

K. Lavisse, E. Études sur l'histoire de Prusse. Paris, 1890.

L. RaNke, L. von. Memoirs of the House of Brandenburg and History of Prussia during the Seventeenth and Eighteenth Centuries. Translated. 3 vols. London, 1849.

ReLER

$+\quad$ Frederick I

Vigorous, ahle, masterful. Popular, taetful, good-hearted, but without any high sense of honour. "One of the best scholars in Germany." $a$; $b ; c ; A$ i, 67-68; $B$ i, 104-106; $D$ i, 177 ; $H \mathrm{i}, 152$.

\section{$\pm \quad$ Frederick II \\ (Son of Frederick I)}

Careful and thoughtful; determined in pressing his claims. Not inclined to warfare. Of a calm, pious, and melancholy temperament. Tenacity of purpose was his most noteworthy trait. $a ; c ; A \mathrm{i}, 70-71 ; B \mathrm{i}, 134-135$; $C$ i, pt. i, 66-67; $D$ i, 160, 177; F $60 ; H \mathrm{i}, 164$.

\section{Condition of Country}

\section{0}

Peace and order largely secured for the first time in many years. Turbulent nobles suppressed. Wars agrainst Mecklenburg and Pomerania generally suceessful. The Ulermark again united to Brandenburg. $b ; c$; $A$ i, 68-89; $B$ i, 84-104; $C$ i, 394-402, 456-461, 505, 599-609; $F$ 53-54; $/ I$ i, 136-152, 195, 197.

Further consolidation. Pre-
tentious nobles were humbled. The towns of Berlin and Cologne brought into order and subjection. Neumark aequires. Advantageous diplomatic relations with Mecklenburg, Saxony, and Hesse. Public debt increased. $a ; b ; c ; A \mathrm{i}, 70-72 ; B \mathrm{i}, 109$ 111, 113-134; C ii, pt. i, 50-63, 131-134, 206-213, 273-276, 361$362 ; \quad D$ i, 147-162, 177; $F$ 60$65 ; H \mathrm{i}, 195-196$. 
RULER

$+\quad$ Albert III (Achilles)

(Son of Frederick I)

John (see below) also governed in Brandenburg. Highly tatented as a soldier and politician. Active, adventurous, combative, a lover of splendour and the pleasures of life. Concerning his moral charareter there is a difference of opinion. Ho was perlaps underhanded, tortuous and selfsecking in his mighty ambitions. Much of the actual government of Brandenburg was left to his son John (see bolow). $a ; b ; c$; $A \mathrm{i}, 72 ; B \mathrm{i}, 135 ; D \mathrm{i}, 161-162$, $177 ; E 43 ; F 72 ; H \mathrm{i}, 164-165$.

\section{$\pm \quad$ John (Cicero)}

Considered an easy, comfortable, and mediocre character. Well educated and a patron of learning. Defieient in strength of purpose, but cannot be ealled distinetly weak. $a ; c: A \mathrm{i}, 73$; $C$ ii, pt. i, 519-520; D i, 171, 175; II i, 177.

Minority of Joachim I

Frederick of Anspach, Regent

\section{\pm or + Joachim I}

A man of remarkably strong will. Narrow-minded, taciturn. Not gifted with showy qualities, but succeeded in pursuing a shrewd and definite policy. Noted
Condition of Cotntry

1470-1486 \pm or +

A period of warfare and heavy taxations. The enemies of Brandenburg in Pomerania and Mecklenburg were humbled. Considerable dissatisfaction and disorder, but the disruptive forces were kept fairly well in eheck. A 72 ; $B$ i, 134-141 ; $C$ ii, pt. i, 393$396,397-405 ; \quad D$ i, $162-172 ; F$ $66-72 ; H \mathrm{i}, 164-175,196$.

1486-1499 $\pm$

A comparatively featureless period. Treaty with Pomerania of doubtful significance. Power of eities declined; that of the nobles increased. Government tended towards centralization. Tax on beer. Internal order not very well maintained. $c$; $A$, $73-76 ; B$ i, 143-147; $D$ i, 172 $177 ; F 73-76$; $H \mathrm{i}, 176-179,196$.

\section{9-1502}

Brief period. Nothing of importance.

\section{2-1535}

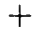

The most notable event was the introduction of Roman law. Its value to the eountry is debatable. Both the nobles and the cities were held in stern subjec- 


\section{RULER}

for his learning, which was of a pedantie nature. $A$ i, $77,78,79$; $D \mathrm{i}, 178,179 ; \quad F 77,79-80 ; H$ i, 179, 190, 194.

\section{$\pm \quad$ Joachim II}

Of mediocre ability, and "no very firm views or eonvictions." Not gifted as a soldier or administrator, but withal a very clever politician. A lover of pleasure, pomp, and lavish expenditure. Took a cultured interest in the fine arts. Not a man of bad intentions. $b ; c ; A \mathrm{i}, 87,101-102$; $D \mathrm{i}, 201-203,242 ; F 94 ; H \mathrm{i}$, 224-226.

\section{\pm or + John George}

A contrast to his father. Extremely vigorous and energetic. An able administrator. Not inclined to warfare. Harsh, tyrannical, perhaps unjust. Simplo and domestic in his tastes. Seems to have been genuinely interested in the welfare of his country. $b ; c ; A \mathrm{i}, 101 ; D \mathrm{i}, 244 ; H \mathrm{i}$, 226.

\section{Condition of Codntry}

tion. Diplomatic position strong. Internal order very well maintained. $b ; c ; A \mathrm{i}, 78-87 ; B \mathrm{i}$, $147-148,152,155,157$; $D$ i, $178-$ 196 ; F 77-88; $H$ i, 179-195, 356.

\section{5-1571}

Reformation spread quietly and was officially recognized in 1539 . Power of the Estates inereased. Bad financial management left the country in debt. Peaceful relations with empire and Smalkald League. Political treaties were wise. $b ; c ; A \mathrm{i}, 87-88,101-102$; $B$ i, $160-166 ; D \mathrm{i}, 197-243 ; F$ 89-97; $H$ i, 206-226. 


\section{RULER}

\section{$\pm \quad$ Joachim Frederick}

Medium grade of ability. Well educated and industrious. Quiet, peaceful, homest, and well intentioned. $A$ i, 10:3; $B$ i, 18.5: $D \mathrm{i}, 220 ; J \mathrm{i}, 822$.

\section{$\pm$}

John Sigismund

Not a man of marked personal characeter or strength of purpose, but possessed, on the other hand, of a fair share of instinctive shrewedness. Indined to outbursts of rage alternating with complaceney. A hard elrinker and prone to idleness, but was probably not without patristic. intention. $b: A \mathrm{i}, 124: B \mathrm{i}, 186$; $D \mathrm{i}, 300 ; 1 / 105 ; 11 \mathrm{i}, 268$.

\section{- $\quad$ George William}

Timid and rapricions. Sought his own ease and comfort. Weak morally and physically as well as mentally. $\quad a ; b ; .1 \mathrm{i}, 12 \mathrm{~s}, 131$; $D \mathrm{i}, 324 ; F 114-115 ; / 1 \mathrm{i}, 265$, $269 ; J \mathrm{i}, 121$.

\section{Condition of Country}

\section{$1598-1608$}

$$
\pm
$$

Few striking events. Establishment of a State Couneil (Geheime Rat) which drew power away from the Estates, which had not succeeded well in preserving order. Somo politieal advance towards the ultimate control of Preussen. $b ; A$ i, $103 ; D$ i, 276 , 27s, 280, 242-291; F 104-108; $I I$ i, 232-240, 349-350; $J$ i, 8285.

Much religious eommotion ending in the recengnition of the principles of toleration. East Pomerania united to Brandenburg through marriage. ()therwise not an important or interesting period. Dispute over Julindi-cleses remained unsettherl. b; $A$ i 124-

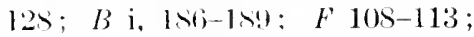
$1 / \mathrm{i}, 240-241,257,263-268,354$.

1619-1640

Very marked decline. Attempt to play a neutral part in the Thirty Years' War met with every disaster. Brandenburg erushed botween Denmark and the Emperor, Prussia between Sweden and Poland. The nation brought to bankruptey, political dissolution, and internal lawlessness. $b ; A$ i, 128-142; $B$ i, 217218; $D$ i, 326-377; F 114-124; $H$ i, 268-2 257 ; $J$ i, 121-132. 


\section{RCLER \\ $+\quad$ Frederick William}

Called the Great Elector. Rugged, vigorous, patient. One of the ablest men of his day. Prudent and careful. A strong, direct will, often violent temper. A liking for strong trink. Not altogether popular or nicely serupulous, but was a man of broad and essentially high ideals. $a ; b$; $c$; $d ; B \mathrm{i}, 378-383 ; D$ ii, 273$288 ; k 218$.

\section{Frederick I}

Ability below the average of kings. Vain, ostentatious, interested only in petty atails. Relied on the judgment of others. llumane, generous, evon rxtratrgant. $b ; A \mathrm{i}, 253-2.5 ; B \mathrm{i}, 4 \mathrm{2}$; $H$ ii, 33-34; $J$ i, 20:3, 20); $K$ $233,243$.

\section{$+\quad$ Frederick William I}

Very parsimonious, industrious, determined, and arhitrary. Not an attractive person, lut was nevertholess an ahlo acluninistrator. ('oarse, brutal, and forocions, appears to have borm devoted to duty, at least as lo saw it. $b: c: a ; A \mathrm{i}, 43: 3,43 \mathrm{~s}, 460$; $J$ i, 233-234; H ii, 43- 14 .

\section{Condition of Country}

1640-1688

Definite and vigorous policy at once established. Army reorganized, disciplined, and rendered effective. Important victories of Fehrbellin and Settin. The Diet suppressed. Agriculture and commerce improved and encouraged. Much desirable immigration. Revenues greatly increased. Acquisition of Eastern Pomerania, Magdeburg, Halherstadt, and Minden. General political inportance greatly enhanced. $b$; $d$ : $A$ i, 145-204; $B$ i, 272-288, $381-382 ; D$ i, $378-420 ; F 126-$ 21s; $G$ ii, 45s; $H$ i, 287-341; K 222-232.

\section{8-1713}

Corruption in the government. Deterioration of the army. Depletion of the troasury. Excessively burlensome taxation. Forrign poliey wak. Prussia gained the status of a kingdom, and some further desirable inmisration took place, but in general the period was one of decline. $b ; A \mathrm{i}, 279 ; B \mathrm{i}, 4.50,460-470$, $482-48.3 ; J$ i, 203-210; $K 232-243$.

\section{3-1740}

$+$

Country enjoyed peace and internal development. Most inportant were tle military and financial improsements. Industrial expansion. Inmigration encouraged and population inreasided. No groit external achievements. Diplomatically Prussia beeame isolated. $b ; A$ i, $375-430 ; B$ i, 451-496; $G$ ii, $459 ; H$ ii, $35-77$. 


Ruler
$+\quad$ Frederick II, the Great
Broad and comprehensive gen-
ius. Great firmmess of will. In-
satiable ambition and love of
power. An indefatigable worker.
Cold, cynical, and arbitrary, but
not devoid of personal atiach-
ments. Attentive to justice and
the welfare of humanity. $a$; $b$;
$c$; $d$; II ii, 1s4-1S5.

RULER

Frederick II, the Great

us. Great firmmess of will. Insatiable ambition and love of power. An indefatigable worker. Cold, cynical, and arbitrary, but not deroid of personal attachthe welfare of humanity. $a ; b$; $c ; d ; I I \mathrm{ii}, 184-185$.

\section{Condition of Country}

1740-1786

Great progress in nearly every department. Serenty million thalors in the treasury at the close of the reign. Army raised to 200.000 well-diseiplined troops. Agriculture improved. Colonies of immigrants established. All kinds of manufactures flourished, espeeially silk. Prussia became for the first time recognized as a power in Europe. At least 100,000 foroignors came into Prussia and allogether the population incrased enormously. "It is not protendexl, however, that Frederick's rulo mado his subjects happy" (Tuttle). $b ; A$ iii, chap. 3,$4 ; B$ ii, $61 ; F 402$ $420 ; G$ ii, 460-461; $K$ 273-302.

\section{BIBLIOGRAPIIY FOR AUSTRIA}

a. Algemeine deutsehe Biographie. 52 vols. Leipzig, 1875-1906.

b. Enevelopedia Britannica. 9th and 11 th editions.

c. Wrizbacil. Biographisehes Lexikon. 60 vols. Wien, 1856-91.

d. Brockuats. Konversations Lexikon. 2 vols. Leipzig, 1906.

e. La grande enryelopédie. 31 vols. Paris, 1811-6i2.

A. Coxe, W. Ilonse of Austria. 3 vols. 1847. A.4. 5 vols. London, 1s:0.

B. Legere, Lorts, P.MI. A IIistory of Austro-Hungary from the Earliest Times to the Year 1sis. Trans. from the French by Mrs. Birkbeck Hill. Preface by E. A. Freeman. London, 1889.

C. Huber, Alfoss. Geschichte Österreichs. 5 vols. Gotha, 188596.

D. Menzel. Wolfanas. The History of Germany from the Earliest Period to the Present. Time. Trans. from the fourth German edition by Mrs. (ieo. Horrocks. 3 vols. London, 1876-79.

E. Wricilt, J. H. (Editor). A History of All Nations. 24 vols. Philadelphia, 190\%.

F. Grindey, Antox. History of the Thirty Years' War. Trans. by Andrew T. Brook. 2 vols. N. Y., $1 S \$ 4$. 
G. Beer, Adolf. Allgemeine Geschichte des Welthandels. 3 vols. Wien, 1860.

H. Prutz, Hans. Staatengeschichte des Abendlandes im Mittelalter. 2d. vol. Berlin, 1887.

$J$. Krones, Franz. Handbuch der Geschichte Oesterreichs mit besonderer Rücksicht auf Länder-, Volkerkunde und Culturgeschichte. 4 vols. Berlin, 1876-79.

$K$. Ranke, Leopold von. History of the Reformation in Germany. 3 vols. London, 1905.

L. Mayer, Franz M. Geschichte Oesterreichs mit besonderer Rücksicht auf das Culturleben. 2 vols. Wien und Leipzig, 1900-01.

M. Whitman, Sidney. Austria. New York, 1889.

RULER

$+\quad$ Rudolph I, of Hapsburg

(Emperor)

Physically and mentally a grand figure in the age in which he lived. Noted for his practical wisdom, prudence, and sense of justice. $a ; b ; c ; A \mathrm{i}, 53,58$; $C$ ii, 3.

$+$

Albert I

Able, energetic, brave, firm. Excessively ambitious. Was avaricious, rapacious, and extremely cruel, but is eredited with an austere frankness and with domestic virtue. $a ; b ; c ; A$ i, 79; $C$ ii, $9-10 ; D$ ii, $85 ; H, 144$; $L$ i, 289, 298.
Condition of Codntry

1276-1291

Austria, Styria, and Carniola aequired through force of arms by Rudolph of Hapsburg, who had already been elected Emperor. The most important fact is that order and tranquillity were restored. $A$ i, $57 ; C$ ii, $3-7 ; D$ ii, 27 ; $E$ ix, 311,$314 ; H 131-$ $140 ; L \mathrm{i}, 117,174$.

\section{3-1308}

Internal order vigorously maintained. Tyranny was felt ehiefly by the nobles. Robber barons were suppressed. Burghers, the surburban class, and serfs were catered to, and received benefits. Most of the interest centers around events outside of Austria, and the efforts of Albert to strengthen the then disorganized Empire. $b ; A$ i, $80 ; B 644 ; C \mathrm{ii}$, $51-62,95,100 ; D$ ii, $85 ; E$ ix, 318; $H$ 144-151; $L$ i, 289-292.

1 The government of Rudolph and his son Albert overlapped for eight years. 
RULer

\section{Frederick and Leopold} \pm Frederick " the Handsome"

Mediocre ability, brave, amiable, and not deficient in accomplishments ; mild, benerolent, and honourable. $A \mathrm{i}, 82 ; A A \mathrm{i}, 144$; $D$ ii, 116.

$$
\pm
$$$$
\text { Leopold }
$$

Bold, hardy, energetic. Possessed considorable talent for warfare, but was a restless, turbulent spirit, lacking in juclgment. He seems to have fallen into a state of melancholia after the battle of Muhldorf, 1322, and died 1:326 in a "fit of frenzy." $1 \mathrm{i}, 83,102$; A A, i, 126, 144, 149; L i, 300 .

\section{Albert and Otto}

\section{$+\quad$ Albert "the Wise "}

A distinetly superior ruler. High talents as a soldier and arlministrator. Learned, benignant, humane; extremely poptelar with his subjerts. A i, 116 , 11s: B, 144, 145; $C$ ii, 186,194 ; I) $\mathrm{ii}, 126$.

\section{Otto "the Gay"}

An obseure charaster, but little mentioned. Died Feb. 16, 1339, aged $37 . \quad 1 \mathrm{i}, 103$.

\section{$+\quad$ Rudolph IV}

This prince was called by four different surnames, — "The silent," "The Magnifirent," "The Learned," and "The Founder." Each one, says Kroner, "rhal"acterized one of his qualities." He is generally credited with high and precocious talents and a knowledge of the arts and sciences.

\section{Condition of Country}

\section{8-1330}

A period of warfare with the Swiss and Bararians not characterized by suceess or by important results in any direction. On the whole the Austrians appear to have been the losers. The territorial gains were the county of Pfirt or Ferrette (1324), and the domains of Kyburg (1326). In 1315 the lorest towns threw off the Austrian roke. A i, S1-102; B 113, 614; C ii, 113-148.

\section{0-1359}

Increase in territory and external strength. Torritorial gains: Breisach, sohafinsen, Rheinfollen, Néubure, Rappenchwyl, and the duchy of Carinthia. lusses: Lucerno, Cilaris, and Zere. Vienna and Klagenfurt, the capital of Carinthia, recerived new muniripal rorles. Suppression of "Trial by Combat" in Carinthia. A i, 106, 109; I; 144, 145, 644; $C$ i, $15.5-194,403-404$.

\section{9-1365}

Brief but important reign. Austria proper gained the large territory known as the Tyrol, and became more independent of the Empire. Internal administration was vigorous. Trade and manufaetures were encouraged. Taxes imposed on wine and beer. University of Vienna and Cathe- 


\section{R OLER}

Considerably in advance of his times. Was secretive in his plans, and perhaps underhand in his methods. Is believed to have falsified charters to further his independence of the Empire. Died aged 25. $A$ i, 118, 122; $B, 145$; C ii, 288; $J$ ii, 133 .

\section{Albert and Leopold}

$\pm$ Albert III

Plaeid and peaceful disposition. A slow, serious person not defieient in firmmess or understanding. Attached to the pursuit of literature and the exact sciences. Popular with his subjects. A i, $123,140,141$; $C$ ii, $304-305 ; L$ i, 328 .

\section{$\pm \quad$ Leopold}

Brave, ambitious, impetuous; devoted to warfare, but his plans were not well thought out. Ilis character described as rapacious. (Died in 1386, aged 35.) $4 \mathrm{i}$, 123; $G$ ii, 305; $L$ i, 328 .

\section{$\pm \quad$ Albert IV and William Albert IV}

A rather vague and doubtfully outlined character. Was alled by some "the Patient." Had a reputation for piety and devotion to religion and oceult scienees. Also undertook a dangerous pilgrimage to Palestine, which gained for him much romantic admiration. Died in 1404. $A A$ i, 203, 204; $B$, $149 ; C, 323 ; J$ ii, 322 ; $L$ i, 347 . William "der Freundliche"

An obseure person. Said to have been popular and to have had knightly qualities. Died in 1406. $J$ ii, 192, 223.
Condition of Country

dral of St. Stephen founded. $A A$ i, $172,174,175 ; B$ 147-14S; $C$ ii, 260-288, 403-404; $J$ ii $132-152 ; \quad L 320,321,412,413$, $445-449,451$.

1365-1395 $\neq$ or +

A period of external wars of doubtful outcome. Internal conditions in Austria peaceful. Considerable waste of resourees. Gains in territory: (1367) Breisgau, (1374) the property of the counts of Gorica in Carniola, (1379) the Bailiwick of Suabia, (1381) Hohenberg, (1382) Trieste. From 1379 to 1356 territories of the House of Hapsburg were divided between Albert and Leopold, Austria alone falling to Albert. A i, 124, 125-130, 140 ; $G$ ii, 2S5-303, 316, 321 ; $L$ i, 327331 .

\section{5-1406} $\pm$

A brief and unimportant period. Dissensions among Hapsburg branches. Styria, Carinthia, and Carniola administered by William, who claimed also Austria. An agreement was reached that botl should rulo jointly (1404). Some parliamentary alvance (die Stande). $B$ 149 ; $C$ ii, $322-324,396,397,405-$ 407 ; J ii, 217-223; $L$ i, 346-349. 


\section{RULER}

Minority of Albert $\mathrm{V}$

Leopold IV and Ernest. Regents

\section{$\pm \quad$ Leopold}

Of no great ability and little virtue. Quarrelsome and selfseeking. Outwardly polished and a patron of learning. His character has perhaps been unduly slandered. $A A$ i, 206-207; $B$, 105 ; $C$ ii, 409-20; $J$ ii, 227.

\section{$+\quad$ Ernest der Eiserne, younger} brother of Leopold IV

Strong, positive, able, and excessively ambitious and rovetous. $A A$ i, 206-207; $B$ 150; $J$ ii, 227,$261 ; L$ i, 349.

\section{$+\quad$ Albert V (Emperor, 1438)}

Able administrator. A firm, serious, dignified, lofty type of man. Simple in his tastes. Taciturn nature. Maguanimous, highly esteemed. $A \mathrm{i}, 171 ; B, 150 ; C$ ii, $421 ; J$ ii, 320 .

\section{- Minority of Ladislaus " Post- humous "}

Control of the government divided. Ladislaus was a weak youth and died aged serenteen.

\section{Condition of Codntry}

\section{6-1411}

A period of discord. Lawless nobles and banditti devastated the eountry. "Sometimes the power of Leopold was predominant, sometimes that of Ernest; and the aim of both was to enrich themselves by exactions and impositions before the young Albert could assume the reins of government." $A A$ i, 206-207; B 150; $C$ ii, $410-418,420 ; J$ ii, 224-227; $L$ i, 349 .

\section{1-1439}

Change to tranquility and prosperity. Security for life and property. Turks driven from Hungary, 1435. Bohemia and Itungary came to the Hapsburgs through marriage of Albert $\mathrm{V}$ with Elizabeth, heiress of these eountries. $A$ i, $147 ; B 150 ; C$ ii, $421 ; J$ ii, $279,312-320$.

\section{9-1457}

Austria, Hungary, and Bohemia may theoretically be considered as united in this reign under a single crown worn by the youthful Ladislaus. Practically there was no union. Various parties and factions were at war with each other. The period not without glory from the important victories gained by Hunyady and Ladislaus of Poland against the Turks. $b ; d ; c ; A A \mathrm{i}, 243-263$; $J$ ii, 321-377; $L$ i, 362-370, 449450 . 


\section{RULER}

Frederick III (Emperor), and his younger brother Albert

In 1458 Albert was granted Upper Austria, Frederick, Lower Austria. Vienna was to be the joint residence.

$\pm$

\section{Frederick III}

Slow, persistent, phlegmatic. Lacked energy. His disposition peaceful. Sedentary in his tastes. A lover of learning. Stubborn and selfish. His private life was chaste and abstemious. Consistently devoted to the aggrandizement of his family. $b ; A \mathrm{i}, 321$, 335,$384 ; D$ ii, $183 ; E \times$ x, 198 ; $J$ ii, $389,489-491 ; K 150 ; L$ i, 390-391.

$\pm$

Albert

Ardent, impetuous, restless, rash, gay; excessively ambitious, prodigal, fond of war. $A A$ i, 301 ; $J$ ii, $337,352,382,392$.

\section{$\pm \quad$ Frederick III (Emperor) See above.}

\section{Condition of Codntry}

\section{7-1463}

On the death of Ladislaus, Hungary and Bohemia separated from Austria. This period was occupied by party warfare between the brothers Frederick and Albert. $b ; A A$ i, 325-333; $J$ ii, $377-392$; $L$ i, $372-375$.

1463-1493
The Turks several times in-
vaded Carniola and Styria. In
1485 the Austrians were defeated
by Matthias Corvinus, king of
Hungary, who made Vienna his
capital. IIouso of Austria ag-
grandized its power by the mar-
riage of Maximilian with Mary,
heiress of Burgundy. Though
often considered a weak and un-
fortunate reign, there is a good
deal to be said on the favorable
side. Austrian political influence
was considerably augmented.
Something was accomplished
towards suppressing lawlessness


Ruler

\section{$+\quad$ Maximilian I}

Tain and rersatile. Called "the last of the linights." Brilliant, eloquent, learned, ambitions, and a hard worker, but too impulsive and erratic. $H_{0}$ is by some charged with duplicity. lle was amiable ant popmlar. 1 pieturesque figure. (Ono of the best remembered of the Hapslumes. $a ; b ; c ; A$ i, 393, 394-397; $C^{2}$ iii, 464; $K, 11 \mathrm{~s}$.

$+$

Charles V

Sagaciotis, vigorous, inordinately ambitious. Murh duplicity in his eharacter, seltish, cold. "His virtues were nogative rather than positive." References, see spain.

$+$

Ferdinand I

Well educated and very industrious. Though not endowed with brilliant talents, is generally considered a superior ruler. Amiable, frank, just, soher, and pure in his domestic life. Inclinent towards peace and a moderate policy. $a$; $b ; \quad c ; A$ ii, 16 ; B, 259; C iii, 480; iv, 196, 201, 202 ; $L$ ii, 59-60.

\section{Condition of Country}

and furthering justice. Suabian League benefiter Austria. Taxation was especially burdensome. Considerable building. $b ; A A \mathrm{j}$, $3.39-3.58,367-369,376-381 ; J$ ii $425-435,4.51-471 ; 80-492 ; L$ i, $376-391,450,453,513$.

\section{$14931519+$ or \pm}

Austria enlarged and consolidated. Estahlishment of law and order. Reforms and improvements in the internal administration, in the army and navy, and police rogrulations. Foreign dipomacywak. Financesdeclined. 'Taxation high. $\quad b$; $A$ i, 376, 394; B 251-25\%, 645; C iii, 450-453, $454,459,489 ; \quad L$ i, 394-399, 451, 45.3 .

\section{$1519-1521$}

Brief period. No important changes. $\quad C$ iii, 479-491.

\section{1-1564}

Period of the Reformation. Uprisings in Tyrol, Hungary, and Bohemia, which were suppressed. Civil wars in Transylvania, which country was lost. Finances derlined. Possessions extended hy soveral important districts. Army strengthened and condition of the peasantry imploved. Industry grew. $A$ ii, $494,495,499,517,519,523,526$; $A A$ ii, 229, 234-235; B 257; $C$ iii, 504, 511, 513, iv, 199, 202203, 206, 207, 209; $L$ ii, 1-60, 296-300, 312 .

1 Probably rated too low in "Heredity in Royalty." 
RULER

$+$

Maximilian II

Wise and prudent. Talented, liberal, and amiable. A model husband and father. An excellent character in many ways, but was perhaps lacking in firmness. $a ; b ; c ; C$ iv, 248, 249; $J$ iii, 287-2S8; $L$, ii, 76 .

\section{Rudolph II}

In youth he evinced good capacity and considerable learning. Mild, indolent and pleasure-loving. Increasing melancholia and a penchant for drink terminated in mental weakness during the last fourteen years of his life. Resigned his erown. ${ }^{1} a ; c ; A$ ii, $129 ; B, 261 ; C$, iv, 284-286, 359-360; $D$ ii, $308, E$ xii, 57,71 ; $J$ iii, 292-294 ; $L$ ii, 109.

\section{Matthias}

In his youth active, restless, and ambitious. No great ability. Unreliable and intriguing. During his latter years, which romprised the period of his reign, he showed little interest in affiairs of state. $a ; c ; A$ ii, $B, 263 ; C$ v, $46 ; E$ xii, $151,160,164 ; J$ iii, 294-295; $L$ ii, 109-110, 112.

\section{$\pm \quad$ Ferdinand II}

Diligent, and well-meaning, but narrow-minded. Patient and rlevout, but tyrannical and bigoted, perhaps cruel. Private life praiseworthy. Extravagant in

\section{Condition of Country}

1564-1576

A period of peace, law, strength, order and justice. Austria not successful in the question of Poland. Cities were very flourishing, lower classes prosperous. A ii, 57; $A A$ ii, 286, 295, 315, 337; $C$ iv, 249; $J$ iii, 287-288; $L$ ii, 60-76, 296, 300 .

\section{6-1611}

Many eivil and religious uprisings. Internal confusion. Weakness and corruption in the goverument. Agrarian difficulties and peasant's war. $A$ ii, $62-130$, $109,111,113,115,121,123 ; B$, $261 ; C$ iv, $296,363,365,476-555$; $J$ iii, 288, 295-297, 314-319, 322352 ; $L$ ii, $77-109$.

I The grade (5) which was accorded Rudolph II in "Heredity in Royalty" has been eriticised. This was given as a conservative way of eseaping the difficulty of wcighing natural ability against indolenee and late mental unbalance. As a ruler he was certainly weak. 


\section{RULER}

the use of money. $a ; b ; c ; A$ ii, 298, 299; $B$ 264; $E$ xii, 171, $182 ; \quad F$ ii, $250 ; J$ iii, 505-506; $L$ ii, $172-173$.

$\pm$

Ferdinand III

Of mediocre ability. Learned and fond of the arts, but lacking in strength and decision of character. Mild, frugal, and extremely just. $a ; b ; c ; A A$ iii, $25.5 ; B$ 266; $C$ v, 516-517; $D$ ii, 375; $E$ xii, $294 ; F$ ii, 257 ; $J$ iii, $551-$ 552.

\section{$\pm \quad$ Leopold I}

A learned recluse. Diligent in application to details, hut lacking in depth and decision. Private and domestic virturs praiseworthy. Well-meaning and extremely charitable. $a$; $b ; c$; $A$ ii, $515 ; A A$ iii, 479 ; $E$ xiii, 157 ; $J$ iii, $563-565$; $L$ ii, 1 S3.

\section{$+\quad$ Joseph I}

Clear, active, and vigorous intellect. Amiable, generous, tolerant, and humane. Tastes artistic and scientific. $a ; c ; A A$ iv, $1-4,117,118 ; B, 342 ; E$ xiii, 303 ; $J$ iii, 563-565; $L$ ii, 236.

\section{Condition of Codntry}

pleted. Many intelligent subjects emigrated. Loss of personal liberty. $A$ ii, 161-291; $A A$ iii, $189-190 ; D$ ii, $375 ; E$ xii, 172-173, 1S3, 202, 209, 215, $216,261,294$; $G$ ii, 441 ; $J$ iii, $402-405,426-506 ; \quad L$ ii, 121173,313 .

1637-1657

Establishment of internal peace. Constitutional progress. Frugal financial mauagement. Dechine in international prestige. Loss of Alsace. Considerable depopulation. $b ; A$ ii, 302, 305, 308, 309 , $311,314,317,319,322,341-344$; B 266, 341, 344; C v, 517, 616$617 ; E$ xii, $321-322 ; J$ iii, $516-$ 547, 551-561 ; L 177-183.

\section{7-1705}

By the Peace of Carlowitz Austria acquired Turkish Hungary, Slavonia, and Transylvania. Improvements in the administration of justice and in the army. Financial depletion. Some dechine in trade. $b ; d ; c ; A$ ii, 382, 571,588 ; $E$ xiii, 157 ; $G$ ii, $442-$ 443 ; $J$ iii, 562-6SS ; $L$ ii, 274.

1705-1711

Brief reign. War of the Spanish Succession was on. Empire showed strength in its inner and outer activities. $a ; b ; c ; A$ iii, $3,49,77$; $E$ xiii, 303 ; $L$ ii, $230-$ 237,325 . 
RUler

Charles VI

Stupid and obstinate. A poor ruler, deficient in intellectual grasp. Cold, jealous, suspicious, unreliable, though probably wellintentioned. Pious; fond of the fine arts. $a ; c ; A$ iii, 113, 240 ; $D$ iii, $16 ; L$ ii, 251.

$+$

\section{Maria Theresa}

Brave, able, very iudustrious, economical. Kind, eharitable. A good wife and mother. Strict, even illiberal in her prejudices. $a ; b ; c ; A$ iii, 482; $B$ 381; $D$ iii, 48 .

$\pm$ Joseph II

A very strange character. Restless, brave, ambitious, mentally, alert, and well-informed,'but was impractical and visionary. An incompetent general. Benevolent, generous, and anxious to bring about reforms. Austere but amiable. Praised for his domestic virtues. His chief vice
Condition of Codntry

1711-1740

Peace of Passarowitz (171S) brought increase of territory, which, however, was of doubtful advantage. Events of 1733-1739 unfortunate for Austria. By the Peace of Belgrade much territory given back to the Turks. Finances and condition of the army reduced to a deplorable state. Weak diplomacy. Some increase in trade and industry. At the close of this reign Austria had sunk to a point of extreme weakness. $b ; e ; A$ iii, 108, 110, $135,145,167,177,189,199,219$, 221,$225 ; D$ iii, $15 ; E$ xiv, 188 ; $G$ ii, 443, 444; $L$ ii, 244, 231 .

The various portions of the kingdom unified and centralized. Austria gained slightly in territory and greatly in prestige. Industry, commerce, and agriculture improved. $a ; b ; c ; d ; e ; A$ iii, $483 ; \quad B$ 329-381; $G$ ii, 433, 445; $447,453,454 ; \quad L$ ii, 421-433, $545-555$.

1780-1790 $\pm$

Neither progress nor decline is clearly marked. A period of internal agitations and foreign wars. The reforms were too drastic to meet with success. Some improvement in agriculture, roads, and canals. Some dearly bought success against the Turks. The diplomatic position 
$\mathrm{R}_{\text {ULER }}$

was duplicity. $a ; b ; c ; d ;$ of Austria was weakened to the $A$ iii, 486, 541-542; $B, 393 ; D$ adrantage of Prussia. $b ; d ; e$; iii, $84 ; L$ ii, $473-474$.

\section{$+\quad$ Leopold II}

A dever, cautious politician. Intelligent and energetic. Kindhearted and just. Is said to have berm a libcrtine. $a ; b ; c ; \quad 1$ iii, 552, 553, 579; $B, 393-399$.
$A$ iii, 488, 491, 494, 499, 510, 521, 522, 531, 533, 543; B 382-393; $D$ iii, 86,90 ; ( ${ }_{i}$ ii, $433,445,446$, $447,450,451$, 450; $L$ ii, 449-474, $552-553 ; 11266-273$.

\section{0-1792}

Brief period. Opinions vary as to its simnificance. Restoration of law and order by conciliations. Perhaps a woaliened dipIomatic position. Private liberty somewhat curtailed. $a ; b ; d$; (; 1 iii, 545, 547, 5.52, 562, 579; $B \quad 395-400 ; \quad L$ ii, 474, 481; II $274-278$.

\section{BIBLIOGRAPIIY FOR TERKEY}

a. Encyelopedia Britannica. 9th and 11 th oditions.

A. Creasy, Sir EDWARD. History of the Ottoman Turlis. London, 1877.

B. Freflax, E. A. The Ottoman Power in Europe. London, 1877.

C. Vox Hammi-Pircistan, J. Geschichte des Osmanischen Reiches. 4 vols. Buda-Pest, 1si34-35.

D. The Cambrilge Modern IJistory. Edited by (A. W. Ward, G. W. Prothero, stanley Leathes, planned by the late Lord Arton). 13 rols. Cambridge, England, 1902-11.

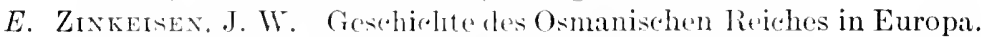
7 vols. IIamburg and (iotha, isto-633.

F. LA Joxquiere, A. IIstoric de I'Empire Ottoman. Paris, 1881. G. Lane-Poole, Stanter. The Story of Turkey. london and New Tork, 1900 .

H. Jorris, N. Geschichte des Osmanischen Reiches. 2 vols. Gotha, $190 \mathrm{~S}-09$.

\section{$+\quad$ Osman (Othman I)}

Brave, resolute, subtle. An able warrior and popular leader. Highly eulogized for miliness,

\section{$1288-1326$}

Foundation of the Ottoman power. Dominion enlarged, partly at the expense of rival 
RUler

humanity, and justice, although he is reported to have murdered his uncle. $a ; A, 2 ; B, 103$.

\section{Orkhan (Urkhan)}

Great organizer. Superior military and political talents. "A brave warrior and upright prince." Free from eruelty. $a$; $A, 16 ; B, 103 ; C$ i, 142 .

\section{$+\quad$ Murad (Amurath) I}

Able warrior and politician. In the main upright, though eruel at times. $a ; 1,24 ; C \mathrm{i}, 1 s 0$; F, 131-132.

\section{+ Bayezid (Bajazet) I, the Thunder- bolt}

An able general, distinguished for the rapidity oi his motements. Cold, cruel, licentious, and a drunkard. $a ; 2,24,37,47$; $B, 110 ; C \mathrm{i}, 182 ; H \mathrm{i}, 266$.

\section{Interregnum}

\section{+ Mahommed (Muhammed) I}

Accomplished, just, and magnanimous. A patron of literature and poetry. $a ; A, 54.59$; $C$ i, 305 .

\section{Condition of Codntry}

chieftains, but principally from the Greek Empire. $a ; A$ 8; $B 103$; $C$ i, 79-80; $H$ i, 149, passim.

\section{6-1359}

Extensive conquests from the Greeks in Asia Minor. Army of Janissaries founded, also many mosques, colleges, and other public institutions. $a ; A 16$; $B$ 103; C i, 117-135.

\section{9-1389}

Prosperity and victories. Conquest of Roumelia and Bulgaria. $a ; A 22,26 ; B 105 ; H$ i, 215, passim.

\section{9-1402}

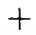

Conquest of the sreater part of Asia Minor and a considerable portion of Erecer. Victory over allied Christians at Nicopolis. Defeated by Tamerlane at Angora. $a ; A 33,36 ; B 110,111 ; C$ i, $182,248-250$.

\section{2-1413}

Kingdom weakened in the struggles of rival princes. $A 50$; $B 113 ; C$ i, 265.

1413-1421
Turkish dominion again con-
solidated and restored. Tho
European power of the Ottomans
made but small adrance. Con-
iderable building of mosques,
etc. $a ; A 54-59 ; B 113 ; C$ i,
$302,305$.




\section{RULER \\ + or \pm Murad (Amurath) II}

An able, just, and humane ruler. "His character was as noble as it was commanding." $a ; A, 66 ; C$ i, 350-351; $G, 101$.

\section{+ Mahommed II, the Conqueror}

Not only a great soldier and statesman and organizer, but a master of many languages. Was notorious for his eruelty, lust, and faithlessness. $a ; A 75$; $B 114 ; C$ i, 173-175.

\section{$\pm \quad$ Bayezid (Bajazet) II}

Unambitious and peace-loring. Simple in his habits. Austere in his derotions. Fond of speculative philosophy. His virtues were much praised. Deposed by his son Selim. $a ; A 122 ; B$ $125 ; C$ i, $623-624,684$.

$+$ Selim I

A warrior of high ability. Remarkable for his political sagacity and literary talent. Extremely cruel and bloodthirsty. Cared little for pleasure. $a$; $A 127$; B 126; Ci, 691-694, 801; $D$ i, $90 ; H$ ii, 316 , passim.
Condition of Country

1421-1451

Turkish power advanced. Thessalonica added. In the wars with Hunyady victories balanced defeats. $a ; B 125 ; C$ i, 575-578, 594 .

1451-1481

Marked advance. Famous capture of Constantinople. Servia and Bosnia reduced, also Trebizond, Karaman, the Crimea, and many lands of the Greek Archipelago were added to the Turkish dominion. Much building of schools, mosques, etc. $a ; B 125$; $C$ i, 575-578; $594 ; H$ ii, 1 , passim.

\section{1-1512}

A general lethargy. Practically no advance against the Christians. Many internal disturbances. No special decline. A single naval victory. Apparently no lack of finances. More building. $a ; A 121,125 ; B$ 125 ; $C$ i, $624,647,649,684,685-$ 687.

\section{2-1520}

Empire doubled in extent. Conquests of Kurdistan, Syria, and Egypt. Inerease in the navy. $a ; B 125 ; C$ i, $799 ; H$ ii, 327 . 


\section{RULER}

\section{+ Suleiman I, the Magnificent}

One of the ablest rulers of his time. Brilliant genius in war and government. Extremely just. Free from vices. Warmhearted and sincere. He is, however, accused of undue severity in ordering the execution of many of his officers and relations. $a$; $A 211 ; B 127$; $C$, ii, 351$353 ; D$ i, 92 ; $H$ ii, 342, passim.

\section{Selim II}

Weak in intellect. Extremely degraded. Idle, sensuous, addieted to drunkenness and the coarsest vices. Cruel and treacherous. $a ; A 272 ; B 130$.

\section{- Murad (Amurath) III}

"Weak and sensual, as well as cruel, but his mind was not altogether without cultivation." $\mathrm{He}$ ruled in name only. $a ; A 225$; $E$ iii, 385-387.

\section{Mahommed III}

Feeble ruler, devoted to pleasure. Weak-minded, jealous, siekly, voluptuary. Put his nineteen brothers to death. $a ; A$ 231-38; $C$ iii, 667-668.

\section{- $\quad$ Ahmed I}

Irresolute, weak, selfish, and indolent, though moderate and good-natured. Too much a lover of pleasure. $A$ 238; $C$ ii, 766; $E$ iii, 733.
Condition of Country

1520-1566

Turkish Empire attained the summit of its power and glory. Conquest of Hungary, Transsylvania, Rhodes, and a large portion of Armenia. Much building of mosques, bridges, and roads. $A 156,181,209 ; B 127$; $D$ i, 92 ; ii, 128 ; $H$ ii, $342-453$.

1566-1574

Neither arlvance nor declino clearly marked. Cyprus and Tunis were won. The Turks met an overwhelming defeat in the famous naval battle of Lepanto. $a ; B 130 ; D$ iii, 136 .

\section{4-1595}

Rapid deeay. Insubordinatiou in the army. Transylvania, Moldavia, and Wallachia rose in revolt. $a ; 224,228,229 ; E$ iii, $389,397,559,572-579,775-$ 783.

\section{5-1603}

Inglorious reign. Decline. Unsuceessful war in Persia. Revolts in the army. A victory over the Austrians and Transylvanians, but nothing came of it. $a ; A 224-237$; $C$ ii, 667670 .

\section{3-1617}

Further loss of national prestige. $a ; A 241$. 
RULer

\section{- Osman (Othman) II}

A bold, ambitious youth with little political wisdom or military skill. "Very cruel and hardhearted," but not sensual. A 242-243; $E$ iii, 734.

\section{Mustafa I}

An imbecile. $a ; A, 242 ; C$ ii, 770,813 .

\section{$+\quad$ Murad (Amurath) IV}

Courageous, vigorous, decisive. Passionate, tyrannical, eruel, and a drunkard. $a ; A 246 ; B 137$; $C$ iii, 137, 206-211.

\section{- Ibrahim}

Weak and sensuous voluptuary. Cowardly, selfish, eruel, brutal. a; $A 259$; $B$ 137; $C$ iii, 253256 .

\section{- Minority of Mahommed IV}

(Kuprili, grand vizier 1656-1661, followed by his son Fázil)

Both were men of great ability. $a ; A 272 ; C$ iii, 523-524, 689, 690.

\section{- $\quad$ Mahommed IV}

Weak, selfish, not especially eruel. Devoted to hunting. Had some literary tastes. Lazy and good-natured. Just and clement. $A 277,294,299 ; C$ iii, $614,615,690$.

\section{Condition of Country}

\section{8-1622}

Loss of territory which was restored to Persia. Revolt of the Janissaries and murder of Osman. $a ; A 242 ; C$ ii, 776777, 799-809.

\section{2-1623}

Miseries, disorders, intrigues, robberies, and murders. $A 244$; $C$ ii, 815 .

\section{3-1640 +}

Order and discipline reëstablished. Turkey again restored to something of its former glory. Revenues were honestly administered. Bagdad retaken from the Persians. Reforms in the army. $a ; A$ 250-253; $C$ iii, 210; $E$ 260-262.

\section{0-1648}

All the evils that had been curbed for a time broke out afresh. Treasury depleted. Taxes increased. $a$; A 259-261; $C$ iii, 252.

\section{8-1663}

Disorders and evils until 1656 , when Kuprili came into control. After this progress and prosperity. Order established. Tenedos, Lemnos, taken from the Venetians $a$; $A$ 273, 276, 277; $C$ iii, 475,482 , 523-524.

\section{$1663-1687$} $\pm$

Island of Candia captured by the Turks, under the leadership of Fázil Ahmed, but after his death, in 1676, disaster followed disaster and many cities were lost. Naval power declined. $a ; A$ $283,290,294-296 ; B$ 148; $C$ iii, 613, 787-\$03. 


\section{Roler}

\section{Suleiman II}

Dull, though well-meaning. Devoted himself to petty details in reorganizing the army. Not idle or sensual. Pious, credulous. A 301 ; C iii, 806.

\section{- $\quad$ Ahmed II}

Feeble, melancholy, and pious. Had little influence. Mild and well-meaning, fond of literature. $a ; C$ iii, 847, 872.

\section{Mustafa II}

Naturally intelligent and cultivated. Started with firmness and good intentions. Not a strong character. In his latter life sank into ease and sensuality. Was deposed. $a ; A$ 323; $C$ iv, 74 .

\section{\pm or - $\quad$ Ahmed III}

Mediocre, peaceful character. Lover of ease and luxury. Ruled by his grand viziers. $a ; A 349$; $C$ iv, 268.

\section{Mahmud I}

Little intellect. No influence. Mild in disposition, quiet in his tastes. Humane and affable. $a$; $C$ iv, 481 ; $F 368$.
Condition of Codntry

\section{7-1691}

Mutiny and pillage by the Janissaries. Turks lost the greater part of Hungary, but recovered Servia and Belgrade. $a$; A 301-304; $C$ iii, 809-811, $835,838,841,843$.

\section{1-1695}

Defeats, domestic insurrection, pestilence. $a ; A 310-11$; $C$ iii, $848,859,861,862,869 ; F 343$.

\section{5-1703}

First part of the reign successful against the Austrians, last part disastrous. Further defeats, loss of territory and international prestige. Peace of Carlowitz, 1699, marked the final dechine of the Ottoman power. $a$; $A$ 312-324; $B$ 155; $C$ iii, $892,893, \quad 913-926$, iv, 133; F 343-347.

\section{3-1730}

Suecess against Peter the Great at the Pruth. Recovery of Azoph and Morea balanced loss of territory in the disastrous war with Austria. Internal conditions were fairly prosperous. $a$; $A 349$; $C$ iv, $125-129,133,164-$ 166, 266-268.

\section{0-1754}

A fairly prosperous reign. Success against the Austrians. Belgrade, Orsova, with portions of Servia, Bosnia, and Wallachia, restored to Turkey. Inereased international prestige. $a ; A$ 375 ; $C$ iv, 367-368; $F 363$. 
RULER

- Osman (Othman) III

Inferior ability. Changeable, passionate. Left the direction of affairs to others. $a ; C$ iv, 483, $497 ; E$ v, 847.

\section{- Mustafa III}

Mediocre ability, and much industry. Well-intentioned, but hasty and headstrong. Devout, austere. $A 380 ; C$ iv, 648-649; $E \mathrm{v}, 848-852$.

\section{- Abd-ul-Hamid}

Weak and insignificant ruler. Left the direction of affairs to his vizier. $A 409$; $C$ iv, 650, 653.
Condition of Country

1754-1757

Brief reign. No important changes. $A 377$; $C$ iv, 483-497; $E \mathrm{v}, 847-848$.

\section{7-1773}

First part of the reign filled with reforms and not unprosperous. Last part disastrous. Russians took Crimea, Moldavia, Wallachia, in $1770 . b ; A 378$; $C$ iv, $497,503,543-545 ; E$ v, 848-852.

\section{3-1789}

Humiliating peace of Kainardji in 1774. In the last part of the reign Turkey suffered further defeats by the Russians and Austrians. $b ; A$ 415; $B$ 161; $C$ iv, 655-662.

\section{BIBLIOGRAPHY FOR SCOTLAND}

a. Dietionary of National Biography. 66 vols. London, 1885-1901.

$b$. Encyclopædia Britannica. 9th and 11th editions.

A. Burton, John H. History of Scotland. New edition revised. 9 vols. and index. Ediuburg and London. 1873.

B. Mackintosh, John. The History of Civilization in Scotland. New edition. 3 vols. 1892-95.

C. Brown, P. Hume. History of Scotland. 3 vols. Cambridge, 1899-1909.

D. Lang, Andrew. A History of Scotland from the Roman Occupation. 4 vols. Edinburgh and London, 1900-07.

$+\quad$ Robert Bruce

Able warrior and administrator. Brave, popular, liberal, and pious. $b$; $A$ ii, 251, 298, 308; $C$ i, 167168.
1306-1329

$+$

Many wars in which the country was exhausted, but victories far outnumbered the defeats. Scotland was consolidated and 
RULER

Minority of David II

(Randolph, Earl of Moray, Regent) $A$ ii, 310 .

\section{Minority of David II}

(Donald, Earl of Mar, nephew of King Robert Bruce, Regent)

Weak and incapable. $b ; A$ ii, $310 ; B$ i, 304; $C$ i, 171.

Minority of David II

(Sir Archibald Douglas, and afterwards Sir Andrew Moray, Regents)

$\mathrm{C}$ i, 174.

\section{$\pm \quad$ Minority of David II}

(Robert Stuart (afterwards Robert II)

Regent. At this time young and active

$b ; A$ ii, $369 ; B$ i, 313.

\section{- David II}

Incapable, headstrong, extravagant, passionate, and devoted to pleasure. $A$ ii, $337 ; B$ i, 308 , 310, 313; $C$ i, 175, 178.

\section{\pm Robert II (House of Stuart)}

A man of judgment and fair ability, but at that time of his life in poor health, indolent, and
Condition OF CoUntry

freed from English rule. Many wise laws were enacted relative to the administration of justice and organization of the army. $b$; $A$ ii, 244, 250, 263, 303, 305, 308 ; $B$ i, 295, 296, 300; $C$ i, 161, $163,166,169$.

Vigorous and successful government. $b ; B \mathrm{i}, 304$.

July, 1332-August, 1332

Disasters. $b ; \quad B \quad \mathrm{i}, 304,305$.

\section{2-1338}

Scots defeated by the English. $b ; B \mathrm{i}, 305-306$; $C \mathrm{i}, 172,174$.

\section{8-1341}

Strongholds of Perth, Sterling, and Edinburgh were won back. $C \mathrm{i}, 174,175$.

\section{2-1371}

Scots defeated. English overran the southern part of Scotland, which was obliged to pay a large ransom to England. Deplorable state of internal disorder. Turbulence among the nobles. Impoverishment of the country. Some parliamentary advance. $\quad b$; $A$ ii, 324, 325; $B$ i, 308-309; $C$ i, 180-183.

\section{1-1390}

Rather uneventful and vague conditions. Scots were victorious over the English at Otter- 
RULER

peace-loving. Simple and affable in his manners. Not much is known about his private life. Had many illegitimate children. $b$; $A$ ii, 369 ; $B$ i, 313 ; $C$ i, $186-$ 187.

\section{Robert III}

Of less intellect and even more indolent then Robert II, his father, otherwise much like him. $b ; A$ ii, $372 ; B$ i, $320 ; C$ i, $195-$ 196, 202.

\section{$+\quad$ Minority of James I}

(Robert, Duke of Albany, son of Robert II, Regent)

A man of energy and ability. $A$ ii, 39.5; $B$ i, 326; $C$ i, 203, 208.

\section{- Minority of James I}

(Murdock, son of Albany, Regent)

Weak, lazy, incompetent. $b$; $B$ i, 326 . $+$

James I

Fearless, active, accomplished. An able administrator and organizer. Literary tastes. A lover of peace and justice. $a$; $A$ ii, 409 ; $B$ i, 330, 335, 336; $C$ i, 216.

\section{- Minority of James II \\ (Regency divided)}

Archibald, and then William, Earls of Douglas, were only nominally regents. Crichton and Livingstone alternately had the custody of the young king.
Condition of Cotntry

bourne, 1388. "Social progress of the nation was much retarded." Minor Border raids, but the general result was a graclual recovery of Scottish territory. $b ; A$ ii, 348, 357, 365; $B \mathrm{i}, 313,317,319 ; \quad C \mathrm{i}, 188,194$.

\section{0-1402}

Decline. Scots suffered several defeats. English harried over the border. Lawlessness among the nobles, miseries among the people. Parliament enacted some good laws. $b ; A$ ii, $372-374$; $B \mathrm{i}, 320,322-323 ; C \mathrm{i}, 196,199$, 201.

1402-1420

Important victory for the government at Harlaw. Better establishment of order. A ii, 387$394 ; B$ i, 326 ; $C$ i, 205, 208.

\section{4}

Distinct decline. $C$ i, 209 .

\section{4-1437}

Prosperous and comparatively peaceful reign. Subjugation of the Highlands. Many legal reforms relative to private warfare, justice, commerce, coinage, etc. Many parliaments. $b ; A$ ii, 399-409; $B$ i, 327, 330, 332, 333, 337 ; $C$ i, 212, 214, 218.

\section{7-1451}

A period of private wars. b; $C \mathrm{i}, 223-229$. 


\section{Ruler}

${ }^{1}$ James II

Accidentally killed in his thirtieth year. Considered a promising young man, energetic and impulsive. $b ; C$ i, 231, 241, 242 ; $D$ i, 328, 333 .

\section{$+\quad$ Minority of James III}

(Kennedy, grandson of Robert III, Chief Regent)

Wise, moderate, and upright. $a ; b ; A$ iii, $2 ; B$ i, $345 ; C$ i, $256 ; D$ i, 338-339.

\section{Minority of James III}

(Regency divided)

\section{- James III}

Lacked bravery and energy. Of rather inferior capacity, though a lover of literature and the fine arts. Charged with a propeusity for low company. $a ; A$ iii, $19,24,33 ; B$ i, 348; $C$ i, $269,287-288$.

\section{$\pm \quad$ James IV}

Ambitious and brave, but rash and quixotic. Not adept in diplomacy or generalship. Truthful, liberal, and popular, but licentious. $a ; b$; $A$ iii, 51-80; $C$ i, 295, 307, 339 .

\section{Condition of Codntey}

\section{1-1460}

Civil wars and border raids. Good progress in legislation relating to agriculture, coinage, and the administration of justice. $b ; B \mathrm{i}, 340,341,343,344$; $C \mathrm{i}$, 242-245.

\section{$1460-1466$
Comparatively peaceful and} orderly. Lord of the Isles defeated. $b ; A$ iii, $2 ; B$ i, 345 ; $C$ i, 256, 257; $D$ i, 338 .

\section{6-1474}

Plots and conspiracies among the nobles. Decline in the administration of justice. $b ; A$ iii, $9 ; B$ i, 345-346, 347; $C$ i, 257.

\section{4-1488}

A period of lawlessness. Conspiracies of the malcontents. Defeat and murder of the king. Loss of Berwick to the English. Debasement of the coinage. $b$; $A$ iii, $18,23,27,29 ; B$ i, 34, 350 , 351,$352 ; C$ i $285-287,288,290$, $291,293$.

\section{8-1513} $\pm$

Establishment of law and order. Beginnings of naval power. Increase in international importance and commerce. Disastrous defeat at Flodden, in which the flower of Scottish chivalry perished. Financial exhaustion. $A$ iii, 45,55 , 56,$79 ; B$ i, 357, 359, $363 ; C$ i, $294,298-300,310,313,337-340$, 345. 
RELER

$\pm \quad$ Minority of James V

(John Stewart, Duke of Albany, cousin to James V, Regent part of the time)

Difficult to estimate. One finds differing views about him. Enterprising and able as a negotiator, though a poor general. Lavish and extravagant. $a ; B$ ii, 36 ; $C$ i, 355 .

\section{- Minority of James V (Regency divided part of the time)}

$+\quad$ James V

Ambitious, vigorous, with more than average ability. Popular with the lower classes. Irregular in his manner of life. $a ; b: A$ iii, $184 ; B$ ii, 62 ; $C$ i, 374,396 .

Minority of Mary

(James Hamilton, Earl of Arran, Regent)

Weak, easy, fickle. $C$ ii, 4 .

$+\quad$ Minority of Mary (Mary of Lorraine, Regent)

A strong, able character. $B$ ii, 87 ; $C$ ii, 40,69 .

\section{+ or \pm Mary, Queen of Scots}

Brilliant and emotional. Not particularly wise politically. Passionate, revengeful, and unpatriotic. $a ; b ; A$ iii, $137 ; C$ ii, 101, 116.

\section{Condition of Country}

1513-

Turmoil and internal contest. Merges into the following period. $A$ iii, $89,93,95 ; B$ ii, 36, 37 ; $C$ i, 358-363, 366-367.

$-1528$

Unsettled conditions continued. $A$ iii, $89,93,95 ; B$ ii, 36 , 37 .

\section{8-1542}

Successful reign with the exception of the Srotch defeat at Solway. Renewed orler and prosperity. $b ; A$ iii, $183 ; C$ i, 392 , 394, 396, 397, 399 .

\section{$1542-1554$}

The country suffered greatly by the English raids. $b ; A$ iii, 233,241 , 269 ; $B$ ii, 66, 76, 86; C ii, 10-11, 13, $15-16,19,23,30-31,33-36$.

\section{$1554-1560$}

$\pm$

Events of the Reformation. No marked progress or decline in political or material matters. $b$; $A$ iii, 303, 309, 367, 369, 373; $B$ ii, $90-100$; $C$ ii, $39-44,45-78$.

$$
\text { 1560-1567 - or } \pm
$$

Condition similar to the foregoing period. $A$ iii, 31, 49, 56, $65,69,89,114,123,127,129,233$, 235,247 ; $B$ ii, $118,120,125,143$, $144 ; C$ ii, 81, 117-118. 
ROLER

$+\quad$ Minority of James VI (Murray, Regent)

A man of energy and firmness. His character has been estimated very differently according to the temper or prejudice of those who have judged him. $a ; B$ ii, 152 ; $C$ ii, 143.

\section{$\pm \quad$ Minority of James VI \\ (Matthew Stuart, Earl of Lenox, Regent)}

"Intellectual medocrity and lack of personal stamina." $C$ ii, 145 .

$\pm \quad$ Minority of James VI

(Earl of Mar, Regent)

Not distinguished. "Honest and faithful.", $\quad$ ii, 151.

\section{- Minority of James VI \\ (Earl of Morton, regent)}

Non-royal. $a ; b ; A \mathrm{v}, 133$; $B$ ii, 155 ; $C$ ii, 160-161, 164, 181.

\section{- Minority of James VI (Regency divided)}

\section{$\pm \quad$ James VI (I of England)}

Shrewd, but vain, foolish, and weak. Learned, but pedantic and trivial. Pompous and arbitrary. Not the coward he is sometimes painted. $a ; b ; B$ ii, 187, 219; $C$ ii, $274,275,280$.

\section{Condition of Country}

\section{7-1570}

Order restored and justice administered. Then famine and pestilence. English invasion and eivil war, 1569. $b ; A$ iv, 290 , $365, \mathrm{v}, 7,9,23,29$; $B$ ii, 149,150 ; $C$ ii, 134, 141-142.

\section{0-1571}

Plots and counter plots. Intrigues and seizures. $B$ ii, 152 ; $C$ ii, 147 .

\section{1-1572 \\ Civil wars and turmoil. $b$;} $A$ v, 67 ; $C$ ii, 151, 156.

\section{2-1580}

Peace and order reëstablished. $A$ v, $133 ; B$ ii, $165 ; C$ ii, 162 , 164-165.

1580-1587
Disorder. Raid of Ruthven.
$b ; A$ v, $189 ; B$ ii, 179, 182, 183.

\section{7-1625}

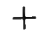

Diminution of disorder. Some inerease in general prosperity. Introduction of new industries, glass, soap, and leather, and development of woolen manufacture. Loss of politieal liberty. $b$; $A$ v, 317 , vi, 17,18 ; $B$ iii, 2 ; $C$ ii, $167,276-278,280-281,283$. 


\section{BIBLHOGRAPHY FOR ENGLAND}

a. Dirtionary of National Biography. 66 vols. London, 1885-1901.

b. Encyclopædia Britannica. 9th and 11 th editions.

A. Green, J. R. A Short History of the English People. 4 vols. London, 1s94. New York, $1 \$ 93$.

B. Freemax, E. A. The History of the Norman Conquest. 6 vols. Oxford, $1 \leq 71$.

C. Stubis, Willian. The Early Plantagenets. New York [1876]. [Eporhs of Modern History.]

D. Gardiner, S. R. The History of Eingland from the Accession of James 1. 10 vols. Lonton, 1893-99.

E. Rogers, J. E. Tnoroun. The History of Agriculture and Prices in England. 7 vols. Oxford, 1866-1902.

F. Coxwarim, W. The Growth of English Industry and Commoree during the Early and Middle Ages. Cambridge, 1890.

(i. (Ineycer, E. P. Introduction to the Industrial and Social History of England. New York, 1901.

H. Traill, II. D. (Editor). Social England, A Record of the Progress of the People, by Nineteen Specialists. 6 vols. London, $1893-97$.

J. STrubs, IT. The Constitutional History of England, in its Origin and Development. 3 vols. Oxford, 1874-78.

K. Fresuan, F. A. The Reign of William Rufus and the Accession of 11 enry 1. 2 vols. Oxpord, 1 sti2.

L. Cibbixs, II. de B. Commeree in Europe. London, $1 S 91$.

M. Yeates, J. The (irowth and Vicissitudes of commerce. London, 1872 .

N. Woodward, W. II. Expansion of the British Empirc. Camlirilge, 1 s 99.

O. The ('ambridge Modern Ilistory. Edited by (A. W. Ward, G. W. Prothero, Stanley Leathes, planned by the late Lord Acton). 13 rols. Cambridge, England, 1902-11.

P. RAnsay, SIR J. II. The Angevin Empire. London, 1903.

Q. Wrute, J. It. History of England under Ifenry IV. 4 vols. London, 1sSt-9s.

R. RAMsAY, Sir J. H. The Foundations of England. 2 vols. London, 1898 .

S. Hunt, IV., Poole, R. L. (Editors). The Political History of England. 12 vols. London. 1907.

T. Norgate, Kate. England under Angevin Kings. 2 vols. London, $18 s 7$.

$U$. DAris, H. W. C. England under the Normans and Angevins. London, 1905. 
RULer

\section{$+\quad$ William I (the Conqueror)}

Remarkable genius and iron will. An unscrupulous and somewhat eruel tyrant. Good husband and father. $a ; b ; A$ 165; $B$ iv, $18,612,615 ; S$ ii, 9-10.

+ or \pm William II (Rufus)

Brave and able soldier, crafty statesman. Clever but unsustained. A violent ruffian, extremely tyrannical and perfidious, espeeially debased in his private life. Both avaricious and extravagant. $a ; b ; A 166 ; K \mathrm{i}, 5$, 144-59, 168-71; ii, 335, 337, 490-504; $S$ ii, 80 .

\section{$\pm \quad$ Henry I (Beauclerc)}

Of marked ability and selfcontrol. A good soldicr and a great administrator. Energetic, industrious, learned, eloquent, and judicious. Cold, erafty, eruel, and dissembling. Temperate; he was, however, licentious. $a ; b$; $K$ i, 197, ii, 379-82; $R$ ii, 319$322 ; S$ ii, $115-7$.

\section{- $\quad$ Stephen}

Brave, active, and well-meaning, but incapable. "A mild man, soft and good, and did no justice." Frank and generous. $a$; $b$; A 193-197; $R$ ii, 345, 453-4, $S$ ii, 196, 204, 207, 214, 227 .
Condition of Country

1066-1087

England unified. Marked advance in law and order, although the people were oppressed. $a$; $b ; B$ iv, $18,612,615 ; G 14,17$; $S$ ii, $10-11$.

$\begin{array}{cr}\mathbf{1 0 8 7 - 1 1 0 0} & \pm \\ \text { Conquests in Normandy and }\end{array}$ Main. Extension of the power of England on the Welsh marches. Settlement of northwestern frontier. But the heavy cost of the wars brought the people to a sta to of extreme wretchedness. Taxation was especially oppressive. $b$; A 166; $K$ i, 4-5, 153, 474, ii, 337 ; $S$ ii, $73,91$.

\section{$1100-1135$} $+$

The taxes were heavy, but the general picture of this reign is distinctly bright. Peace and security in the land, and relatively active trade. The country gained in prestige through the French wars. Charter of Liberties. Many towns also received charters. $a$; $b ; A 183 ; B 152 ; F 133 ; K$ ii, 402, 454-5; $S$ ii, 156, 168, 189-90.

\section{5-1154}

A period of anarchy and suffering. Invasion by the Scots and loss of territory on the Border. $a ; b ; A 193 ; G 19 ; R$ ii, 345 ; $S$ ii, 196, 214, 253. 
RULER

$+$

Henry II

Rough, sensuous, vigorous, industrious, and learned. Temper violent. A great lawgiver. Led an extremely active life. Had a wonderful memory. His worst eharacteristie was his tricky dishonesty. He was certainly popular with al classes of the people. a; A 197-9; $P$ 246-8; $S$ ii, $255-8$.

\section{+ or $\pm \quad$ Richard I}

Brave and brilliant warrior. Possessed many aecomplishnents. Frank, generous, and sincere. He was also passionate, impetuous, licentious, and haughty, but not essentially cruel. a: $A 213$, 214; $P$ 367; $S$ ii, 335, 361-3; $T$ ii, 207-8, 281, 320 .

$+$ John

Not lacking in rleverness and spasmodir energy, but devoid of judgment and breadth of insight. Utterly depraved, mean, vindictive, licentious, ruel, and false. a; $A$ 231; $P 379 ; 502-3 ; S$ ii, 401-3.

\section{- Regency}

William Marshall, Earl of Pembroke

\footnotetext{
- $\quad$ Regency (Divided)

Hubert de Burgh, Pandulf, Peter de Roches, Stephen Langton.
}

\section{Condition of CodNTRY}

\section{4-1189}

Reëstablishment of law and order. Marked advance in jurisprudence. Reforms in the eurreney. England's power rose. Aetive building. a; $b ; A$ 198, $199,210,211 ; P 248-57 ; S$ ii, $256-7,320-6,352$.

Constitutional progress along the lines of the former reign. The eountry suffered from exeessive taxation resulting from the erusades and the king's ransom. b; A 215; G 25; P 272, 351. 


\section{RULER}

\section{Henry III}

Feeble administrator. Vain, reckless, extravagant, obstinate, and undependable. Sexually moral and not in the least cruel. $a ; b$; A 271, 272.

\section{Condition of Country}

\section{7-1272}

A period of trouble and suffering. In contrast we find the beginnings of a parliament and germs of constitutionalism. The crown became impoverished, but the wealth of the nation was as a whole increased. There was much building on a large scale. b; $A$ 279, 292, 293, 300; C 161 .

$+$ Edward I

Stern, able, laborious, and conscientious. Practieal administrator. Chaste and temperate. True to his word. Arrogant, vindietive, and perhaps cruel. $a$; A 324, 345, 347, 350-351 ; F 242-245, 247.

\section{Edward II}

Cowardly, incapable, dissolute. A hard drinker. Not tyrannical. Weak, indolent, and faithless. $a ; b$.

\section{- Regency (Divided) \\ Queen Isabella, Mortimer, and several others.}

\section{$+$}

\section{Edward III}

Extremely enterprising and adventurous. Brave, active, and able, though not a great organizer. Selfish, ambitious, ostentations, and licentious. $a ; b ; J$ ii, 374 .

\section{2-1307}

General prosperity and marked economic advance. Judicial reforms. Conquest of Wales and Seotland. Depletion of treasury. $a ; b ; A 322,324,331 ; F 241$.

$\begin{array}{rlr} & \mathbf{1 3 0 7 - 1 3 2 7} & - \\ \text { Misery } & \text { and national decline. } \\ \text { Loss of } & \text { Seotland. } a ; & b ; \quad A \\ 408-409 ; & J \text { ii, } 323 .\end{array}$

\section{7-1330}

War with Scotland unsuceessful, and "Shameful Peace". of 1328.

\section{0-1377 +}

Restoration of order. Important constitutional and social advance. Extension of international importance and growth of eommerce. However, a reign of hardships and poverty for the people. Black Death. $a ; b ; A 440,444,448,478,495$; $F 245 ; J$ ii, $311,373,375,377$, 380 . 
RCLER

Regency (in a Council)
Condition of Country

1377-1389

Political and social discontent. Peasant risings, under Wat Tyler, and others. War with France, characterized for the most part by disasters. $b ; A 485-497$.

$$
\text { 1389-1399 - or } \pm
$$

Court factions and petty civil warfare. Misery and discontent continued. Power of House of Commons increased. $b ; A 485$, $505-508$; $J$ ii, 303, 305, 463, 513, $622 ; Q$ i, 2.

1399-1413

The general poverty of the previous reign continued. Internal troubles and rivil wars. The nation gained ground in political power and prestige. Increased influence of the Commons. $b$; $A$ 514-516; $J$ iii, 2, 45,$70 ; Q$ i, $404,437,449$, iii, 300 , iv, 144 , 145-150.

\section{$+\quad$ Henry V}

Brilliant commander and statesman. Pure in life, temperate, liberal, merciful, and honourable. $a ; b ; c ; J$ iii, 75; 5 iv, 230, 232, 285 .

\section{- Regency \\ Humphrey of Gloucester}

Fourth son of Henry IV, held the title of Protector, but the real government was equally shared by the Council. The

\begin{abstract}
1413-1422
Conquests in French territory. England's glory greatly enhanced and diplomatic position strong. Internal order was maintained, but the country was much drained on account of the French war. $b$; $F$ i, $369 ; J$ iii, 93 ; $S$ iv, 236-238,
\end{abstract} 281.

\section{2-1440}

Loss of French territory. Decline in England's political prestige. "The general state of things had never been less hopeful.". Parliamentary franchise 
RULER

Duke of Bedford, third son of Henry IV, also played an important role as leader in France, and as regent.

\section{Henry VI}

Extremely weak, with periods of insanity. $\mathrm{He}$ was mereiful, pious, domestic. Had literary tastes.

\section{\pm or $+\quad$ Edward IV}

Brave, vigorous, eloquent. Vicious, eruel, sensuous, and extravagant. An able general and diplomat, but was spasmodic in his activities. Affable in his manners and popular, in spite of his vices and autoeratic rule. $S$ iv, 411, 412, 419, 450, 451, 469.

\section{\pm or $+\quad$ Richard III (Regent and King)}

Brave, ambitious, cunning, and clear-sighted. Probably cruel and unserupulous, though not the monster eommonly pietured. There is singularly little known about Richard III. $a ; b ; J$ iii, 225; Gairdner's " Richard III ; " Markham's "Richard III."

\section{$+\quad$ Henry VII}

Prudent, vigorous, able, despotic, and very avaricious. A patron of art, literature, and

\section{Condition of Codntry}

became narrowed by statute of 1429. $b$; A 527-544; $J$ iii, 118 ; $S$ iv, 286-300.

\section{0-1461}

(1440. End of Gloucester's Regency.)

(1442. Majority of Henry VI.)

Further loss of French territory. Country impoverished and exhausted. Anarehy prevailed. Cade's rebellion. $a ; b ; A$ 545554 ; $J$ iii, $143,144,150 ; S$ iv, 310-404.

1461-1483 \pm

Civil and agricultural wars and violence. Commercial advanee and the beginnings of manufacture. Mueh building of churches and manor houses. The Wars of the Roses did not much affect the general prosperity. Legislation and taxation were poorly administered. Power of Parliament deelined. $b ; A 561$; $J$ iii, 209, 217, 273, 275, 286.

\section{3-1485}

Similar to the reign of Edward IV. $b ; A 561,584-587 ; J$ iii, 235.

\section{5-1509}

Gradual establishment of order. Marked growth of commerce. Constitutional retrogression be- 


\section{RUler}

eommerce. His chief fault was his praetice of extortion. Details of his private life but little known. $a ; b ; c ; A 592$.

\section{$+\quad$ Henry VIII}

Extraordinary vigour of mind and inflexibility of will. Aceomplished and versatile, but imperious, selfish, eruel, and sensual. $a ; c ; O \mathrm{ii,} 462$.

\section{- Regency for Edward VI Somerset and Northumberland Protectors}

\section{$\pm \quad$ Mary}

High-spirited and courageous, and devoted to what she considered her duty. In her youth precocious and promising, but afterwards suffered from a weak constitution. In her latter days mentally unbalanced. Not wantonly eruel. $a ; b ; c ; A 720$.

\section{$+\quad$ Elizabeth}

Extremely able, scheming, practical, and hrave. Vain, luxurious, wilful, mendacious, and vindictive. Patriotic and unusually popular. $a ; b ; c ; 1733-745$.
Condition of Cocntry

gan during the latter part of the reign, with decline of the power of the baronage. Exchequer well filled. Navy strengthened. $b$; c; A 563-565; L 97 .

\section{9-1547}

$+$

Greatly increased importanee of England internationally. Growth of agrieulture, grazing, commerce, manufaetures and navy. Greater influence over Wales and Ireland. Constitutional decline. $b ; M 260 ; O$ ii, 462.

\section{7-1553}

Deeline in international prestige. Depletion of the treasury. Rerolts and general discontent. $b ; A 712,715,716 ; O$ ii, 477, 496.

\section{3-1558}

A period of persecution. England defeated and humiliated abroad. $b ; A 731,732$.

\footnotetext{
1558-1603

Peace, prosperity, progress. Political prestige vastly increased. Growth in wool manufactures, but greater growth in eommerce. $b$; A 744, 745, 778, 780, 785, 789.
} 
RULER

$\pm$

James I

Shrewd, but vain, pedantie, and trivial. Unscrupulous, pompous, and arbitrary. A heavy drinker. $a ; b ; c ; A 974$.

$\pm$

Charles I

Proud, reserved, aecomplished. Little political wisdom. Temperate and chaste. His chief faults were duplicity and obstinacy. $a ; b ; A 1019 ; H$ iv, 159 .
Condition of Coontry

1603-1625

Steady progress in material conditions. Improvement of agrieulture. Colonial expansion. Growth of manufactures. European eampaigns and policies not suecessful. Foreign political prestige deelined. $b$; A 990, 1002 ; $H$ iv, 46, 4S, 122 , $124,130,133,141,143,15 S, 439$.

1625-1649
Expansion of commerce and
general material prosperity. De-
cline in international prestige.
Publie diseontent. Distress dur-
ing civil war. Parliament strug-
gled for its existence. $A 1027$,
$1033,1070,1072,1075,1112$,
$1117 ; E \mathrm{v}, 68 ; H \mathrm{iv}, 48$.

1649-1659

$+$

Marked improvement in commerce, agriculture, and in the navy. Order established. $b ; A$ 1222,$1260 ; \quad I I$ iv, $440 ; N 127$.

\section{Charles II}

Affable, witty, and debonair, but had no ambition. Sensual, dissipated, indolent, and extravagant. $a ; b ; c ; A$ 1351-1356.

\section{James II}

Industrious and perhaps wellmeaning in his political aims, but lacked judgment, tact, and $2 \mathrm{D}$

\section{0-1685}

Important constitutional and legal advance. Growth of the House of Commons. Increase in shipping, silk trade, and banking. Agriculture did not improve. Much desirable immigration in iv, $350,362,363,450,454,455$.

\section{5-1689}

Further development of industries. Tyramy. People and Parliament finally asserted themthis and subsequent reign. Foreign poliey weak. A $1435 ; H$ 
Reler

breadth of insight. Much courage and fair ability in youth, but this had deteriorated by the time of his accession. A great libertine until a $\mathrm{few}$ years before his death, when he beeame a religious ascetic. $a ; b ; H \mathrm{iv}, 351$.

\section{$+\quad$ William III}

Extraordinarily precocious. One of the greatest of diplomats. Able as a statesman. As a soldier, brilliant, though less great. Brave, active, resourceful. Not popular. "An outward coldness covered a hidden warmth." Both arbitrary and magnanimous. His aims were noble, his honour unreproached. Free from vanity. Domestic life not praiseworthy. $a ; b$. See also under Netherlands.

- $\quad$ Anne

Dull, narrow, weak, obstinate. Deeply religious. Many simple virtues. $a ; b$.
Condition of Country

selves, 1685. Henceforth House of Commons most important branch. $b$; A 1481-1483; $H$ iv, $349,352,375$.

\section{9-1702 \\ Development of a constitu- tional monarchy. Bill of rights. International prestige again as in the days of Cromwell. Trade and wealth inereased. $b$; $A$ 1526,1529 ; $H$ iv, 451, 507, 508, $513,585,592$.}

\section{2-1714}

$\pm$

Successful forcign poliey. Conmerce continued to expand. Industries prospered. New trade established with Nova Scotia, Newfoundland, and Hudson's Bay territory. Gibraltar and Minorea acquired. Growth of the Cabinet. $b ; A 1570 ; H$ iv, 516,518 , $581,585,587$.

\section{- George I}

Dull and ignorant except for a fair knowledge of military affairs, frugal, steadfast in his friendships. Coarse in his tastes. Vicious in his private life. $a$; $b ; c ; A 1579$.

An era of peace and material progress. Silk, woollen, linen, and glass industries prospcrous. $b$; A $1592 ; H \mathrm{v}, 1,2,111,117$. 
Ruler

George II

Dull, methodical, parsimonious, a martinet. Coarse and licentious in his tastes. $a ; b ; c$.

\section{$\pm \quad$ George III}

Had a good memory. Much tenacity of purpose and talent of a narrow sort. Unyielding, frugal, of punctilious virtue. Last part of his life he was insane. $a ; b$; $c$; A 1665-1667; Also Beckles Willson, "George 111, as Man, Monarch and Statesmau," (1907).
Condition of Codntry

1727-1760

1727-1739, Peace and prosperity. 1739-1760, Foreign policy became more vigorous. Victorious in foreign wars. Conquest of Canada and India. Foundation of charitable institutions. $b ; A$ 1594-1596, 1619, 1648, 1657-1661; $H \mathrm{v}, 6,185$.

1760-1811

$+$

Loss of the American Colonies, but commerce with them was soon greater than before. Great progress in agriculture, with the seience of eultivation and rotation of erops, and in cattle through improvement in breeds. In manufactures by inventions like the flying-shuttle, jenny, mule, and steam-engine. Many canals built and water lands reclaimed. $b ; A 1620,1718,1727$, $1729 ; \quad H \mathrm{v}, 301,305,367,369$, $452,482,499,568$. 


\section{APPENDIX II}

[Reprinted from Science, N.S., Vol. XXX., No. 777, pp. 703-704, November 19, 1909.]

\section{A NEW NAME FOR A NEW SCIENCE ${ }^{1}$}

The following list, though noticeably brief, attempts to include all books and memoirs in which the facts of history of a personal nature have been subjected to statistical analysis by some more or less objective method. Such researches may be made to contribute to the science of eugenics. They also stand upon the border line of the allied sciences, psyehology, anthropology, and sociology. Since investigations of this nature contribute to several seiences, and at the same time primarily to the philosophy of history itself, it seems necessary to have some special name to designate this class of work. The word "biometry,", already in general use, does not meet the requirements. It fails to express the primary value of this elass of research, namely, elucidation of the philosophy of history for its own sake, and also fails to suggest that the work should be carried forward by the historians themselves. I propose the word "historiometry,". derived from the Greek iaropia, history, and $\mu t \tau \rho o \nu$, measure.

It may be noticed that these investigations treat only of groups of individuals. I am already convinced from the indications of several researches which I have now under way, that the quantitative method may be successfully applied to historical events of a more general character.

\section{BIBLIOGRAPHY OF HISTORIOMETRY}

De Candolle (Alphonse). " Histoire des sciences et les savants depuis deux sièoles." Genève, etc. (H. Georg), 187̈3. Contains lists of scientific names objectively (impersonally) compiled.

Cattell (J. MeKeen). "A Statistical Study of Eminent Men." Popular Science Monthly, February, 1903, pp. 359-377. [Abstract in Psychological Reriew, March, 1895.] The names of a thousand emi-

1 "Some Desiderata in the Science of Eugenics and Bibliography of Historiometry," by Dr. Frederick Adams Woods. Reprinted from Vol. V. of the American Breeders' Association Report of the Meeting, held at Columbia, Mo., January 6, 7, and 8, 1909. Report of the Committee on Eugenics. 
nent men of all time are here arranged in the order of their eminence by the strictly objective, and valuable "space method." Attempt should be made to test the limits of the accuracy of this method by comparing these names with those selected by other methods.

Cattell (J. McKeen). "A Statistical Study of American Men of Science." Science, November 23, November 30, December 7, 1906. Although the facts are not drawn from history, they are useful as a check to compare with historical statistics. The names were selected by the "method of voting."

Ellis (Havelock). "A Study of British Genius." London (Hurst \& Blackett), 1904. [First appeared in Popular Science Monthly, February-September, 1901.] A valuable study based upon the "Dictionary of National Biography." Contains lists of British men of genius and talent, objectively derived and useful for further study. Galton (Francis). "Hereditary Genius. An Inquiry into its Laws and Consequences." 2d edition. London (Macmillan), 1892. The earliest of biographical statistical studies, first published in 1869. Many of the lists of names are not compiled by any strictly objective method.

Galton (Francis). "English Men of Science, Their Nature and Nurture." London (Macmillan), 1874. Fellows of the Royal Society. Galton (Francis) and Schuster (E.). "Noteworthy Families." London (Murray), 1906. Families of scientific men objectively studied. Jacoby (Paul). " "Études sur la sélection ehez l'homme." Avant propos par Gabriel Tarde. 2d edition. Paris (Alcan), 1904. The last quarter of this work dealing with the origin of French men of talent has decided scientific value. The first portion of the book deals with royalty, le pouvoir, contains no statistical treatment, and is entirely misleading.

Lorenz (Ottokar). "Lehrbuch der gesammten wissenschaftlichen Genealogie." Stammbaum und Ahnentafel in ihrer geschichtlichen, sociologisehen und naturwissenschaftlichen Bedeutung. Berlin (Hertz), 1898. Suggestive at the time it was written, but contains searcely any statistical treatment.

Odin (A.). "Genèse des grands hommes gens de lettres français modernes." 2 vols. Paris (H. Welter), 1895. A study of 6382 French men of letters. Valuable for its facts. The conclusions are often unwarranted.

Woods (Frederick Adams). "Mental and Moral Heredity in Royalty : a Statistical Study in History and Psychology, with 104 Portraits." New York (H. Holt), 1906. [Abstract in Popular Science Monthly, August, 1902-April, 1903. Brief abstract in Psychological Review, March, 1902.] The individuals are included in the study by a 
strictly objective plan. Attempt is made to reduce the subjective element to a minimum while grading them to a scale of ten, by averaging opinions of historians. Conclusion that heredity outweighs environment is arrived at by several statistiral methods. The general method of "averaging opinions" is shown to be practical and to give orderty results, harmonious with other researches in heredity. Human heredity shown to be "alternative" (non-blending).

"The Great Mo'n of France (XIXth Century)." From London Times in Science, January 11, 1907. Names were obtained by popular vote.

Frederick Adams Woods.

Massachusetts Institute of Technology. 


\section{APPENDIX III}

[Reprinted from Sciencc, N.S., Vol. XXXIII., No. 850, pp. 568-574, April, 14, 1911.]

\section{HISTORIOMETRY AS AN EXACT SCIENCE}

In the issue of Science for November 19, 1909, under the title "A New Name for a New Science" I proposed the term historiometry for that class of rescarches in which the facts of history have been subjected to statistical trcatment according to some method of measurement more or less objective or impersonal in its nature. These researches have chicfly had in view the listing and grading of historical characters, either for the purpose of studying mental heredity or for the better appreciation of problems associated with the psychology of genius. Researches of this type are capable of a far greater expansion and applieation than is generally supposed. They ean be applied to events as well as to individuals. They can, by treating the vast store of human records which exist in books as material for the construction of an exact seience, work towards the solution of a wide range of historical problems, such as the causes underlying the rise and fall of nations or other fundamental questions in history.

Before anything cau be lone which shall give general satisfaction and agreement it will be necessary for this subdivision of science to justify itself, to measure its own shortcomings, to appreciate its own limitations, as well as to prove its own right to reeognition of independent estate.

If we are to fathom historical causation by objective methods it is obligatory first to prove that history itself, as we commonly find it in the printed records, is a sufficiently valid account of what actually happened. Second, it is equally necessary to find proof that the objective nethods correctly deal with these facts. It might be supposed that the second proof awaits the first; but this is not neecssarily so. If the records themselves were very much at fault, so that the statements of historians were very far from ideal truth, or if the objective methods of eollecting and analyzing these statements were subject to a large error (or if both these forces were in play) then it would be difficult to find wherein the trouble lay. But if, on the contrary, it fortunately 
be that history as we find it is in its important statements a fair representation of the truth, and if the methods of historiometry which deal with these records are also sound, then it is not difficult to prove both propositions at the same time.

I will give some instances to illustrate this, which show that such is the ease for several types of historical records and for several methods of history measurement. This could not be done did we not possess some third criterion, some third standard of comparison of a non-historieal nature. One such non-historical criterion is furnished by the known correlation ratios for resemblances between elose blood relatives as determined in the anthropometric laboratory. These have been worked out and accurately neasured for mental and moral traits, stature, head index, and length of forearm. I have shown in "Heredity in Royalty" "that if the members of royal families are graded by the adjectives applied to them by historians and encyclopædists and then the eoefficients of resemblance are measured between the near of kin, who have been so graded, these coefficients (historiometric) substantially agree with the anthropometric. Such would not be the case if historians perverted the truth greatly, or if for any other reason the truth were largely unattainable. To make this clear it is only necessary to think what the result would be if history were merely "a pack of lies agreed upon" as the extreme view puts it. We should then fail to properly pick out our true intellectual giants and runts. The result would be nothing but confusion. A whole series of errors would bo distributed at random. This would art like rain on waves and flatten down to a common level the real differences between the individuals. The correlation measurements would fall and we should get no results comparable to those obtained from the delicate and accurate measurements of the anthropometric laboratory.

Furthermore, any weakness in the method of grading, any failure to properly elassify the great men in the high grades and the degenerates in their proper grades would work in precisely the same direction to lower the correlation coefficients. The supposed errors of history and the difficulties of grading act as two united strains of tension to pull the coefficients down towards zero, which would be the coefficient for random distribution. If the coefficient ean stand the strain without declining, then, roughly speaking, we may conclude both that the historical foundation is just and that the method of procedure is sound.

There are two other illustrations of method which I would like to summarize here. One of these series of tests is the trying out of a standard biographical dictionary (historical persons) against two lists of contemporaries (non-historical persons) and all three in terms of

$$
1 \text { New York, Henry Holt, } 1906 .
$$


still another set of facts, namely birthplaces of distinguished Americans. The second series of tests concerns the relative fame of Euripides versus Sophocles, the encyclopædias having been used and then this compared with expert modern criticism and both with the opinions of the Athenians.

As concerns American history, one fact is very evident at the start, whatever be the method of grading as applied to Americans or whatever be the mental eminence graded, some states in the Union, some sections of the country, have produced more eminence than others far beyond the expectation from their respective white populations. In this regard Massachusetts always leads, and Connecticut is always second, and certain southern states are always behind, and fail to render their expected quota. I have already pointed out ${ }^{1}$ that the ratios seem orderly for a first approximation. That is, the higher the grade of the individuals the greater and greater becomes the proportion of those born in Massachusetts. This may be expressed as a ratio, $\rho$ inte the random expectation. Thus if there were no forces at work beyond chance distribution the ratios for all sections of the country would be expressed by unity, $\rho=1$. If there be found twice as many persons born in a certain locality as one would expect from the population let it be expressed as $\rho=2$, three times as many, $\rho=3$, etc. These ratios are easily computed and can be expressed as fractions or with decimals. I have computed these ratios for the thirteen original states, but will present here only the statisties from Massachusetts and Virginia.

It will be seen in Table I, that Massachusetts has never failed to produce twice as many eminent men as the population would lead one to expect, and has for some ranks and types of achievement produced about four times the expectation. $\rho$ ranges between 2.1 and 4.7. Virginia, on the contrary, has but rarely produced as many as might be expected from the large white population, and the ratios in the same table are either below the expectation or not significantly above it. The other New England states (statisties not here given) have all done more than their share, but always less than Massachusetts. New York gives a trivial though constant excess above the expectation. From here southward the ratios drop off suddenly, so that Now Jersey, Delaware, Pennsylvania, Maryland, North Carolina, and Geergia have always furnished less than their share. For South Carolina the ratios again rise and exceed the expectation, but only by the slightest measurable amount. North Carolina, of all the thirteen original states, has always had the worst record in the way of producing distinguished

1"American Men of Science and the Question of Heredity," Science, N. S., Vol. XXX., No. 763, pp. 205-210, October 13, 1909. 


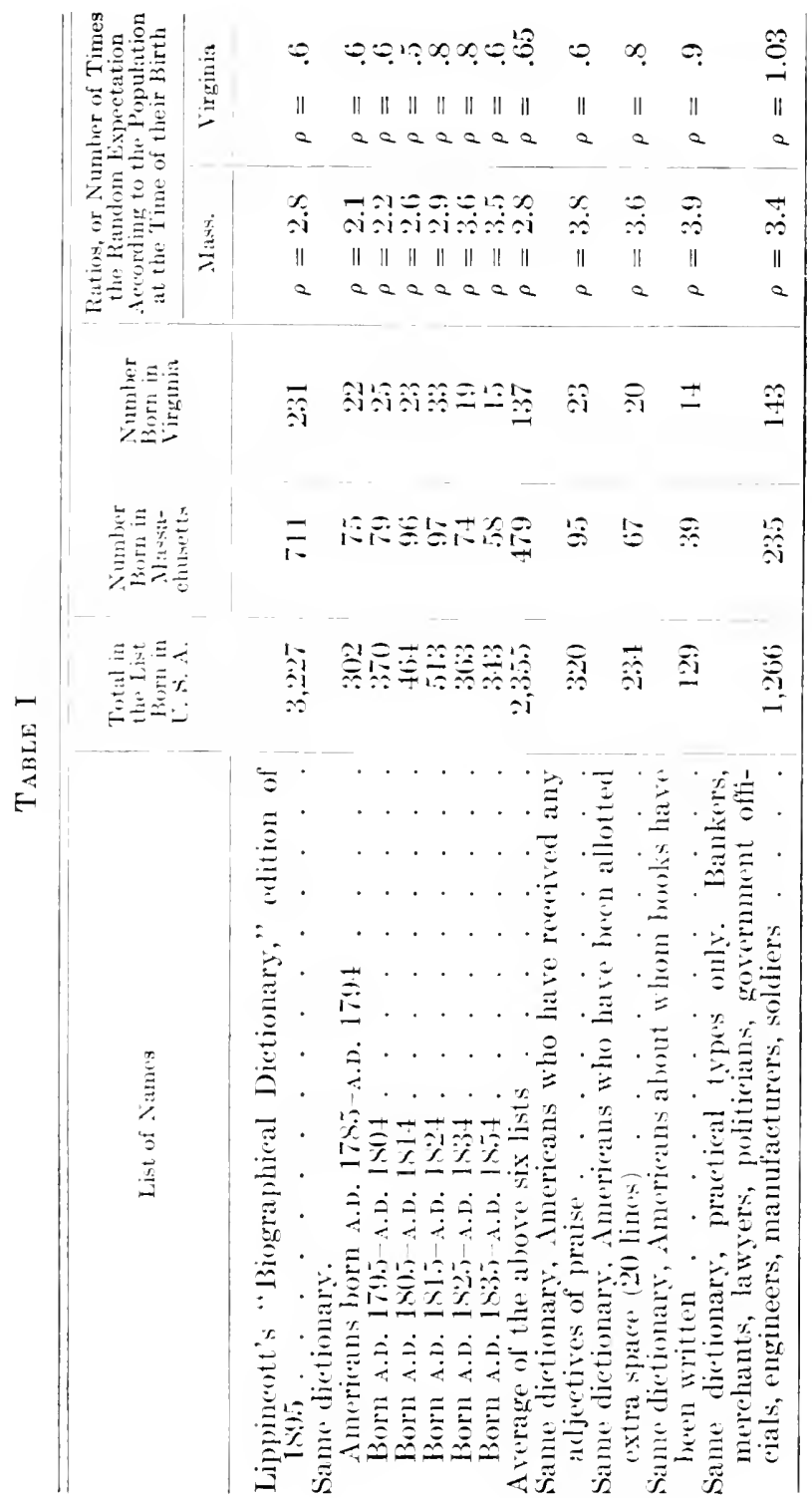




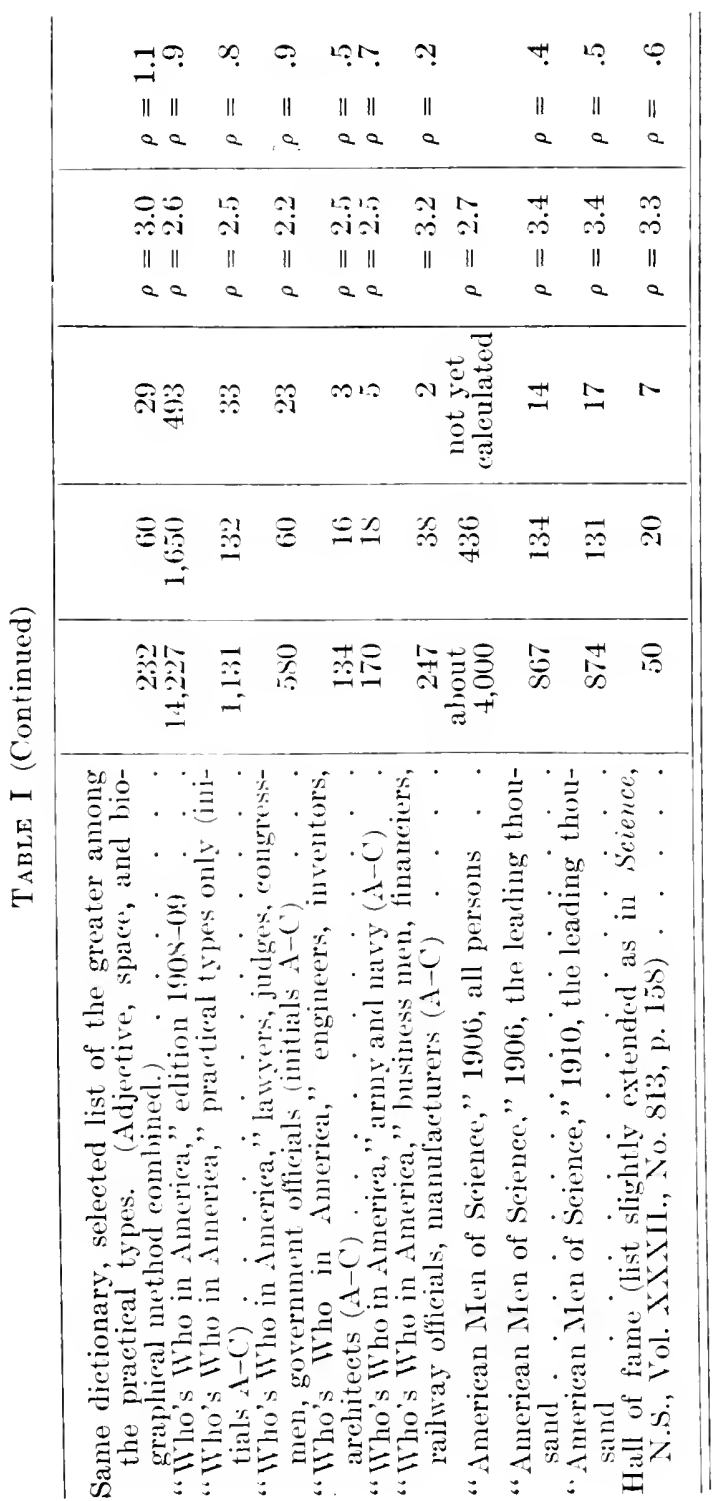


men; the ratios falling to about one quarter of what might be expected from the white population.

Regarding the tables for the two contrasted states, Massachusetts and Virginia, and following down through the columns marked "ratios, or number of times the random expectation according to the population at the approximate age of their birtl,," one sees first that the Massachuset ts ratios run from 2.1 to 3.9 and the Virginia from 0.2 to 1.1. The higher Massarlhusetts ratios are associated with the lists of names in which the standards for admission to the lists are higher - that is, specially sclected groups of the more eminent. Massachusetts also shows an extrit merit when seience or literature is alone considered, but this is merdy an arecentuation of some cause or causes which have enabled her to leacl. no matter what type of success be the criterion.

There is also to he seen a probably significant gain in the ratios for Mitsarehusetts from the ensus of 1790 to 18.50 . A further study of this special phenomenon might develop some interesting conclusions. The ratio also rises when only those in Lippincolt's are considered who have received aljertives of praise. Nine-tenths of the persons named in this dictionary are given a passing notice by the editors and nothing rritical is saicl of their lives or their work beyond the barest record. About one-tenth reeeive such adjectives of praise as "celebrated," "illustrious," "eminent," "famous," " noted," etc.

A priori we may suppose that these represent an extra superior group as compared with the other nine-tenths. A posteriori the supposition is vorified, berause how alse can be explained the rise in the ratio for Massar husetts from 2.S to 3.8?" If this "adjective method" did not solect a superior group it would not raise the ratios, or in other words draw it further away from random hazard for which $\rho=1$. The more aceurately it seizes hold of the right persons and justly expresses real differences dependent upon natural causes the more it will raise this ratio. One can now see how it is possible in this way, and in similar ways, to artually test the validity of any method of selection. Its valuse depends, among other things, upon its ability to raise, or lower, a ratio in a proper degree, suitable to the case in hand, so that the ratios shall fit in, and harmonize with other ratios and other results.

If, for instance, the "space method," or the selecting the 234 men who have had the most space allotted to them in the dictionary, had not raised the Massachusetts ratio from 2.8 to any more than say 2.9 or 3.0 we might he justifiel in concluding that this method was inferior in aecuracy to the "adjeretive method." As it turns out, it raises the ratio to 3.6. So one susperts that the "space method" is not quite as aceurate as the "adjective method," since it does not raise the ratio as mueh though it deals with a smaller group. Of course one instance 
like this does not decide anything. I merely give it as an illustration of the ways in which historiometry may proceed.

I have also essayed a new method, namely selecting from Lippincott's a list composed of all those Americans whose biographies have been written and published in separate works. This constitutes a very small and presumably correspondingly select group, 129 in number. The ratio for Massachusetts is here seen to rise to 3.9 , practically the maximum. It should of course do so if the method is sound and is successful in seizing hold of the right men. This may prove a very accurate, practical, and rapid method of objectively listing great men in ancient or modern history, subject of course to such limitations and adjustments as special problems may require.

It can be seen that the general raising of the ratios is in no way dependent on the dictionary containing a large number of clergymen and writers. As a matter of fact, more than a third of the names are those of lawyers, bankers, merchants, politicians, government officials, soldiers, manufacturers, and engineers. Here by narrowing the list from 1266 to 232 and dealing with only a small group, we raise the ratio from 2.4 to 3 . It might be supposed by some that a greater attention is shown Massachusetts by writers of books, biographies, and histories because these writers live in the neighborhood. "Lippincott's Biographical Dictionary," however, is published in Philadelphia. Still it may be influenced by previous writings and earlier biographical dictionaries published in the neighborhood of Boston. If this is so to any appreciable extent then we should expect the ratio for Massachusetts to fall when present-day persons are graded by methods which have either nothing or little to do with historical traditions.

Two such methods of grading we fortunately possess in the compilations known as "Who's Who in America," and "American Men of Science." The ratios for Massachusetts do not fall. They dovetail in with the ratios from Lippincott's. IIence we may conclude that the differentiations found in Lippincolt's are not caused by unjust historical tradition and, furthermore, as far as one can see they are not in part caused by the same. "Who's Who in America" has been of ten used as an objective basis for sociologieal inquiries, but the eriticism has been made that this book gives undue inclusion of authors and professors. I think this eriticism is unjust. About forty per cent of the whole fall under the more practical types enumerated in Table I. These I have considered separately as far as the initials A, B, and C. They yield a ratio for Massachusetts of $\rho=2.5$, which is very elose to that for the whole book $\rho=2.6$. The same for Lippincolt's is $\rho=2.4$, which is not in its exact theoretical position, as it should be higher than that drawn from "Who's Who in America." It will, of 
course, be appreciated that the clearing up of small disagreements like this requires further analysis and the computation of the probable errors.

The ratios from Virginia I present in this abstract merely as a general contrast to Massachusetts. I prefer to make further statistical inquiries before attrmpting to interpret their meaning.

The third series of tests which illustrate the exactitude of historiometry are drawn lrom comparative stulles of the fame of Euripides and Sophocles. In Science, October 7, 1910, Mr. C. A. Browne called

TABLE II

\begin{tabular}{|c|c|c|c|c|c|c|}
\hline \multirow{3}{*}{ Acthorities } & \multicolumn{3}{|c|}{ SOPHOCLES } & \multicolumn{3}{|c|}{ EURIPIDES } \\
\hline & \multirow{2}{*}{$\begin{array}{l}\text { Sipace } \\
\text { Limper or } \\
\text { Pitges }\end{array}$} & \multicolumn{2}{|c|}{ Adjectives } & \multirow{2}{*}{$\begin{array}{l}\text { Space } \\
\text { lines or } \\
\text { l'ages }\end{array}$} & \multicolumn{2}{|c|}{ Adjectives } \\
\hline & & Pro & Con & & P'ro & Con \\
\hline 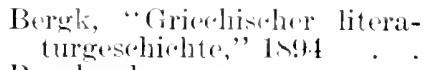 & $110 \mathrm{pp}$ & 128 & $2 S$ & $137 \mathrm{pp}$ & 100 & 64 \\
\hline Bernhardy. . . . . . . & $7+p)$ & 71 & 23 & $116 \mathrm{pl}$ & $10: 5$ & 97 \\
\hline croiset : . . . & $58 \mathrm{pp}$ & 115 & 13 & $71 \mathrm{ll}$ & $1: 32$ & 57 \\
\hline 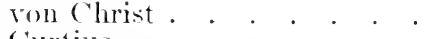 & $3+\mathrm{pp}$ & 46 & 3 & $40 \mathrm{pp}$ & 35 & 20 \\
\hline 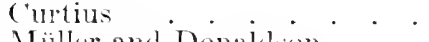 & 20015 & 25 & () & $73 \mathrm{l}$ & 36 & 20 \\
\hline Nü̈ller and Donalkson & $2.5 \mathrm{PP}$ & 31 & 3 & $30 \mathrm{Pp}$ & 17 & 14 \\
\hline 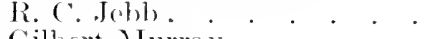 & $11 \mathrm{PP}$ & 16 & 0 & $16 \mathrm{PP}$ & 24 & 11 \\
\hline Gilhert IInrray . . . . & $19 \mathrm{PP}$ & 31 & 4 & 2s pp & 15 & $\begin{array}{l}6 \\
9\end{array}$ \\
\hline 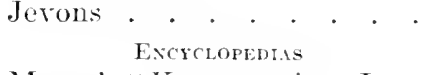 & $11 \mathrm{pp}$ & 14 & 0 & $13 \mathrm{pp}$ & 19 & 9 \\
\hline $\begin{array}{l}\text { Meyer"s" "Konversations Lox- } \\
\text { ition", }\end{array}$ & & 9 & 0 & $126 \mathrm{ls}$ & 8 & 2 \\
\hline Brokhaus" "Ixxikon" ... . & $112 \mathrm{ls}$ & 6 & 0 & $161 \mathrm{ls}$ & 2 & 1 \\
\hline $\begin{array}{l}\text { "La Grande linesolopédic", } \\
\text { "Encyelopedia Britannica," }\end{array}$ & $20 \mathrm{~s}$ ls & 27 & 1 & $17 \mathrm{~s} \mathrm{ls}$ & 5 & 1 \\
\hline 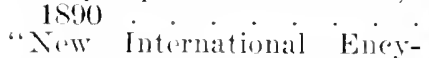 & $.50 \mathrm{ls}$ & 22 & 0 & $995 \mathrm{ls}$ & 10 & 4 \\
\hline Lippincott"s " "Biographical & $207 \mathrm{ls}$ & 10 & 2 & $1>1 \mathrm{ls}$ & 7 & 3 \\
\hline Dietionary," 14!2 . . . & 5218 & $s$ & 0 & $45 \mathrm{ls}$ & 6 & 0 \\
\hline
\end{tabular}

attention to the fart that sophoeles recerved the first prize from the Athenians twenty times, and Euripides only four times, while since their deaths varjous writors from Plato to Emerson have referred to and quoted Euripiles more than Sopluocles. Mr. Browne also shows that both Curtius and Grote, and biegraphical dictionaries, and encyclop:edias as well, allot more space to Euripides than they to to his elder rival. This seems to indicate that the opinion of the Athenians 
has been reversed by posterity, but the real explanation I have found to be otherwise.

It appears that the problem that Mr. Browne proposes is a very delicate one. These two great Greek dramatists stand in such an exalted position and so elose to one another, both being near the extreme range of human genius, that probably not two hundred individuals who have ever lived have exeeeded them in eminence. ${ }^{1}$ Therefore, eompared with all men of all historieal time, these two are almost merged in something like a point at the extreme end of a line. It is like sphitting and measuring the components of a binary star at a great distance. It would be no diseredit to any objective method of differentiation if it failed to give interpretable conclusions. As it is, it turns out that the problem presented is just within the limits of historiometric diserimination so that the figures yield uniformity and repetition warranting real conclusions.

I have extended Mr. Browne's list and have found eonfirmation of the statement that more space is deroted to Euripides than to Sophocles. This would leave the impression that Euripides is to-day frankly considered the greater of the two, which is not the impression that one gains by even a eursory reading of the printed matter so spaced. Furthermore, I am informed by John Williams White, Professor of Greek, Emeritus in Harvard University, that for the last hundred years the general estimate of scholars has placed Sophocles above Euripides. This is precisely the eonclusion which is obtained from the extraordinary character of some of the terms and sentences of eulogism which one finds applied to Sophocles. In these same authorities one never finds for Euripides anything like the following: "There has hardly been any poet whose works can be eompared with those of Sophocles for the universality and durability of their moral significance ... of all poets of antiquity Sophocles has penetrated most deeply in to the recesses of the luuman heart" (Müller and Donaldson). "He renders tragedy a perfect work of ideal art" (R. C. Jebh). Oceasionally the direct comparison is made and then Euripides suffers; for instance, as when Gilbert Murray says :-

"No wonder Sophocles won four times as many prizes as Euripides. ... Sophocles shows at times one high power which but few of the world's poets share with him ... in the second Edipus there is a certain depth of ealm feeling unfettered by any movement of mere intellect, which at times makes the subtlest and boldest work of Euripides seem 'young man's poetry' by comparison."

It can be easily seen that this general impression ean be checked up and is unfailingly expressed by each ratio of the adjeetives of praise

${ }^{1}$ Cf. J. McK. Cattell, The Popular Science Monthly, February, 1903, p. 359. 
(pro) against those of dispraise (con). For every single authority consulted the answer is the same, - the proportionate ratio favors Sophoeles. ${ }^{1}$

The "space method" fails here to give a verdict agreeing with modern and ancient opinion probably for special reasons peculiar to the case. More plays of Euripides are extant and there is more to be said in the way of adverse or qualifying criticism. It is not to be denied that the interest in Euripides is, and always has been, intense, perhaps greater than in Sophocles, but the position of the latter is more majestic and more sublime. The lexicons alone would have given this eonclusion in a few minutes' reading. All these facts, in connection with those taken from Lippincott's dictionary, indieate that the "adjective method" is a very delicate way of measuring small differenees if for any reason it is desirable to do so.

The questions here touched upon eoncern only the individuals, but I know from material as yet unpublished that the quantitative objective method can be applied to events as well as to persons. If its validity for the study of individuals ean be securely grounded, then its application to events will naturally follow and will be thereby the more easily and surcly established.

Space has permitted only a brief abstraet, but I think that enough has been given to prove that researches of this nature furnish harmony and order, intertwine and mutually support each other, form an organic structure, and are entitled to recognition among the exact scienees. It must he remembered that exactitude in seience is a relative term. Abstract mathematies may be exact, but no science of physieal measurement is really exact. Astronomy, which is usually thought of in this way, only gives an approach towards an ever expanding ideal. No two observers have cver quite agreed upon the latitude of the Greenwich observatory, and the last transit of Venus was, if I remember rightly, in comparison with the computed prediction, some eleven seconds off. All we ask is that the exactitude shall be sufficient for the practieal needs of the problem in hand.

I think it must be agreed that this first synthesis and coördination of isolated researehes presents a very encouraging picture. It indeed gives proof that a workable instrument has been obtained eapable not only of dealing with questions as intricate as human nature and its attributes, but actually at the same time demonstrating the essential validity of the historical data on which are based the percentile grades, ratios, correlations, or other superstructure. This latter conception is to me the most interesting side of the whole matter. It has usually

' In this part of the work I have had the assistance of Mr. A. A. Jenkins, of the Harvard Law School. 
been impossible to scientifically refute those critics who claim that the so-called facts of history are so uncertain and subject to so great an error and prejudice that it is unsafe to build conclusions upon them by statistical methods. They have not of course ever known that such was the case nor have they ever had any way of estimating how far the records of history, as they exist in standard works, encyclopædias, and biographical dictionaries, actually deviate from the absolute truth. It has been assumed, on the other hand, by those who have been engaged in grading historical characters, that the records represent a fair approximation towards the ideal truth. The human record which we call history stands somewhere between two extremes, somewhere between the quagmire of complete falsehood and heights of perfect truth. It is possible as we go on to appreciate, with closer and eloser accuracy, just what deviation from ideal truth any great set of historical records contains.

Such researches give promise of at last furnishing the long-sought correct method of penetrating the tangled and perplexing jungle known as philosophy of history. This domain of thought is to-day in poor esteem among those who, as historians of the modern school, seek in documentary sources to reconstruct the past around some central theme, some individual age or nation. No wonder these careful investigators have become disgusted with the a priori dogmatism, the partizan spirit, the free generalizations from half truths and the eternally conflicting conclusions. Historical philosophers, in their desire to explain everything at once, have been content to formulate theories, and then pick from the totality of history selected facts to support them. With methods highly subjective, and carrying a large personal equation they could not help but find exactly what they wished. The ways of inductive science may be slow at first, but even a small nucleus of collected and coördinated facts soon grows with astonishing rapidity ; and every objectively established piece of work makes it, with accelerated speed, that much easier to progress along lines of certainty and exactitude.

Frederick Adams Woods.

Massachusetts Institute of Technology. 



\section{INDEX}

Analysis of eorrelation tables, 245-279. Causation, historical, 32, 33, 36, 280Anthropo-geographieal interpretation, 20.

Anthropology, measurements of, 16-36. Appendix, explanation of, 9 .

Aragon, bibliography, 31 . correlation table, 241. grading, rulers and conditions, 324 . summarized history, $77-4)$.

A ristocraey of wealth, 2a0-304.

Austria, bibliography, 372 . correlation table, 243. grading, rulers and conditions, 373. summarized history, 161-17\%.

Authorities, 7, 9, 25.

Autonomie sehool, 20 .

Bias, vii, 22, 30, 275-276.

Bibliography, for Aragon, 65.

Austria, 161.

Castile, 65.

Denmark, 113.

England, 196.

Franee, 37.

Netherlands, 91 .

Portugal, 87.

Prussia, 151.

Russi:1, 139.

Seotlind, 1si.

Sweden, 123.

Turkey, 17s.

United Spatin, s1.

Bibliography of Historiometry, 404.

Bodin, 17.

Bossuet, 17.

Bravery, 5.

Breeder's view of history, 277

Brillianey, 5.

Buekle, 16, 19.

Castes, evolution of superior, 294-301.

Castile, bihliography, 31.

correlation table, $2+1$.

grading, rulers and conditions, 31 s.

summarized history, $65-76$. 303.

Causes, their assigument, 32-35.

Change in eonditions are sudden after monarch's death, 277 .

('haracteristies which win, 274 .

('hroniclers, 17, 276.

Cities, share of leading men, 27.

Civilization, its decline, 2.

determinants, 16.

early states of, 302 .

Coefficients, strain of, 24.

Comparisons, systematie, 3.

Complexity of history, 290 .

Comte, Aug., 18.

Conlitions, of C'ountry, 5.

of Rulers, 241.

influence of, $247-249$.

Correlation, agreement of, 23-27.

coeffirient, 245.

masking of, 11.

of gruding, 240 .

tibliles, 241-244.

('ountries studied, fourteen, 36 .

('our:ege, is.

Criticisms, mistaken, $25-26$.

('urve, showing distribution of intellectual qualities, 295.

Decline of nations, 295 .

Denmark, bibliography, 348. correlation table, 242 . grading. rulers and eonditions, 348 . summarized history, 113-1:2.

Descomlants, few left by inferior brimehes, 272 .

Deriation of correlations, 245 .

Differences, problems of, 290-294.

l)ogmatie opinion permissible, 1536.

Dognatic statements, 34.

Doulteful eases conceded, ix.

1)roysen, 19.

Duration of royal leadership, 294.

Dynastic factor, the, 2. 
Economic interpretation, 20.

Eminent men, distribution of, 407-417.

Encyclopædias, 9, 407-417.

England, bibliography, 394. correlation table, 244 . grading, rulers and conditions, 395 . summarized history, 196-239.

Epithets, characteristic, 8 .

Error, approxinate, etc., 23, 35 . constant, 275.

in data, 23,24 .

probable, 245 .

random, 275.

sourees of, 11, 12.

Evolution, 15.

False Bias, 275.

Farnam, H. W., The Economic Ctilization of History, 292.

Flint, History of the Philosophy of History, 19.

France, bibliography, 305. correlation table, 241. grading, rulers and conditions, 306 . summarized history, 37-64.

Galton, 21.

Gametes, 277-27s.

Gametie causes, 257. a priori view, 271-275. inherituner, 269-270. interpretation of history, 277 .

Genealogical method, viii.

General survey, 210-279.

Genetic view, 15, 277-279.

Genius, 259. 262, 274. 29s.

George William, a type, 2s1-2s9.

Geographieal interpretation, 20.

Goodne'ss, 5.

Grading kings, 4-14.

method, $24,407-417$.

topies used, 10 .

weakness in, 24.

Graphic ('urves to show class differences, $280-304$.

Great Elector, the, 24t-285.

Great Man view of history, 280-304.

Great men, importance as factors, 1-14.

Guizot, 19.

Hegel, 17.

Heredity, viii, 23 .

Historians, disagreements of, 7 . partisanship of, 15 .
Historiometry, an exact science, 407. central idea, 15-36.

bibliography of, 404 .

philosophy of, vii-x, 1-14, 15.

History, breeder's view of, 277 .

causation in, 280-303.

complexity of, 290 .

errors of, $\mathbf{x}$.

gametic interpretation, 277 .

need of new interpretation, 1-14.

philosophy of, 1-15.

printed statements of, 3 .

Historical estimates rarely reversed, 276.

Hohenzollerns, 281-289.

Ibn Khaldūn, 16.

Icleological interpretation, 20.

If: the postulation of, 287 .

Individualistic interpretation, 20.

Influence of individual monarchs, 1-14.

Intuiry, the limit of, 12.

Insinity, 259, 264.

Intellectual qualities, distribution, 295. curve of, 296.

traits, 5 .

International marriage of rulers, 255 .

Interpretation of the results, 240 .

Interreigns, 253-255.

Khaldūn, Ibn, 16.

Kings, classification of, 4.

Kulturgeschichte, 20 .

Leadership, duration of roval, 294.

Lehr, P. E., Études sur l'histoire, etc., 271.

Liberty, political, 10 .

Lists, compilation of, $27,28$.

Marriage of rulers, international, 255.

Mathematical priuciples in grading, 24.

Measurements, approximate nature of scientific, ix.

Measurements of anthropology and psychology, 15-36.

Mental, distribution, curve of, 297. superiority, 258-260.

traits, 5.

Method for collecting evidence, 1-14.

its chief ain, 20.

new one needed, 19.

of differences, 292.

threefold, 4. 
Minorities, 13, 14.

evidence from, 240-279.

Monarchs, an international breed, 13.

Montesquieu, 16, 17.

Moral traits, 5.

types, 269.

Nations, the life of, determinants, 16.

Natural selection, 273.

Netherlands, bibliography, 340 . correlation table, 242 . grading, rulers and conditions, 341 . summarized history, 91-112.

Non-royal leaders, 13.

Objective nature of the problem, 3 .

Objectivity and Induction, 35 .

Ottoman power, expansion of, 247-248.

Parallelism between rulcrs and conditions, 240-279.

Pedigrees, evidence from, 240-279.

Percentage and correlation cocfficient, 245.

Personal, characteristics, 274.

equation, the, 32 .

influence of statesmen, 13.

Personality, viii.

Philosophers of history, their failure, 15-36.

Philosophy of historiometry and history, 15.

Political interpretation, 20.

Portugal, bibliography, 332 . correlation table, 242. grading, rulers and conditions, 333 . summarized history, 87-90.

Precocity of royalty, 258-259.

Probability, degrees of, 291. measurement of, 287-288.

Problem stated, 1-14.

Prussia, as an example of causation, 280-304.

bibliography, 366 .

correlation table, 243.

grading, rulers and conditions, 367 . summarized history, 151-160.

Psychic categories, arbitrary, 5 .

Psychology, measurements of, 15-36.

Quantitative analysis, 21,22 . valuation, 20,21 .

Quetlet, 21.
Regencies, 13, 253-255.

Results, interpretation of, 240 .

Richard III, 30.

Rousseau, 17.

Royalty, natural ability of, 240-279.

Royalty and nobility, relative difference between, 2 .

characteristics of, 258-266.

compared with other classes, 257.

Rulers and conditions, 240.

Russia, bibliography, 358 .

correlation table, 243.

grading, rulers and conditions, 359 .

summarized history, 139-150.

Schlegel, F. von, 18.

Scope of the work, 1-14.

Scotland, bibliography, 388 .

correlation table, 244.

grading, rulers and conditions, 388 .

summarized history, 187-195.

Significance of Regencies and Minorities, 1-14.

Sociological school, the, 20.

Spain (United), bibliography, 318 .

correlation table, 241.

grading, rulers and conditions, 318 .

summarized history, $81-86$.

Standard works, value of, 21.

Struggle among scions of royal families, 274.

Stupidity, 5 .

Sultans, their maternal ancestry, 247.

Survival of fittest, 272 .

Sweden, bibliography, 353 .

correlation table, 242.

grading, rulers and conditions, 354 .

summarized history, 123-138.

Table I. Ruler and Conditions, 241244.

Table II. Cases and Sequences, 250.

Table III. Regencies, Minorities, and interreigns, 253.

Tables of correlation, 241. cases and sequences, 250 . conditions, 241-244.

regencies, minorities, 253.

rulers, 241, 266-268.

Tabular columns employed, 5,6 .

Tabulation, 241.

method, 27-29.

of cases, 250 .

politico-economic, 9-10. 
Tabulation - Continued. political movement, vii. regencies, 253-255.

Talents of royalty, 259-261.

Territorial outlines, 12.

Tests, quantitative, 3.

Traits which win, 27.4 .

Turgot, 19 .

Turkey, bibliography, 382 . correlation table, 243. grading, rulers and conditions, 383 . summarized history, 17 $\$-1>6$.
Variations, 240.

in rulers not caused by conditions, 251.

Vico, 17.

Weak kings, weak periods, 289.

Wickedness, 5 .

Woods, F. A., Scparating Heredity from Environment, 279.

Laws of Diminishing Environmental Influences, 279.

Younger sons of kings, 259. 


\section{By the HON. JAMES BRYCE}

The Holy Roman Empire

Rerised edition, cloth, $\$ v 0, \$ r .50$ net

"The ripe scholarship, the philosophic insight, and the judicial temperament of the distinguished author are revealed with increased vividness, and the treatise as it stands tu-day is more than ever an impressive illustration of literary evolution. That a prize composition should grow into such a monument of erudition is difficult to realize." - Outlook.

"This latest edition has taken into account fully the results of modern historical research. A concluding chapter ... on the new German Empire... a chronologieal table and three maps have also been added." - Review of Reviews.

\section{Studies in Contemporary Biography}

Cloth, Svo, \$3.0o net

"It is long since we have had occasion to welcome a collection of essays so attractive on the score both of subjects and of treatment as will be found in the volume entitled, "Studies in Contemporary Biography." " New York Sun.

"There still falls to our hand an occasional volume that is not romance, and yet is rudily and vital with the blool of life: such a une, among our newer books, is "Studies in Contemporary Biography." - Success.

\section{By B. ESTES HOWARD}

\section{The German Empire}

"Laboriously accurate and supported by excellent explanatory notes." Spectator.

By ERNEST F. HENDERSON, A.B. (Trinity), M.A. (Harvard), Ph.D. (Berlin).

Author of "A History of Germany in the Middle Ages," ete.

\section{A Short History of Germany}

Cloth, 8vo, \$2.50 net

"Mr. Ienderson's history proves that the modern chronicle of the development of a nation can be, and often is, even more interesting than the old-fashioned history, which was merely a collection of biographies of famous men and descriptions of dramatic events."- The Times, Washington.

\section{THE MACMILLAN COMPANY \\ Publishers 64-66 Fifth Avenue New York}


"A WORK UPON WHICH WE CAN UNRESERVEDLY CONGRATUlate THE AUTHOR AND HIS COUNTRY." - The Athencum, London.

\title{
The Government of England
}

\author{
BY A. LAWRENCE LOWELL \\ President of Harvard University
}

Formerly Professor of the Science of Government

Author of "Colonial Civil Service," etc.

Revised Edition with a New Chapter

In two volumes. Bound in the style of Bryce's "American Commonwealth." Cloth, 8vo, \$4 net

The New York Sun calls it: -

"The remarkable work which American readers, including even those who suppose themselves to be pretty well informed, will find indispensable . . ; it deserves an honored place in every public and private library in the American Republic." - M. W. H.

"Professor Lowell's book will be found by American readers to be the most complete and informing presentation of its subject that has ever fallen in their way. . . . There is no risk in saying that it is the most important and valuable study in government and politics which has been issued since James Bryce's 'American Commonwealth,' and perhaps also the greatest work of this character procluced by an American scholar." - Philadelphia Public Ledger.

"It is the crowning merit of the book that it is, like Mr. Bryce's, emphatically a reaclable work. It is not impossible that it will come to be recognized as the greatest work in this field that has ever been produced by an American scholar." - Pittsburg Post.

"The comprehensiveness and range of Mr. Lowell's work is one of the reasons for the unique place of his 'Government of England' - for its place in a class by itself, with no other books either by British or non-British authors to which it can be compared. Another reason is the insight, which characterizes it throughout, into the spirit in which Parliament and the other representative institutions of England are worked, and the accuracy which so generally characterizes definite statements; all contribute to make it of the highest permanent value to students of political science the world over." - EDward PorRITT in The Forum.

\section{THE MACMILLAN COMPANY \\ Publishers \\ 64-66 Fifth $\Delta$ venue \\ New York}




\section{HISTORY OF GERMAN CIVILIZATION}

\section{From the Brooklyn Eagle (N.Y.)}

Cloth, I2mo, \$2.0o net; by mail, \$2.I4

"No more interesting or careful study of any phase of European history has come from the press in years than the recent volume of Emst Richard's II istory of German Civilization. Without fear of overpraise we may place it in the same rank with that wonderful History of European Morals of Professor Lecky, and we are confident that when the present work becomes known, it will have as great a vogue among scholars as Lecky's had for years."

From the Boston Herald (Mass.)

"In some ways his book is a model on which all writing of history might be patterned. . . . There is a thoroughness about the book which is itself German. The sketch of Germanic origins shows the grip of an expert upon his subject. Dr. Richard writes as a German and at times writes enthusiastically. But he is no chauvinist, and his emphasis on the value of German ideas for world civilization rests on solid foundation. In placing that emphasis he covers the whole range of German achievement in literature and science, in law and in art. His book is itself a noteworthy contribution to the 'German ideals of truth, justice, and beauty.'"

From the Tribune (N.Y.)

"Dr. Richard's book is literally what he calls it, 'a survey.' What is more, it is a survey which admirably well weighs the relative importance of periods, and which makes a telling use of contrasts, of those amazingly pronounced alterations of development and retrogression that have marked the 'Kultur Geschichte' of the German people. The author is strictly impartial, notwithstanding his profound interest in his subject. Germany is none too sympathetically dealt with by foreign observers, students, and critics of the day. This work furnishes a welcome counterweight to their not always unprejudiced and well-considered strictures."

\section{From the New York Times' Review of Books}

"A useful and intcrcsting book. He draws a persuading, even a convincing portrait of a people strong in mind and will, active, dutiful, in many ways noble, in somc very attractive."

\section{From the Westminster Gazette (London)}

"He has succeeded in producing a general history of German civilization which is wholly admirable. . . . It is written in a clear and confident style. The English is as pure as anything which comes from Oxford."

\section{Translated from the Weserzeitung (Bremen, Germany)}

"Thus the book which holds the middle between scholarly investigation and popular representation proves itself inspiring and instructive also for us Germans."

\section{THE MACMILLAN COMPANY

Publishers 64-66 Fifth Avenue New York




\title{
Dictionary of National Biography
}

Edited by L. STEPHEN and Sir SIDNEY LEE

\author{
22 volumes Solit only in Sets Each rolume Sio \$f.25 net \\ Index and Eifitome, Sio, $\$ 6.25 \mathrm{nt}$ \\ Second Sufplement: Iol. I (.th-F.1 , sio, $\$ 7.25$ net

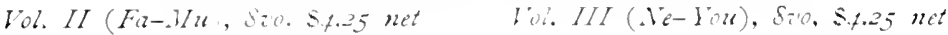

The "I)ictionary of National Biography," the most comprehensive and authoritative of all hiographical collections has come to be known as one of the ereat reference works of the modern world. It was designed to supply accurate and concise biographies of all moteworthy inbabitants of the british Empre exclusive of living presmet from the carliest hi-torical period to the present time, and there is no question that its am has been satisfactorily realized.

The province of the work embraces all lives likely to interest students of history, naval and military affairs, the progeres and alministration of colonies, philosephy, natural science, medicine, surecry, theolosy, literature, political economy, law, munic, art, and the drama.

\section{CAPABLE CONTRIBUTORS}

All the articles, whether short or long. have been prepared by specialists of literary experience in very varied branches of knowledere. The total number of contributors approbches, ;oo, and their labors preacent the latest results of biographical research. Many of the memoirs of kings and queens, of great statemen. generals, and admirals, enbody information derived from state Papers and on her authorities which have onty hereme accessible in very recent yars. Thus the bictionary supplies in the case of many distinguished names mere detailed and exart bugraphies than any that have previnsly appeared. Sut it has been the particular encleavor of the Edliturs to hestow as much, or even more patins on the far more numerous names of less willely arkmon lexlegel importance.

The Dictionary furnishes the mos exhantive, interesting, and varied picture to be found fi lingliah-sukekng life during more than ten centuries. The full number of pugen is over 30.500 . and the work centains more than 30,000 sepurate artives. The averase length of an artide is sightly less than one prage, but the spare has been so distributed as to arlmit many full and exhaustive, though concise momographs, sone of which will rank among standard biographic in English literature.

SOLD BY SUBSCRIPTION

\section{THE MACMILIAN COMPANY \\ Publishers \\ 64-66 Fifth Avenue \\ New York}




\section{VALUABLE BIOGRAPHIES IN BRIEF COMPASS}

\section{English Men of Action}

Campbell. By A. Forbes.

Clive. By C. P. Wirsos.

Cook, Capt. By SiR W. BEsANT.

Dampier. By W. C. Rrssel.

Drake. By J. Cokbetr.

Dundonald. By J. W. Fortescte.

Gordon, Gen. By SIR W. F. Butler.

Hastings. By SiR A. IYALI.

Havelock. By A. Fonis:.

Henry V. By A. W. CHuRcil.

Lawrence, Lord. By AReu. Temile.

Livingstone. By T. Ilcinls.
Cloth. ramo. Fach s.7 met

Monk, Gen. By J. Conbetr.

Montrose. By A. Morris.

Napier. By Sir W. F. Butlek.

Nelson. Hy J. K. LAvihtox.

Peterborough. By W. StkBbins.

Raleigh. By R. Ronn.

Rodney. By I). G. IIAnvar.

Smith, Capt. John. By A. G. Bradeey.

Strafford. ly II. I). TRAlli..

Warwick. By C. OMAN.

Wellington. By G. Hoorer.

Wolf. By A. J. BRADLlY.

\section{Twelve English Statesmen}

Oliver Cromwell. By F. IlARRISON. Elizabeth. By E. S. PEIsLY.

Edward I. By Professor T. F. Tut'T.

Henry II. By Mrs. J. R. GREeN.

Henty VII. By J. Garriner.

Peel. By J. R. Tutramili.

Pitt. By Lord Rosiberr.
C:th. rame. Eich $\$ .75$ net

Walpole. By JoHiN Mori,ey.

William the Conqueror. By F. A. FREEMAN.

William III. By II. D. Traili.

Cardinal Wolsey. By M. Crenthton.

Chatham. By Jurx Mukifs.

(Prefaring.)

Foreign Statesmen Series. Edited by Professor Bury, Trinity College,

Dublin.

Cavour. By Corntess (AEsAResCo.

Charles the Great. By T. IOngkis.

Cosimo de Medici. By. K. 1). Emakт. Joseph II. By J. F. BRicitr.

Maria Theresa. By J. F. BRight.

Mazarin. By A. Hassall.
Cloth. 12mo. Each volume $\$ .75$ net

Mirabeau. By P. F. Whllekt.

Philip II. By M. A. S. HUMF.

Philip Augustus. By R. H. HITton.

Richelieu. Iiy R. I,Onis.

William the silent. By F. HARRIson. 







1.3 .3 

